\title{
New Genotypes of Long and Thin Grain Rice and Technology for Production in Mexico: Michoacán State as an Example
}

\author{
Juan Carlos Álvarez-Hernández, \\ Luis Mario Tapia-Vargas and \\ Anselmo Hernández-Perez
}

Additional information is available at the end of the chapter

http://dx.doi.org/10.5772/intechopen.79152

\begin{abstract}
In Mexico, the national demand for rice exceeds four times the consumption of the grain produced internally, which has caused growing volumes of imported rice. Long and thintype rice is the one with the highest consumption. Faced with this problem, a strategy was implemented based on the evaluation, validation, and release of rice materials. Since Michoacán State is involved in rice production, evaluations have allowed the selection of materials, which has resulted in the current availability of a number of advanced experimental lines. Also, the technology that has traditionally been used in the cultivation had changed, so that continuous improvement programs have been developed represented by the system of cultivation in direct sowing in furrows and continuous irrigation. The new varieties do not require continuous flooding, which allows for a greater efficiency in the use of water and soil resources. Studies on rice nutrition in Mexico are still scarce, especially under irrigated conditions. The current has focused on the nitrogen fertilization of this crop since the exploration of the efficient management of soil nutrition is a vitally important issue. Other aspects integrated to the rice technology are the use of a low seed rate and weed management using a new generation of herbicides.
\end{abstract}

Keywords: elite lines, entire rice, genetic materials, Oryza sativa, rice genotypes, rice technologies, "Valley of Apatzingan" 


\section{Introduction}

Of small grain cereals, rice (Oryza sativa L.) is a crop of extreme importance in the world. In Mexico, this cereal occupies the fourth place among the most cultivated grains for food purposes, only below corn, beans, and wheat. According to the Ministry of Agriculture, Livestock, Rural Development, Fisheries and Food (SAGARPA, by its acronyms in Spanish), it is annually consumed on average 1.3 million tons. This shows that the national demand for rice exceeds four times the production in the country which has caused increasing volumes of rice import. It is important to mention that the long and thin type of rice is the most consumed in Mexico due to its better industrial quality and physical appearance of the grain than other rice types. Due to this, the country has been mainly dependent on imports, adding up to 800,000 tons of grain per year to satisfy the internal market. This situation has brought about dismantling of the "chain" rice, an activity that discourages domestic production; additionally, the said imports tend to grow up to $85 \%$ of national consumption [1].

In this situation, the Mexican Rice Council A.C. delivered materials from the Latin American Irrigation Rice Fund (FLAR) to the National Institute of Forestry, Agriculture and Livestock Research (INIFAP, by its acronyms in Spanish), which were the support for undertaking studies oriented toward evaluation, validation, and release of improved rice varieties in Mexico. Both the experimental trials and the validation trials were conducted in the rice-producing areas of the country under experimental designs and applying the methodology of stability parameters, evaluating their response to the different environments and conditions of development [2-4]. The process consisted of the selection of genotypes with desired agronomic characteristics, derived from the crossing of materials in the field. For the last 10 years, INIFAP has been doing an arduous and constant work, so, to date, there are stable varieties of long grain and thin rice. Despite the efforts, not enough long grain rice varieties adapted to the different agroecological conditions are available in the country [5]. However, in some regions, advanced experimental lines have been selected, including the release of the following two varieties with long and thin grain properties: FL05392-3P-12-2P-2P-M registered as INIFLAR R [6] and FL04621-2P-1-3P-3P-M registered as INIFLAR RT [7], which is becoming an alternative to the Milagro Filipino variety that has been intensively and extensively cultivated, despite the remarkable loss of its purity [8]. These outstanding genetic materials are superior to the conventional variety in grain yield, industrial quality, in addition to the characteristics of the long and thin grain type.

It is worth mentioning that one of the aspects that have defined the preference of the consumer is the culinary quality of the rice, also by the industrialists, the industrial quality of the grain is a parameter to be taken into account. Being the state of Michoacán that participates in the production of rice, the evaluations of these lines have allowed to select materials, which has currently resulted in y having a number of advanced experimental lines. Also, the technology that is traditionally used in cultivation has had substantial changes. Therefore, continuous improvement programs have been developed, represented by the direct sowing system in "grooves" and irrigations supplementary, taking into account that as in all crops, water is basic for the rice plant to complete its functions unlike other species; also, water is an essential 
means for rice to develop and reduce competition of weeds and other plants antagonistic to rice; however, currently, the shortage of water is the main problem for humanity, but the new varieties do not require continuous flooding, which allows to have a greater efficiency in the use of water and a better use of the resources. On the other hand, studies on nutrition in rice cultivation are still scarce, especially under irrigation conditions. These have focused on nitrogen fertilization. Therefore, the exploration of the efficient management of nutrition is a subject of vital importance. Other aspects integrated to the technological "package" of rice are the use of less quantity of seed per area and the management of weeds through new-generation herbicides.

Under these circumstances, it is necessary to promote the production of thin and long grain rice to reduce dependence on the import in order to maintain the balance of the industry in Mexico. As already noted, the strategy for reversing this situation has been the release of highyield potential rice varieties with the high milling and culinary qualities which satisfies the demand of the industry and consumers.

\section{Importance of rice cultivation}

Rice is sown in the agroclimatic regions of the humid, sub-humid, and dry tropics of the country, which are differentiated by their temperature, precipitation, and by the sources of

\begin{tabular}{llllll}
\hline States & $\begin{array}{l}\text { Cultivated } \\
\text { area (ha) }\end{array}$ & $\begin{array}{l}\text { Grain yield } \\
\left(\mathbf{t} \cdot \mathbf{h a}^{-\mathbf{1}} \mathbf{)}\right.\end{array}$ & Total production (t) & $\begin{array}{l}\text { Average price } \\
\left(\mathbf{U S D ~ t}^{-\mathbf{1}}\right)\end{array}$ & $\begin{array}{l}\text { Total value } \\
\text { (USD) }\end{array}$ \\
\hline Campeche & 9963.5 & 4.9 & $49,479.9$ & 209.2 & $10,354,885.6$ \\
Chiapas & 537.0 & 1.8 & 1004.8 & 272.2 & $273,597.4$ \\
Colima & 3330.0 & 5.1 & $17,252.8$ & 236.6 & $4,082,699.9$ \\
Guerrero & 390.8 & 6.2 & 2443.8 & 324.4 & $792,992.4$ \\
Jalisco & 2998.4 & 5.3 & $15,907.2$ & 246.3 & $3,917,913.5$ \\
Mexico & 68.0 & 5.4 & 372.6 & 329.6 & $122,837.7$ \\
Michoacán & 3384.0 & 8.7 & $29,454.2$ & 240.4 & $7,082,376.0$ \\
Morelos & 1323.4 & 10.1 & $13,392.8$ & 289.6 & $3,879,593.4$ \\
Nayarit & $10,769.5$ & 6.4 & $69,279.9$ & 239.8 & $16,614,546.8$ \\
Oaxaca & 18.0 & 2.8 & 50.4 & 262.5 & $13,230.0$ \\
Tabasco & 1621.5 & 7.1 & $11,548.8$ & 207.2 & $2,393,171.2$ \\
Tamaulipas & 2738.5 & 6.1 & $16,886.1$ & 250.0 & $4,221,530.0$ \\
Veracruz & 4269.0 & 6.3 & $26,969.4$ & 268.4 & $7,238,917.9$ \\
Total & $41,411.8$ & - & $254,043.2$ & - & $60,988,324.2$ \\
\hline
\end{tabular}

Table 1. The area of cultivation, production, and value of rice in 2016 in selected states of Mexico [9]. 


\begin{tabular}{|c|c|c|c|c|}
\hline \multirow[t]{2}{*}{ Year } & \multicolumn{3}{|l|}{ Michoacán State } & \multirow{2}{*}{$\begin{array}{l}\text { Mexico } \\
\text { Area cultivated (ha) }\end{array}$} \\
\hline & Area cultivated (ha) & Total production $(t)$ & Grain yield $\left(t \cdot h a^{-1}\right)$ & \\
\hline 2016 & 3384.0 & $29,454.2$ & 8.7 & $41,411.8$ \\
\hline 2015 & 3942.0 & $33,260.5$ & 8.4 & $40,637.5$ \\
\hline 2014 & 4498.5 & $39,500.6$ & 8.7 & $40,642.3$ \\
\hline 2013 & 2510.9 & $22,933.9$ & 9.1 & $33,137.4$ \\
\hline 2012 & 3894.0 & $35,528.2$ & 9.1 & $31,795.2$ \\
\hline 2011 & 2792.5 & $25,465.1$ & 9.1 & $34,037.4$ \\
\hline 2010 & 3470.0 & $31,530.3$ & 9.0 & $41,747.7$ \\
\hline 2009 & 5658.0 & $48,571.2$ & 8.5 & $54,230.4$ \\
\hline 2008 & 4108.5 & $29,953.3$ & 7.2 & $50,285.6$ \\
\hline 2007 & 3165.5 & $29,190.0$ & 9.2 & $70,948.7$ \\
\hline 2006 & 4641.7 & $42,183.1$ & 9.0 & $70,469.6$ \\
\hline 2005 & 5424.7 & $49,529.0$ & 9.1 & $57,479.2$ \\
\hline 2004 & 4148.5 & $35,507.6$ & 8.5 & $62,389.8$ \\
\hline 2003 & 4598.0 & $37,505.0$ & 8.1 & $60,043.6$ \\
\hline 2002 & 2981.8 & $23,699.2$ & 7.9 & $50,457.2$ \\
\hline 2001 & 3858.0 & $29,634.9$ & 7.6 & $53,231.7$ \\
\hline 2000 & 4999.0 & $34,384.0$ & 6.8 & $84,068.9$ \\
\hline
\end{tabular}

Table 2. The trend in rice area of cultivation, production, and grain yield in the state of Michoacán, Mexico from 2000 to 2016 [9].

water supply to satisfy the water needs of the crop; although they are contrasting, the rice plant adapts to different soil, water, and climate conditions.

In 2016, the total harvested area of rice in Mexico exceeded 41,000 hectares, where 13 states participate in national production (Table 1); particularly the state of Michoacán is positioned in the fourth place with 3384 hectares, it is preceded by the states of Nayarit with 10,769 hectares, Campeche with 9963 hectares, and Veracruz with 4269 hectares [9]; however, in terms grain yield, Michoacán has the second place with 8.7 tons per hectare, only preceded by the state of Morelos with 10.1 tons per hectare. In the same year, the total value of the national rice production was USD 60, 988,324.2 (Table 1).

In a historical record, during the period from the year 2000 to the year 2016, in the state of Michoacán, the area under rice cultivation has been moderately stable since on average they have been 4000 hectares. However, during the same period, the trend in the area under rice cultivation at the national level showed different picture where it witnessed a substantial decrease from 84,000 ha in the year 2000 to only 41,000 ha in the year 2016 (Table 2). Although this $50 \%$ reduction in the area under rice cultivation was observed in just 16 years at the national level, the reduction for the state of Michoacán was only 32\% (from 4999 to 3384 ha). 


\begin{tabular}{|c|c|c|c|c|c|}
\hline Municipality & $\begin{array}{l}\text { Area } \\
\text { cultivated (ha) }\end{array}$ & $\begin{array}{l}\text { Grain yield } \\
\left(\text { ton } \cdot \mathrm{ha}^{-1}\right)\end{array}$ & $\begin{array}{l}\text { Total production } \\
\text { (ton) }\end{array}$ & $\begin{array}{l}\text { Average price } \\
\left(\mathrm{USD}^{-1}\right)\end{array}$ & Value USD \\
\hline Apatzingán & 26.0 & 8.5 & 222.3 & 237.5 & $52,796.2$ \\
\hline Gabriel Zamora & 2068.0 & 8.7 & $18,052.6$ & 241.1 & $4,352,831.6$ \\
\hline Múgica & 7.0 & 8.6 & 60.2 & 240.6 & $14,502.4$ \\
\hline Nuevo Urecho & 48.0 & 8.6 & 415.2 & 240.6 & $99,907.5$ \\
\hline Parácuaro & 366.0 & 8.7 & 3207.0 & 239.7 & $768,933.1$ \\
\hline Tepalcatepec & 869.0 & 8.6 & 7496.9 & 239.2 & $1,793,403.7$ \\
\hline Total & 3384.0 & - & $29,454.2$ & - & $7,082,376.0$ \\
\hline
\end{tabular}

Table 3. The area under cultivation, total production, and total value of rice grown in six municipalities in the state of Michoacán, Mexico [9].

Meanwhile, the municipal structure of the state of Michoacán that participates in the production of rice cultivation is shown in Table 3, all corresponding to the name "Valley of Apatzingán", it is a hot climate region. Thus, the municipalities of Gabriel Zamora, Tepalcatepec, and Parácuaro, devoted large areas under rice cultivation. These large areas under rice cultivation in these three municipalities also reflected in high production and economic return.

\section{Research on long and thin grain rice in Michoacán State, Mexico}

In the state of Michoacán, the Tepalcatepec basin, better known as the "Valley of Apatzingán" or the "tierra caliente," is a region full of contrasts, with a biodiversity that gives origin to different production systems which favors the establishment of different crops, citrus fruits currently predominate; however, as has happened in other places exploited under agricultural activity, the region has been affected by the production system of monoculture type and the indiscriminate use of agrochemicals, which has caused resistance of pests and pathogens, hence difficult to control by the conventional systems.

For the selection of new varieties of rice, the synergy between INIFAP and FLAR allowed the consolidation of this end, where the components of the yield included preliminary tests and national experiments in the different rice regions. It should be noted that the studies focused on the type of grain that determines the preference of the consumer and that also meets with milling, culinary, and nutritional qualities [5], as well as the characterization of phenotypic diversity using agro-morphological traits [10]. Consequently, it is important to follow up on advanced materials, in order to increase the supply and availability of seed. Particularly, the rice cultivation in Michoacán is cultivated in two production cycles that are differentiated mainly by their rainfall regimes and water supply sources to meet their water needs, which are very high given the physiology of the plant. The sowing dates are based on those recommended by the SAGARAPA for the spring-summer productive cycles (June 1 to July 31) and autumn-winter (January 1 to February 15) [11]. The autumn-winter cycle is when there are 
water deficits due to the demand of water resources for other crops like fruit trees and vegetables; however, in the spring-summer cycle, these problems do not occur due to the rainy season. According to the climatic classification of Köppen [12], the study area is located in a climate Bs1 (h') w (W) corresponding to the group of semi-dry warm climates (the wettest of the semi-dry warm climates), with rains in summer; the annual average, minimum, and maximum temperatures are of 28,20 and $37.7^{\circ} \mathrm{C}$, respectively; the annual average, minimum, and maximum precipitation are of 834,500 and $972.8 \mathrm{~mm}$, respectively. The type of soil is grouped in the vertisols "pelic" (clayey) $[13,14]$. As for the vegetation, it is represented by the primary types of low deciduous forest, secondary stages of natural succession (different degrees of regeneration after elimination) and bearing shrubby from 4 to $8 \mathrm{~m}$, and arboreal from 8 to $12 \mathrm{~m}$ in height $[15,16]$.

Michoacán State contributes with $11.6 \%$ of the national rice production; the advances in the evaluations of these lines have allowed to select promissory materials in substitution of the conventional variety. Based on the above information, the overall objective of this work was to evaluate advanced lines of long and thin grain rice compared with the conventional material under different production cycles and environmental conditions in Michoacán State in Mexico. Therefore, through the selection of promising materials obtained from these trials and through the establishment of validation trials under irrigation conditions, different materials of long and thin grain rice were evaluated and compared with conventional material for the two productive cycles [11].

\subsection{Methodology used in the different evaluations of rice genotypes}

The different evaluations were formed for the genotypes shown in Table 4, where experiments 1 and 2 (E1, E2) were made up of 13 and 14 genotypes [17, 18], respectively, and the validation trials 1, 2, and 3 (V1, V2, V3) were formed by 3, 7, and 3 genotypes [19-21], respectively.

In general, the soil preparation of the experimental trials consisted of basic mechanized work of fallow, plow, and level. In addition, small furrows of $0.2 \mathrm{~m}$ were marked between one and another, and the sowing of the seed was done at the seed rate of $80 \mathrm{~kg} \cdot \mathrm{ha}^{-1}$. Other agronomic practices consisted of irrigation every 5 and 8 days depending on the availability of water, control of weeds using selective pre- and post-emergent herbicides [22], fertilization in two stages (at approximately 20 days after the emergence and at the appearance of floral primordium), and application of fungicides. The experimental design used was Randomized Complete Block where the size of each experimental plot was $200 \mathrm{~m}^{2}$, and the experimental unit for productivity was formed by four blocks of one linear meter each one and 20 plants for the phenological aspects.

Different sets of data were recorded for the experiments and validation trials. For experiment 1 , the number of spikes per panicle, 1000 whole grain weight, 1000 polished grain weight grain yield, and days to harvest were recorded, while for experiment 2, plant height, spike length, number of grains per spike, grain yield, and 1000 polished grain weight were quantified. On the other hand, parameters measured for the validation trial 1 were plant height, 1000 whole grain weight, number of spikes per panicle, spike length, and grain yield while for validation 


\begin{tabular}{|c|c|c|c|}
\hline Tested rice lines & Common name & Genotype & Origin \\
\hline E1 & FL04582 & FL04582-5P-6-2P-3P-M & $\begin{array}{l}\text { VF (nursery FLAR)-2005 (year of } \\
\text { release) }\end{array}$ \\
\hline $\mathrm{E} 1, \mathrm{E} 2, \mathrm{~V} 1, \mathrm{~V} 2$ & $\begin{array}{l}\text { FL04621 } \\
\text { (INIFLAR RT) }\end{array}$ & FL04621-2P-1-3P-3P-M & VF-2005 \\
\hline E1 & FL04674 & FL04674-3P-8-3P-2P-M & VF-2005 \\
\hline E1 & FL04676 & FL04676-3P-4-1P-2P-M & VF-2005 \\
\hline E1 & FL04835 & FL04835-19P-9-3P-1P-M & VF-2005 \\
\hline E1, V2 & FL04867 (Marfil) & FL04867-2P-7-3P-3P-M & VF-2005 \\
\hline V2, V3 & $\begin{array}{l}\text { FL04952 } \\
\text { (Lombardia) }\end{array}$ & FL04952-1P-5-1P-1P-M & Santa Rosa, Colombia \\
\hline E1, E2, V1 & $\begin{array}{l}\text { FL05392 } \\
\text { (INIFLAR R) }\end{array}$ & FL05392-3P-12-2P-2P-M & VF-2006 \\
\hline E1 & FL05509 & FL05509-15P-1-2-3P-M & VF-2006 \\
\hline E1 & FL05598 & FL05598-5P-3-1P-1P-M & VF-2006 \\
\hline E1, V1 & FL05601 & FL05601-6P-2-2P-2P-M & VF-2007 \\
\hline E1 & FL05655 & FL05655-3P-4-2P-2P-M & VF-2006 \\
\hline E2 & FL06564 & FL06564-3P-1-4P-M & Santa Rosa, Colombia \\
\hline E2 & FL06580 & FL06580-3P-6-2P-M & Santa Rosa, Colombia \\
\hline E2 & FL06609 & FL06609-11P-12-4P-M & Santa Rosa, Colombia \\
\hline E2 & FL06624 & FL06624-4P-4-2P-M & Santa Rosa, Colombia \\
\hline E2 & FL06625 & FL06625-3P-5-1P-M & Santa Rosa, Colombia \\
\hline E2 & FL06646 & FL06646-10P-7-2P-M & Santa Rosa, Colombia \\
\hline E2 & FL06679 & FL06679-3P-5-3P-M & Santa Rosa, Colombia \\
\hline E2 & FL06689 & FL06689-1P-2-1P-M & VF-2007 \\
\hline V2 & FL06747 & FL06747-4P-10-5P-3P-M & Santa Rosa, Colombia \\
\hline E2 & FL07162 & FL07162-7P-3-3P-3P-M & VF-2008 \\
\hline E2 & FL07562 & FL07562-7P-3-3P-2P-M & VF-2008 \\
\hline $\mathrm{E} 2, \mathrm{~V} 2, \mathrm{~V} 3$ & FL08224 & FL08224-3P-2-1P-3P-M & VF-2009 \\
\hline E1 & Tomatlán A-97 & IR10781-75-3-2-2-0PZ-COMP1 & Triple crosses: Sinaloa A80/ITA 231//IR8 \\
\hline E2 & Aztecas & C109Cu83-5MCu-11Cu-5Cu-1Cu-1Cu & Triple crosses: Sinaloa A80/ITA 231//IR8 \\
\hline $\mathrm{E} 1, \mathrm{~V} 1, \mathrm{~V} 2, \mathrm{~V} 3$ & Milagro Filipino & IR8-288-3 & IRRI of Filipinas \\
\hline
\end{tabular}

Table 4. Rice lines investigated in Michoacán, Mexico, indicating their origin and genotypes.

trial 2 were plant height, length of the spike, number of spikes per panicle, number of tillers, 1000 whole grain weight, and grain yield. In addition, the occurrence of phenological events was recorded at the time of more than $50 \%$ of the plants. For validation trial 3 , only plant height and grain yield were recorded. The data were analyzed using the statistical software SAS Institute package [23], through analysis of variance and comparison of means by Tukey test. 


\subsection{Results of the different evaluations of rice genotypes}

Experiment 1 was developed in the municipality of Gabriel Zamora, Michoacán, Mexico, as shown in Table 5, with the exception of 1000 polished grain weight; the other parameters showed significant differences among the materials evaluated. In this case, it is important to highlight the performance of five materials (FL04621, FL04674, FL04674, FL05655, and FL05601) with a grain yield above $9 \mathrm{t} \cdot \mathrm{ha}^{-1}$, surpassing the other materials including Milagro Filipino (Table 5).

Regarding experiment 2 developed in the municipality of Parácuaro, Michoacán, Mexico, plant height, spike length, number of grains per spike, and 1000 polished grain weight did not show significant differences while grain yield showed significant differences where materials such as FL06689 and FL05392 gave a grain yield more than 11 tha ${ }^{-1}$ (Table 6). Also, it should be mentioned that based on results from experiments, promising materials for validation trials were selected.

From the three genotypes selected for the validation trial 1, the analysis of variance showed significant differences only for plant height and the number of spikes per panicle (Table 7) where genotype INIFLAR RT had a significantly higher plant height than the other two genotypes. On the other hand, the three genotypes did not have significant differences for 1000 whole grain weight, spike length, and grain yield (Table 7). The grain yield for the three genotypes slightly exceeded the regional average reported between 8000 and $8500 \mathrm{~kg} \cdot \mathrm{ha}^{-1}$ [9]. It should be noted that the validation trial 1 was carried out in the autumn-winter cycle and that included its sowing since the end of 2014 and developed in the first months of 2015 under

\begin{tabular}{llllll}
\hline Genotype & $\begin{array}{l}\text { Number of spikes per } \\
\text { panicle }\end{array}$ & $\begin{array}{l}\text { 1000 whole grain } \\
\text { weight (g) }\end{array}$ & $\begin{array}{l}\text { Grain yield } \\
\left(\mathbf{t} \cdot \mathbf{h a}^{-\mathbf{1}} \text { ) }\right.\end{array}$ & $\begin{array}{l}\mathbf{1 0 0 0} \text { polished grain } \\
\text { weight (g) }\end{array}$ & $\begin{array}{l}\text { Days to } \\
\text { harvest }\end{array}$ \\
\hline FL04835 & $12.8 \mathrm{ab}$ & $24 \mathrm{ab}$ & $8 \mathrm{ab}$ & 20.44 & $118.8 \mathrm{de}$ \\
\hline FL05598 & $13.8 \mathrm{ab}$ & $25 \mathrm{ab}$ & $5.1 \mathrm{ab}$ & 19.62 & $132 \mathrm{a}$ \\
\hline FL04582 & $11 \mathrm{~b}$ & $22 \mathrm{ab}$ & $7.4 \mathrm{ab}$ & 22.01 & $122.3 \mathrm{bcde}$ \\
FL05509 & $14.5 \mathrm{a}$ & $19 \mathrm{~b}$ & $6.9 \mathrm{ab}$ & 20 & $118.8 \mathrm{de}$ \\
Tomatlán A-97 & $13.3 \mathrm{ab}$ & $25 \mathrm{ab}$ & $8.6 \mathrm{a}$ & 20.43 & $120.8 \mathrm{cde}$ \\
FL04867 & $12.3 \mathrm{ab}$ & $27 \mathrm{a}$ & $8.6 \mathrm{a}$ & 19.83 & $130.5 \mathrm{ab}$ \\
FL05392 & $12.5 \mathrm{ab}$ & $26 \mathrm{a}$ & $8 \mathrm{ab}$ & 21.24 & $119.5 \mathrm{de}$ \\
FL04621 & $13 \mathrm{ab}$ & $26 \mathrm{a}$ & $9.1 \mathrm{a}$ & 21.76 & $126 \mathrm{abcd}$ \\
FL04676 & $13.8 \mathrm{ab}$ & $23 \mathrm{ab}$ & $7.4 \mathrm{ab}$ & 19.58 & $119 \mathrm{de}$ \\
FL04674 & $13.5 \mathrm{ab}$ & $24 \mathrm{ab}$ & $9.1 \mathrm{a}$ & 19.88 & $122.5 \mathrm{bcde}$ \\
FL05655 & $14.3 \mathrm{a}$ & $26 \mathrm{a}$ & $9.1 \mathrm{a}$ & 23.79 & $122 \mathrm{bcde}$ \\
FL05601 & $12.3 \mathrm{ab}$ & $23 \mathrm{ab}$ & $9.1 \mathrm{a}$ & 19.91 & $129 \mathrm{abc}$ \\
Milagro Filipino & $13.3 \mathrm{ab}$ & $24 \mathrm{ab}$ & $3.4 \mathrm{~b}$ & 20.49 & $116.7 \mathrm{e}$ \\
\hline
\end{tabular}

Table 5. Results of experiment 1 of rice genotypes in the municipality of Gabriel Zamora, Michoacán, Mexico, during spring-summer cycle 2010 [18]. 


\begin{tabular}{|c|c|c|c|c|c|}
\hline Genotype & Plant height $(\mathrm{cm})$ & Spike length $(\mathrm{cm})$ & Number of grains per spike & $\begin{array}{l}\text { Grain yield } \\
\left(t \cdot h a^{-1}\right)\end{array}$ & $\begin{array}{l}1000 \text { polished } \\
\text { grain weight }(\mathrm{g})\end{array}$ \\
\hline FL07562 & 60.66 & 25.16 & 20.2 & $7.92 \mathrm{~cd}$ & 22.45 \\
\hline FL07162 & 60 & 24.16 & 19.7 & $7.88 \mathrm{~cd}$ & 20.92 \\
\hline FL08224 & 68.33 & 24.5 & 19.03 & $9.38 \mathrm{abc}$ & 21.73 \\
\hline FL06564 & 73 & 23.83 & 23.03 & $9.32 \mathrm{abcd}$ & 22.92 \\
\hline FL06580 & 57.66 & 23.06 & 24.5 & $8.73 \mathrm{bcd}$ & 22 \\
\hline FL06609 & 66.66 & 23.73 & 23.56 & $8.17 \mathrm{bcd}$ & 20.54 \\
\hline FL06624 & 70 & 25.56 & 19.53 & $5.28 \mathrm{c}$ & 21.41 \\
\hline FL06646 & 70.66 & 24.73 & 21.13 & $12.16 \mathrm{ab}$ & 21.09 \\
\hline FL06679 & 64.33 & 25.9 & 23.4 & $10.75 \mathrm{abc}$ & 19.64 \\
\hline FL06689 & 66.66 & 26.9 & 20.13 & $9.42 \mathrm{abc}$ & 24.09 \\
\hline FL06625 & 67.33 & 25.33 & 19.9 & $8.54 \mathrm{bcd}$ & 20.35 \\
\hline FL05392 & 73 & 26.33 & 26.26 & $11.22 \mathrm{abc}$ & 22.12 \\
\hline FL04621 & 69.66 & 25.16 & 22.03 & $10.51 \mathrm{abc}$ & 28.49 \\
\hline Aztecas & 63.33 & 25.33 & 21.66 & $12.98 \mathrm{a}$ & 24.94 \\
\hline
\end{tabular}

Table 6. Results of experiment 2 of rice genotypes in the municipality of Paracuaro, Michoacán, Mexico, during springsummer cycle 2014 [17].

\begin{tabular}{llllll}
\hline Genotype & $\begin{array}{l}\text { Plant height } \\
(\mathbf{c m})\end{array}$ & $\begin{array}{l}\mathbf{1 0 0 0} \text { whole grain } \\
\text { weight } \mathbf{( g )}\end{array}$ & $\begin{array}{l}\text { Number of spikes per } \\
\text { panicle }\end{array}$ & $\begin{array}{l}\text { Spike length } \\
(\mathbf{c m})\end{array}$ & $\begin{array}{l}\text { Grain yield } \\
\left(\mathbf{t} \cdot \mathbf{h a}^{-\mathbf{1}}\right)\end{array}$ \\
\hline INIFLAR RT & $71.10 \mathrm{a}$ & 25.99 & $11.50 \mathrm{~b}$ & 25.10 & 8 \\
FL05601 & $66.8 \mathrm{ab}$ & 26.02 & $17.20 \mathrm{a}$ & 23.30 & 8.8 \\
Milagro Filipino & $63.00 \mathrm{~b}$ & 26.00 & $14.00 \mathrm{~b}$ & 26.10 & 8.5 \\
\hline
\end{tabular}

Table 7. Results of validation trial 1 of three rice genotypes in the municipality of Paracuaro Michoacán, Mexico, in autumn-winter cycle 2014-2015 [24].

the condition of irrigation, so unlike the FL05601 treatment, the material INIFLAR RT and Milagro Filipino showed a similar pattern in the number of spikes per panicle and the length of the spike, even in the yield. It is important to note that genotype INFLAR RT was selected for its performance under both irrigated and rainfed conditions [7], but it thrives best in the springsummer cycle, since it is when the rainy season coincides. Due to its productive capacity and establishment period, Milagro Filipino presented a normal yield, in addition to its loss of purity and mixing with other varieties, considering a selection [8] in the process of degeneration.

In the validation trial 2, the analysis of variance showed significant differences in all quantified parameters (Table 8). Plant height and spike length values for genotypes FL06747 and FL08224 were higher than those of INFLAR R and INIFLAR RT. This trend was similar for spikes per panicle, number of tillers, and 1000 whole grain weight, except for genotypes Milagro Filipino, FL06747, and FL08224 where similar results were obtained. Genotypes with a high grain yield 
were FL06747, INIFLAR R, and Lombardia, while the other genotypes also recorded a reasonable amount of yield surpassing the conventional variety (Table 8). As occurred in validation trial 1, validation trial 2 was also established under the conditions of the municipality of Parácuaro, Michoacán, Mexico, and these results corroborate the performance of long and thin grain rice genotypes in order to produce adequate amount during the spring-summer production cycle, also surpassed Milagro Filipino, observing that the characterization of these materials gives distinguishable elements that allow the propitious election, attributed to phenotypic diversity or traits morphological [10]. In this study, plant height ranged from 69 to $88 \mathrm{~cm}$ (Table 8), while in earlier study involving advanced rice lines, a height of $104 \mathrm{~cm}$ was reported [25], although the excessive increase in height is associated with problems of lodging or falling of the stalk on the ground. One quality of Milagro Filipino variety was its reduced plant height due to which no lodging was observed. Therefore, a desired feature of these materials from long and thin grain represents a rice with semi-dwarf or compact stature. On the other hand, spike length, spikes per panicle, and grain weight as well as number of tillers influenced the grain yield. The number of tillers per plant obtained in the current study was similar to the earlier study which reported an average of 13 tillers per plant from advanced rice lines [25]. Even though the stock trends in the components orientate to certain yield, this may vary; treatments FL06747, INIFLAR R, and Lombardia showed the highest yields (Table 8) and not necessarily related to grain weight and other components, so that probably could have other factors that influenced the response of the yield-like pathogens [26], loss of grain or empty grains. Despite this, the yields are acceptable and coincide with other reports [7, 27, 28].

Figure 1 shows the time for different phenological events starting from flowering to harvest maturity. Flowering occurred between 74 and 76 days for most varieties, with the exception of INIFLAR RT and Milagro Filipino which flowered after 80 days. The time for successive growth stages of maturity at "milky," "mass," and "harvest" of these varieties followed similar trend to the flowering where early flowering types were also early maturing and late flowering were late maturing. In the face of increasingly unstable climatic changes, an important characteristic that is valued quantitatively and qualitatively is the precocity of the materials, which has to do with the advancement of harvests, but without losing yield or quality; as could be

\begin{tabular}{lllllll}
\hline Treatments & $\begin{array}{l}\text { Plant } \\
\text { height } \mathbf{( c m )}\end{array}$ & $\begin{array}{l}\text { Spike } \\
\text { length } \mathbf{( c m})\end{array}$ & $\begin{array}{l}\text { Number of spikes } \\
\text { per panicle }\end{array}$ & $\begin{array}{l}\text { Number of } \\
\text { tillers }\end{array}$ & $\begin{array}{l}\mathbf{1 0 0 0} \text { whole grain } \\
\text { weight } \mathbf{( g )}\end{array}$ & $\begin{array}{l}\text { Grain yield } \\
\left(\mathbf{t} \cdot \mathbf{h a} \mathbf{a}^{-\mathbf{1}}\right)\end{array}$ \\
\hline FL06747 & $88.75 \mathrm{a}$ & $30.00 \mathrm{a}$ & $21.60 \mathrm{a}$ & $13.40 \mathrm{a}$ & $32.1 \mathrm{a}$ & $11.575 \mathrm{a}$ \\
FL08224 & $83.95 \mathrm{a}$ & $28.50 \mathrm{ab}$ & $19.80 \mathrm{ab}$ & $11.00 \mathrm{ab}$ & $30.2 \mathrm{ab}$ & $9.850 \mathrm{ab}$ \\
INIFLAR R & $72.85 \mathrm{~b}$ & $27.20 \mathrm{bc}$ & $15.20 \mathrm{c}$ & $9.20 \mathrm{~b}$ & $25.0 \mathrm{bc}$ & $11.512 \mathrm{a}$ \\
INIFLAR RT & $69.85 \mathrm{~b}$ & $24.90 \mathrm{~cd}$ & $17.40 \mathrm{bc}$ & $10.80 \mathrm{~b}$ & $23.7 \mathrm{c}$ & $9.050 \mathrm{~b}$ \\
Marfil & $71.70 \mathrm{~b}$ & $24.70 \mathrm{~cd}$ & $17.00 \mathrm{bc}$ & $9.20 \mathrm{~b}$ & $25.0 \mathrm{bc}$ & $9.737 \mathrm{ab}$ \\
Lombardia & $71.80 \mathrm{~b}$ & $25.00 \mathrm{~cd}$ & $18.80 \mathrm{ab}$ & $10.60 \mathrm{~b}$ & $24.5 \mathrm{bc}$ & $10.200 \mathrm{ab}$ \\
Milagro Filipino & $67.95 \mathrm{~b}$ & $23.00 \mathrm{~d}$ & $19.40 \mathrm{ab}$ & $11.60 \mathrm{ab}$ & $28.5 \mathrm{abc}$ & $8.200 \mathrm{~b}$ \\
\hline
\end{tabular}

Table 8. Results of validation trial 2 of seven rice genotypes in the municipality of Paracuaro Michoacán, Mexico, in spring-summer cycle 2015 [20]. 


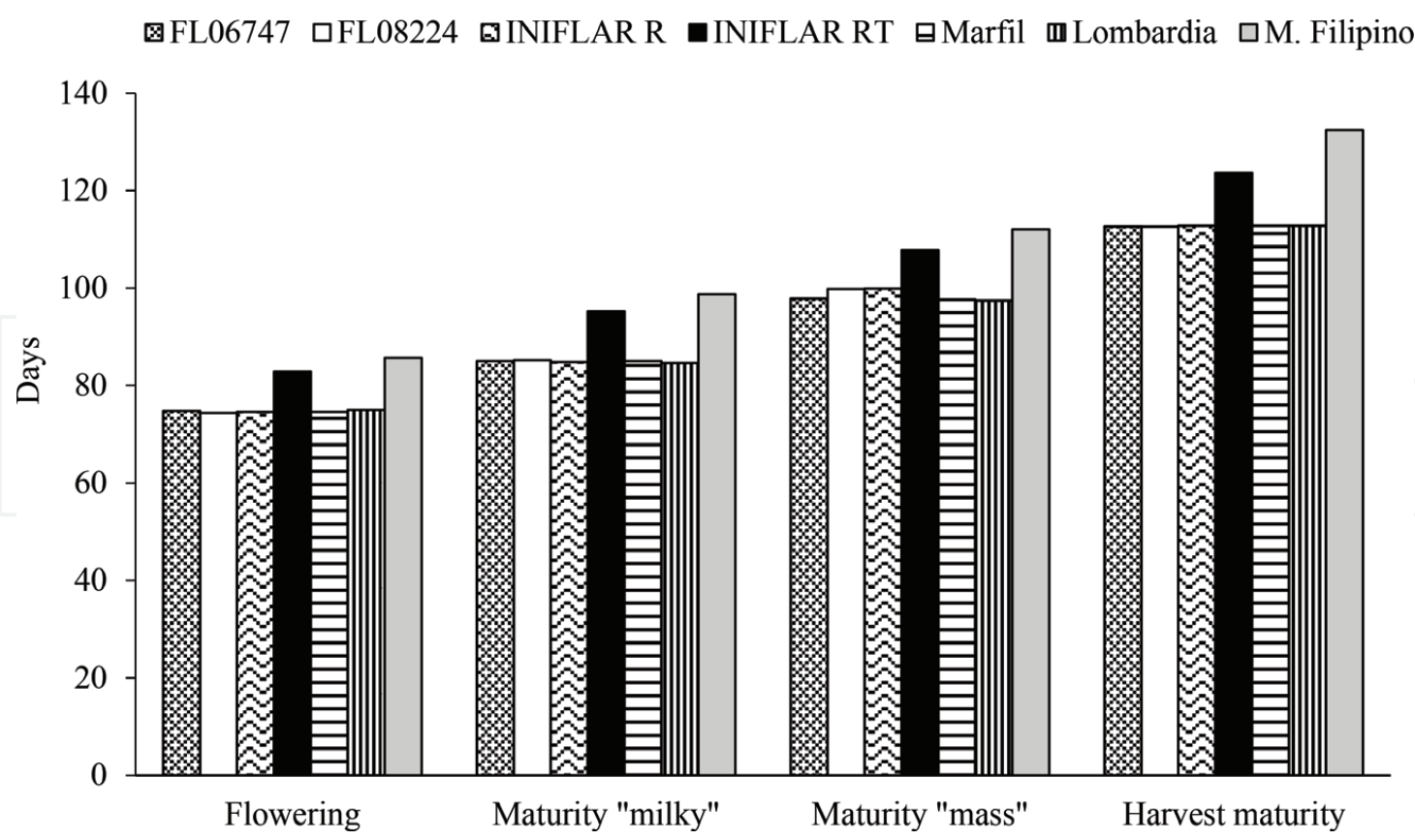

Figure 1. The time of flowering and maturity of seven rice genotypes in validation trial 2 in Paracuaro Michoacán, Mexico, during spring-summer cycle 2015 [21].

observed, the different stages of the maturity of the grain appeared more quickly in the materials of long and thin grain (Figure 1), a situation clearly observed in the Milagro Filipino variety. It is also important to point out that in addition to this property, aspects such as tolerance to abiotic stresses need to be explored [29] in order to identify candidate lines with enhanced performance under conditions of low water supply [30] and biotic stresses [26].

On the other hand, Table 9 shows the results of validation trial 3 experiment where plant height and grain yield were evaluated although significant difference was obtained only for grain yield. It is important to note that this validation trial was developed in the municipality of Nuevo Urecho Michoacán, Mexico, and although the edapho-climatic characteristics suggested in the corresponding section are similar, the grain yield of the FL08224 treatment was inferior to the grain yield presented in the validation plot. With this same material, the interpretation for this purpose may be due to the productive systems from the point of seed quality and adaptability. This situation may occur, since it should be noted that yield is a complex quantitative character that is largely influenced by environmental fluctuations [31].

\begin{tabular}{lll}
\hline Genotypes & Plant height $(\mathbf{c m})$ & Grain yield $\left(\mathbf{t} \cdot \mathbf{h a}^{-\mathbf{1}}\right)$ \\
\hline Lombardia & 71.08 & $12.003 \mathrm{a}$ \\
FL08224 & 67.87 & $7.730 \mathrm{~b}$ \\
Milagro Filipino & 68.91 & $8.255 \mathrm{~b}$ \\
\hline
\end{tabular}

Table 9. Effects of genotypes on plant height and grain yield for validation trial 3 study in rice in the municipality of Nuevo Urecho, Michoacán, Mexico, during spring-summer cycle 2016 [19]. 


\section{Rice production technologies in Michoacán, Mexico}

In Mexico, from 1993 to date, the introduction and exchange of rice germplasm is only carried out by INIFAP through the National Bank of Rice Germplasm with headquarters in "Zacatepec" Experimental Field, whose flow comes from international organizations and producer states in the country [32].

On the other hand, the production technology of rice cultivation in the "Valley of Apatzingan", Michoacán, Mexico, represented mainly by the introduction of seed treatment with insecticide and fungicide, the reduction of seed rate per hectare, direct sowing in furrows and irrigation, the use of new-generation herbicides, the optimal application of irrigation quantity, and the use of new varieties, is widely adopted by producers and was obtained through research work carried out by INIFAP [33].

\subsection{Direct sowing of seed in furrows}

Direct sowing in furrows is considered as an alternative to reduce production costs, make water use and management more efficient since it does not require permanent flooding of the crop; the employed labor also decreases, and it does not require the construction of seedbeds, as well as of rice boards, all without affecting grain yield; this method can be implemented in most land of the region independently of whether you have irrigation or a temporary land with the possibility of irrigation supply [34].

The selection of the best sowing date is a very important decision, but it is not always possible to establish the most suitable date, even under irrigation conditions, sometimes it is not possible to establish the best dates due to the shortage of water or to the priority that the irrigation districts consider the different crops in the region [35]. In general, the sowing dates for the municipalities of the "Valle of Apatzingan" range from January 1 to February 15 (autumn-winter cycle) and from June 1 to July 15 (spring-summer cycle).

As indicated above, direct seeding in furrows has been optimized based on the following settings:

1. A fallow is previously made

2. Cross harrow passage

3. Marking of the furrows with a distance of $20-30 \mathrm{~cm}$ between one and the other

4. Sowing the seed manually or with a planter precision

5. First establishment irrigation

6. Weed control with herbicides pre-emergent and in its case post-emergent.

In previous evaluations developed by INIFAP, it has been found that with the furrow seeding system, $80-100 \mathrm{~kg}$ of seed per hectare can be used. Higher densities may aggravate problems of lodging during crop maturity due to the weakening of the stems and to the development of a greater height of the plants by an excessive competition [35]. 


\subsection{Seed treatment}

Currently, seed treatment is a very important option to reduce the damage caused by fungal diseases and to prevent the attack of soil pests on germination, which is when the rice cultivation is more susceptible. One of the advantages of seed treatment is that it is economical and easy to perform, also to provide the plant with protection that goes from 30 to 40 days after emergence. There are different methods of seed treatment. In rice, the simplest and most used in the region is to start with a previous cleaning in order to eliminate damaged seeds, crop straw, and lumps and stones. Next, the amount of seed to be used for the sowing is spread on a smooth plot of land in order to sprinkle the seed directly with a sprinkler backpack, attaining to moisten it with different existing products: Clotianidin $\left(3 \mathrm{ml} \cdot \mathrm{L}^{-1}\right.$ of water), Thiophanate methyl (2 g. $\mathrm{L}^{-1}$ of water), Benomilo (2 $\mathrm{g} \cdot \mathrm{L}^{-1}$ of water), Captan (2 $\mathrm{g} \cdot \mathrm{L}^{-1}$ water), and Imidacloprid ( $4 \mathrm{ml} \cdot \mathrm{L}^{-1}$ water). It is generally possible to sprinkle $100 \mathrm{~kg}$ of seed using $2-3 \mathrm{~L}$ of water plus the product to be used in dye to distinguish that this seed is treated and thus avoid accidents by ingestion [36].

\subsection{Efficiency in irrigation water management}

In the "Valley of Apatzingan," the most important factors limiting rice production are weeds, and the factors that limit the increase of the sown area are the production costs and the high irrigation volumes that are applied to the crop. A common practice is flood. Nonetheless, within basic crops, rice is the best option that guarantees economic benefits to the regional producer; however, the use of large volumes of irrigation promotes low levels of efficiency of this resource, which limits the planting of a larger area. Therefore, the research work has focused on reducing the volume of irrigation to the crop without reducing yield, in addition to determining the volume of water needed and the frequency of irrigation to obtain a high grain yield. Five treatments were established in the municipality of Parácuaro, Michoacán, Mexico, during three cultivation cycles: (1) control, (2) irrigation every 2 days, (3) irrigation every 3 days, (4) 9 irrigation and 3 periods of flooding, and (5) 12 irrigation and 3 periods of flooding. It is verified that all the treatments significantly reduced the volume of water in comparison with the regional control without affecting the grain yield in a significant way (Table 10), which produces a greater efficiency in the use of water. The control produced the

\begin{tabular}{llllll}
\hline Treatments & $\begin{array}{l}\text { Yield } \\
\left(\mathbf{t} \cdot \mathbf{h a}^{-\mathbf{1}}\right)\end{array}$ & $\begin{array}{l}\text { Water amount } \\
\left(\mathbf{m}^{\mathbf{3}} \cdot \mathbf{h} \mathbf{a}^{-\mathbf{1}}\right)\end{array}$ & $\begin{array}{l}\text { Quantity of } \\
\text { water }(\mathbf{m})\end{array}$ & $\begin{array}{l}\text { Efficiency of water } \\
\mathbf{u s e}\left(\mathbf{k g} \cdot \mathbf{m}^{\mathbf{3}}\right)\end{array}$ & $\begin{array}{l}\text { Flood time } \\
(\mathbf{d a y s})\end{array}$ \\
\hline 1 (Control) & 9.7 & 308,500 & 30.8 & 3.1 & 90 \\
2 (irrigation every 2 days) & 8.5 & 17,400 & 1.7 & 48.8 & 4 \\
3 (watering every 3 days) & 8.4 & 11,300 & 1.1 & 74.3 & 4 \\
$\begin{array}{l}\text { (nine supplemental irrigation and } \\
\text { three periods of flooding) }\end{array}$ & 9.2 & 79,300 & 7.9 & 11.6 & 20 \\
$\begin{array}{l}5 \text { (12 supplemental irrigation and three } \\
\text { periods of flooding) }\end{array}$ & 9.0 & 81,900 & 8.2 & 10.9 & 20 \\
\hline
\end{tabular}

Table 10. Grain yield and irrigation parameters in rice, in the municipality of Paracuaro Michoacán, Mexico [34, 37]. 
largest amount of rice $\left(9.8 \mathrm{t} \cdot \mathrm{ha}^{-1}\right)$, although it was not significantly different from the lowest yield reported earlier [34, 37].

However, the differences in the application of water are highly contrasting (Table 10), since the control, due to most of the flooded cycle, required a large amount of water. It is assumed that a large part of the water is lost by draining and it is not possible for the crop to take advantage of all the water supplied. Even when treatments 2 and 3 presented high-yield and low-water volumes applied, they have the limitation of their practical acceptance by the producer because they would raise production costs, for the payment of wages to effect irrigation according to the treatment.

Based on the above, without affecting yield, the time that rice cultivation remains flooded can be reduced by more than $75 \%$, which allows a considerable saving of water. Grain yield is not affected by reducing the volume of water by 20 times, compared to the flooded control. In a practical way, irrigation can be done every 10 days from sowing, with three periods of flooding at 25,80 , and 95 days, of 4,8 , and 8 days, respectively [34].

\subsection{Management of nutrition in rice}

Rice can be grown in any type of soil, when the humidity conditions are between saturation and field capacity depending on the phenological stage of the crop. The most important characteristics that a rice soil must meet are its ability to absorb and retain moisture; besides their physical and chemical characteristics, hard ground, soil depth, and topography must be taken into account; however, soils with a high clay content are the most appropriate for cultivation, due to their moisture retention capacity. Commonly, agricultural soils contain insufficient amounts of one or more elements essential for nutrition, so it is necessary to add them directly in the form of organic fertilizers or chemical fertilizers; however, a fertile soil contributes nitrogen to the crop, and although it is necessary to make applications of this nutrient, it is not recommended that it be done excessively because it can result in nutritional imbalances, succulence of the plant that favors the attack of pests and diseases and increases the contamination of the aquifers.

The amount of chemical fertilizer that is required to obtain high yields in rice cultivation is variable and is a function of the climate, the soil, and the type of crop that has been established in the previous cycle [38]. Other aspects that influence the efficiency of the fertilizer are the rice genotype and the production system. In addition, the efficient management of fertilization during the first stages of cultivation is influenced by adequate weed control, especially during the first 40 days after sowing, due to the competition effect. Other determining factors are seed quality, plant density, and solar radiation [39].

The effect of fertilizer application on rice in the "Valley of Apatzingan", Michoacán, Mexico, is very clear and perfectly distinguishable between fertilized rice and an unfertilized rice. Rice soils, although fertile, however, are mostly deficient in nitrogen and organic matter, because they have been cultivated for many years through intensive agriculture. However, by applying 
fertilizers even at low doses (80 units of nitrogen), they can double or triple the grain yield, increasing from 3.0 to more than $7.0 \mathrm{t} \cdot \mathrm{ha}^{-1}$.

Yields vary depending on the variety and type of soil. Through different evaluations of fertilizers developed by INIFAP, doses and recommended methods of fertilization in rice cultivation have been determined. A study developed [36] recommends fertilizing with the dose $180-80$ of N-P, applying all the phosphorus (100\%) and 50\% of the nitrogen, 25 days after sowing and the rest of the nitrogen at flowering. Also, for long and thin grain materials, they respond positively to the dose $240-80$ of N-P, respectively. All fertilizer application must be fractioned. During sowing, it is not advisable to supply the nitrogen, while the applications of phosphorus should be $100 \%$ of the fertilizer in the sowing. Applications of nitrogen should begin 15 days after seedling emergence with one-third of the total recommended fertilizer dose equal to $80 \mathrm{~kg}$ of nitrogen; at the beginning of the "tillering," the other $33 \%$ of the dose should be applied, and in the stage of appearance of the floral primordium the rest of the nitrogen. If for practical purposes, it is decided to make two applications of fertilizer, apply $50 \%$ of the recommended dose 1 or 2 weeks after the emergency and the rest in the "tillering" stage.

Based on studies on nutrition in irrigated rice in the "Valley of Apatzingan", Michoacán, Mexico, it is reported that after laboratory and statistical analyses, it was determined that in rice for high grain yields, for the "FLAR 13" lines (lines Lombardia and Marfil), the following reference indices are suggested (Table 11) [40].

With the previous reference levels, the following determinations were made for the results obtained in the Marfil and Lombardia rice lines, whose analysis results are presented in Table 12.

Once the nutritional levels of the outstanding materials of rice are determined, the Kenworthy methodology was applied [41], to evaluate the nutritional condition of the rice, that is to say, its nutritional diagnosis. Figure 2 shows the nutritional diagnosis obtained in

\begin{tabular}{lll}
\hline Chemical element & Nitrogen (\%) & Coefficient of variation (\%) \\
\hline Nitrogen & 2.90 & 12.3 \\
Phosphorus & 0.15 & 14.1 \\
Potassium & 1.35 & 13.7 \\
\hline
\end{tabular}

Table 11. Foliar nutritional reference values (\%) of the three most important chemical elements for the long and thin grain rice "FLAR-13" in the "Valley of Apatzingan", Michoacán, Mexico [40].

\begin{tabular}{llll}
\hline Rice lines & Nitrogen $(\%)$ & Phosphorus $\mathbf{( \% )}$ & Potassium $(\%)$ \\
\hline Marfil & 2.2 & 0.18 & 1.76 \\
Lombardia & 2.4 & 0.21 & 1.85 \\
\hline
\end{tabular}

Table 12. Foliar analysis of outstanding rice lines in the "Valley of Apatzingan", Michoacán, Mexico [40]. 


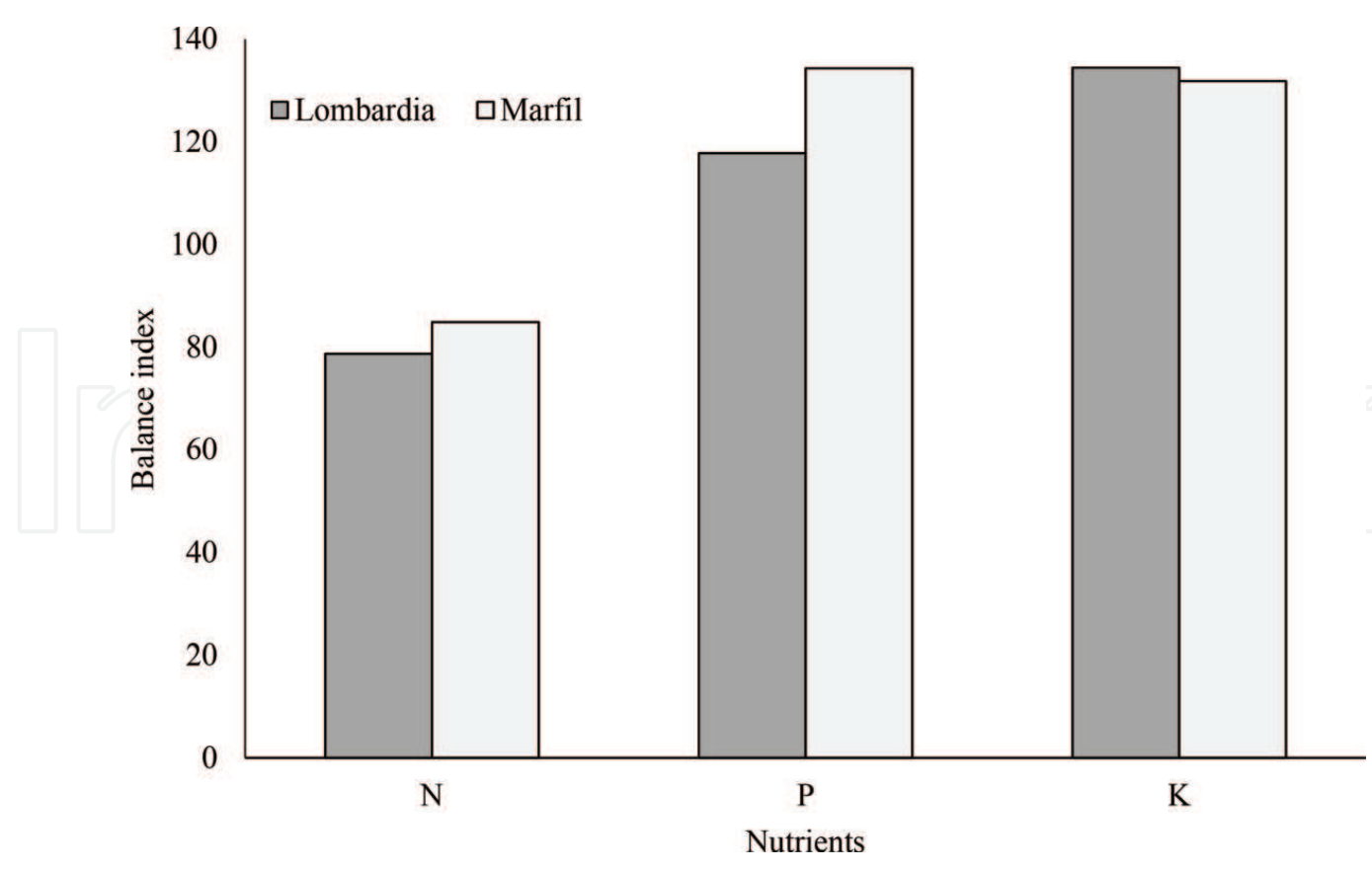

Figure 2. Nutritional diagnosis of two rice lines (Lombardia and Mafil) in the "Valley of Apatzingan", Michoacán, Mexico [40].

two rice materials for the "Valley of Apatzingan", Michoacán, Mexico. As can be seen, there was a higher nutritional imbalance in Marfil line than in Lombardia, while in both rice lines, potassium was the most unbalanced mineral; however, it was notable that the nitrogen was in an adequate balance which may indicate that this element was well supplied and in the proper doses.

Based on this investigation, to produce 1 ton of rice, the plant needs to absorb $20 \mathrm{~kg}$ of nitrogen, $4 \mathrm{~kg}$ of phosphorus, and $32 \mathrm{~kg}$ of potassium. Detailed amounts of nutrients required for rice in the "Valley of Apatzingan", Michoacán, Mexico, based on extraction levels of macronutrients are shown in Table 13, where both high and low extractions are observed for each ton of grain produced [40], which serve as reference for designing fertilization program. It should be noted that research has shown that in Michoacán, there is no response to potassium in cereals.

Rice cultivation, as indicated, has an excellent response to fertilization doses; in the Lombardia rice line, the response of the cereal was evaluated at increasing doses of nitrogen, generating the classic linear response, and if the doses continue to grow, then the yield is reduced as shown in Figure 3. The function allows the optimization of the amount of fertilizer to be applied as shown in the following sequence [40].

\begin{tabular}{llll}
\hline Extraction level & Total N & P & K \\
\hline High & 13.6 & 2.5 & 4.9 \\
Low & 8.96 & 2.6 & 3.6 \\
\hline
\end{tabular}

Table 13. Extraction of macronutrients $\mathrm{N}, \mathrm{P}, \mathrm{K}$ in the rice crop in $\mathrm{kg} \cdot \mathrm{t}^{-1}$ of whole rice [40]. 


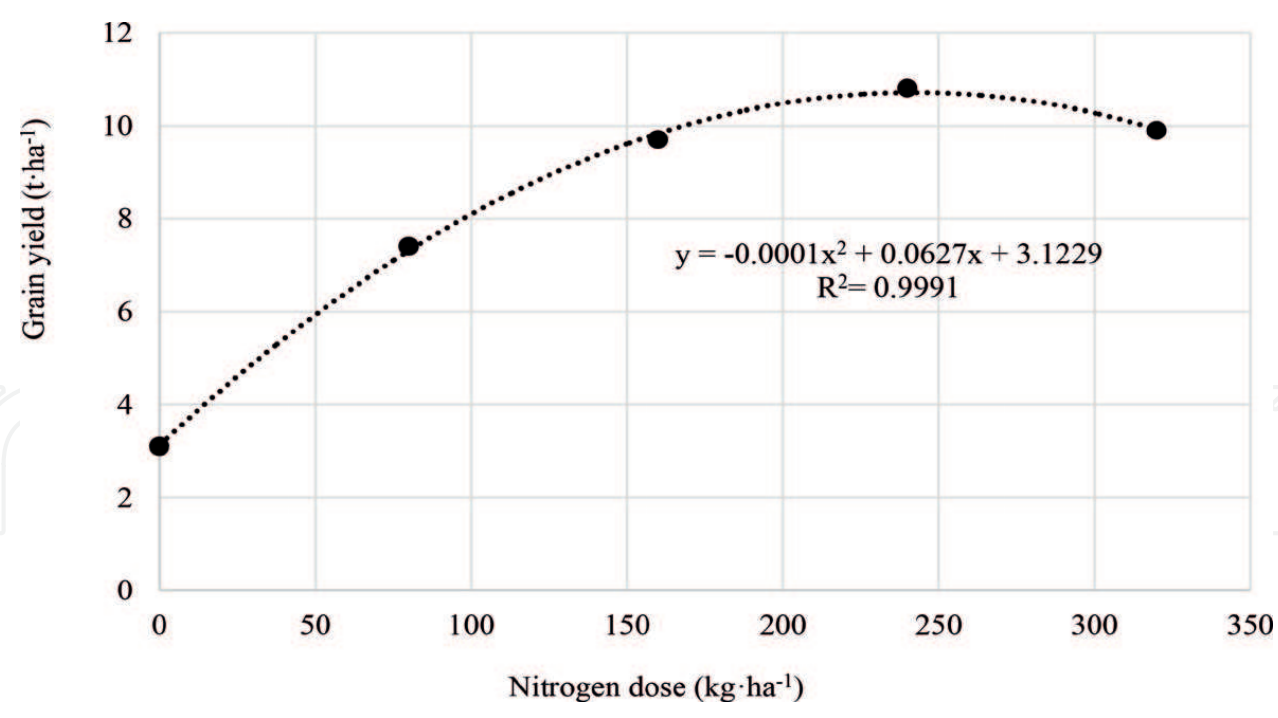

Figure 3. The response of Lombardia rice line to increasing doses of nitrogen [40].

\section{Conclusion}

Rice cultivation needs to remain under investigation in order to meet the demands of the producers and reduce the excess in imports of the long thin grain of rice, the release materials of long grain and thin rice, for the "Valley of Apatzingan" region is extremely important, thus achieving a variety with high yields under the conditions of irrigation, taking into account that the shortage of water is the main problem, that is why evaluation must be made in the application of the amount of irrigation required without reducing the potential yields; the technology released by INIFAP of direct sowing and irrigation in furrows has proven its effectiveness, and its level of adoption is higher than $90 \%$ of rice farmers in the region.

The soils of the region have very good aggregation and moisture consistency but low in organic matter and nitrogen. Hence, fertilizers are essential for achieving high grain yields, and the inclusion of organic fertilizers is an option to improve the physical and chemical properties of rice soils. Weeds are major constraints to rice cultivation. The best time to control weeds using herbicides is at 2-3 leaf stage of rice plant. The control of pests and diseases is necessary to take into account the economic damages they cause.

\section{Acknowledgements}

The authors wish to express their gratitude to the National Council of Science and Technology (CONACYT, by its acronyms in Spanish) and the Ministry of Agriculture, Livestock, Rural Development, Fisheries and Food (SAGARPA, by its acronyms in Spanish) for financing most of the researches developed, sectoral fund project SAGARPA-CONACYT (No. 148859). The authors also thank the team of researchers in Mexico under the direction of Dr. Leonardo 
Hernandez Aragon, everybody assigned to the National Institute of Forestry, Agriculture and Livestock Research (INIFAP, by its acronyms in Spanish), and the organized groups of rice farmers from Mexico.

\section{Author details}

Juan Carlos Álvarez-Hernández ${ }^{1 *}$, Luis Mario Tapia-Vargas ${ }^{2}$ and Anselmo Hernández-Perez ${ }^{1}$ *Address all correspondence to: alvarez.juan@inifap.gob.mx

1 "Valley of Apatzingan" Experimental Field-“Pacific Center" Regional Research Center, National Institute of Forestry, Agriculture and Livestock Research, Antunez, Michoacan, Mexico

2 Uruapan Experimental Field-“Pacific Center” Regional Research Center, National Institute of Forestry, Agriculture and Livestock Research, Uruapan, Michoacan, Mexico

\section{References}

[1] Ireta PAR, Garza LEB, Mora JSF, Peña BVO. Analysis of competitiveness of the rice (Oriza sativa) chain in southern Morelos, Mexico, with the CADIAC approach. Agrociencia. 2011; 45(2):259-265

[2] Arriaga JJ. Validation of two outstanding genotypes of rice cycle autumn-winter in Parácuaro, Mich [thesis]. Uruapan Michoacan, Mexico: Michoacana University of Saint Nicolas of Hidalgo; 2015

[3] Pimentel CN. Evaluation of long grain rice experimental lines in the autumn-winter cycle in Lombardia, municipality by Gabriel Zamora, Mich [thesis]. Uruapan Michoacan, Mexico: Michoacana University of Saint Nicolas of Hidalgo; 2012

[4] Plancarte ZG. Evaluation and selection of 14 experimental long grain rice lines in Lombardia, Mich [thesis]. Uruapan Michoacen, Mexico: Michoacana University of Saint Nicolas of Hidalgo; 2012

[5] Barrios GEJ, Rodríguez MVH, Hernández AL, Tavitas FL, Hernández PA, Tapia VLM, Pinzón GJM. Evaluation of lines of thin grain rice for irrigation in Mexico. Interciencia. 2016;41(7):476-481

[6] Álvarez HJC, Tapia VLM, Tavitas FL. Iniflar R, new variety of long grain rice thin for irrigation producing regions Mexico. Mexican Journal of Agricultural Sciences. 2016;17: 3649-3654. ISSN 2007-9230

[7] Barrios GEJ, Hernández AL, Tavitas FL, Ortega AR, Jiménez CJA, Tapia LM, Morelos VH, Hernández PA, Esqueda EAV, Uresti DD. INIFLAR RT, variety of rice grain thin for Mexico. Mexican Journal of Agricultural Sciences. 2016;7(4):969-976. ISSN 2007-9230 
[8] García AJL, Hernández AL, Tavitas FL. El Silverio: A new rice cultivar for the tropical areas of Mexico. Mexican Journal of Agricultural Sciences. 2011;2(4):607-612. ISSN 2007-9230

[9] SIAP-SAGARPA. Statistics of national rice production [Internet]. 2016. Available from: http://infosiap.siap.gob.mx:8080/agricola_siap_gobmx/AvanceNacionalCultivo.do [Accessed: 10-09-2017]

[10] Bajracharya J, Steele KA, Jarvis DI, Sthapit BR, Witcombe JR. Rice landrace diversity in Nepal: Variability of agro-morphological traits and SSR markers in landraces from a highaltitude site. Field Crops Research. 2006;95:327-335

[11] Hernández AL, Tavitas FL, Candido PA, Jiménez CJA, López LR. Tecnologías y sistemas de producción. In: Hernández-Aragón L, Tavitas-Fuentes L, editors. El arroz en México. 1ra. ed. Mexico: INIFAP; 2016. p. 182-245. ISBN: 978-607-37-0584-4

[12] García E. Modificaciones al sistema de clasificación climática de Köppen, para adaptarlo a las condiciones de la República Mexicana. 4ta. ed. Vol. 1988. Mexico: UNAM. p. 246

[13] INEGI. Carta Edafológica E. 13-3. Escala 1: 250,000. Colima, Mexico: Instituto Nacional de Geografía Estadística e Informática; 1983

[14] INEGI. Anuario estadístico y geográfico de Michoacán de Ocampo 2016. Mexico: Instituto Nacional de Estadística y Geografía; 2016. p. 723. ISBN 978-607-739-858-5

[15] García RI, Linares LA. Árboles y arbustos de la cuenca del rio Tepalcatepec (Michoacán y Jalisco, Mexico) para uso urbano. 1ra ed. El Colegio de Michoacán A. C. e Instituto Politécnico Nacional. Mexico; 2012. 304 p. ISBN: 978-607-8257-07-2

[16] Andrés AJ, Arteaga LG, Blancarte DM, Calderón AJH, López PV, Rivera MS, Romero PJ, Santos CC. La producción agropecuaria de la región Valle de Tepalcatepec Michoacán. 1ra. ed. Vol. 1994. Mexico: Universidad Autónoma de Chapingo. p. 652

[17] Pérez PF, Armas PR. Evaluation of genetic materials of thin long grain rice for the Apatzingan Valley region, Michoacan [thesis]. Uruapan Michoacan, Mexico: Michoacana University of Saint Nicolas of Hidalgo; 2015

[18] Reyes BA. Evaluation and selection of 14 experimental long grain rice lines for Lombardia, Municipality by Gabriel Zamora, Mich [thesis]. Uruapan Michoacan, Mexico: Michoacana University of Saint Nicolas of Hidalgo; 2011

[19] Álvarez HJC, Tapia VLM. Validación de materiales de arroz de grano largo y delgado en Michoacán. In: Memorias del $12^{\circ}$ Congreso Estatal de Ciencia Tecnología e Innovación; 5-6 Octubre 2017; Morelia Michoacan, Mexico. 2017. pp. 1-6

[20] Álvarez HJC, Tapia VLM. Introducción de materiales de arroz de grano largo y delgado para el Valle de Apatzingán. In: Memorias del $11^{\circ}$ Congreso Estatal de Ciencia Tecnología e Innovación; 13-14 Octubre 2016; Morelia Michoacan, Mexico. 2016. pp. 1-6. ISSN: 042016-082917280600-203

[21] Álvarez HJC, Tapia VLM. Comportamiento agronómico de líneas avanzadas de arroz de grano largo y delgado en Michoacán. In: Memorias del 3er. Congreso Nacional de Ciencia 
y Tecnología Agropecuaria; 14-16 Marzo 2016; Roque Celaya Guanajuato, Mexico. 2016. pp. 585-589. ISSN: $2448-6620$

[22] Esqueda EVA, Tosquy VOH. Validation of Cyhalofop-butyl + clomazone to control Echinochloa colona (L.) link in rainfed rice. Mexican Journal of Agricultural Sciences. 2014; 5(5):741-751

[23] SAS Institute Inc. The SAS System for Windows 9.0. Cary, N.C.; 2002

[24] Tapia VLM, Álvarez HJC, Larios GA, Hernández PA, Vidales FI. Evaluación de líneas avanzadas de arroz de grano largo delgado bajo riego en Parácuaro, Michoacán. In: Memorias del XVIII Congreso Internacional en Ciencias Agrícolas; 29-30 Octubre 2015; Mexicali Baja California, Mexico. 2015. pp. 960-965. ISBN: 978-0-9967556-0-3

[25] Díaz SSH, Pérez VF, Rosas CJ, Morejón RR. Response of different lines and cultivars of rice subjected to low temperatures under controlled conditions. Biotecnología Vegetal. 2017; 17(1):57-65

[26] Hernández-Arenas M, Barrios-Gómez EJ, Canul-Ku J, Berriozabal OA, RodríguezEspinoza JJ. Phytosanitary quality and chemical treatment to control pathogens in rice seeds Morelos type. Investigación Agropecuaria. 2012;9(2):103-111

[27] Lacerda MC, Nascente AS. Effects of row spacing and nitrogen topdressing fertilization on the yield of upland rice in a no-tillage system. Acta Scientiarum. 2016;38(4):493-502

[28] Fu J, Yang J. Research advances in high-yielding cultivation and physiology of super rice. Rice Science. 2012;19(3):177-184

[29] Díaz SH, Morejón R, Pérez NJ. Behavior and selection of rice advanced lines (Oryza sativa L.) obtained by breeding program in Los Palacios. Cultivos Tropicales. 2017;38(1):81-88

[30] González CMC, Martínez RA. Selección de mutantes de arroz de buen comportamiento agronómico en condiciones de bajo suministro de agua. Cultivos Tropicales. 2016;37(1): 102-109

[31] Orona CF, Medina MJ, Tucuch CFM, Soto RJM, Almeyda LIH. Stability parameters in yield and adaptability for rice 25 genotypes of Campeche, Mexico. International Journal of Experimental Botany. 2013;82:255-261

[32] Tavitas FL, Hernández AL. Los recursos genéticos de arroz y su utilización en México. Publicación Especial N. 40. SAGARPA-INIFAP-SINAREFI. C.E. Zacatepec, Morelos. 2004. p. 41

[33] Tapia VM, Muñoz VA. Effect of the water regime in the irrigated rice of the Apatzingán Valley. Agricultura Técnica en Mexico. 1996;22(2):157-174

[34] Tapia-Vargas L, Hernández-Pérez A, Larios-Guzmán A, Vidales-Fernández I. Producción de arroz Palay en la Región del Valle de Apatzingán. Folleto Técnico N. 1. Campo Experimental Valle de Apatzingan. Michoacan: Mexico. 2013. p. 64. ISBN: 978-607-0033-7 
[35] Osuna CFJ, Hernandez AL, Salcedo AJ, Tavitas FL, Gutiérrez DL. Manual para la producción de arroz en la región central de México. Libro Tecnico N. 1. INIFAP. Zacatepec: Morelos. 2000. p. 92. ISBN: 968-800-474-X

[36] Hernández PA, Tapia VLM, Larios GA, Vidales FI, Rico PHR. Tecnología para la producción de arroz en el trópico seco de Michoacan. Guía Técnica N. 1. INIFAPCIRPAC-Campo Experimental Valle de Apatzingan. 2013. p. 57. ISBN: 978-607-37-0071-9

[37] Ceja AE. Response to water stress in long-grain and thin-grain rice (Oryza sativa) in Lombardia Municipality of Gabriel Zamora, Michoacán, Mexico [thesis]. Uruapan Michoacan, Mexico: Michoacana University of Saint Nicolas of Hidalgo; 2014

[38] Pulver EL. Manejo estratégico y producción competitiva del arroz con riego en América Latina. In: Degiovanni VMB, Martínez CP, Motta FO, editors. Producción eco-eficiente del arroz en América Latina. Cali: Colombia: Centro Internacional de Agricultura Tropical (CIAT); 2010. pp. 350-362

[39] Hossain MF, Whitec SK, Elahid SF, Sultanad N, Choudhurye MHK, Alame QK, Rotherf JA, Gauntc JL. The efficiency of nitrogen fertilizer for rice in Bangladeshian farmers' fields. Field Crops Research. 2005;93(1):94-107

[40] Tapia VLM, Hernández PA, Álvarez HJC. Nutrición y manejo de fertilizantes. In: Hernández-Aragón L, Tavitas-Fuentes L, editors. El arroz en Mexico. 1ra. ed. Mexico: INIFAP; 2016. pp. 309-331. ISBN: 978-607-37-0584-4

[41] Kenworthy AL. Plant analysis and interpretation for horticulture crops. In: Hardy GW, editor. Plant Analysis. Special Publication 2. Madison,WI: Soil Science Society of America; 1967. pp. 59-75 

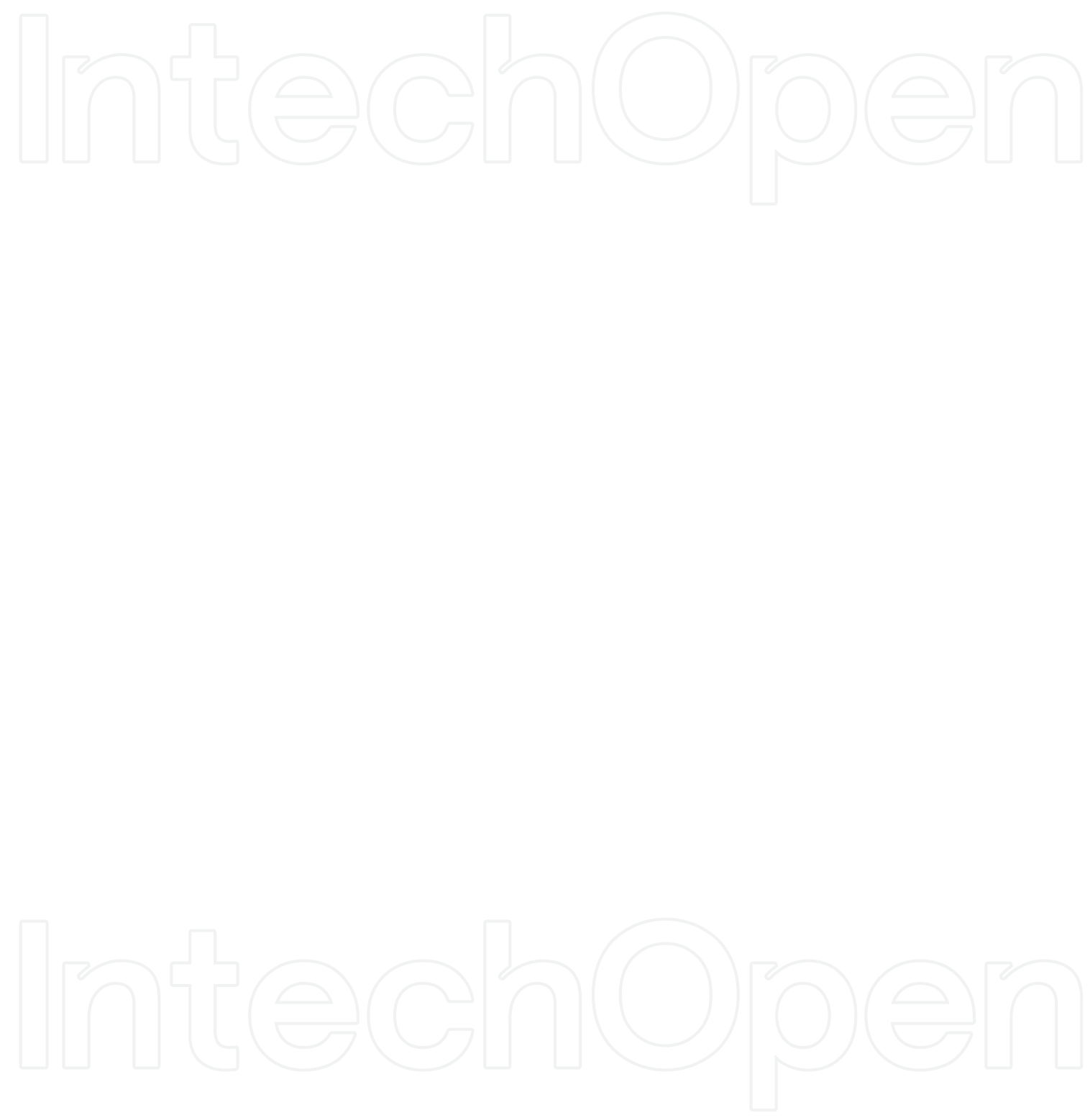


\title{
Economic Analysis of the Barley Market and Related Uses
}

\author{
Caterina Tricase, Vera Amicarelli, \\ Emilia Lamonaca and Roberto Leonardo Rana
}

Additional information is available at the end of the chapter

http://dx.doi.org/10.5772/intechopen.78967

\begin{abstract}
Barley is an important cereal worldwide cultivated since about 10,000 years. Barley crop is the fourth most important cereal in the world, after wheat, corn, and rice. It could be a food source for millions of people even though today it is mainly used as animal feed and brewing. So, recently, more than $70 \%$ of barley crop has been used for feed; about $21 \%$ has been intended to malting, brewing, and distilling industries; lesser than $6 \%$ has been consumed as human food. In addition, a growing interest in renewable energy has led to the modest use of barley grain for the production of fuel ethanol. The prominence of barley as food is mainly due to its potentialities in the production of healthy food, as an excellent source of dietary fiber, and a functional food ingredient such as $\beta$-glucan. The purpose of this chapter is to carry out an analysis of barley market and to present, in summary, its principal uses.
\end{abstract}

Keywords: barley, barley grain, barley market, barley feed, barley food

\section{Introduction}

Barley (Hordeum vulgare L.) is one of the ancient grain crops cultivated and used worldwide $[1,2]$. Its botanic origin is still well unknown although some studies affirm that the region were barley born could be identified in South-Eastern Asia, including China, Tibet, and Nepal [3,4]. Also, the pathways for its domestication have some points in doubt. However, the first examples of barley cultivation date back to about 10,000 years ago [5]. In fact, several archeological discoveries occur in South-Western Asia in the Fertile Crescent area (also known as the "cradle of civilization"), which indicate that the crop was domesticated about 
8000 BC. At later times, barley has been widely cultivated all over the world principally due to the commercial traffics. Thus, it grew in 5000 BC in Egypt, and successively, in 3500 BC, it diffused in Mesopotamia, then in 3000 BC in North-Western Europe, and 2000 BC in China. This plant was used to prepare the bread for the Hebrews, Greeks, and Romans and until the sixteenth century much throughout Europe. The introduction of other cereals in the human nutrition such as wheat, rice, and maize has led to a severe decrease of barley uses and cultivation [6].

Currently, barley is one of the fourth most important cereals in the world in terms of both quantity produced and cultivated areas. On average, the annual world harvest of barley is more that 140 million tons (Mt) obtained from nearly 50 million hectares (Mha) [7]. Moreover, barley is one of the most versatile cereals known to be well adapted to the different global climates through its genetic evolution [8, 9]. In fact, this plant grows outside the regions where the other cereals live (i.e., maize, wheat, and rice) such as arctic and subarctic zone to subtropical region. The barley's ability to adapt to the diverse conditions is supported by a rich genetic diversity being studied in order to identify new characters that can help improve the sustainability of the crop. This feature is mainly linked to the presence of genetic factors that allow synchronizing the vegetative cycle of the plant with the environment. This allowed to have early spring varieties suitable for environments with a prolonged cold weather and short spring-summer seasons and tardive winter varieties able to fully exploit all the productive potential of temperate climates. The good resistance to drought has also allowed the species to adapt to environments such as those of North Africa and the Middle East. In fact, the barley has a vast area of cultivation, from the humid regions of Europe to South America and the arid areas of Africa and Asia [10, 11]. Depending on climate conditions, soil characteristics, agricultural practices (i.e., irrigation), but also a variety of cultivated and technological innovations, barley's yield has changed during the time starting from 1.39 (in 1960) to $2.99 \mathrm{t} / \mathrm{ha}$ (in 2017). At present, the best yields are recorded in Zimbabwe, New Zealand, Chile, and Switzerland with about 7.5, 7.05, 6.50 and 6.17 t/ha, respectively [12].

Barley (Hordeum vulgare L.) is one of the most important cereals used, preceded only by wheat, rice, and maize. Barley is a versatile crop. Since ancient times, it has been used as food or for the production of beverages, and currently, it is mainly intended for the feeding of livestock [13]. Most probably, in the past, the first use was as food which then evolved into a feed, malting, and brewing, and its uses have changed throughout history and in different geographical area [14]. Currently, it is used in industrialized countries as a fodder and as a staple food in developing countries; however, the most significant use from an economic point of view is represented by malt and beer. It represents an important crop subsistence in the Andean and Himalayan regions and in Ethiopia. In Canada, instead, it is used for swine feed [10].

According to the FAO data, nowadays, about $70 \%$ of barley crop has been used for feed; $21 \%$ has been intended to malting, brewing, and distilling industries; $6 \%$ has been consumed as human food; in addition, a growing interest in renewable energy has led to the modest use of barley grain for the production of biofuels [15]. In 2017, the world production is around 141 Mt. Europe is the largest producer followed by Asia. 


\section{International barley market trend}

Barley is considered one of the most adaptable cereals; it is cultivated and used worldwide. It is used in different economic sectors such as animal feed, alcoholic beverage, food, and recently and particularly in Europe in biofuels production [16]. This ancient crop is the fourth most important cereal in the world; in 2017, its production was approximately equal to 141 Mt after corn (1060 Mt), wheat (749 Mt), and rice (741 Mt) (Figure 1) [1, 2, 7, 14]. During the last 50 years, although the harvesting area is decreased, the production was increased owing to the yields improving from about 1.4 in 1960 to $3 \mathrm{t} / \mathrm{ha}$ in 2017.

Moreover, European Union (EU) and Russia still represent the best world barley producers, reaching more than 58 and $20 \mathrm{Mt}$, respectively, in 2017. However, United States of America and Canada during the time have decreased their production probably due to the low income deriving from this culture with respect to others such as maize. On the contrary, Australia, Turkey, and Argentina have highly increased barley productions, reaching more than two to eight times than in 1960s. For instance, Australia showed one of the most significant increases in the total cropping area, from less than 1 in 1960s to 8 Mha in 2017 [12] (Figure 2).

In 2017, the total area harvested was around 50 Mha and ranked fourth after wheat $(\sim 220$ Mha), maize ( 183 Mha), and rice ( 162 Mha) [7, 12] (Figure 3).

From 1960 to the end of the 1970s, barley harvested area has shown a substantially increasing discontinuous trend. In the last 30 years, the harvesting area has been declining from almost 80 million ha to around 47 million ha. This trend is principally due to the significant decrease in barley cropping area of the major barley production countries such as Russia (including all the countries from former USSR), United States, India, and China (Figure 4).

In terms of annual yield, the period considered, from 1960 to 2017, is characterized by an increasing discontinuous trend, and it has increased in the last six decades from 1.3 in 1961

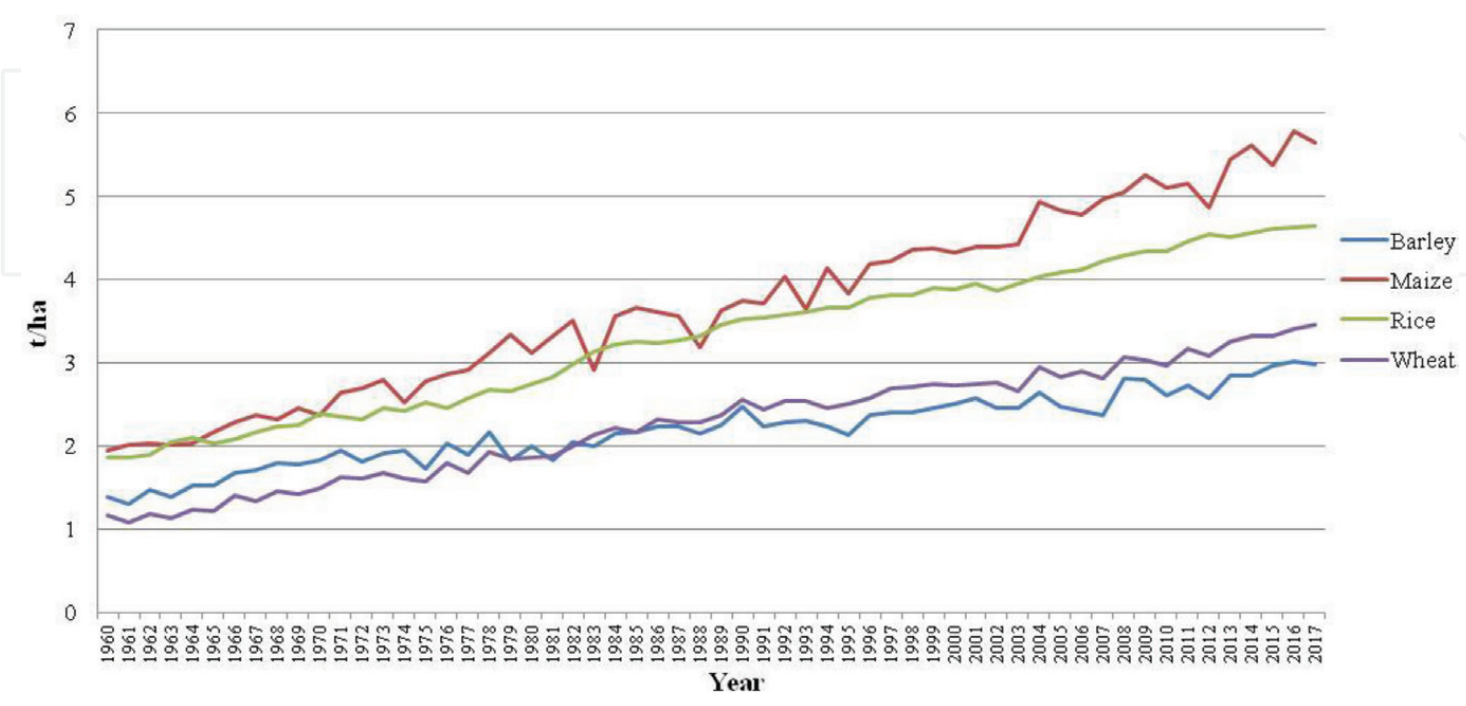

Figure 1. Trend of world production of barley, maize, rice, and wheat from 1960 to 2017 (source: elaborated from [7, 12]). 


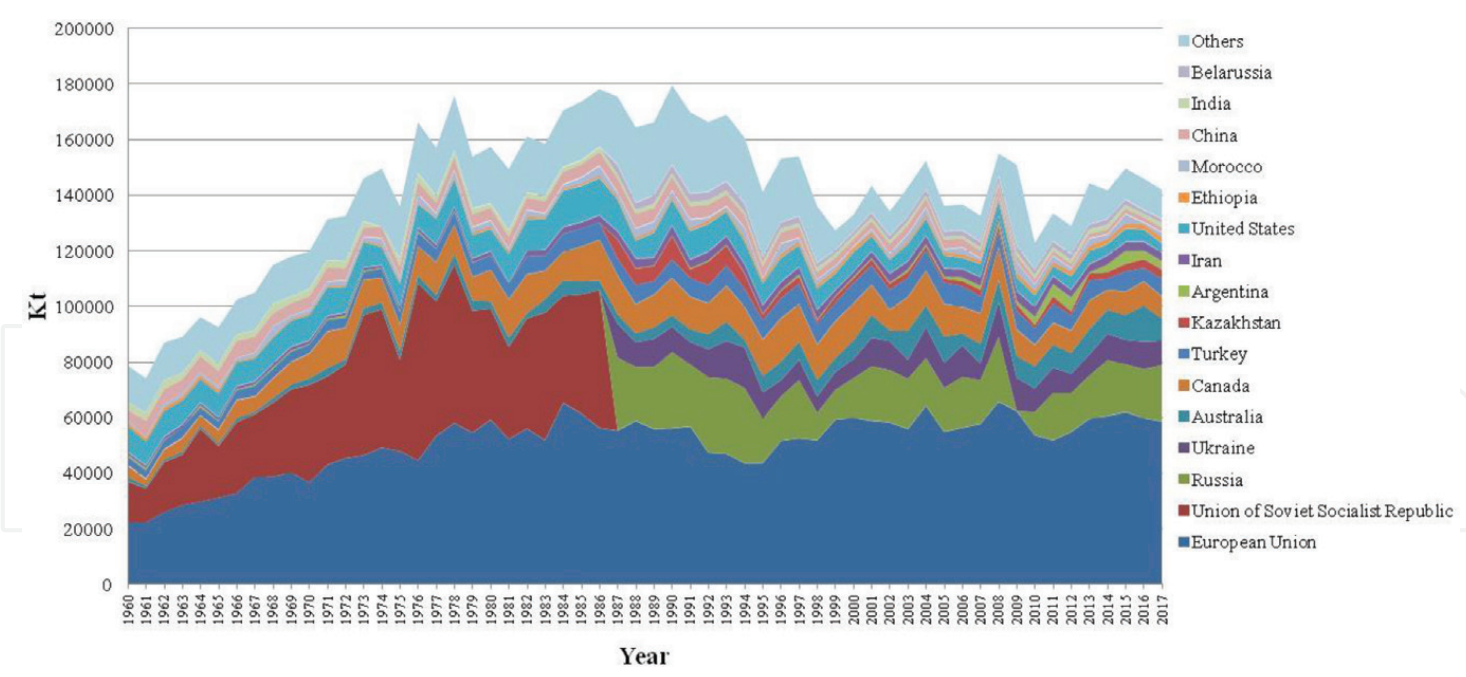

Figure 2. Trend of world barley production (including major barley production countries) (source: [12]).

to $3.01 \mathrm{t} /$ ha in 2017 [12]. As this discrepancy is underlined already between the increase in barley production and the reduction in harvested area, it is due to the improvement of yields. Furthermore, this trend is similar to the other cereals, since maize yield is raised, in the last six decades, from 1.9 (in 1961) to $5.65 \mathrm{t} / \mathrm{ha}$ (in 2017), rice from 1.9 to $4.6 \mathrm{t} / \mathrm{ha}$, and wheat from 1 to $3.46 \mathrm{t} / \mathrm{ha}$ [12]. This enhancement is mainly due to the introduction of technological innovations such as irrigation, no tillage soil management, or the introduction of new varieties much more productive than in the past.

In 2016, among the 106 barley country producers, only 10 contribute for the $65 \%$ (91.8 Mt) of the global production $(141 \mathrm{Mt})$ and the $60 \%$ (28.6 Mha) of the total barley harvested area (Table 1).

As shown in Table 1, the leader, in terms of production and area dedicated, is EU. In 2017, EU barley production was about equal to $59 \mathrm{Mt}$, which accounts for more than $40 \%$ of the global one, 25\% (11.5 Mha) of global barley harvested area (47 Mha) and with an average yield

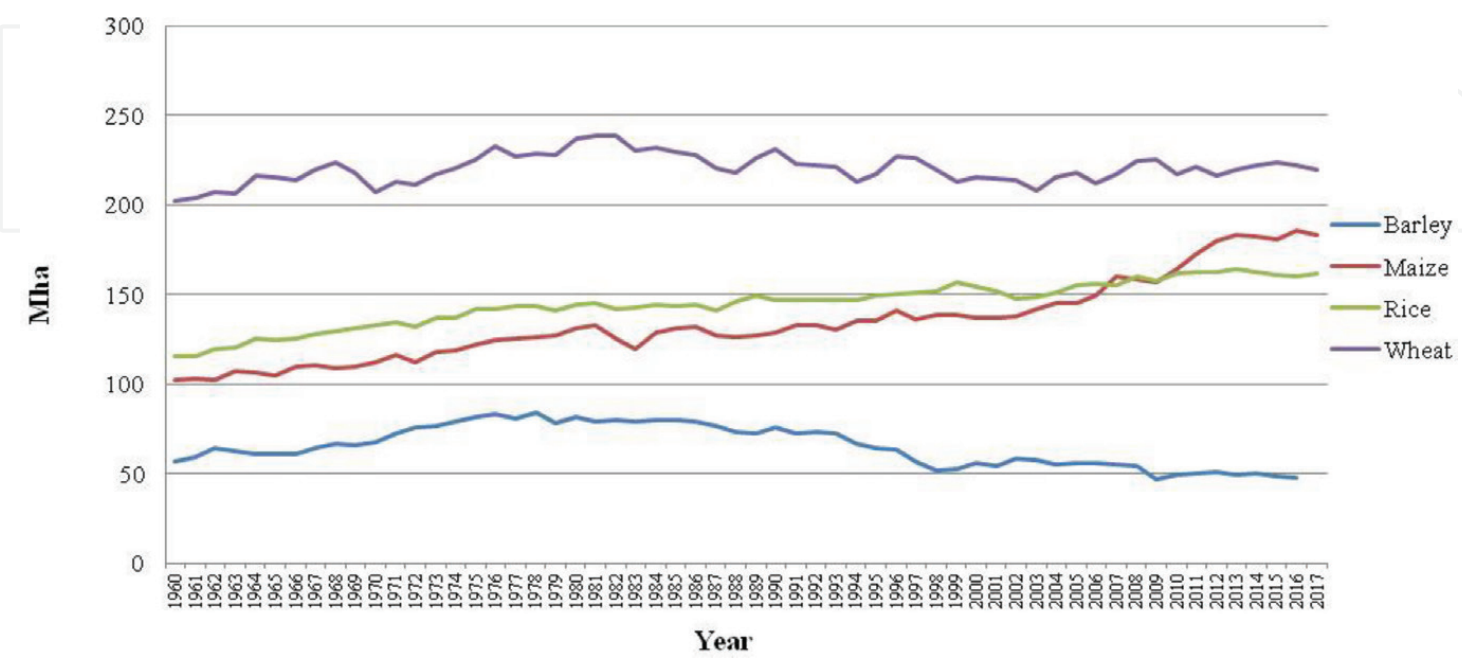

Figure 3. Trend of world harvested area of barley, maize, rice, and wheat from 1960 to 2017 (source: elaborated from $[7,12])$. 


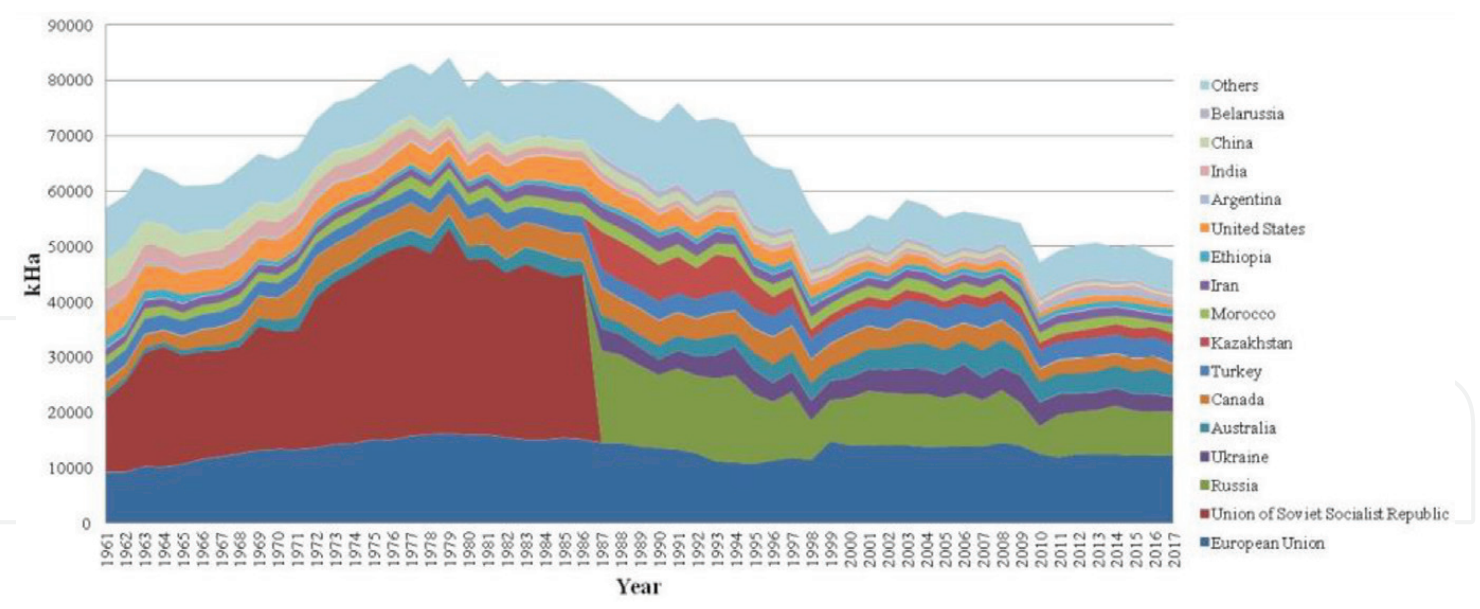

Figure 4. Trend of world barley harvested area (including major production countries) (source: elaborated from [7, 12]).

approximately equal to $4.5 \mathrm{t} / \mathrm{ha}$. In particular, Germany and France are the first and second European barley producers with 1.07 and $1.03 \mathrm{Mt}$, respectively, harvested approximately 1.6 and 1.8 Mha with an annual yield equal to 6.7 and $5.4 \mathrm{t} / \mathrm{ha}$. These countries are followed by other important producers such as Spain (7.9 Mt cultivated in 2.8 Mha) and United Kingdom (6.6 Mt cultivated in 1.1 Mha). These four European countries, together, contribute more than $35 \%$ of the total EU production, and each of them is included in the top 10 world barley producers $[7,14]$.

Russian Federation is the second world barley producer with $17 \mathrm{Mt}$ (12\% of global production) and 8 Mha (17\% of total harvested area) recorded a low average yield equal to $2.1 \mathrm{t} / \mathrm{ha}$. Following the main barley producers list are Ukraine and Australia with their barley production, respectively, equal to 9.4 and 8.9 Mt. Different are their annual yields (3.3 and 2.19 t/ha, respectively) and consequently the total dedicated area (2.8 and 4.1 Mha, respectively). As concerning the other producers, United State of America, Canada, Argentina, and China recorded

\begin{tabular}{|c|c|c|c|c|c|c|c|}
\hline Country & $\begin{array}{l}\text { Yield } \\
\text { (t/ha) }\end{array}$ & $\begin{array}{c}\text { Hervested } \\
\text { area (ha) }\end{array}$ & Production (t) & Country & $\begin{array}{l}\text { Yield } \\
\text { (t/ha) }\end{array}$ & $\begin{array}{c}\text { Hervested } \\
\text { area (ha) }\end{array}$ & Production (t) \\
\hline Europe an Union & 4.65 & 12507489 & 58233580 & Iran (Islamic Republic of) & 1.80 & 1611423 & 2907572 \\
\hline of which & & & & Ethiopia & 2.11 & 959273 & 2024922 \\
\hline Germany & 6.69 & 1605000 & 10730500 & China, mainland & 4.31 & 412781 & 1780355 \\
\hline France & 5.43 & 1899615 & 10306008 & India & 2.55 & 590000 & 1505000 \\
\hline Spain & 2.85 & 2800628 & 7979590 & Belarus & 2.78 & 450814 & 1252690 \\
\hline United Kingdom & 5.93 & 1122000 & 6655000 & Mexico & 2.97 & 329745 & 978349 \\
\hline Denmark & 5.59 & 706900 & 3949600 & Azerbaijan & 2.62 & 355129 & 928923 \\
\hline Russian Federation & 2.21 & 8133765 & 17992517 & Algeria & 1.30 & 706429 & 919907 \\
\hline Ukraine & 3.30 & 2859200 & 9435710 & Uruguay & 3.57 & 190000 & 678000 \\
\hline Australia & 2.19 & 4107648 & 8992274 & Norway & 4.57 & 137185 & 626900 \\
\hline Canada & 3.72 & 2336800 & 8704300 & Morocco & 0.51 & 1207615 & 619919 \\
\hline Turkey & 2.48 & 2700023 & 6700000 & Syrian Arab Republic & 0.57 & 879086 & 500001 \\
\hline United States of America & 4.19 & 1035200 & 4338850 & Cyprus & 2.00 & 14655 & 29300 \\
\hline Argentina & 3.80 & 870213 & 3308384 & Other Countries & & 5493877 & 15054283 \\
\hline Kazakhstan & 1.71 & 1894068 & 3231268 & Total & & 46923218 & 150743004 \\
\hline
\end{tabular}

Source: [7].

Table 1. World barley yield (t/ha) and production (t) in 2016. 
higher world average yields (4.19-3.72-3.80-4.31 t/ha, respectively); on the contrary, those in Kazakhstan, Iran, and Ethiopia are below the world average one (1.71-1.8-2.1 t/ha, respectively).

Regarding the import and export trade of the data available, more update is referred to 2016. So, the international barley trade accounts for less than $34 \%$ of global production, corresponding to a value of more than 9 million of US dollars (M US\$). The global barley trade has passed from $20 \mathrm{Mt}$ in 1990 to current $47 \mathrm{Mt}$. Leading barley exporters are EU (16 Mt), Australia (5.8 Mt), Argentina (3.2 Mt), and Russian Federation (2.8 Mt); together, they represent less than $92.5 \%$ $(28 \mathrm{Mt})$ of the total barley exported (Table 2).

EU exports approximately are equal to $9 \mathrm{Mt}$, representing $15 \%$ of its whole production (58 Mt) with a trade value of less than 1.7 M US\$. Among EU exporter countries, Netherlands, Belgium, and Germany are the principal ones totalizing the amount of $5 \mathrm{Mt}$ equal to the $56 \%$ of the global European exportation and approximately 1\% of world one. Germany, in 2016, was the second barley producer, the second importer and the third exporter (Table 3 ).

A long period trend of barley exports is shown in Figure 5. EU has modified its role in the international barley trade, since until 1975, it was one of the main importers, whereas after 1980, it became one of the principal exporters. Moreover, Ukraine, Russia, and Kazakhstan (former Union of Soviet Socialist Republic) and Australia have increased in the last two decades, their barley exportation becoming one of the largest world exporter countries after EU. Finally, Canada and USA have highly reduced their exportation activities starting from 2000s (Figure 5).

\begin{tabular}{|c|c|c|c|c|c|c|c|c|c|}
\hline Country & $\begin{array}{c}\text { Net } \\
\text { weight } \\
(t)\end{array}$ & $\begin{array}{c}\% \\
\text { on world } \\
\text { production }\end{array}$ & $\begin{array}{c}\text { Trade Value } \\
\text { (MUS\$) }\end{array}$ & $\begin{array}{c}\% \\
\text { on trade } \\
\text { value }\end{array}$ & Country & $\begin{array}{c}\text { Net } \\
\text { weight } \\
\text { (t) }\end{array}$ & $\begin{array}{c}\% \\
\text { on world } \\
\text { production }\end{array}$ & $\begin{array}{l}\text { Trade Value } \\
\text { (MUS\$) }\end{array}$ & $\begin{array}{c}\% \\
\text { on trade } \\
\text { value }\end{array}$ \\
\hline Australia & 5808572 & 4.111 & 1131059 & 26.25 & Belarus & 36130 & 0.026 & 4273 & 0.10 \\
\hline Argentina & 3227439 & 2.284 & 599701 & 13.92 & Croatia & 35850 & 0.025 & 6777 & 0.16 \\
\hline Russian Federation & 2862500 & 2.026 & 424390 & 9.85 & Latvia & 35463 & 0.025 & 5470 & 0.13 \\
\hline Netherlands & 2001543 & 1.416 & 361639 & 8.39 & Hungary & 34833 & 0.025 & 7397 & 0.17 \\
\hline Belgium & 1706453 & 1.208 & 324492 & 7.53 & United Arab Emirates & 31692 & 0.022 & 8701 & 0.20 \\
\hline Germany & 1272915 & 0.901 & 253227 & 5.88 & Bulgaria & 25068 & 0.018 & 4634 & 0.11 \\
\hline Canada & 1207325 & 0.854 & 293356 & 6.81 & Serbia & 23795 & 0.017 & 4944 & 0.11 \\
\hline Spain & 1102736 & 0.780 & 200324 & 4.65 & Slovenia & 22117 & 0.016 & 4128 & 0.10 \\
\hline Kazakhstan & 780557 & 0.552 & 109052 & 2.53 & Azerbaijan & 13854 & 0.010 & 2571 & 0.06 \\
\hline Italy & 731741 & 0.518 & 135382 & 3.14 & Malta & 12538 & 0.009 & 2282 & 0.05 \\
\hline Romania & 480421 & 0.340 & 78041 & 1.81 & Lithuania & 6150 & 0.004 & 1418 & 0.03 \\
\hline Portugal & 365521 & 0.259 & 67497 & 1.57 & Turkey & 5573 & 0.004 & 1399 & 0.03 \\
\hline Austria & 182467 & 0.129 & 33465 & 0.78 & Israel & 4841 & 0.003 & 1210 & 0.03 \\
\hline Greece & 179721 & 0.127 & 33253 & 0.77 & Estonia & 4504 & 0.003 & 989 & 0.02 \\
\hline Cyprus & 170991 & 0.121 & 31157 & 0.72 & USA & 2499 & 0.002 & 23942 & 0.56 \\
\hline Poland & 127977 & 0.091 & 21820 & 0.51 & Chile & 2275 & 0.002 & 739 & 0.02 \\
\hline United Kingdom & 125478 & 0.089 & 39448 & 0.92 & Lao People's Dem. Rep. & 1841 & 0.001 & 344 & 0.01 \\
\hline Rep. of Moldova & 114129 & 0.081 & 15554 & 0.36 & TFYR of Mace donia & 1765 & 0.001 & 296 & 0.01 \\
\hline Ireland & 90563 & 0.064 & 16442 & 0.38 & India & 1661 & 0.001 & 616 & 0.01 \\
\hline France & 60901 & 0.043 & 13785 & 0.32 & State of Palestine & 1635 & 0.001 & 303 & 0.01 \\
\hline Czechia & 45392 & 0.032 & 9325 & 0.22 & Finland & 1104 & 0.001 & 323 & 0.01 \\
\hline Slovakia & 44105 & 0.031 & 10180 & 0.24 & Luxembourg & 911 & 0.001 & 389 & 0.01 \\
\hline Uruguay & 41516 & 0.029 & 12583 & 0.29 & Other Countries & 2518 & 0.002 & 1573 & 0.04 \\
\hline Denmark & 36625 & 0.026 & 9064 & 0.21 & Total & 23076205 & 100 & 4308954 & 100 \\
\hline
\end{tabular}

Source: [7].

Table 2. Global barley trade: export in 2016. 


\begin{tabular}{|c|c|c|c|c|c|c|c|c|c|}
\hline Country & $\begin{array}{c}\text { Net } \\
\text { weight } \\
\text { (t) }\end{array}$ & $\begin{array}{c}\% \\
\text { on world } \\
\text { production }\end{array}$ & $\begin{array}{l}\text { Trade Value } \\
\text { (MUS\$) }\end{array}$ & $\begin{array}{c}\% \\
\text { on trade } \\
\text { value }\end{array}$ & Country & $\begin{array}{c}\text { Net } \\
\text { weight } \\
\text { (t) }\end{array}$ & $\begin{array}{c}\% \\
\text { on world } \\
\text { production }\end{array}$ & $\begin{array}{l}\text { Trade Value } \\
\text { (MUS\$) }\end{array}$ & $\begin{array}{c}\% \\
\text { on trade } \\
\text { value }\end{array}$ \\
\hline France & 5868270 & 17.40 & 1067796 & 16.17 & Finland & 184765 & 0.55 & 29399 & 0.45 \\
\hline China & 5004888 & 14.84 & 1141938 & 17.29 & Russian Federation & 158441 & 0.47 & 20343 & 0.31 \\
\hline Saudi Arabia & 3667337 & 10.88 & 713082 & 10.80 & Lebanon & 156997 & 0.47 & 27018 & 0.41 \\
\hline Germany & 2887398 & 8.56 & 499384 & 7.56 & Latvia & 148539 & 0.44 & 24104 & 0.37 \\
\hline United Kingdom & 1796240 & 5.33 & 313030 & 4.74 & India & 141757 & 0.42 & 29474 & 0.45 \\
\hline Romania & 1310986 & 3.89 & 214964 & 3.26 & Netherlands & 130298 & 0.39 & 28534 & 0.43 \\
\hline Japan & 1161549 & 3.44 & 261218 & 3.96 & Canada & 130087 & 0.39 & 28250 & 0.43 \\
\hline Morocco & 976845 & 2.90 & 179065 & 2.71 & Viet Nam & 115432 & 0.34 & 22297 & 0.34 \\
\hline Jordan & 956201 & 2.84 & 190100 & 2.88 & Oman & 109086 & 0.32 & 30462 & 0.46 \\
\hline Algeria & 879215 & 2.61 & 153413 & 2.32 & Austria & 108124 & 0.32 & 24749 & 0.37 \\
\hline Tunisia & 711213 & 2.11 & 121604 & 1.84 & Peru & 106535 & 0.32 & 33433 & 0.51 \\
\hline Denmark & 693665 & 2.06 & 142768 & 2.16 & Poland & 94377 & 0.28 & 15423 & 0.23 \\
\hline Brazil & 653779 & 1.94 & 169296 & 2.56 & Spain & 47890 & 0.14 & 14700 & 0.22 \\
\hline Hungary & 640382 & 1.90 & 100532 & 1.52 & Lithuania & 45390 & 0.13 & 7953 & 0.12 \\
\hline Czechia & 501108 & 1.49 & 86171 & 1.31 & Ireland & 29604 & 0.09 & 5810 & 0.09 \\
\hline Sweden & 479847 & 1.42 & 96871 & 1.47 & Portugal & 25768 & 0.08 & 5003 & 0.08 \\
\hline United Arab Emirates & 466826 & 1.38 & 103364 & 1.57 & Luxembourg & 18567 & 0.06 & 3341 & 0.05 \\
\hline Bulgaria & 412266 & 1.22 & 70023 & 1.06 & Croatia & 7030 & 0.02 & 1367 & 0.02 \\
\hline Kuwait & 384491 & 1.14 & 84033 & 1.27 & Slovenia & 5524 & 0.02 & 1065 & 0.02 \\
\hline USA & 347371 & 1.03 & 80261 & 1.22 & Italy & 3000 & 0.01 & 1215 & 0.02 \\
\hline Israel & 333438 & 0.99 & 63141 & 0.96 & Greece & 1368 & 0.00 & 481 & 0.01 \\
\hline Colombia & 297069 & 0.88 & 76707 & 1.16 & Cyprus & 0 & 0.00 & 2 & 0.00 \\
\hline Estonia & 274381 & 0.81 & 45961 & 0.70 & Malta & 0 & 0.00 & 0 & 0.00 \\
\hline Slovakia & 210888 & 0.63 & 35526 & 0.54 & Other Countries & 847725 & 2.51 & 202964 & 3.07 \\
\hline Belgium & 188171 & 0.56 & 35104 & 0.53 & Total & 2616303 & 7.76 & 557387 & 8.44 \\
\hline
\end{tabular}

Source: [7].

Table 3. Global barley trade: import in 2016.

On import side, in 2016, 17 Mt are traded, with a corresponding value equal to 3.7 M US\$. A long period trend of barley imports is recorded in Figure 6. China and Saudi Arabia are the main barley importer with $8.1 \mathrm{Mt}$ each, contributing to the total imported barley less than $50 \%$. The demand of Saudi Arabia barley is almost totally satisfied by import due to the country's scarce water reserves. This policy is supported by government subsidizing barley and

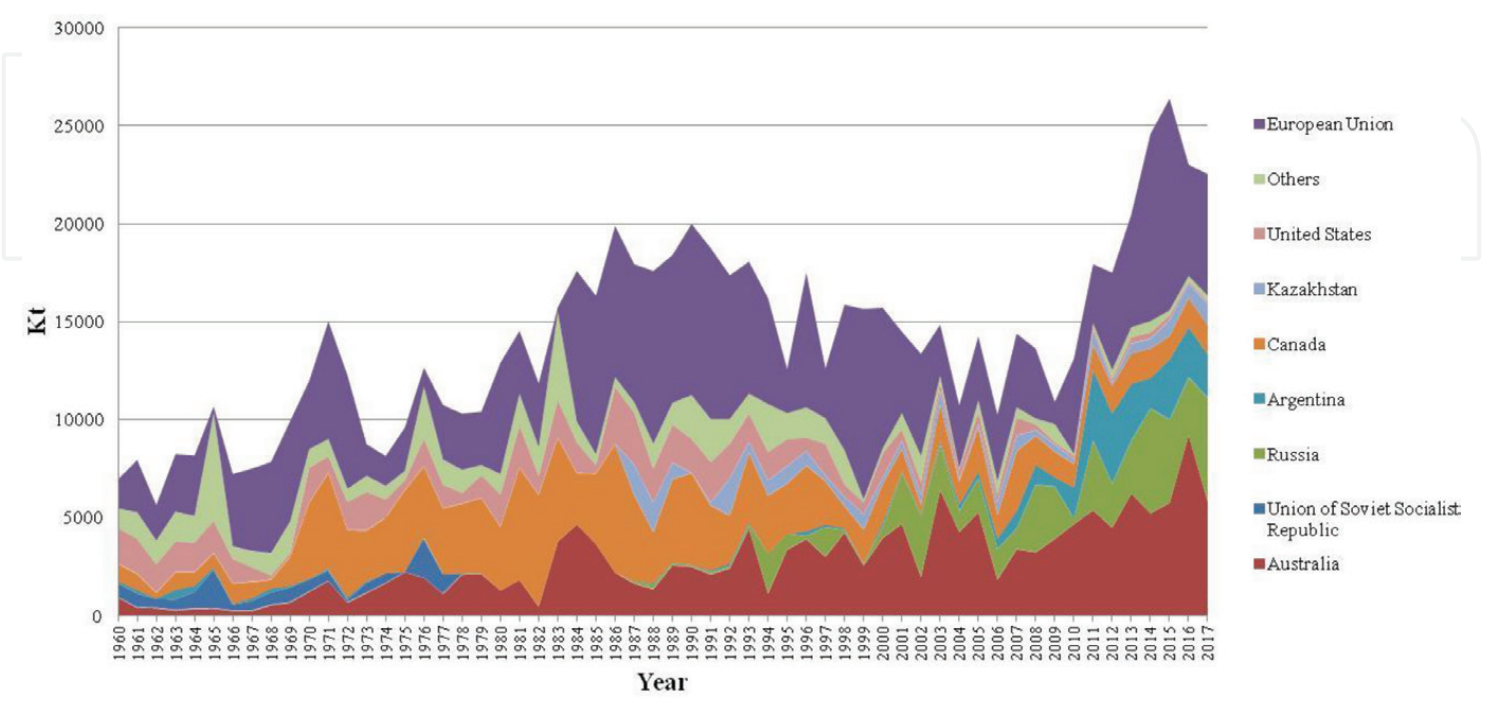

Figure 5. Trend of world barley exports (including the major country importer) (source: [12]). 


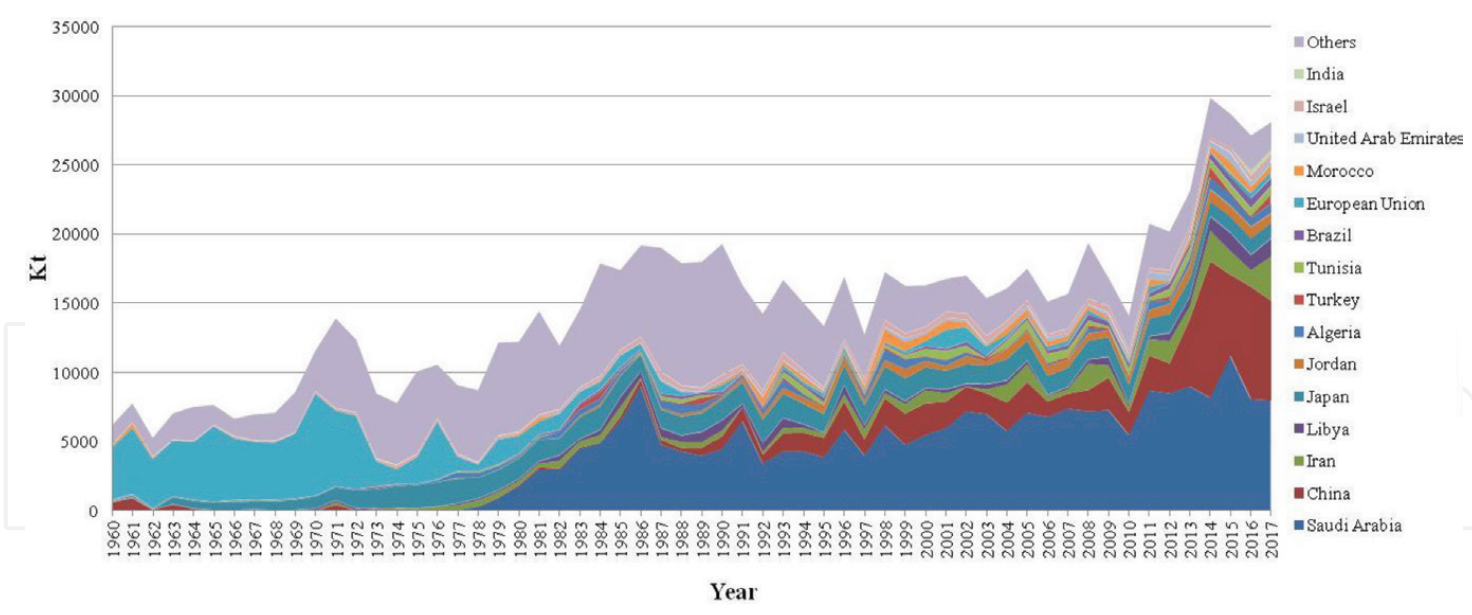

Figure 6. Trend of world barley imports (including the major country importer) (source: [12]).

based on the consideration that $100 \%$ of domestic barley (and wheat) cultivation is irrigated. The main quota of Saudi Arabia imported barley (more than $80 \%$ ) is principally utilized as feed for livestock, mostly sheep, camels, and goats. Its use in the place of forage depends on its price and competitiveness [17]. Moreover, barley is also used to prepare specialty and traditional Saudi dishes during Ramadan fasting time and as feed ingredients.

The price of barley has always been lower than the other grains (Figure 7). Starting from 1980 s to the middle of 1990 s, it has been under $100 \$ / t$, whereas later, it increased reaching a quotation more than $200 \$ / t$ in the year 2012. In the first 6 months of 2017, barley quotation was $146 \$ / t$, which started to increase again. This is due to different reasons such as (1) China's and Saudi Arabia's rise demand, (2) the reduction of global barley production, and (3) the projections of barley stock down in all major exporting countries [18].

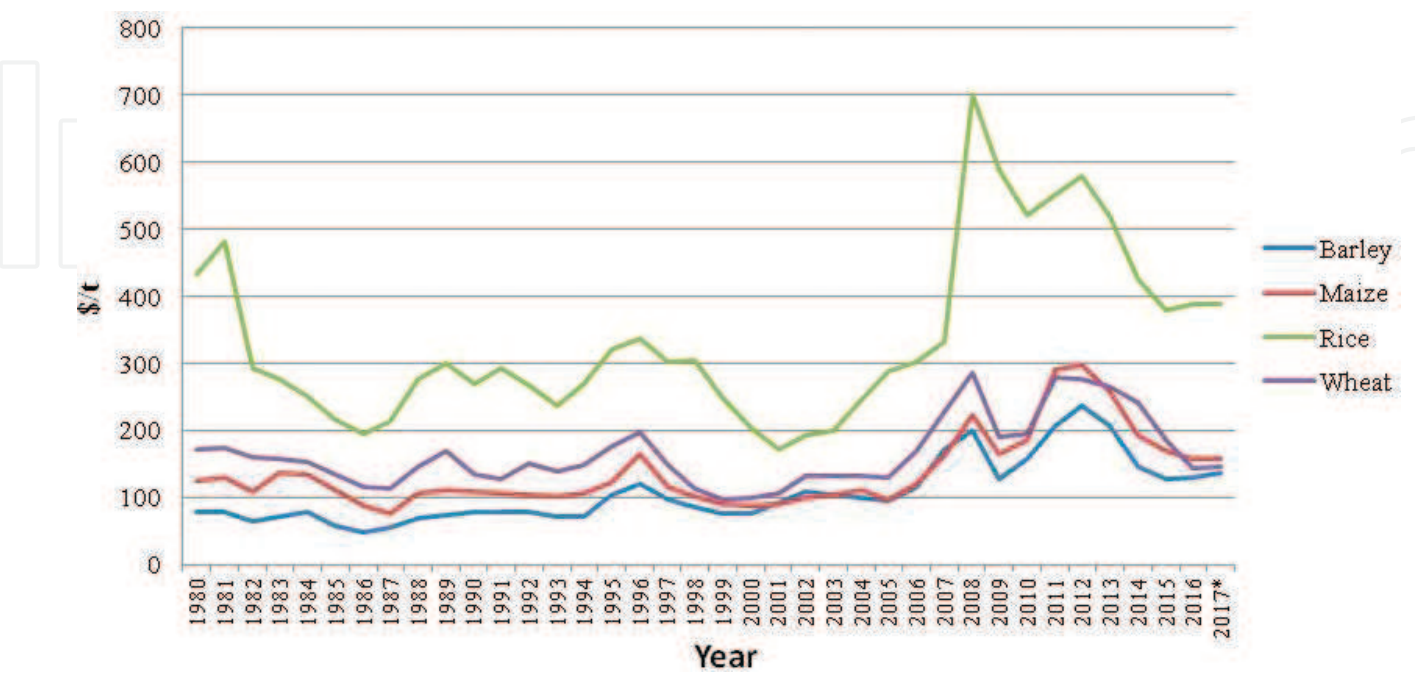

Figure 7. Trend of barley, maize, rice, and wheat price from 1980 to 2017 (source: [19]). ${ }^{*} 2017$ is considered the first 6 months from January to June. 


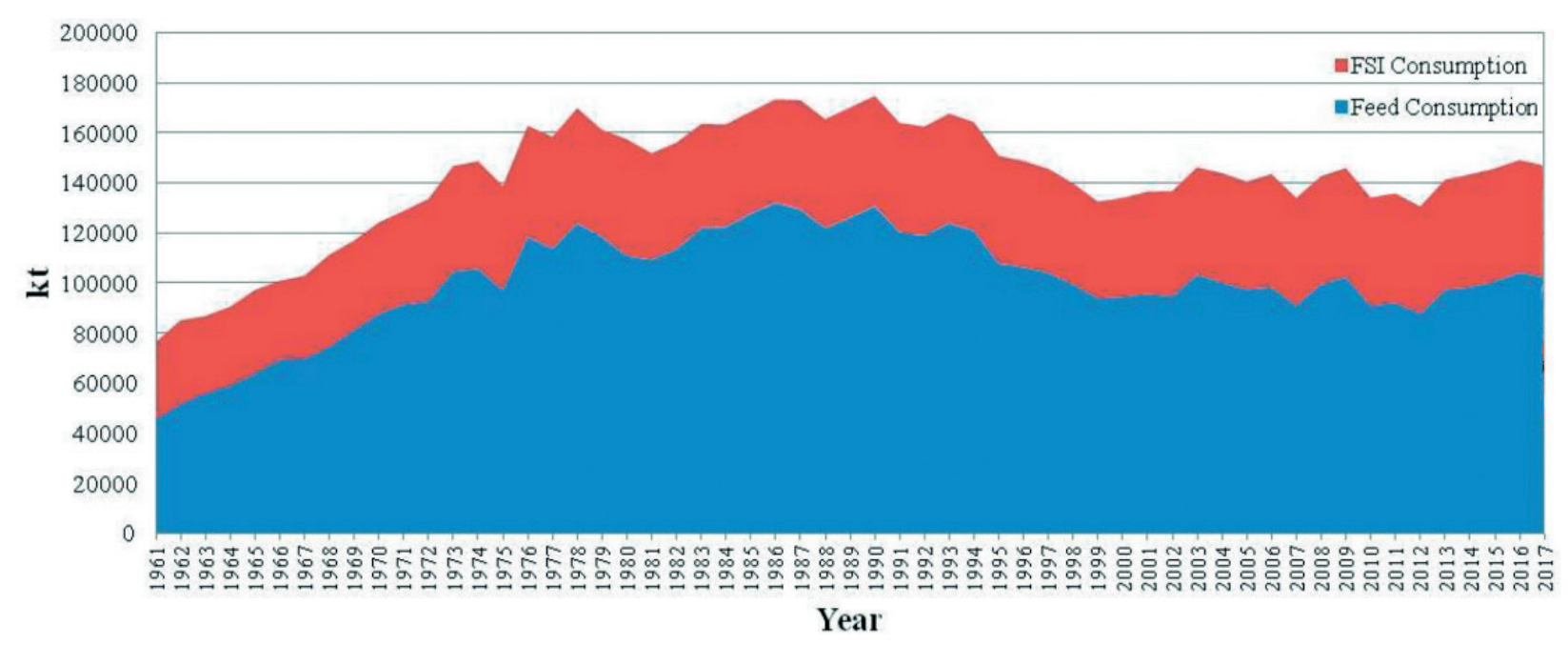

Figure 8. Trend of world barley feed and FSI consumption (source: [12]).

The trend of world barley consumption is similar to the production (Figure 8). However, in the last years, the robust global demand linked to a low world production has led to a decrease of stocks and consequently an increase of the barley price [18] in all major exporting countries. In 2017, the total barley consumption has been about $147 \mathrm{Mt}$ of which $70 \%$ is used for animal feed and 30\% for manufacturing of malt (primarily used in beer production) and other human food applications.

\section{Barley uses}

\subsection{Barley grain main characteristics}

Cultivated barley is one of 31 Hordeum species, belonging to the tribe Triticeae, of the grass family Poaceae also known Gramineae. It is an annual, self-pollinating, diploid species [10, 20].

Barley is differentiated into couplet and polistic. The former is characterized by larger, higherquality seeds, used above all in the production of beer, while the latter are distinguished in tetrastic barriers (four rows) and exquisite bars (six rows).

Depending on the variety, it is also possible to distinguish hulled barley that preserve the glume adhering to the caryopsis, from hull-less barley (or naked barley) that lose the glumes after the threshing. Generally, hulled barley is intended for the production of malt while the hull-less one is used for feed, food, fermented, and unfermented beverages. For this type of barley, there is a particular interest also in new applications: as a whole-grain ingredient in value-added products, as bran and flour in several food applications [21].

All parts of the plant are generally used: fruit kernels, spike, whole plant for ensilage, and straw.

Barley grains are larger and more tapered than wheat, generally bright, light yellow, and the color can vary with purple, violet, blue, and black shades due to the different level of anthocyanins [21]. 
In the caryopsis, the main parts of the kernel are husk, pericarp, testa, aleurone layer, endosperm, and embryo. Husk and pericarp consist primarily of cellulose, hemicellulose, lignin, and lignan, the major constituents of insoluble fibers but also of minerals. The testa is composed of cellulose while the aleurone layer consists of protein-rich cells. The endosperm is a starchy mass in a protein matrix and the embryo is rich in proteins, lipids, and ash [22].

Grain barley chemical composition is strongly influenced by environmental and genetic factors. This last aspect mainly concerns the hulled and hull-less varieties which also have different uses.

In general, the composition of wholegrain barley consists of approximately $70 \%$ starch, $10-20 \%$ protein, $5-10 \% \beta$-glucan (with values up to $20 \%$ for some cultivars), $2-3 \%$ free lipids, and approximately $2.5 \%$ minerals, with the total dietary fiber ranging from 11 to $34 \%$ and soluble dietary fiber being within 3-20\% [1]. Barley kernels naturally contain many bioactive compounds localized in different parts of the kernel, including $\beta$-glucans, lignans, tocotrienols, folate, fructans, phytosterols, polyphenols, policosanol, phytates, pentosans, and arabinoxylans, which play numerous biological activities (prebiotic, probiotic, antioxidant, hypoglycemic, hypocholesterolemic, a reduction of cardiovascular disease, colon cancer, and neural tube defects), and with growing awareness of the need for healthy eating, they can be used as ingredients for the development of functional foods [23]. The last decade saw an increasing interest for this plant mainly due to its health and nutritional benefits [24]. In fact, consumers are even more conscious that food may contribute to also improve their psychophysical well-being $[25,26]$ Therefore, the food production and market have to be oriented to this type of products, contributing to the customer satisfaction. It is in this context that consumers increasingly appreciate functional food, a food intending to affect one or more functions of the body in a positive way, in a way that is relevant and to improve the health and well-being and/or reduce the risk of a disease [27, 28]. There are different types of functional foods and diverse approaches to obtain them. A functional food can be a natural food (e.g., food grains, cereals, wholemeal flours, etc.) or it can be obtained by processing a food utilizing different chemical or biological technologies [29]. Among these different possibilities, cereals are ideal to be used in transmitting compounds and substances with bioactive and dietary properties because, meeting consumer's favor, they are widely and frequently included in our dairy diet. In particular, barley (H. vulgare L.) is an excellent source of dietary fiber and a functional food ingredient such as beta-glucan $[1,2]$.

\subsection{Barley for feed}

As currently mentioned above, approximately $75-80 \%$ of global barley production is used as animal feed, $20-25 \%$ as malting, $2-5 \%$ for human food, and the remaining part in biofuel industry (bioethanol production) [1,30].

In 2017, EU was the main utilizer of barley feed with $40.5 \mathrm{Mt}$ followed by Russia (12.3 Mt), Canada (8.8 Mt), and Turkey (6.5 Mt) and Saudi Arabia (6.3 Mt, almost totally imported) [12] (Table 4).

The main reason of its large use in feed industry is essentially due to its great adaptability to a large variety of pedo-climatic conditions, making it available where other cereals are not and its nutritional value. The use of barley as feed depends on its chemical composition which is 


\begin{tabular}{lrr||lrr}
\hline \multirow{2}{*}{ Countries } & \multicolumn{2}{c||}{ Barley uses } & \multirow{2}{*}{ Countries } & \multicolumn{2}{c}{ Barley uses } \\
& Feed & \multicolumn{1}{c}{ Food } & & Feed & Food \\
\hline EU-25 & 40509000 & 15636000 & Marocco & 1739000 & 870000 \\
Russia & 12343000 & 4944000 & China & 1656000 & 425000 \\
Canada & 8893000 & 1553000 & Japan & 1362000 & 300000 \\
Turkey & 6584000 & 809000 & Algeria & 943000 & 293000 \\
Saudi Arabia & 6326000 & 12000 & Tunisia & 883000 & 58000 \\
Ukraine & 4631000 & 1531000 & South Africa & 203000 & 153000 \\
Iran & 3737000 & 261000 & Taiwan & 68000 & 31000 \\
Australia & 2924000 & 961000 & South Korea & 30000 & 364000 \\
\hline
\end{tabular}

Source: [31].

Table 4. Barley feed and food use in different countries (2016).

strongly influenced by cultivar and where and how it is harvested. Barley protein content, for instance, is very much dependent on the harvest practices and differs with growth conditions, particularly with the rate and timing of nitrogen fertilization [6, 32]. Furthermore, the good content of starch and protein in the grain (respectively, equal to $50-70 \%$ and $10-20 \%$ on dry matter base) makes barley a suitable energy source in ruminant and non-ruminant livestock, poultry, and fish [33].

Barley, compared with corn, shows an almost similar starch percentage but a higher content of total crude protein (respectively, equal to 10-20 and $8.8 \%$ on dry matter base), a higher value of essential amino acids such as lysine (respectively, equal to $0.43-0.21 \%$ on dry matter base), and almost double tryptophan amount. The average barley contents of neutral detergent fiber (NDF) and acid detergent fiber (ADF) are equal to 18 and 6-7\%, respectively. The latter values are higher than corn (NDF 10.8\%, ADF 3\%), wheat (NDF 11.8\%, ADF 4\%), and sorghum (NDF $16.1 \%$, ADF 7-9\%) [30,34]. The evaluation of NDF and ADF is important because it is related to the animal ability to digest them and to the feed efficiency use. Fiber main fraction is in hull (13\%); dehulling practice is not suitable for feed utilization because the seeds are fused to the hulls by a cementing substance hard and expensive to remove. Barley is rich in potassium $(0.57 \%)$ and vitamin A but poor or without vitamin C and B12. Barley contains a relatively high concentration of $\beta$-glucans, compared with other grains ranging from 3.9 to $4.9 \%$ (reaching a concentration equal to $8-10 \%[35,36]$. $\beta$-glucan content is an important parameter to evaluate, mostly in monogastric animals diet, because they act as anti-nutritional factors, reducing feed compound digestibility. In poultry nutrition, for instance, they have negative effects in both growth and feed efficiency but, adding exogenous enzymes such as $\beta$-glucanase, an improvement in bird performance is recorded [37]. The main products utilized in barley feed animal diet are (1) whole or minimal processed barley grain, (2) whole plant forage, (3) malt-based alcoholic beverage by-products, and (4) and milling ones. The first is largely used in cattle diet but, to improve the feed efficiency, minimal mechanical treatments are required. The fibrous hull of barley grain makes the kernels no totally "broken" during the mastication, and mechanical processes are needed. Dry rolled or grounded barley are the most diffused and the less expensive ones. During this treatment, the particle size is important to control because 
smaller they are, higher the fermentation is in rumen, higher the decrease in feed efficiency. Of course, variation in cattle barley wholegrain feedlot nutritional values depends on the animal's ability to masticate, digest, and adsorb them. There is no specific quality restriction to use barley grain in animal feed industry. Often, malting barley is destined to feed industry because there has been damage during agricultural phase or it has not met the quality level required by malting and brewing industries or due to market or price variations. Barley plants are used for forage, pasture, or hay, and their composition and quality mostly vary according to the harvested stage. Straw remaining after grain harvesting is a good fiber source for ruminant or can be used for animal bedding. On average, whole plant and straw ADF is equal to $345 \mathrm{~g} / \mathrm{kg}$ on dry mass and $590 \mathrm{~g} / \mathrm{kg}$ on dry mass, respectively, and NDF is $563-568 \mathrm{~g} / \mathrm{kg}$ on dry mass and $725 \mathrm{~g} / \mathrm{kg}$ on dry mass [30]. It has been a long time since byproducts of malting and brewing industries are used in animal feed. Their quantity and quality depend on technologies applied and barley varieties utilized. Table 5 shows the chemical composition of main products (grain, whole plant, and straw) and by-products obtained from mainly brewer and milling industries useful and utilized in barley feed.

\subsection{Barley for food}

Barley's versatility as food is well known across the world, and it is historically acknowledged. Although barley has remained a major food source for some geographical areas [14, 32], it may be considered relatively underutilized with regard to its potential use as an ingredient in processed human foods. The quantity of barley used for food (excluding the beverage sector) is still very small considering its high nutritional value. The barley grain has a chemical composition extremely useful for the organism: low fat, complex carbohydrates, balanced protein level, a good presence of vitamins, minerals, antioxidants, insoluble, and soluble fiber [2]. The current appreciation of barley as a food source is due quite to its potential health benefits. As a matter of fact, in the past, barley foods had been considered as health-promoting and strength-enhancing. Subsequently, as already underlined, the diffusion of wheat for producing bread and other baked foods has taken over barley's use as food. However, recently, this grain has been reevaluated as having significant benefits in human health functions such as cholesterol-lowering, blood sugar control, and colon health [38, 39, 40, 1]. Table 6 shows the major bioactive compounds, its localization in the kernel, and health benefits.

\begin{tabular}{lcccc}
\hline & $\begin{array}{c}\text { Crude } \\
\text { ash }\end{array}$ & $\begin{array}{c}\text { Crude } \\
\text { protein }\end{array}$ & $\begin{array}{c}\text { Crude } \\
\text { fat }\end{array}$ & $\begin{array}{c}\text { Crude } \\
\text { fiber }\end{array}$ \\
\hline Grain & 23 & 115 & 570 & $110-340$ \\
Whole plant & $75-188$ & $67-120$ & $29-39$ & $356-568$ \\
Straw & $64-75$ & $38-44$ & $17-19$ & $420-438$ \\
Hulls & 71 & 85 & 44 & 276 \\
Maltsters sprout and hulls & 66 & 296 & 10 & 164 \\
Milling process & $43-71$ & $138-111$ & $34-37$ & $81-209$ \\
Brewers grains & 49 & 244 & 79 & 177 \\
Brewers yeast & 85 & 530 & 20 & 15 \\
\hline & & & & \\
Sources: elaboration on $[1,30,34]$. & & & &
\end{tabular}

Table 5. Chemical composition of main products and by-products utilized in barley feed ( $\mathrm{g} / \mathrm{kg}$ on dry mass). 


\begin{tabular}{|c|c|c|}
\hline Compound & Location & Activity \\
\hline Beta-Glucans & endosperm/a leuronic layer & cholesterol-lowering/hypoglyce mic \\
\hline Tocopherols & embryo/a leuronic layer & antioxidant/choles terol-lowering \\
\hline Tocotrienols & embryo/a leuronic layer & antioxidant/cholesterol-lowering \\
\hline Folate & aleuronic layer/embryo & $\begin{array}{l}\text { reduction of neural tube's defects/reduction } \\
\text { of cardiovascular risks }\end{array}$ \\
\hline Phytosterols & embryo/aleuronic layer & cholesterol-lowe ring \\
\hline Polyphenols & pericarp & antioxidant \\
\hline Phytates & pericarp & reduction of colon cancer \\
\hline Policosanol & pericarp & choleste rol-lowe ring \\
\hline Pentosans & pericarp & choleste rol-lowe ring \\
\hline Arabinoxylans & pericarp & cholesterol-lowe ring \\
\hline Lignans & pericarp/aleuronic layer & $\begin{array}{l}\text { reduction of cardiovascular risks/reduction } \\
\text { of malignancies }\end{array}$ \\
\hline Alkylresorcinols & pericarp & antioxidant \\
\hline
\end{tabular}

Source: elaboration on [23].

Table 6. Compounds with biological activity in barley caryopsis.

According to [14] the quite high content of $\beta$-glucan found almost exclusively in oats and barley contributes to heart disease prevention for people who regularly eat these cereals. In fact, numerous clinical trials show barley's equal or superior value as a hypocholesterolemic food compared to oats contributing to reducing the risk of coronary heart diseases. This compound has also a positive action to the bowel function. $\beta$-glucan with the resistance starch fermenting in the large intestine produces short-chain fatty acids especially butyrate and propionate. These fatty acids provide many benefits to the intestine such as energy for epithelial cells that contribute to produce a healthy colonic mucosa [41].

Moreover, the typology of carbohydrates present in the barley seed can contribute to reducing or stabilizing the progression of diabetes disease. This characteristic was already known by ancient Indian physicians some 2400 years ago which used barley to stabilize type 2 diabetes [42].

In the food industry, barley may be blended into many food products at various levels, adding texture, flavor, aroma, and nutritional value to products [43, 44].

Barley undergoes treatments/processes before it can be used in the food sector. The diverse operations modify the chemical composition of the kernel due to the significant differences in the anatomy and composition of the various parts of the same.

This determines a variation in the nutritional value of the kernel and a potential different product range [14]. Figure 9 shows a simplified schematization of the main products and co-products derived from the treatments undergone by the barley.

Whole barley grain is mostly used for feeding animals, whereas for food purposes, it is mainly used as a dehulled grain or high fiber content products. Commercial products derived from wholegrain include barley flakes, grits, and flour. 


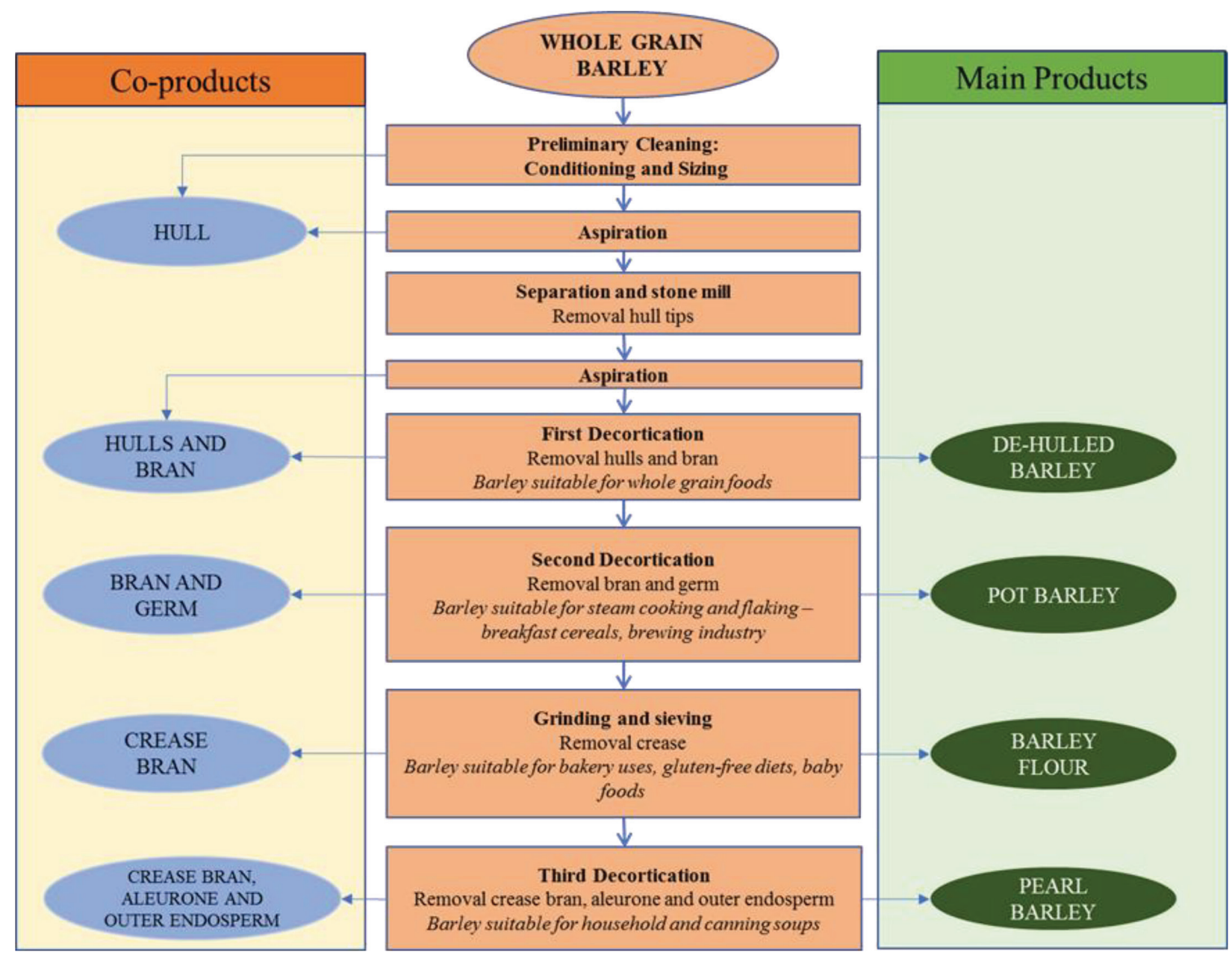

Figure 9. Main products and co-products derived from barley milling process (source: personal author's elaboration).

Food produced from barley is a good source for many nutrients such as protein, fiber, minerals, and B-vitamins [30].

For this purpose, barley grain is first abraded to produce pot or pearled barley and may be further processed into grits, flakes, and flour.

The most common method of processing hulled barley is pearling, which consists of the gradual removal of the outer tissues of the kernel by abrasion. As a result, pot and pearl barley are not considered wholegrains since they are high in $\beta$-glucan content. The hull represents about $10-13 \%$ of the dry weight of the kernel, but the commercial pearling method involves removing more than the hull in order to produce a white-colored, quick-cooking product. Pearling allows barley to have a longer shelf life since the lipid fraction, phenolic compounds, and enzymes contained in the germ are removed. These molecules cause rancidity and darkness barley. About $15 \%$ of the outer layers are eliminated in pot barley, whereas in pearl barley, more than $45 \%$.

Pot and pearl barley are not considered wholegrain because the bran layer and germ are removed. They are also used to make porridge, pie fillings, as an alternative to rice, pasta, or potatoes. Barley flakes are used as an ingredient in muesli or breakfast cereals. 
Cooked pearled barley is used in the preparation of many traditional dishes and also used to produce miso, barley tea, and rice extender in the Japanese market.

Barley flour, prepared from pearled grain through hammer milling or roller milling, can easily be used to produce bread, flat breads (pitas, tortillas, and chapatis), cakes, muffins, cookies, noodles, and extruded snack foods [14, 43,44]. Barley flour can replace all or part of the wheat flour in a wide assortment of bakery products such as, for instance, pasta and noodles.

The use of barley starch is also interesting for the food industry, where it is used as sweetener and binder. In the brewing industry, barley starch is used, together with barley malt, in the production of beer.

Barley for malt and beverages. The best known and most widespread use of barley for food purposes is related to the production of malt that is primarily used in the brewing industry, alcoholic and non-alcoholic beverages. Barley malt is mainly used for beer production while smaller amounts are used by the whisky distilling industry and by bakeries [25].

Barley malts, malt extracts, and syrups are used in small amounts in food products to improve some organoleptic characteristics such as flavor and color, for breakfast cereals, fermented and non-fermented bakery products (e.g., crackers, cookies, and muffins).

Malt extract is a source of soluble sugars, protein, and amylase in the dough and promotes the activity of yeast for better bakery products for texture, volume, etc.

The history of alcoholic drinks including beer goes back to at least 8000 years ago in the Middle East and in Egypt [14, 45]. Barley is used to make most beers because its carbohydrates are particularly well suited for malting. The malting process breaks down carbohydrates into sugars which provide unique flavors and fuel for fermentation. Barley can also be used to make whiskey, quite popular in Ireland and Scotland.

Starch fermentation products are also distilled to pure grain alcohol for vodka-type products as well as industrial ethanol that is sold mainly to the pharmaceutical industry.

Modest quantities of non-alcoholic drinks based on barley and malt are consumed in various parts of the world. A non-exhaustive list of non-alcoholic beverages based on barley is as follows:

1. Barley infusion: coffee substitute (contains no caffeine), obtained from toasted and ground grains, lyophilized or in pods prepared for espresso machines; barley coffee is very popular in Europe particularly in Italy.

2. Barley water: a drink that is made by boiling whole or pearled barley and then flavoring with various fruits. It is a flavorful drink that is enjoyed similar to soft drinks with healthy properties; barley water is used as a dairy substitute for drinks such as smoothies or hot chocolate, or to replace milk on breakfast cereals.

3. Barley tea is common in Asian countries (called mugicha) and is made by lightly roasting barley and then steeping in hot water.

4. Malted beverage: there are also various malted beverages available, often in the form of "malty milk" in which malt extract is blended with milk. 


\subsection{Other uses of barley}

In this paragraph, both new technologies still under study or pre-commercial phase and niche uses of barley that could be developed in the near future are briefly presented. For instance, barley grain is currently utilized in United States of America and in European Union in bioethanol production when the cheapest starch sources such as corn or wheat are not available or a surplus of barley production is recorded [46, 47]. However, the possibility to utilize barley residues or leftover barley by-products (e.g. hulls and mostly dried distillers grain - DDGS) as sources in bio-energy industry is under study. So, hydrothermal liquefaction technology could be useful to obtain bio-oil for transport system or energy sector to produce heat and/or electricity [48]. Moreover, the potential exploitations of barley in non-feed and food fields are numerous and are strictly linked to barley composition, structure, and physicochemical properties of a single component of the plant. For example, the presently growing interest is focused on barley straw use as an alternative non-wood raw material in pulp and paper industry. Paper made from this agriculture residue presents great potential, in terms of paper sheet quality, compared with some wood species much commonly used such as $P$. sylvestris and E. camaldulensis $[49,50]$. Moreover, the high concentration of biocompounds in barley grain and distillery and brewery byproducts (such as phenolics, vitamin $\mathrm{E}$ and $\beta$-glucan, sterols, fatty acids, and bioactive peptides) makes barley a potential source of row material in pharmaceutical and cosmetic industries. Also, lactic acid, xylitol, and microbial enzyme are products obtainable from barley and useful in different industrial sectors [51]. Barley collagen, for instance, is considered a good and profitable collagen vegetal source for cosmetic industry [52]. Furthermore, barley starch shows a suitable attitude to be modified, becoming an appropriate row material for numerous pharmaceutical applications or in the production of biodegradable materials useful in food packing industry $[53,54]$.

Finally, the interesting use is barley straw as an inhibitor for the growth of algae to preserve water resources from algae proliferation $[55,56]$. This new technology could help substitute the chemical products contributing to reduce the environmental impact of water treatment process.

Barley, as already underlined, has developed during its millennial evolution some interesting characteristics, allowing its diffusion and adaptability in a wide range of geographical locations and climatic conditions. This aspect is particularly interesting in an era of climate change whose effects are also reflected in agricultural production. In the recent years, there have been a significant and increasing number of studies on the effect of climate change on agriculture [57] through the use of specific models and software [58]. Climate change is one of the major concerns related to food supply for the increasing population. It has already generated significant impacts on the availability of resources, water, and food production. It is one of the most significant factors influencing crop production [59]. In fact, it affects yield and yield quality due to impacts on crop physiology and in alterations in nutrient mineralization; barley for its characteristics, even in adverse climatic conditions, could represent the right answer to the greater demand for food, feeds, etc., in a strongly dynamic world context [60]. 


\section{Conclusions}

Barley represents one of the ancient grain crops cultivated and used worldwide. Thanks to its high adaptability, this plant grows in different global climates where other cereals (i.e., maize, wheat, and rice) do not live such as in arctic and subarctic zone to subtropical region. This work has presented some interesting aspects of this grain, regarding especially the international market trend and use. The principal results from this overview are the following:

1. in the last 70 years, the harvesting area is decreased especially in the major barley production countries such as Russia (including all the countries from former USSR), United States, India, and China, probably due to the low income deriving from this culture with respect to others such as maize. However, this situation has been balanced by the yield improving, changed from about $1.4 \mathrm{t} / \mathrm{ha}$ in the years 1960 to $3 \mathrm{t} / \mathrm{ha}$ in 2017, which has pushed the barley production from almost 79 (1960) to $141 \mathrm{Gt}(2017)$;

2. currently, the leader, in terms of production and area dedicated, is EU followed by Russian Federation, Ukraine, Australia, and Canada. In particular, Germany and France are the first and second European barley producers followed by Spain and United Kingdom which contribute more than $35 \%$ of the total EU production;

3. regarding the barley consumption in 2017 , it was about $147 \mathrm{Mt}$, of which $70 \%$ is used for animal feed and $30 \%$ principally for the production of beer ingredient (malt) and a little quantity for other human food applications;

4. in the recent years, the high barley demand on the global markets not balanced by the world production has led on one side to a decrease of stocks in many countries producer and on the other side an increase of the barley price. This situation could get worse in the future due to the increase of its request in the global markets (principally China);

5. finally, the principal uses of this grain is to produce feed and beer, although recently it has been revaluated as food in the human diet, thanks to its significant benefits on the human health such as cholesterol lowering, blood sugar control, and improving of the colon health.

\section{Author details}

Caterina Tricase ${ }^{1 *}$, Vera Amicarelli ${ }^{2}$, Emilia Lamonaca $^{1}$ and Roberto Leonardo Rana ${ }^{1}$

*Address all correspondence to: caterina.tricase@unifg.it

1 Department of Economics, University of Foggia, Foggia, Italy

2 Department of Economics, Management and Business Law, University of Bari, Bari, Italy 


\section{References}

[1] Sullivan P, Arendt E, Gallagher E. The increasing use of barley and barley by-products in the production of healthier baked goods. Trends in Food Science \& Technology. 2013;29:124-134. DOI: 10.1016/j.tifs.2012.10.005

[2] Baik BK, Ullrich SE. Barley for food: Characteristics, improvement, and renewed interest. Journal of Cereal Science. 2008;48:233-242. DOI: 10.1016/j.jcs.2008.02.002

[3] Clark HH. The origin and early history of the cultivated barleys. A botanical and archaeological synthesis. In: British Agricultural History Society Editor. London: The Agricultural History Review; 1967. pp. 1-18

[4] von Bothmer R, Komatsuda T. Barley origin and related species. In: Ullrich SE, editor. Barley: Production, Improvement, and Uses. Oxford: Wiley-Blackwell; 2011. pp. 14-62. DOI: $10.1002 / 9780470958636 . c h 1$

[5] Badr A, Sch KMR, El Rabey H, Effgen S, Ibrahim HH, Pozzi C, Rohde W, Salamini F. On the origin and domestication history of barley (Hordeum vulgare). Molecular Biology and Evolution. 2000;17:499-510. DOI: 10.1093/oxfordjournals.molbev.a026330

[6] Arendt E, Zannini E. Cereal Grains for the Food and Beverage Industries. Philadelphia: Woodhead Publishing; 2013. 512p

[7] FAO-FAOSTAT (Food and Agriculture Organization of the United Nations). Crops [Internet]. 2018. Available from: www.fao.org/faostat/en/\#data/QC [Accessed: March 19, 2018]

[8] Garstang JR, Spink JH, Suleimenov M, Schillinger WF, McKenzie RH, Tanake DL, Ceccarelli S, Grando S, Paynter BH, Fettell NA. Cultural practices: Focus on major barley-producing regions. In: Ullrich SE, editor. Barley: Production, Improvement, and Uses. Oxford: Wiley-Blackwell; 2011. pp. 221-281. DOI: 10.1002/9780470958636.ch1

[9] Ingvordsen CH, Backes G, Lyngkjær MF, Peltonen-Sainio P, Jensen JD, Jalli M, Jahoore A, Rasmussen M, Mikkelsen TN, Stockmarr A, Jørgensen RB. Significant decrease in yield under future climate conditions: Stability and production of 138 spring barley accessions. European Journal of Agronomy. 2015;63:105-113

[10] KlingJG, Hayes PM, Barley USE. Genetics and breeding. In: Wrigley C, Corke H, Walker C, editors. Encyclopedia of Grain Science. Oxford: Elsevier; 2004. pp. 27-37

[11] Tricase C, Lamonaca E, Ingrao C, Bacenetti J, Giudice AL. A comparative life cycle assessment between organic and conventional barley cultivation for sustainable agriculture pathways. Journal of Cleaner Production. 2018;172:3747-3759. DOI: 10.1016/j. jclepro.2017.07.008

[12] USDA/FAS (United States Department of Agriculture, Foreign Agricultural Systems). Market and Trade Data/PSD Online/Custom Query [Internet]. 2018a. Available from: https://apps.fas.usda.gov/psdonline/app/index.html\#/app/advQuery [Accessed: March 10, 2018] 
[13] Newton AC, Flavell AJ, George TS, Leat P, Mullholland B, Ramsay L, Revoredo-Giha C, Russell J, Steffenson BJ, Swanston JS, Thomas WTB, Waugh R, White PJ, Bingham IJ. Crops that feed the world 4. Barley: A resilient crop? Strengths and weaknesses in the context of food security. Food Security. 2011;3:141-178. DOI: 10.1007/s12571-011-0126-3

[14] Ullrich SE. Significance, adaptation, production, and trade of barley. In: Ullrich SE, editor. Barley: Production, Improvement, and Uses. Oxford: Wiley-Blackwell; 2011. pp. 3-13. DOI: $10.1002 / 9780470958636 . c h 1$

[15] Griffey C, Brooks W, Kurantz M, Thomason W, Taylor F, Obert D, Moreau R, Flores R, Sohn M, Hicks K. Grain composition of Virginia winter barley and implications for use in feed, food and biofuels production. Journal of Cereal Science. 2010;51:41-49. DOI: 10.1016/j.jcs.2009.09.004

[16] Ajanovic A. Biofuels versus food production: Does biofuels production increase food prices? Energy. 2011;36:2070-2076. DOI: 10.1016/j.energy.2010.05.019

[17] USDA (United States Department of Agriculture). Saudi Arabia Grain and Feed Annual 2017 [Internet]. 2017. Available from: https://gain.fas.usda.gov/Recent\%20GAIN\%20 Publications/Grain\%20and\%20Feed\%20Annual_Riyadh_Saudi\%20Arabia_4-2-2017.pdf [Accessed: March 10, 2018]

[18] USDA/FAS (United States Department of Agriculture, Foreign Agricultural Systems). Grain: World Market and Trade-Barley Prices Fail to Curb China's Demand [Internet]. 2018b. Available from: http://uga.ua/wp-content/uploads/grain-market-03-08-2018.pdf [Accessed: March 10, 2018]

[19] IFM (International Monetary Fund). IMF Primary Commodity Prices [Internet]. 2018. Available from: https://www.imf.org/external/np/res/commod/External_Data. xls [Accessed: April 21, 2018]

[20] Kant L, Amrapali S, Babu BK. Barley. In: Upadhyaya MSH, editor. Genetic and Genomic Resources for Grain Cereals Improvement. San Diego: Academic Press; 2016. pp. 125-157. DOI: 10.1016/B978-0-12-802000-5.00003-4

[21] Arendt EK, Zannini E, editors. Cereal Grains for the Food and Beverage Industries. Cambridge: Woodhead Publishing; 2013. p. 485

[22] Izydorczyk MS, Dexter JE. Barley: Milling and processing. In: Wrigley C, Corke H, Walker C, editors. Encyclopedia of Grain Science. Oxford: Elsevier; 2004. pp. 57-68

[23] Marconi E. Alimenti funzionali e cereali: 30 anni di ricerca in Unimol [Internet]. 2012. Available from: oldweb.unimol.it/unimolise/allegati/54691/prolusione\%20prof\%20emanuele\%20marconi.pdf [Accessed: March 10, 2018]

[24] Ames NP, Rhymer CR. Issues surrounding health claims for barley. The Journal Of Nutrition. 2008;138:1237S-1243S

[25] Menrad K. Market and marketing of functional food in Europe. Journal of Food Engineering. 2003;56:181-188 
[26] Roberfroid MB. An European consensus of scientific concepts of functional foods. Nutrition. 2000;16:689-691

[27] Doyon M, Labrecque JA. Functional foods: A conceptual definition. British Food Journal. 2008;110:1133-1149

[28] EUFIC (European Food Information Council). Functional Foods [Internet]. 2006. Available from: www.eufic.org [Accessed: March 10, 2018]

[29] Sirò I, Kápolna E, Kápolna B, Lugasi A. Functional food. Product development, marketing and consumer acceptance-A review. Appetite. 2008;51:456-467

[30] OECD (Organisation for Economic Co-operation and Development). Environmental Health and Safety Publications, Series on the Safety of Novel Foods and Feeds, No. 12, Consensus Document on Compositional Considerations for New Varieties of Barley (Hordeum vulgare L.): Key Food and Feed Nutrients and Anti-nutrients [Internet]. 2004. Available from: https://www.oecd.org/env/ehs/biotrack/46815246.pdf [Accessed: March 10, 2018]

[31] USDA (United States Department of Agriculture). Feed Grains: Yearbook Tables [Internet]. 2018. Available from: https://www.ers.usda.gov/data-products/feed-grainsdatabase/feed-grains-yearbook-tables/\#Zipped\%20CSV\%20files [Accessed: April 27, 2018]

[32] Qi JC, Zhang GP, Zhou MX. Protein and hordein content in barley seeds as affected by nitrogen level and their relationship to beta-amylase activity. Journal of Cereal Science. 2006;43:102-107. DOI: 10.1016/j.jcs.2005.08.005

[33] Kellems RO, Church DC, editors. Livestock Feeds and Feeding. 6th ed. Upper Saddle River USA: Pearson Education; 2010. 711p

[34] Nikkhah A. Barley grain for ruminants: A global treasure or tragedy. Journal of Animal Science and Biotechnology. 2012;3:1-9

[35] Zhang G, Chen J, Wang J, Ding S. Cultivar and environmental effects on (1-3,1-4)- $\beta$-Dglucan and protein content in malting barley. Journal of Cereal Science. 2001;34:295-301. DOI: $10.1006 /$ jcrs.2001.0414

[36] Izydorczyk MS, Storsley J, Labossiere D, Macgreggor AW, Rossnagel BG. Variation in total and soluble b-glucan content in hulless barley: Effects of thermal, physical, and enzymic treatments. Journal of Agricultural and Food Chemistry. 2000;48:982-989

[37] Jacob J, Pescatore J. Barley $\beta$-glucan in poultry diets. Annals of Transnational Medicine. 2014;2:20. DOI: 10.3978/j.issn.2305-5839.2014.01.02

[38] Rahaie S, Gharibzahedi SMT, Razavi SH, Jafari SM. Recent developments on new formulations based on nutrient-dense ingredients for the production of healthy-functional bread: A review. Journal of Food Science Technology. 2014;51:2896-2906. DOI: 10.1007/ s13197-012-0833-6

[39] Bird AR, Vuaran MS, King RA, Noakes M, Keogh J, Morell MK, Topping DL. Wholegrain foods made from a novel high-amylose barley variety (Himalaya 292) improve indices 
of bowel health in human subjects. The British Journal of Nutrition. 2008;99:1032-1040. DOI: $10.1017 / S 000711450783902 X$

[40] Li J, Kaneko T, Qin LQ, Wang J, Wang Y. Effects of barley intake on glucose tolerance, lipid metabolism, and bowel function in women. Nutrition. 2003;19:926-929. DOI: 10.1016/S0899-9007(03)00182-5

[41] Topping DL, Morell MK, King RA, Li Z, Bird AR, Noakes M. Resistant starch and health-Himalaya 292: A novel barley cultivar to deliver benefits to consumers. StarchStärke. 2003;55:539-545

[42] Ajgaonker SS. Diabetes mellitus as seen in the ancient ayurvedic medicine. In: Bajaj JS, editor. Insulin and Metabolism. Bombay: Association of India. 1972. pp. 13-20

[43] Newman CW, Newman RK. A brief history of barley foods. Cereal Foods World. 2006;51:4-7. DOI: 10.1094/CFW-51-0004

[44] Baik BK, Newman CW, Newman RK, Ullrich SE. Food uses of barley. In: Ullrich SE, editor. Barley: Production, Improvement, and Uses. Oxford: Wiley-Blackwell; 2011. pp. 532-562. DOI: 10.1002/9780470958636.ch1

[45] Schwar P, Li Y. Malting and brewing uses of barley. In: Ullrich SE, editor. Barley: Production, Improvement, and Uses. Oxford: Wiley-Blackwell; 2011. pp. 478-521. DOI: 10.1002/9780470958636.ch1

[46] USDA (United States Department of Agriculture). EU -28 EU biofuels annual 2017 [Internet]. 2017. Available from: https://gain.fas.usda.gov/Recent\%20GAIN\%20Publications/ Biofuels\%20Annual_The\%20Hague_EU-28_6-19-2017.pdf [Accessed: May 12, 2018]

[47] Nghiem NP, Brooks WS, Griffey CA, Toht MJ. Production of ethanol from newly developed and improved winter barley cultivars. Applied Biochemistry and Biotechnology. 2017;182:400-410

[48] Zhu Z, Rosendahl L, Toor SS, Yu D, Chen G. Hydrothermal liquefaction of barley straw to bio-crude oil: Effects of reaction temperature and aqueous phase recirculation. Applied Energy. 2015;137:183-192

[49] Gonzalo A, Bimbela F, Sánchez JL, Labidi J, Marín F, Arauzo J. Evaluation of different agricultural residues as raw materials for pulp and paper production using a semichemical process. Journal of Cleaner Production. 2017;156:184-193. DOI: 10.1016/j. jclepro.2017.04.036

[50] Vargas F, González Z, Rojas OJ, Garrote G, Rodriguez A. Barley straw (Hordeum vulgare) as a supplementary raw material for Eucalyptus camaldulensis and Pinus sylvestris Kraft pulp in the paper industry. Bio Resources. 2015;10:3682-3693

[51] Nigam PS. An overview: Recycling of solid barley waste generated as a by-product in distillery and brewery. Waste Management. 2017;62(Suppl. C):255-261. DOI: 10.1016/j. wasman.2017.02.018 
[52] Avila Rodríguez MI, Rodríguez Barroso LG, Sánchez ML. Collagen: A review on its sources and potential cosmetic applications. Journal of Cosmetic Dermatology. 2018;17: 20-26. DOI: $10.1111 /$ jocd. 12450

[53] Bello-Pérez LA, Agama-Acevedo E, Zamudio-Flores PB, Mendez-Montealvo G, Rodriguez-Ambriz SL. Effect of low and high acetylation degree in the morphological, physicochemical and structural characteristics of barley starch. LWT-Food Science and Technology. 2010;43:1434-1440

[54] Halal SLME, Colussi R, Pinto VZ, Bartz J, Radunz M, Carreno NLV, Guerra Dias AR, da Rosa Zavareze E. Structure, morphology and functionality of acetylated and oxidised barley starches. Food Chemistry. 2015;168:247-256. DOI: 10.1016/j.foodchem.2014.07.046

[55] Joseph D, Boylan DJ, Morris JE. Limited effects of barley Strawon algae and zooplankton in a Midwestern pond. Lake and Reservoir Management. 2003;19:265-271. DOI: $10.1080 / 07438140309354091$

[56] hUallacháin DÓ, Fenton O. Barley (Hordeum vulgare)-induced growth inhibition of algae: A review. Journal of Applied Phycology. 2010;22:651-658. DOI: 10.1007/s10811009-9492-z

[57] Blanco M, Ramos F, Van Doorslaer B, Martinez P, Fumagalli D, Ceglar A, Fernandez FJ. Climate change impacts on EU agriculture: A regionalized perspective taking into account market-driven and adjustments. Agricultural Systems. 2017;156:52-66

[58] Ewert F, Rötter RP, Bindi M, Webber H, Trnka M, Kersebaum KC, Olesen JE, van Ittersum MK, Janssen S, Rivington M, Semenov MA, Wallach D, Porter JR, Stewart D, Verhagen J, Gaiser T, Palosuo T, Tao F, Nendel C, Roggero PP, Bartošova L, Asseng S. Crop modelling for integrated assessment of risk to food production from climate change. Environmental Modelling \& Software. 2015;72:287-303

[59] Kang Y, Khan S, Ma X. Climate change impacts on crop yield, crop water productivity and food security-A review. Progress in Natural Science. 2009;19:1665-1674

[60] Högy P, Poll C, Marhan S, Kandeler E, Fangmeier A. Impacts of temperature increase and change in precipitation pattern on crop yield and yield quality of barley. Food Chemistry. 2013;136:1470-1477 


\title{
Chapter 3
}

\section{Management Practices and Bioproductivity in Grassland of Dry Areas}

\author{
Luis G. Yáñez-Chávez, Aurelio Pedroza-Sandoval, \\ Ignacio Sánchez-Cohen, \\ Miguel A. Velásquez-Valle and \\ Ricardo Trejo-Calzada
}

Additional information is available at the end of the chapter

http://dx.doi.org/10.5772/intechopen.79411

\begin{abstract}
In Mexico, the grassland represents $40.1 \%$ of the total area of the country and it is a source of feed for livestock, although suffers different degrees of degradation due to lack of management and adverse climatic conditions. The problem of the grasslands is complex since it involves diverse type's soils, presence of invasive plants, low success in the establishment of grasses or replanting, high fluctuation in the rainfall distribution, as well as the low capacity of the soil to retain moisture. Among these constraints, the limited availability of soil moisture in arid conditions, makes these areas more fragile to the degradation of the environment which results in low productivity of the grassland. In this chapter, major ecological limitations of the grassland and techniques which improve the soils moisture retention capacity of the grassland especially in moisture deficit areas will be discussed.
\end{abstract}

Keywords: grass, forage productivity, soil moisture, grazing, livestock

\section{Introduction}

Extensive livestock areas are one of the fastest growing sectors in the world compared to other agricultural sectors $[1,2]$. It is also the means of subsistence for millions of people and is a great architect of world agricultural production [3,4]. Livestock is the world's largest user of land resources: rangelands used for grazing and fodder production account for almost $80 \%$ of all agricultural areas [1]. However, in the extensive field, livestock frequently participate in the degradation of large areas of grassland and is a contributing factor to deforestation 
through clearing of the trees to grow grasses for the livestock [1, 4]. In addition, the herds of cattle cause large-scale soil damage, mainly due to overgrazing of the grass, soil compaction and soil erosion [5-7].

Currently, the interest in the efficient use and conservation of grassland has been restarted, due to its importance in animal feed, the integral maintenance of the environment and because it is one of the most threatened ecosystems, mainly due to extensive livestock farming, drought and conversion for the land to cropland $[8,9]$.

The efficiency in the use of the grassland implies the sustainable use of this ecosystem for the feeding of the domestic cattle, without neglecting the natural wildlife and the interaction with the contiguous ecosystems. Grasses are considered as one of the most important sources in low-cost feed for cattle, sheep and goats $[1,10]$. The adequate use of grassland provides economic benefits to the states, livestock areas, producers and final consumers of agricultural products. In spite of the importance of the grassland, in recent years its conservation has been neglected. Hence, excessive animal burden was promoted which favored the reduction in the productive capacity of the ecosystem that resulted in soil erosion and loss of biodiversity [11]. Due to this, the competitiveness of the system has been reduced. In addition, productive efficiency as well as social and economic benefits that are generated from agricultural production in natural grassland had been reduced.

Due to the overgrazing of the grasses by allowing excess number of livestock which is more than the capacity of land the ecosystem of the area has been drastically affected [1]. This has caused a radical change in the floristic composition of the grasslands and a reduction in water permeability of the soil, which increases the runoff and causes an accelerated erosion [12]. The substitution of complex grassland ecosystems for extensive livestock has implied an invaluable ecological cost.

Thus, in the present work we will tackle repasting techniques, integral use of biotic resources, control of the carrying capacity and a better planning on the activity the livestock, the foregoing to minimize the effects of extensive cattle ranching in the grassland ecosystem. In addition, the major findings relevant to the topic especially on the contribution of grasses in the mitigation of the degraded soils in drylands is given emphasis.

\section{The stage of extensive livestock farming, its impact on grassland ecosystems}

From an environmental point of view, the extensive livestock model contributes to the degradation of the territory but in a much lower proportion than the contribution of the intensive and industrial production system. It should be noted that in the extensive exploitation, the aspect that has the most environmental impact is the clearing of the land to allow the growth of grasses. On the other hand, it can also influence the degradation of grassland areas as a result of overexploitation, especially in the arid and semiarid regions where crops and plants take longer to develop. However, due to its distribution in an extensive manner, it could be said that it's negative impact in terms of the emission of contaminating flows or in the 
compaction of the soil is less than the intensive production model. This is due to the fact that being distributed on the land exceeds the load capacity. Moreover, in most cases, authors indicate that rather than contaminating, it implies a load of nutrients and a contribution to the development of that surface $[1,7]$. Therefore, it is necessary to highlight the positive aspects of this type of exploitation to the environment as it is closely linked to the latter. In this line, it is worth highlighting that extensive exploitation contributes in a sustainable way to obtain natural fertilizer [13], control of shrub vegetation [14] and regulate fuel biomass in forest areas [15], as well as preserve the biodiversity [16].

Apparently, the interaction of livestock with the ecosystem is complex and depends on the location and management practices. Extensive livestock production systems are based on the availability of resources locally which dictates the use of alternative sources that reduce opportunity costs. Examples of such resources are crop residues and land under extensive grazing that is unfit for cultivation or other uses [13]. At the same time, in traditional livestock farming systems valuable agricultural inputs are generated which guarantees the close integration of the two production systems.

In particular, genetically conditioned, the grassland evolved to trampling, defoliation and, when they retain sufficient vigor in response to erratic grazing (before the arrival of domestic livestock) and/or controlled (under modern grazing), enter latency, avoiding critical periods, either drought or winter, to vigorously sprout when the temperature and humidity of growth return [1]; their habit of modular growth means that they maintain the proper structure to harvest rains smaller than $5 \mathrm{~mm}$, cover areas of bare soil and, at the same time, trap moving soil in the air or form soil. In this regard [1], the best soils in the arid and semiarid world, currently under agricultural use, were formed by grassland and it is still possible to observe regions with soils of depths from 1 to $2 \mathrm{~m}$ that were grasslands in their most recent history.

It is necessary to delimit, that in a healthy grasses, a density of 60,000 mature tillers per hectare [17]. However, due to frequent overgrazing (not respecting times of abundance and shortage), the vast majority of arid and semiarid grassland had a population of less than 2000 mature tillers per hectare of desirable perennial species [8]. These 2000 tillers are those that resist drought, overgrazing and low temperatures, which leaves large areas of bare soil and solar energy that dissipates heat. Since the forage and other grass products are interpreted by the owner of the grazing area as harvest opportunity, the first to arrive or the one with the most adequate collection tools, takes advantage of the resource before others do it. However, this practice is mostly done without promoting its abundance and without respecting rules of use or without knowing the effect of its long-term activity on the ecosystem.

\subsection{Hubs of controversy in the degradation of grassland due to livestock}

The characteristics that are most recurrent in the grassland of the arid and semiarid zones are the cyclical drought register [18] and the pressure of the land use [19], with an extensive exploitation system. These lead to the overgrazing of the land. In this regard, the degradation of the natural resources of the grassland in arid and semiarid zones as a form of desertification, is the factor that most affects the grassland ecosystem, in which extensive livestock is practiced [20]. 
In arid and semiarid areas, where most of the world's grassland ecosystem is located, grassland intensification is usually not technically viable or profitable. As a result of the weakening of traditional institutions and increased pressure on land, many of them have become open access zones. In these and other grassland based systems, incentives and technologies to improve grassland management are scarce [1]; therefore, the improvement of productivity and potential ecosystem services are lost.

Deforestation caused by overgrazing is a common feature [19]. According to Programa das Nações Unidas para o Meio Ambiente (PNUMA) study in Brazil [21], approximately $20 \%$ of the world's grasses and grassland had suffered some degree of degradation, and this numbers rises to $73 \%$ in arid lands. According to the estimation of the Millennium Ecosystem Assessment, 10-20\% of the grassland is degraded, mainly due to overgrazing [22].

The degradation of the grassland is usually the consequence of the lack of correspondence between the density of livestock and the ability of the grasses to recover from grazing and trampling. Ideally, the land: livestock ratio should be adjusted continuously to the conditions of the grasses especially in dry climates. However, due to the weakness of traditional institutions, the increase in pressure on resources and the number of obstacles that hinder the movement of livestock, such adjustments are usually not possible. This occurs in particular in the case of arid and semiarid communal grazing areas [1]. Among the environmental consequences of grassland degradation soil erosion, vegetation degradation, the release of carbon from organic matter deposits, the reduction of biodiversity and the damage of the water cycle are the major ones.

Degradation due to grazing can be reversed to a certain extent, although the speed of the process and the best techniques for this purpose remain the subject of discussion. Grazing lands can be managed sustainably by virtue of common property systems. However, in cases where common property systems have been divided, excessive grazing is usually observed. The economic argument by which each farmer tries to maximize their personal benefits, when common property systems are divided is clear: maximizing the number of animals per hectare allows the cultivation of more resources for individual benefit. This encourages overexploitation of land resources to the detriment of total productivity.

\subsection{Livestock and grassland: a global perspective}

The different systems of livestock production affect biodiversity in different ways. Extensive systems could accommodate large number of breeds and make use of a huge variety of plant resources such as forages, but their lower productivity could increase the pressure to invade natural habitats to a greater extent.

In general, the effects of livestock on biodiversity depend on the magnitude of these effects or on the degree to which biodiversity is exposed to them, on the sensitivity of biodiversity to livestock and on how it responds to these effects [23].

According to the Millennium Ecosystem Assessment [22], the most important direct causes of the loss of biodiversity and changes in ecosystem services are alterations in the habitat (such as changes in the use of land), climate change, invasive alien species, overexploitation and 
pollution. Cattle contribute directly or indirectly to all these causes of the loss of diversity, both locally and globally.

Normally, the loss of biodiversity is caused by the combination of various processes of environmental degradation [1]. This makes it difficult to isolate the contribution of the livestock sector. Another complication is the multiple phases of the food production chain of animal origin in which the environmental effects take place.

The use of land and the change in land use related to livestock production modify ecosystems that are the habitats of specific species. Cattle contribute to climate change, which in turn has implications for ecosystems and species. The sector also has direct impacts on biodiversity through the transfer of invasive exotic species [11], for example through overgrazing.

\subsection{Alternatives for the conservation of the grassland ecosystem: towards a need for change}

Taking measures towards reducing the effects of extensive livestock production on the ecosystem is important as lack of the action drastically worsen the situation. It is also necessary to balance the demand for animal products with the growing demand for environmental services, such as clean air and water.

One of the measures to counteract the effects of extensive production is the current prices of land, water and fodder resources used in livestock production, since they do not usually reflect the scarcity of these resources [1]. As a consequence, they are abused and the productive process is remarkably inefficient. Environmental protection policies should introduce adequate market prices for the main inputs [19], for example, by introducing water and grazing prices that reflect the total costs. Precisely, the recent development of water markets, in addition to the establishment of prices proportionally more appropriate in some countries, especially those suffering from the shortage of this resource, are measured in the right direction [1].

Good agricultural practices are equivalent to another technique that could reduce the effects of extensive livestock production $[1,24,25]$. This is referred to reduce the use of inputs in the production of forages and in the intensive management of grassland. The integration of technologies and ecological production systems can restore important soil habitats and reduce degradation.

Overgrazing can be reduced by introducing exploitation fees and removing obstacles to mobility in communally owned grasslands. Land degradation can be avoided and reversed through soil conservation methods [26, 27], silvopastoralism [18], better management of grazing systems [20], establishment of limits on uncontrolled burning by producers [23], and the controlled exclusion of livestock from fragile areas [24].

The combination of such local improvements with the restoration or conservation of an ecological structure in the river watershed area could be a good way to reconcile the conservation of the ecosystem function and the expansion of agricultural production [28]. In the extensive agricultural production systems, there is a great difference between current productivity and potential productivity, which indicates that a considerable increase in efficiency can be 
achieved by improving management [29]. However, this is more difficult to achieve in areas with limited resources, which are also ecologically more marginal areas.

In the case of most productive systems, there are improved and efficient production technologies. However, access to relevant information and the ability to select and implement the most appropriate technologies are limiting factors. These limitations can be reduced by managing interactive knowledge, capacity building and informed decision-making in policy, investment, rural development and producer areas [1]. It is necessary to guide technological improvements towards an optimal integrated use of land, water, human beings, livestock and grazing food resources for livestock.

\section{Productive reconversion and management practices in arid land grasses}

The productive reconversion is interpreted as the incorporation of technological changes and processes that contribute to the productivity and competitiveness of the agricultural sector to food security, and to the optimal use of lands through complementary supports and investments $[18,30]$. The objective of the productive reconversion is to promote the establishment of agricultural and forestry production activities in areas of well productive potential and productive aptitude, which are competitive and promote sustainability.

According with the laws in force that regulate the use of natural resources in Mexico, the terms identified and that are related to the reconversion are: technological changes, conversion of crops, productive reconversion and recovery of degraded areas [18]. They show a gradient of technological actions ranging from the most elementary adoption of a technological component, until gradually, reaching an early extreme that is the recovery of degraded areas.

Productive reconversion, considers agronomic criteria, such as the changes of current species by native species or alternative crops that are apt to survive and produce in areas susceptible to conversion.

Regarding grassland management practices in arid lands, it is based on ecological principles where processes of plant succession, condition and composition, density of species and plant communities, areas and species among others are observed [31]. The actions that allow an adequate management of the grassland in the arid and semiarid zones, are priorities when developing programs of resource management for these zones. Likewise, the health of these ecosystems involves other highly relevant efforts [32]. However, when the management actions are not sufficient to maintain the grasses in good condition, the option to induce, through rehabilitation and/or improvement techniques, a gradual recovery of the grassland in order to increase their productivity [20,33].

\subsection{Management of grassland: success studies in arid lands north of Mexico}

The establishment of grassland in soils with physical degradation in areas in arid lands, implies the possibility of obtaining food for the cattle and at the same time improving the 
condition of the land. For the rehabilitation of these areas, it is important to consider grass species that are tolerant to the prevailing environmental conditions. Maintaining moisture in the soil with efficient micro-harvesting systems contributes to the improvement of soil quality, avoiding erosion by wind and rain water trawling. The integration of vegetation covering, as well as the use of moisture retainers, as a way to reduce the high rate of evaporation, key options to be widely adopted. However, so far, they are little explored and hence poorly implemented environment degraded by soil erosion and desertification [34, 35].

\subsubsection{Grasslands in the middle watershed Nazas-Aguanaval: case study San Luis del} Cordero, Dgo

The middle watershed of the Nazas-Aguanaval rivers is a predominantly grassland area that is considered as a semiarid zone. This region registers an environmental deterioration, due to overgrazing by large number of cattle which results in partial loss of vegetation cover and a progressive loss of soil [36]. The major findings of the study at San Luis del Cordero, Durango, Mexico in 2015 with the aim of evaluating different soil moisture retention practices as well as the use of hydrogel and stubbles on the survival and establishment of grass (Bouteloua curtipendula [Michx.] Torr. and Chloris gayana Kunth) are briefly presented below [35].

\subsubsection{Moisture content of the soil}

The moisture content of the soil was significantly $(\mathrm{P} \leq 0.05)$ higher than the control at each depth evaluated when applying hydrogel after the runoff, registering values on average $3.0 \%$ higher, with respect to the control. This effect was diluted, in the later evaluation dates for both depths. Hydrogels offer properties of retention and slow release of water in the soil, either under conditions of immediate or prolonged irrigation, in addition to conserving moisture in the root zone of crops [37]; however, in this study, the properties of the hydrogel were not observed. Other authors highlighted hydrogel applications in buffel grass in arid climates, improved seedling emergence, plant height, dry matter weight and vegetation cover [34]. This positive effect was associated with hydrogels that significantly improved absorption capacity of easily removable water of the soils; although the effectiveness of the gel in improving water retention varies according to the type of soil [38].

Regarding the use of vegetable cover based on corn stubble, the moisture content evaluated at different depths significantly higher $(\mathrm{P} \leq 0.05)$ in $3.2 \%$ on each date of evaluation with respect to where the crop residue was not incorporated. The usable humidity for this type of soil is $18 \%$, given that the CC was $33 \%$ and the PMP $15 \%$. In the treatment without stubble application, it reached values of $16 \%$, very close to the PMP value. In this regard, the use of mulch or crop residue in the production of other crops has been shown with favorable results, such as soybeans and rainfed sorghum, were associated with a higher moisture content in the soil when applying mulch in both crops, mainly in years with irregular rainfall [39]. In addition, other authors indicate that the incorporation of mulch or stubble to crops represents an important cultural practice, since it plays an essential role in the conservation of moisture in the soil; the organic and inorganic coverings, on average, register a higher content of soil moisture for the first active soil layer [40]. 


\subsubsection{Seedling survival}

B. curtipendula and C. gayana had superior survival rate of $84 \%, 6$ weeks after transplanting, although the differences between the two species was not significant. The high percentage of survival might be due to the planting method during the transplanting, since direct sowing of the seed in the field is only $10 \%$ and in some cases $50 \%$ [41]. Values higher than $95 \%$ of establishment in buffel grass had been found when using the transplant method, considered a highly effective sowing method even in soils with limited natural fertility.

The percentage of grass survival was 88.6 and $76.4 \%$ in the hydrogel doses of 20 and $10 \mathrm{~kg} \mathrm{ha}^{-1}$, respectively, but with no significance difference between the two, with a better response tendency in the dose of $20 \mathrm{~kg} \mathrm{ha}^{-1}$, by statistically differentiating from the control. The survival percentage was significantly higher $(\mathrm{P}<0.05)$ when corn stubble was applied $(89.9 \%)$, compared to when it was not applied (81.2\%) (Table 1). By not applying the vegetation cover, the percentage of survival of forest species is significantly reduced, up to $66.7 \%$ [42]. The application of stubble as vegetable cover in crops, improves soil moisture retention by reducing evaporation, in addition to creating a microclimate suitable for germination of the seed, survival and development of the crop in its initial phase [43].

\subsubsection{Air dry matter and plant radical content}

The stubble effect was related to a higher soil moisture content and more evenly distributed, which allowed a higher yield $(\mathrm{P} \leq 0.05)$ of biomass in both grasses. The stubble dose was associated with yield higher than $24.9 \%$ in the native grass and $25.6 \%$ in the introduced

\begin{tabular}{l|l}
\hline $\begin{array}{l}\text { Grass specie/Dose of } \\
\text { retainer of soil water }\end{array}$ & Percent of survival \\
\hline BC & $87.03 \mathrm{a} \pm 1.3$ \\
CG & $84.12 \mathrm{~b} \pm 1.1$ \\
\hline Hydrogel doses & $72.93 \mathrm{~b} \pm 0.9$ \\
$0 \mathrm{~kg} \mathrm{ha}^{-1}$ & $76.42 \mathrm{~b} \pm 1.5$ \\
$10 \mathrm{~kg} \mathrm{ha}^{-1}$ & $88.64 \mathrm{a} \pm 1.2$ \\
\hline $0 \mathrm{~kg} \mathrm{ha}^{-1}$ & \\
\hline tubble coverage & $81.21 \mathrm{~b} \pm 1.4$ \\
$0 \mathrm{t} \mathrm{ha}^{-1}$ & $89.94 \mathrm{a} \pm 1.6$ \\
$10 \mathrm{t} \mathrm{ha}^{-1}$ & \\
\hline
\end{tabular}

$\mathrm{BC}=$ B. curtipendula [Michx.] Torr.; $\mathrm{CG}=$ C. gayana Kunth. ab-Numbers of different letter into each variation factor (grasses, hydrogel and corn stubble) are statistically different $(\mathrm{P}<0.05)$.

Table 1. Percent survival of grasses due to hydrogel and stubble. 
grass, compared to the control (Table 2). In contrast, statistically significant differences $(\mathrm{P} \leq 0.05)$ was obtained for $30 \mathrm{DDR}$ for aerial biomass production using 10 and $20 \mathrm{~kg} \mathrm{ha}^{-1}$ hydrogel. However, in the two subsequent evaluations, the differences in the DDR of the aerial biomass was negligible might due to the dilution effect identified in the moisture content in the soil. To add of stubble significantly increased $(P \leq 0.05)$ the root biomass, obtaining the highest weight at the end of the vegetative cycle in native and introduced grasses. The average increase in biomass of the root in the stubble dose was $43.1 \%$ in native and $38.3 \%$ in the introduced one, with respect to not applying the vegetation cover, in the three evaluations (Table 3).

In this regard, the addition of stubble on the soil surface favorably affects greater biomass production in grasses [44]. Other authors [45] obtained significantly higher increases in forage yield in guinea grass by adding straw to the soil. On the other hand, the hydrogel has shown a more efficient use of water, which improves the growth of plants [46], although this effect was not observed at the time of evaluation.

The amount of rainfall has impact on the effectiveness of the hydrogel applications, as the registered rainfall of $372.2 \mathrm{~mm}$ was $10.0 \mathrm{~mm}$ lower than the annual average in the region (Figure 1A) [47]. The information obtained can be agreed upon the selection of grass species with high potential and soil moisture retention practices, to be used in rehabilitation programs of degraded grassland in arid lands.

\begin{tabular}{|c|c|c|c|c|c|c|}
\hline \multirow[t]{3}{*}{ Dose of retainer of soil water } & \multicolumn{6}{|c|}{ Dry weight of aerial plant biomass (g) } \\
\hline & \multicolumn{2}{|c|}{$30 \mathrm{DDR}$} & \multicolumn{2}{|c|}{45 DDR } & \multicolumn{2}{|c|}{60 DDR } \\
\hline & BC & CG & BC & CG & BC & CG \\
\hline \multicolumn{7}{|l|}{ Hydrogel doses } \\
\hline \multirow[t]{2}{*}{$0 \mathrm{~kg} \mathrm{ha}^{-1}$} & $11.0 \mathrm{~b}$ & $17.5 \mathrm{~b}$ & $45.1 \mathrm{a}$ & $57.9 \mathrm{a}$ & $53.3 \mathrm{a}$ & $68.0 \mathrm{a}$ \\
\hline & \pm 1.7 & \pm 3.3 & \pm 6.0 & \pm 5.5 & \pm 7.1 & \pm 7.0 \\
\hline \multirow[t]{2}{*}{$10 \mathrm{~kg} \mathrm{ha}^{-1}$} & $13.3 \mathrm{ab}$ & $24.3 \mathrm{a}$ & $42.8 \mathrm{a}$ & $56.0 \mathrm{a}$ & $51.5 \mathrm{a}$ & $66.8 \mathrm{a}$ \\
\hline & \pm 2.2 & \pm 4.1 & \pm 5.9 & \pm 5.8 & \pm 6.3 & \pm 7.6 \\
\hline \multirow[t]{2}{*}{$20 \mathrm{~kg} \mathrm{ha}^{-1}$} & $14.7 \mathrm{a}$ & $25.6 \mathrm{a}$ & $44.7 \mathrm{a}$ & $56.9 \mathrm{a}$ & $51.6 \mathrm{a}$ & $67.7 \mathrm{a}$ \\
\hline & \pm 2.0 & \pm 4.9 & \pm 5.3 & \pm 4.2 & \pm 6.2 & \pm 5.8 \\
\hline \multicolumn{7}{|l|}{ Stubble coverage } \\
\hline \multirow[t]{2}{*}{0 tha $^{-1}$} & $12.3 \mathrm{~b}$ & $20.4 \mathrm{~b}$ & $39.8 b$ & $52.3 b$ & $47.2 \mathrm{~b}$ & $61.1 b$ \\
\hline & \pm 2.1 & \pm 1.6 & \pm 3.3 & \pm 2.7 & \pm 4.4 & \pm 2.8 \\
\hline \multirow[t]{2}{*}{$10 \mathrm{t} \mathrm{ha}^{-1}$} & $16.1 \mathrm{a}$ & $28.6 a$ & $48.8 \mathrm{a}$ & $61.1 \mathrm{a}$ & $57.2 \mathrm{a}$ & $73.2 \mathrm{a}$ \\
\hline & \pm 0.9 & \pm 1.9 & \pm 3.9 & \pm 2.8 & \pm 4.5 & \pm 3.2 \\
\hline
\end{tabular}

$\mathrm{BC}=$ B. curtipendula [Michx.] Torr.; $\mathrm{CG}=$ C. gayana Kunth DDR = Days after the first runoff. ab-Numbers of different letter into the same column, and into each variation factor (hydrogel and corn stubble) are statistically different $(\mathrm{P}<0.05)$.

Table 2. Effect of hydrogel and corn stubble on shoot dry biomass of two grass species. 


\begin{tabular}{|c|c|c|c|c|c|c|}
\hline \multirow[t]{3}{*}{ Dose of retainer of soil water } & \multicolumn{6}{|c|}{ Dry weight of shoot dry biomass (g) } \\
\hline & \multicolumn{2}{|c|}{30 DDR } & \multicolumn{2}{|c|}{45 DDR } & \multicolumn{2}{|c|}{60 DDR } \\
\hline & BC & CG & $\mathrm{BC}$ & CG & BC & CG \\
\hline \multicolumn{7}{|l|}{ Hydrogel doses } \\
\hline \multirow[t]{2}{*}{$0 \mathrm{~kg} \mathrm{ha}^{-1}$} & $5.0 \mathrm{~b}$ & $9.1 b$ & $19.5 a$ & $24.3 \mathrm{a}$ & $22.9 a$ & $29.0 \mathrm{a}$ \\
\hline & \pm 0.5 & \pm 1.2 & \pm 4.8 & \pm 4.3 & \pm 4.5 & \pm 4.3 \\
\hline \multirow[t]{2}{*}{$10 \mathrm{~kg} \mathrm{ha}^{-1}$} & $6.6 a$ & $11.7 \mathrm{a}$ & $17.7 \mathrm{a}$ & $24.6 \mathrm{a}$ & $21.7 \mathrm{a}$ & $29.5 a$ \\
\hline & \pm 1.0 & \pm 2.2 & \pm 3.3 & \pm 3.7 & \pm 3.2 & \pm 4.1 \\
\hline \multirow[t]{2}{*}{$20 \mathrm{~kg} \mathrm{ha}^{-1}$} & $6.3 \mathrm{a}$ & $11.9 a$ & $19.0 \mathrm{a}$ & $25.5 a$ & $22.5 a$ & $28.9 \mathrm{a}$ \\
\hline & \pm 0.8 & \pm 2.1 & \pm 3.5 & \pm 3.7 & \pm 3.6 & \pm 3.6 \\
\hline \multicolumn{7}{|l|}{ Stubble coverage } \\
\hline \multirow[t]{2}{*}{$0 \mathrm{tha}^{-1}$} & $4.7 \mathrm{~b}$ & $9.2 b$ & $15.5 b$ & $20.9 b$ & $19.4 b$ & $25.3 \mathrm{~b}$ \\
\hline & \pm 1.8 & \pm 1.1 & \pm 2.4 & \pm 1.5 & \pm 1.9 & \pm 1.3 \\
\hline \multirow[t]{2}{*}{$10 \mathrm{t} \mathrm{ha}^{-1}$} & $7.3 \mathrm{a}$ & $13.9 a$ & $22.1 \mathrm{a}$ & $28.2 \mathrm{a}$ & $25.5 a$ & $32.6 a$ \\
\hline & \pm 0.6 & \pm 1.4 & \pm 2.2 & \pm 1.2 & \pm 2.3 & \pm 1.6 \\
\hline
\end{tabular}

$\mathrm{BC}=$ B. curtipendula [Michx.] Torr.; $\mathrm{CG}=$ C. gayana Kunth DDR = Days after the first runoff. ab-Numbers of different letter into the same column, and into each variation factor (hydrogel and corn stubble) are statistically different $(\mathrm{P}<0.05)$.

Table 3. Effect of hydrogel and corn stubble on root dry biomass of two grass species.

\subsection{Grasslands in the Nazas-Aguanaval middle watershed: case study Mapimí, Dgo}

This study was carried out in Mapimí, Durango, Mexico in 2016. The objective of this study was to evaluate different soil moisture retention practices in the establishment, development and production of grassland in degraded areas of arid lands of northern Mexico. In this case, the use of different soil moisture retention practices and hydrogel and stubbles on the survival and growth of native and introduced grasses (Bouteloua gracilis H.B.K [Lag.] and Pennisetum ciliaris L.) were investigated [48].

\subsubsection{Percentage of establishment and yield of dry matter}

The percent establishment of grasses was equal to or greater than $70 \%$ regardless of species or treatment. Both blue grama and the buffel grasses had a high survival rate, 5 weeks after transplanting in July 2016 (Figure 2). This elevated response was due to the high moisture content of the soil during germination of the grass, which exceeded $26 \%$ of moisture content.

However, in treatments with stubble application, the moisture content levels was higher $(\mathrm{P} \leq 0.01)$ than the rest, with records of $25.8 \%$ on the average (Figure 3 ). The stubble application favored the growth and productivity of the grass. By increasing on the average the soil moisture content by $5.4 \%$, the amount of dry matter is raised by $73 \%$ without the application 

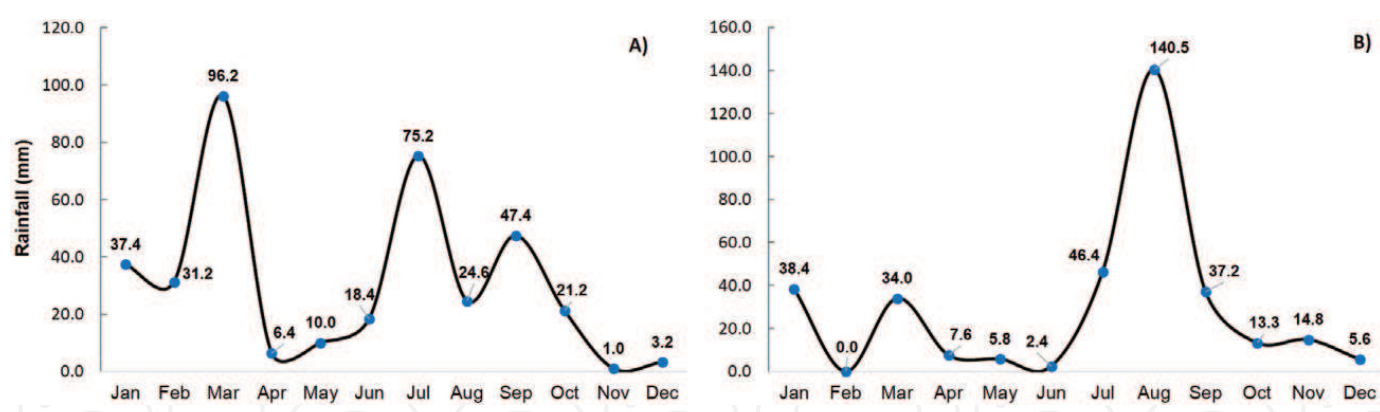

Figure 1. Rainfall during 2015 in the area near to the experimental area to San Luis del Cordero, Dgo, México (A) and rainfall during 2016 in the area near to the experimental area to Mapimí Dgo, México (B).

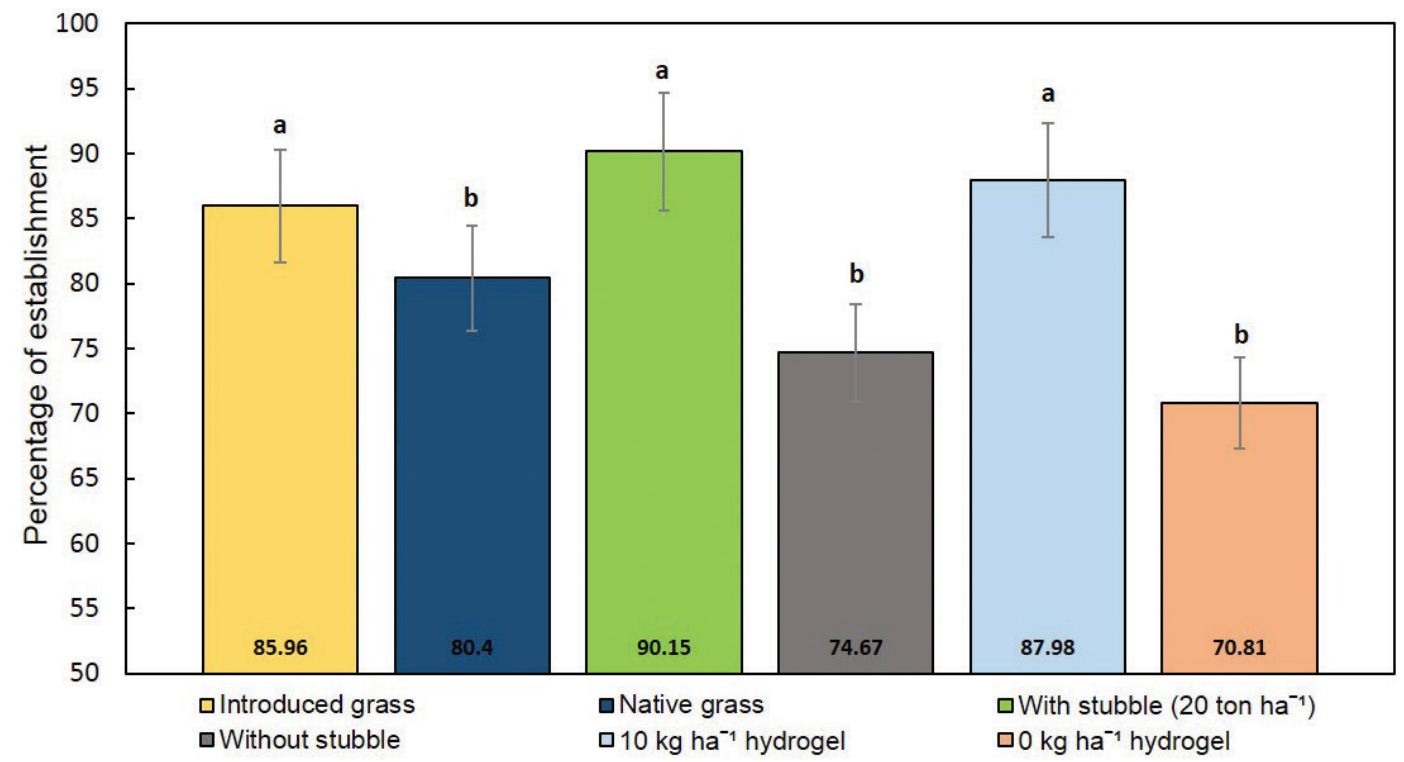

Figure 2. Percent survival by grasses with different types of treatments including stubble and hydrogel. Means with different letters are significantly different from each other $(\mathrm{P}<0.05)$.

of stubble. The use of hydrogel has significantly improved of the rate of germination, but not influenced the amount of grass produced. Likewise, the introduced grass recorded a higher yield, about $75.3 \%$ above the native grass; however, the yields of both grasses were above the average reported for the region [49] (Figure 4).

With the incorporation of mulch to the soil for establishment of grasses it is possible to obtain significantly higher results in relation to treatments without the addition of straw, having a greater amount of vegetation of grasses and biomass [44]; also, improves soil moisture retention by reducing evaporation [43]. Equally, addition of vegetative mulches to have a positive impact on the yield and profitability of the plants, which could largely be attributed to the mulches modifying soil temperature and moisture and in controlling weeds [50]; moreover, the cover crops and living mulches bring many benefits to crop production and plants, such as soil erosion control, reduce weed pressure, increase soil organic matter content, improved soil structure and water infiltration, decreased water runoff, reduced surface soil temperature and water evaporation [51]. 


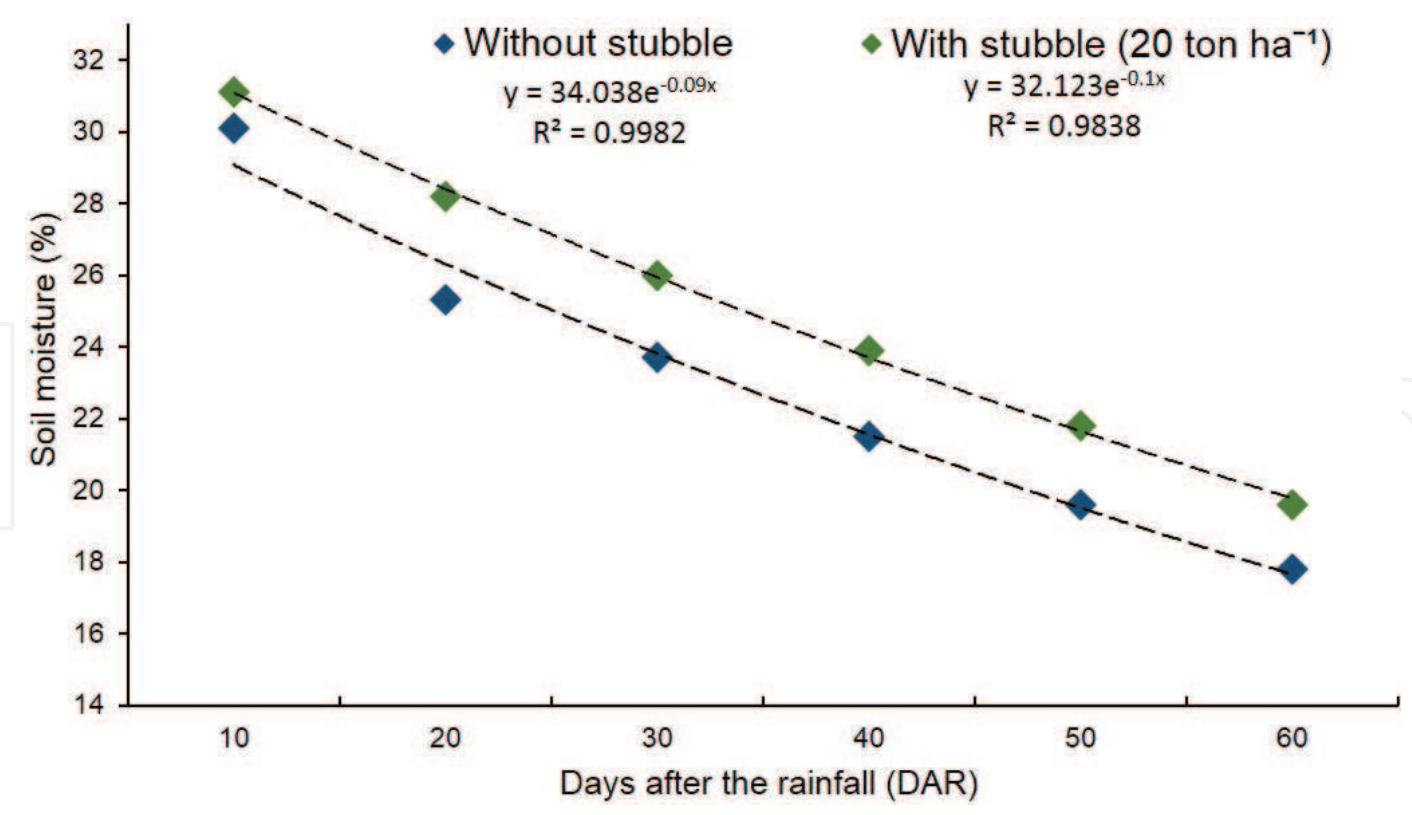

Figure 3. Effect of mulching on soil moisture content at selected dates after treatment application. Means with different letters are significantly different from each other $(\mathrm{P}<0.05)$.

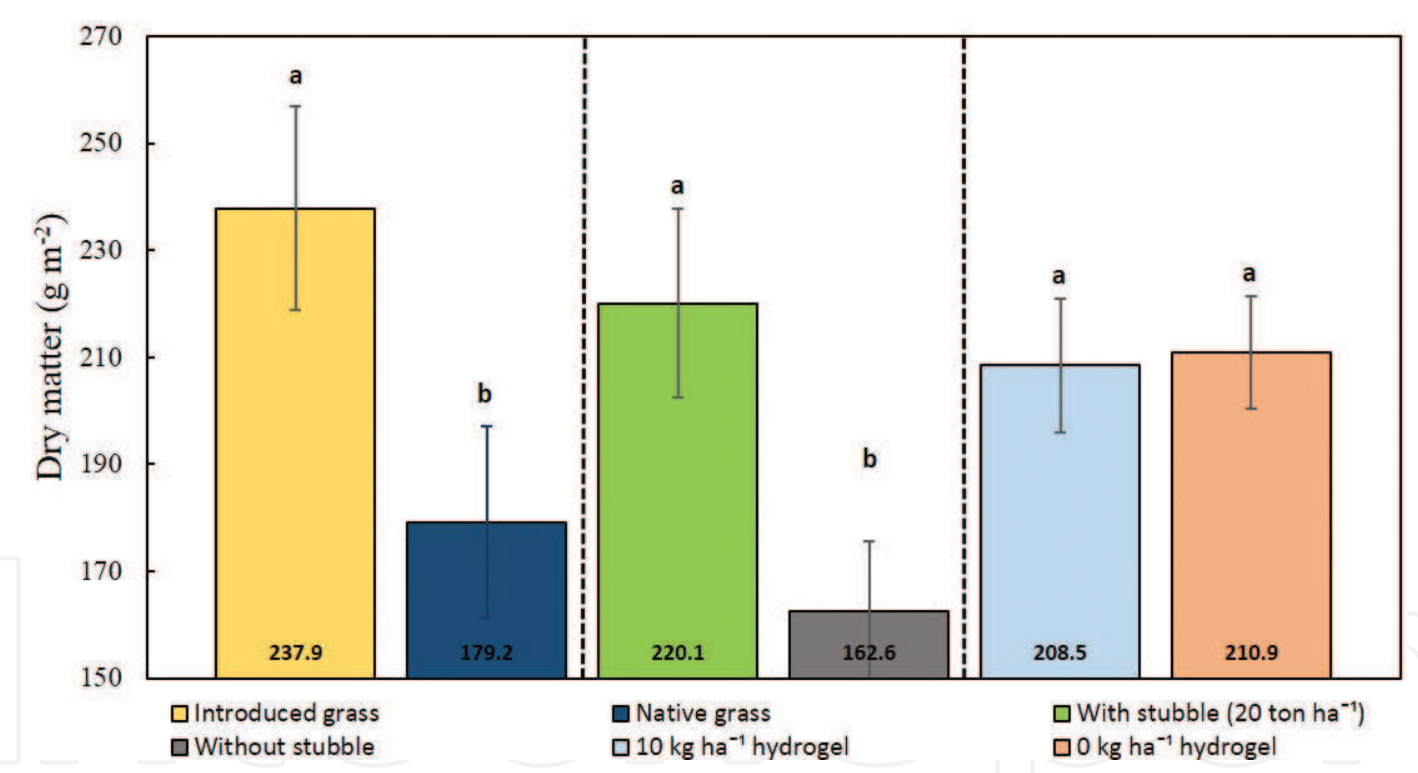

Figure 4. Effect of grasses and soil treatments dry matter yield. Means with different letters are significantly different from each other $(\mathrm{P}<0.05)$.

The yields obtained were mainly benefited by the high rainfall recorded in the area, which was $346.0 \mathrm{~mm}$, about $96 \mathrm{~mm}$ above the annual average in the area (Figure 1B) [47]. The direct sowing of grass seeds and the application of stubble is suggest as the technique increases the percentage of establishment and survival of the grasses. $P$. ciliaris has better advantage over B. gracilis at initial phenological phases by undergoing higher survival rate and producing higher yield. The results of the current study suggests the option of improving grassland 


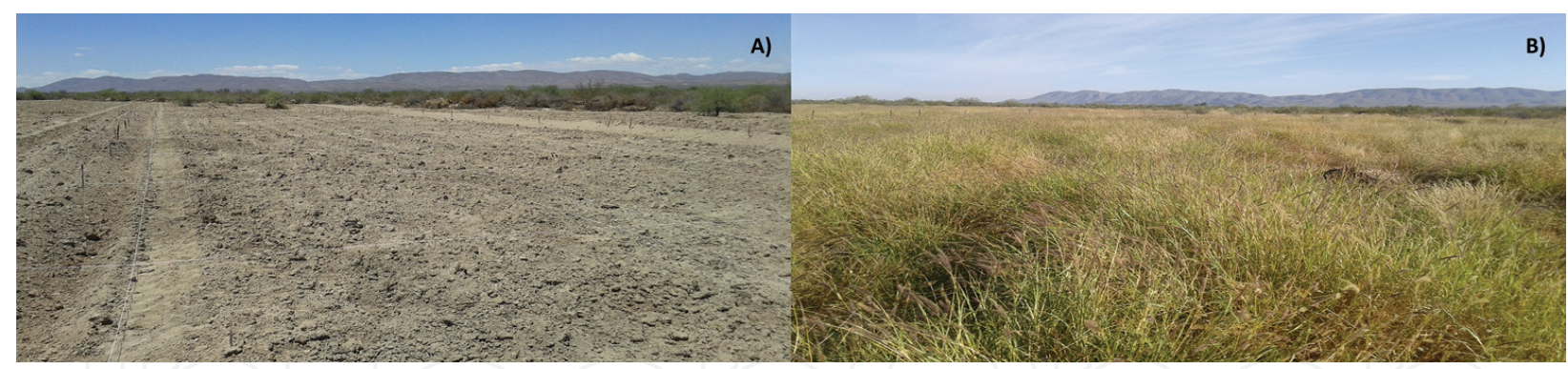

Figure 5. Degraded area with high percentage of bare soil and dominance of undesirable grasses species (A) and establishment of grassland and moisture retention practices with stubbles and hydrogel 1 year later in Mapimí, Dgo (B).

areas using technical and management options to mitigate the impact of drought, restore degraded areas and carry out productive reconversion for grassland in arid and semiarid zones (Figure 5).

\section{Conclusions}

The degradation of grasses is a phenomenon that gets worse every day and is caused by several factors. The management of the grassland plays a key role to reducing the ecological degradation process. Hence, studying and understanding the process of degradation of grassland, as well as their economic and social impact, is considered necessary to develop comprehensive strategies for their recovery.

Facing the challenge of recovering degraded grassland is now an urgent need. There are also no doubts for scientists, producers and government officials that the degradation of the grassland is the prelude to desertification. This last problem, due to its dependence on human and environmental factors, is complex. Hence, any alternative to avoid or diminish its effects on man justifies the attention and effort, for which it is necessary to establish scientific strategies where the costs of grassland recovery are reduced and public policies of credits and services that stimulate the producers to prioritize this specific activity.

Finally, it is necessary to mention that man is the fundamental factor for the recovery of the grassland ecosystem and improve its efficiency, provided that it has sufficient experience or, acquire the necessary knowledge and skills in the priority issues for the application of exploitation technologies, these appropriate to the existing climatic and socioeconomic conditions.

\section{Acknowledgements}

We want to thank to Chapingo Autonomous University for financial support to carry out the research related to the topic soil and water management practices in the productivity of grasses areas in arid zones, as well as to the National Institute of Agricultural Livestock and Forestry Research for their collaboration scientific and technical in this project. 


\section{Author details}

Luis G. Yáñez-Chávez ${ }^{1}$, Aurelio Pedroza-Sandoval2*, Ignacio Sánchez-Cohen³,

Miguel A. Velásquez-Valle ${ }^{4}$ and Ricardo Trejo-Calzada ${ }^{2}$

*Address all correspondence to: apedroza@chapingo.uruza.edu.mx

1 PhD Student of Chapingo Autonomous University Bermejillo, Durango, México

2 Chapingo Autonomous University, Bermejillo, Durango, México

3 National Institute of Agricultural Livestock and Forestry Research, Gómez Palacio, Durango, México

3 National Institute of Agricultural Livestock and Forestry Research, Saltillo, Coahuila, México

\section{References}

[1] Steinfeld H, Gerber P, Wassenaar T, Castel V, Rosales M, Haan C. La larga sombra del ganado: problemas ambientales y opciones. Vol. 464. FAO [Internet]. 2009. Available from: http://www.fao.org/3/a-a0701s.pdf [Accessed: 10 April 2018]

[2] Ilea RC. Intensive livestock farming: Global trends, increased environmental concerns, and ethical solutions. Journal of Agricultural and Environmental Ethics. 2009;22(2): 153-167. DOI: 10.1007/s10806-008-9136-3

[3] Steinfeld H, Wassenaar T, Jutzi S. Livestock production systems in developing countries: Status, drivers, trends. Revue Scientifique et Technique. 2006;25(2):505-516

[4] Wharton J. Subsistence Agriculture and Economic Development. Routledge; 2008. p. 494. [Internet] Available from: https://www.taylorfrancis.com/books/9781351487696 [Accessed: 30 March 2018]

[5] Bilotta GS, Brazier RE, Haygart PM. The impacts of grazing animals on the quality of soils, vegetation, and surface waters in intensively managed grasslands. Advances in Agronomy. 2007;94:237-280. DOI: 10.1016/S0065-2113(06)94006-1

[6] Batey T. Soil compaction and soil management-A review. Soil Use and Management. 2009;25(4):335-345. DOI: 10.1111/j.1475-2743.2009.00236.x

[7] Greenwood KL, Mc Kenzie M. Grazing effects on soil physical properties and the consequences for grassland: A review. Australian Journal of Experimental Agriculture. 2001;41:1231-1250. DOI: 10.1071/EA00102

[8] Asner GP, Elmore AJ, Olander LP, Martin RE, Harris AT. Grazing systems, ecosystem responses, and global change. Annual Review of Environment and Resources. 2004; 29:261-299. DOI: 10.1146/annurev.energy.29.062403.102142

[9] Granados SD, Hernández GMA, Vázquez AA, Ruíz PP. Los procesos de desertificación y las regiones áridas. Revista Chapingo Serie ciencias forestales y del ambiente. 2013;19(1):45-66. DOI: 10.5154/r.rchscfa.2011.10.077 
[10] Estell RE, Havstad KM, Cibils AF, Fredrickson EL, Anderson DM, Schrader TS, James DK. Increasing shrub use by livestock in a world with less grass. Rangeland Ecology \& Management. 2012;65(6):553-562. DOI: 10.2111/REM-D-11-00124.1

[11] Aguirre C, Hoth J, Lafón A. Estrategia para la conservación de los pastizales del desierto Chihuahuense. ECOPAD; 2007. p. 23. [Internet] Available from: http://bva.colech. edu.mx/xmlui/bitstream/handle/123456789/HASH01bdd0a3e68cf84652938337/bio094. pdf?sequence=3 [Accessed: 05 April 2018]

[12] Colomer MJC, Sánchez JD. Agricultura y procesos de degradación del suelo. In: SantaOlalla FM, editor. Agricultura y desertificación. Mundi-Prensa; 2000. pp. 109-131

[13] Contreras AMC, Coirini RO, Zapata RM, Karlin MS. Recuperación vegetal en ambientes áridos: uso de cerramientos en ecosistemas degradados de la Cuenca Salinas Grandes, Argentina. Revista Chapingo Serie Zonas Áridas. 2013;12(2):63-76. DOI: 10.5154/r.rchsza. 2012.05.005

[14] Barrera BN. Los orígenes de la ganadería en México. Ciencias. 1996;44:14-27

[15] Menoca SE, Álvarez AM. Los efectos de la sequía en la ganadería bovina de carne en el sur de Durango, México: hacia una interpretación integral. In: Hernández L, editor. Historia ambiental de la Ganadería en México. Instituto de Ecología; 2001. pp. 241-250

[16] FAO. El estado mundial de la agricultura y la alimentación. In: Organización de la Naciones Unidas para la Agricultura y la Alimentación. FAO; 2009. p. 184. [Internet] Available from: http://www.fao.org/docrep/012/i0680s/i0680s.pdf [Accessed: 02 April 2018]

[17] Calypso SA, editor. COTECOCA, Secretaría de Agricultura y Recursos Hidráulicos, Subsecretaria de Ganadería Durango, Comisión Técnico Consultiva para la Determinación Regional de los Coeficientes de Agostadero; 1979. 200 p

[18] Echavarría CFG, Medina GG, Rumayor RAF, Serna PA, Salinas GH, Bustamente WJG. Diagnóstico de los recursos naturales para la planeación de la intervención tecnológica y el ordenamiento ecológico. INIFAP; 2009. DOI: 10.13140/2.1.3453.0084

[19] Wassenaar T, Gerber P, Verburg PH, Rosales M, Ibrahim M, Steinfeld H. Projecting land use changes in the Neotropics: The geography of pasture expansion into forest. Global Environmental Change. 2006;17(1):86-104. DOI: 10.1016/j.gloenvcha.2006.03.007

[20] Velázquez VMA, Alba AA, Gutiérrez LR, García EG. Prácticas de restauración de suelos para la conservación del agua. Folleto Técnico No. 46. INIFAP; 2012. p. 97

[21] PNUMA. Land Degradation in Drylands (LADA): GEF Grant Request. Nairobi: Programa de las Naciones Unidas para el Medio Ambiente; 2004. p. 29

[22] Millennium Ecosystem Assessment, (MEA). In: Ecosystems and Human Well-Being: Desertification Synthesis. Vol. 26. World Resources Institute [Internet]. 2005. Available from: https://www.millenniumassessment.org/documents/document.356.aspx.pdf [Accessed: 11 March 2018]

[23] Reid R, Thornton P, Mccrabb G, Kruska R, Atieno F, Jones P. Is it possible to mitigate greenhouse gas emissions in pastoral ecosystems of the tropics? Environment, Development and Sustainability. 2004;6:91-109. DOI: 10.1023/B:ENVI.0000003631.43271.6b 
[24] Segrelles SJA. Problemas ambientales, agricultura y globalización en América Latina. Scripta Nova. Revista Electrónica de Geografía y Ciencias Sociales. 2001;5(92):32

[25] Calle Z, Murgueitio E, Chará JJ. Integración de las actividades forestales con la ganadería extensiva sostenible y la restauración del paisaje. Unasylva. 2012;63(239):31-40

[26] Stavi I, Lal R. Achieving zero net land degradation: Challenges and opportunities. Journal of Arid Environments. 2015;112:44-51. DOI: 10.1016/j.jaridenv.2014.01.016

[27] UNCCD. Zero Net Land Degradation. In: A Sustainable Development Goal for Rio+20 to Secure the Contribution of our planet's Land and Soil to Sustainable Development, Including Food Security and Poverty Eradication. 2nd ed. Ediouro Grafica e Editora; 2012. p. 28. [Internet] Available from: https://www.commonland.com/en/file/download/126 [Accessed: 26 February 2018]

[28] López BW. Análisis del manejo de cuencas como herramienta para el aprovechamiento sustentable de recursos naturales. Revista Chapingo Serie Zonas Áridas. 2014;13(2): 39-45. DOI: 10.5154/r.rchsza.2012.06.017

[29] Holechek JL, Pieper RD, Herbel CH. Range Management: Principles and Practices. 6th ed. Vol. 444. Prentice-Hall/Pearson, Inc; 2011

[30] Echavarría CFG, Pérez E, Aguirre AS, Rodríguez FAR, González HS. Productividad del chamizo Atriplex canescens con fines de reconversión: dos casos de estudio. Técnica pecuaria en México. 2009;47(1):93-106

[31] Lored OC, editor. Prácticas para la conservación del suelo y agua en zonas áridas y semiáridas. INIFAP; 2005. $187 \mathrm{p}$

[32] Pellant M, Shaver P, Pyke DA, Herrick JE. Interpreting Indicators of Rangeland Health, Version 4. Technical Reference 1734-6. U.S. Department of the Interior, Bureau of Land Management, National Science and Technology Center; 2005. p. 122. [Internet] Available from: https://www.blm.gov/nstc/library/pdf/1734-6rev05.pdf [Accessed: 10 April 2018]

[33] Martín GO. Técnicas de refinamiento y recuperación de pastizales. 1a ed. San Miguel de Tucumán: Universidad Nacional de Tucumán; 2014. p. 65

[34] Cruz MA, Pedroza SA, Trejo CR, Sánchez CI, Samaniego GJA, Hernández SR. Captación de agua de lluvia y retención de humedad edáfica en el establecimiento de buffel (Cenchrus ciliaris L). Revista Mexicana de Ciencias Pecuarias. 2016;7(2):159-172. DOI: 10.22319/rmcp.v7i2.4171

[35] Yáñez CLG, Pedroza SA, Martínez SM, Sánchez CI, Echavarría CJG, Velásquez VMA, López SA. Retención de humedad edáfica en la sobrevivencia y crecimiento de dos especies de pastos Bouteloua curtipendula [Michx.] Torr. y Chloris gayana Kunth en Durango, México. Revista Mexicana de Ciencias Pecuarias. 2018. [in progress]

[36] Chávez RE, González CG, González BJL, López DA. Retos de la investigación del agua en México. In: Oswald SU, editor. La evapotranspiración en la cuenca baja y media del río Nazas. UNAM; 2011. p. 754. [Internet] Available from: https://agua.org.mx/wp-content/ 
uploads/2017/06/retos-de-la-investigaci\%C3\%B3n-del-agua-en-mexico.pdf [Accessed: 06 April 2018]

[37] Barón CA, Barrera RIX, Boada ELF, Rodríguez NG. Evaluación de hidrogeles para aplicaciones agroforestales. Revista Ingeniería e Investigación. 2007;27(3):35-44

[38] Narjary B, Aggarwal P, Singh A, Chakraborty D, Singh R. Water availability in different soils in relation to hydrogel application. Geoderma. 2012;187-188:94-101. DOI: 10.1016/j. geoderma.2012.03.002

[39] Obalum SE, Igwe CA, Eze OM. Soil moisture dynamics under rainfed sorghum and soybean on contrasting tillage-mulch seedbeds in a mineral sandy loam at derived savanna of South-Eastern Nigeria. Archives of Agronomy and Soil Science. 2012;58(11): 1205-1227. DOI: 10.1080/03650340.2011.575065

[40] Taparauskienė L, Miseckaitė O. Effect of mulch on soil moisture depletion and strawberry yield in sub-humid area. Polish Journal of Environmental Studies. 2014;23(2):475-482

[41] González DJR, Gómez MS, López DA. El trasplante garantiza establecer zacates forrajeros en suelos salinos y arcillosos. Memorias del VI Congreso Internacional de Manejo de Pastizales. Durango. Dgo. 2015:464

[42] Nissen J, Ovando C. Efecto de un hidrogel humectado aplicado a las raices de Nothofagus obliqua (MIRB.) OERST. y Nothofagm dombeyi (MIRB.) OERST. durante su trasplante. Agro sur. 1999;27(2):48-58

[43] Julca OA, Meneses FL, Blas SR, Bello AS. La materia orgánica, importancia y experiencia de su uso en la agricultura. Idesia (Arica). 2006;24(1):49-61. DOI: 10.4067/S071834292006000100009

[44] Beggy HM, Fehmi JS. Effect of surface roughness and mulch on semi-arid revegetation success, soil chemistry and soil movement. Catena. 2016;143:15-220. DOI: 10.1016/j. catena.2016.04.011

[45] Kusmiyati F, Sumarsono S, Karno K, Pangestu E. Effect of mulch and mixed cropping grass-legume at saline soil on growth, forage yield and nutritional quality of Guinea grass. Journal of the Indonesian Tropical Animal Agriculture. 2013;38(1):72-78. DOI: 10.14710/jitaa.38.1.72-78

[46] El-Hady OA, Safia MA, Abdel KAA. Sand-compost- hydrogel mix for low cost production of tomato seedlings. Egyptian Journal of Soil Science. 2002;42:767-782

[47] INIFAP. Red de Estaciones Agroclimáticas. Secretaría de Agricultura Ganadería y Pesca [Internet]. 2018. Available from: http://clima.inifap.gob.mx/lnmysr [Accessed:April 12, 2018]

[48] Yáñez CLG, Pedroza SA, Martínez SM, Sánchez CI, Echavarría CJG, Velásquez VMA, López SA. Retención de humedad del suelo e impacto en el crecimiento y desarrollo de dos pastos (Bouteloua gracilis H.B.K [Lag.] y Pennisetum ciliaris L.) en suelos degradados de zonas áridas. In: Memorias III Congreso Internacional y XIII Congreso Nacional Sobre Recursos Bióticos de Zonas Áridas, Bermejillo, Durango. Méx; 2017. pp. 99-100 
[49] Velázquez MM, Hernández GFJ, Cervantes BJF, Gámez VHG. Establecimiento de pastos nativos e introducidos en zonas áridas de México. INIFAP; 2015. p. 22

[50] Manu V, Whitbread A, Blair G. Mulch effect on successive crop yields and soil carbon in Tonga. Soil Use and Management. 2017;33(1):98-105. DOI: 10.1111/sum.12314

[51] Hartwig NL, Ammon HU. Cover crops and living mulches. Weed Science. 2002;50(6): 688-699. DOI: 10.1614/0043-1745(2002)050[0688,AIACCA]2.0.CO;2 


\title{
Chapter 4
}

\section{Grasses in Arid and Semi-Arid Lands: The Multi- Benefits of the Indigenous Grasses}

\author{
Suzan Shahin and Mohammed Salem \\ Additional information is available at the end of the chapter
}

http://dx.doi.org/10.5772/intechopen.79151

\begin{abstract}
Drought regions are the most critical areas of the world. The challenging environmental conditions create severe concerns in arid and semi-arid lands. Consequently, the management task is crucial to face the proposed complicated ecological conditions. The main objective of this chapter is to focus on the vital roles of the indigenous grasses in drought areas and how the same could be a perfect solution in the urban planning of such places sustainably. Examples of the indigenous grasses of arid and semi-arid regions from the Poaceae family will be illustrated along their multi-economic values. In addition, promising innovative approaches required to face the demanding future of the agricultural sector will be presented and discussed.
\end{abstract}

Keywords: arid and semi-arid regions, economic value, global concerns, indigenous grasses, innovative technologies, morphophysiological characteristics, sustainability, water scarcity

\section{Introduction}

Arid and semi-arid lands are regions of the world that have harsh environmental conditions, including high temperatures, high evapotranspiration rates, low precipitation rates, and scarcity of freshwater resources. Consequently, the management task of such regions is a challenging mission, especially with the growing concerns of climate change, population explosion, and food security.

This chapter provides insights into how the indigenous grasses can be a perfect candidate to rescue the future of the agricultural sector in arid and semi-arid regions sustainably, focusing on the major role of grasses in urban planning. In addition, examples of predominant grass 
communities that have multi-economic benefits of add value in arid and semi-arid areas will be discussed. In addition, the chapter offers promising innovative approaches in such drought regions.

\section{Drought regions}

Tropical desert (TBWh) is the global ecological zone (GEZ) that is characterized by severe ecological conditions including high summer temperatures, high evapotranspiration (ET), and low and irregular precipitation [1]. The sandy soil texture is predominant with high porosity, high water permeability, low water holding capacity, poor nutrient content, and thus low fertility [2-6].

Under such conditions certain vegetation can adapt and survive [5-7]. Such flora was for centuries a free resource that provides free ecological services including shelter, food, and medication [5].

\section{Global concerns and the demanding future}

Currently, there are major concerns threatening the future of the agricultural sector in many regions around the world, particularly in arid and semi-arid areas. Concerns are associated with the sharp global population growth, depletion of natural resources (e.g., fresh water), pollution (e.g., air, water, and soil), and climate change and global warming [8, 9]. Since 1960, global population is dramatically increasing, reaching 7.442 billion in 2016 with sharp growth projections [10], which are expected to reach over 9 billion by 2050. More people means more natural resources required to cover the basic life requirements, such as water, food, medication, and accommodation $[8,9]$.

The concerns are more serious in the era of climate change, where regions with scarcity in freshwater resources are subjected to worse drought conditions, associated with extreme ecological events of severe implications on the limited available natural resources and thus on food productivity. Particularly, the same synchronized with the sharp expansion in industrial activities, urbanization, and population. Consequently, it could be highly expected that the drought regions could be much more susceptible and sensitive to any further environmental challenges [2].

The situation is more critical in developing countries, which have limitations on the environmental resources (e.g., water, land, and energy) and thus have high risks of hunger and poverty. Based on the Food and Agriculture Organization of the United Nations (FAO), the global demand for cereals will increase by $70 \%$ in 2050 compared to the current rates and would be doubled in many low-income nations [11]. Also, the demand for food will sharply grow in high-income countries, which have high per capita food consumption rates [12]. 


\section{Indigenous grasses of drought regions}

The indigenous plants including the indigenous grasses can play a significant role in mitigating the demanding future of arid and semi-arid lands. Special attention should be given to the industrial gasses that can bring extra economic value by each water drop to the drought regions $[8,13]$. Such plants can provide maximum benefits with minimal inputs, as illustrated in Figure 1.

There are many desert grasses that have the capability of producing expensive secondary metabolites (e.g., terpenes) as their defense phytochemicals. Such natural compounds have many therapeutic applications in the traditional herbal practices [13].

For example, Cyperus rotundus L. (English name: Coco grass) from Cyperaceae (Sedges family) is a perennial grass that is widespread in sandy and saline soils, like in the central areas of Tunisia, northern parts of the United Arab Emirates, Southern Africa, and Northern India. This grass is not used as a forage grass only, but it is also eaten to treat worm infections and regulate menstruation. Its seeds are heated with oil and used as ear drops to soften earwax. Besides, this grass is an ingredient in tooth powder to whiten teeth. Moreover, C. rotundus is used by Greek as a diuretic, to break up stones, and to treat uterine disorders. The herbal extract of $C$. rotundus

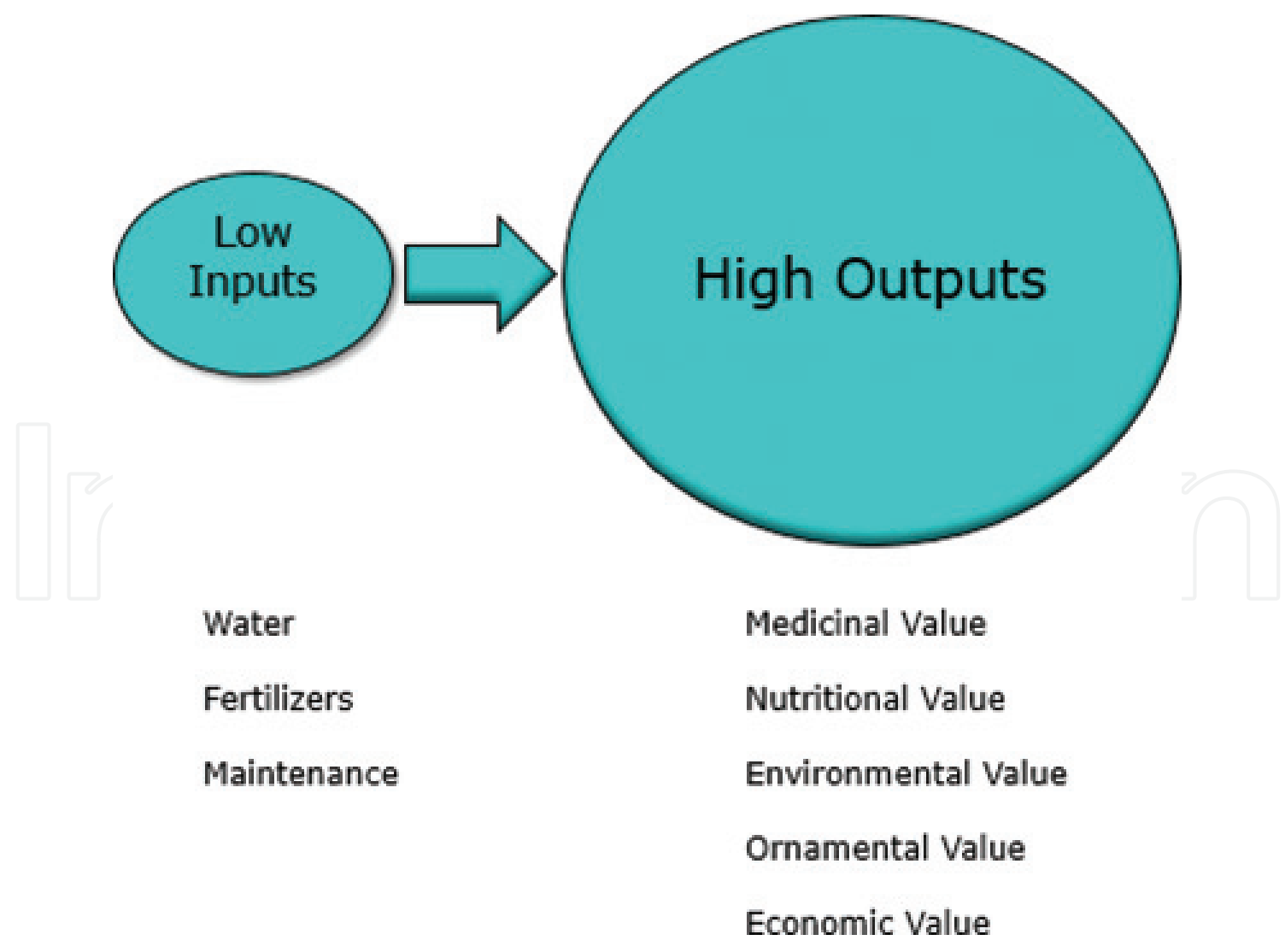

Figure 1. The Add value of the indigenous grasses in the drought regions. 
rhizomes is found to be rich in sesquiterpenes and monoterpenes and proven to be a rich source of antioxidants and antibacterial bioactive compounds [14, 15].

Besides the healing benefits, there are many grass species that have excellent landscaping and urbanization potentials. The same is due to their unique shapes, textures, and colors which is totally opposite of the general concept of the desert plants by the public community. For example, Cyperus arenarius Retz. (English name: Dwarf sedge), which is a perennial grass of the Cyperaceae family, has high value as a landscaping grass in the urbanization activities of sandy and coastal saline habitats [16, 17].

Consequently, while the indigenous grasses of the arid and semi-arid regions can be cultivated to provide various therapeutic, nutraceutical, and health-care applications, they also could be employed to sustain the landscaping beauty and to conserve a balanced ecosystem. Examples of potential grasses from the Poaceae family are provided in Table 1.

On the other hand, cultivating exotic grasses, which are originally from other regions (e.g., temperate region), requires enormous amounts of inputs (e.g., water and soil nutrients) to survive and grow [32]. Even with the application of the modern irrigation technologies, which save $60 \%$ of the watering amounts [11], most of these grasses have high watering requirements, lack adaptation mechanisms, and disturb the natural balance of the desert ecosystem. In additional, to the high irrigation requirements, exotic grasses are labor intensive (e.g., adding fertilizers and maintenance) leading to expensive environmental and economic costs. Due to these, the cultivation of exotic grasses is restricted or even banned in some areas [32].

Similarly, some indigenous grasses in the drought regions that consume high amount of water should be cultivated wisely. For example, Rhodes grass (Chloris gayana Knuth.), which is a

\begin{tabular}{|c|c|c|c|c|}
\hline No. & Botanical name (common name) & Characteristics & Economic value & References \\
\hline 1 & Cynodon dactylon L. (Bermudagrass) & Halophyte & Medicinal, landscaping, forage & {$[18-21]$} \\
\hline 2 & Paspalum vaginatum Sw. (Paspalum) & $\begin{array}{l}\text { Halophyte, } \\
\text { xerophyte }\end{array}$ & Landscaping & {$[22,23]$} \\
\hline 3 & Cenchrus ciliaris L. (Buffel grass) & Halophyte, & Medicinal, forage & {$[19,24,25]$} \\
\hline 4 & $\begin{array}{l}\text { Pennisetum setaceum (Forssk.) Chiov. } \\
\text { (Fountain grass) }\end{array}$ & $\begin{array}{l}\text { Halophyte, } \\
\text { xerophyte }\end{array}$ & Landscaping & {$[26,18]$} \\
\hline 5 & Desmostachya bipinnata L. (Halfa grass) & $\begin{array}{l}\text { Halophyte, } \\
\text { xerophyte }\end{array}$ & Medicinal, religious & {$[19,27]$} \\
\hline 6 & $\begin{array}{l}\text { Cymbopogon commutatus (Steud.) Stapf. } \\
\text { (Incense grass) }\end{array}$ & Halophyte & $\begin{array}{l}\text { Medicinal, landscaping, forage, } \\
\text { insecticidal, aromatic }\end{array}$ & [19] \\
\hline 7 & Cymbopogon schoenanthus L. (Camel grass) & Xerophyte & $\begin{array}{l}\text { Medicinal, landscaping, insecticidal, } \\
\text { aromatic }\end{array}$ & {$[28,29]$} \\
\hline 8 & $\begin{array}{l}\text { Cymbopogon jwarancusa (Jones) Schult. (Oil } \\
\text { grass) }\end{array}$ & Halophyte & Medicinal, forage, aromatic & {$[30,31]$} \\
\hline
\end{tabular}

Table 1. Economic value of common perennial grasses of Poaceae family in drought regions. 
perennial grass from the Poaceae family, has high value as a forage grass in warm regions. However, since it is a water-intensive grass, growing it as a forage grass has been banned in many countries (e.g., in United Arab Emirates) [32].

\subsection{Morphophysiological characteristics}

Cultivating the indigenous grasses could greatly mitigate the water scarcity situation with robust adaptation strategies to survive the drought conditions. Over the time, these desert grasses have developed diverse morphophysiological mechanisms to adapt to arid environmental conditions, as illustrated in Table 2 [4, 13]. These environmental conditions include high intensity of sunlight, high wind speed, rapid loss of water through evaporation or evapotranspiration, low amount of precipitation, low soil moisture content, low soil waterholding capacity, high rate of water permeability, high level of soil salinity, and deficiency in soil nutrients $[33,34]$.

Many indigenous grasses of the drought regions belong to the xerophytes and/or halophytes as indicated in Table 1, which are adapted to water scarcity and soil salinity, respectively [33, 34].

In addition, the following morphological properties enable desert plants to adapt to the prevailing harsh environmental condition: seeds dormancy, long root system, light green color, small leaf area, succulent plant parts, presence of hairy surface and thorns, short growth rate, and short life cycle (ephemerals) [33, 34].

Physiological adaptation of grasses in drought regions is another adaptation mechanism that enables the plant either to reduce the amount of water loss, "transpiration," or increase the ability of the grass to uptake more water. The same is achieved by different physiological and biochemical modifications [19].

For example, some grasses have the ability to control stomatal opening during the day, thus controlling transpiration rates and reducing water loss. Also, controlling the osmotic pressure of plant cells in drought and saline habitats is another important physiological adaptation mechanism that reduces the osmotic potential of plant cell solutes to lower levels compared to the water potential of the surrounding environment, which enables the roots to uptake more water and enhances plant water-use efficiency. Proline accumulation is another adaptation mechanism to survive stress factors, like water limitation. The accumulation of such organic compounds inside plant cells helps in reducing the osmotic potential, thus enhancing soilwater uptake. Besides, the capability of plant cell components to have higher rates of water bound plays a major role in reducing water loss during transpiration [19].

Photosynthesis carbon fixation pathways of C4 and CAM plants are vital mechanisms to adapt to hot and arid environments. Such pathways are associated with higher rates of water-use efficiency, thus a better water conservation strategy. Most indigenous grasses from drought regions are following these carbon fixation pathways [19]. Examples of such grasses that are following the C4 pathway are illustrated in Table 1, that include Cynodon dactylon L., Paspalum vaginatum Sw., Cenchrus ciliaris L., Pennisetum setaceum (Forssk.) Chiov, Desmostachya bipinnata L., Cymbopogon schoenanthus L., and Cymbopogon jwarancusa (Jones) Schult. 
No. Botanical name (Common Plant photo and identification

Adaptation characteristics

References name)

1 Cymbopogon commutatus (Steud.) Stapf. (Incense grass)

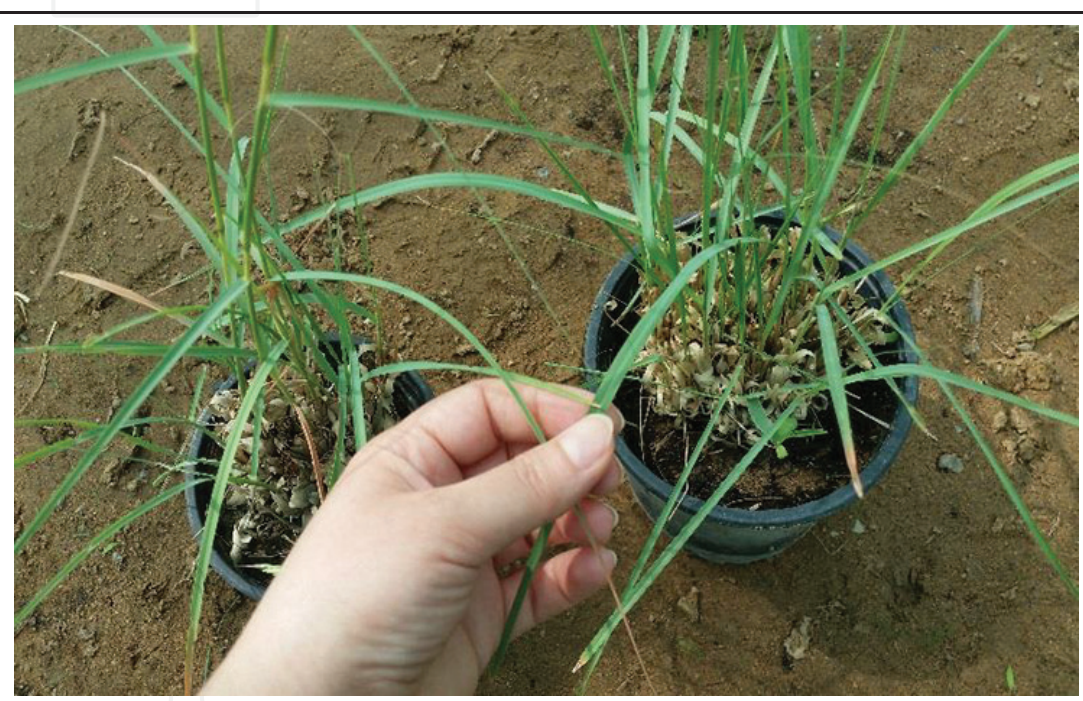

Narrow pointed leaves and hairy basal

[19] sheaths, moderate salt tolerant

Dr. Mohamed Taher Mousa

2 Cenchrus ciliaris L. (Buffel grass)

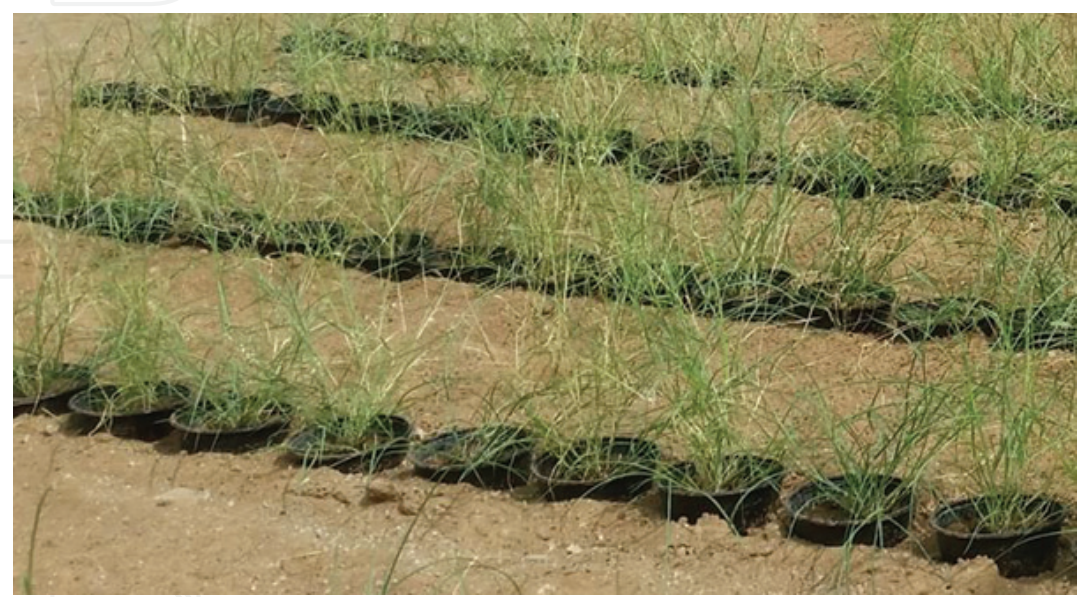

Narrow pointed leaves, C4-plant, highly $\quad[19,24,25]$ salt tolerant, drought tolerant grass

Prof. Ali El-Keblawy 
No. Botanical name (Common Plant photo and identification name)

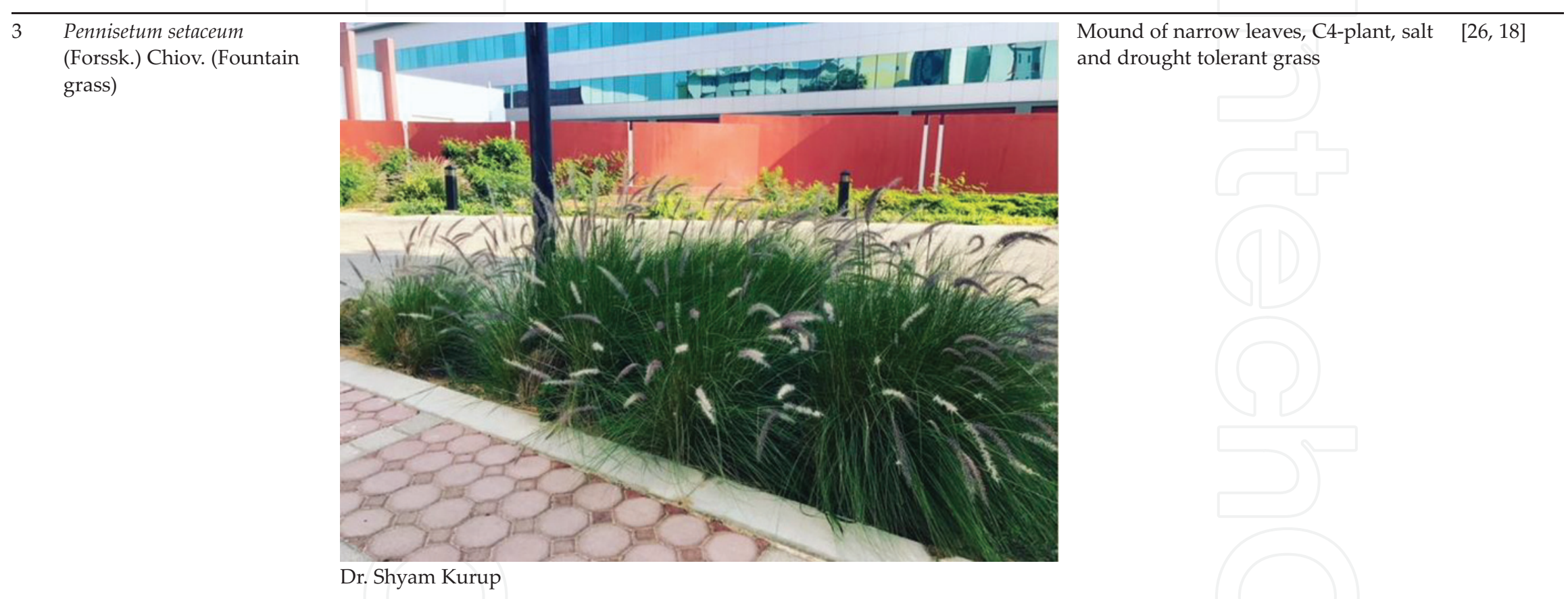

Note: Plant photos are taken by authors of this work.

Table 2. Adaptation characteristics of common perennial grasses from Poaceae family.

References

Pennisetum setaceum
(Forssk.) Chiov. (Fountain

grass)

Mound of narrow leaves, C4-plant, salt $\quad[26,18]$

and drought tolerant grass
Adaptation characteristics 


\subsection{Sustainable value}

Grasses are the most plentiful species in the plant kingdom with enormous socio-economic potentials. Growing the indigenous grasses in drought regions can provide the community with great sustainable values, including the cultural, environmental, and economic values as discussed below:

\subsubsection{Cultural benefits}

There is no doubt that the indigenous grasses provide great cultural and social values for the local community. In the old times, such plants had been greatly used in traditional medicine, as the only available resources for therapeutic and medication purposes, which established a strong relationship between these plants and the Bedouin people who historically inhabited the desert regions $[4,35]$.

For example, Buffel grass (Cenchrus ciliaris L.) has been used in the Zulu traditional herbal practices as a pain reliever and to cure many diseases, such as menstrual disorders, urinary infections, kidney pain, tumors, sores, and wounds [36]. Also, oil grass (Cymbopogon jwarancusa (Jones) Schult.) has been used by Indians to treat blood disorders, vomiting, skin problems, unconsciousness, and abdominal tumors [37].

\subsubsection{Ecological benefits}

Grasses play a major role in the fight against desertification. It is a cost-effective method of soil binding and fixation to mitigate land degradation in dry lands. It is of particular interest in urban planning to cultivate the indigenous grasses of the drought regions, which conserve natural resources and maintain a balanced and healthy ecosystem [38]. For example, dwarf sedge (Cyperus arenarius Retz.) from the Cyperaceae family provides major ecological services in the sandy, saline, and coastal habitats [17].

\subsubsection{Economic benefits}

There are a lot of grass species in drought regions that can offer multi-economic benefits, including food and nutritional resource, medicinal, cosmetic, flavoring, and fragrance. Examples of selected grasses and their benefits are shown in Table 1.

\subsection{Innovative technologies and approaches}

Certainly, the agricultural sector in drought regions has to adopt the best agricultural practices and irrigation methods in cultivating selected indigenous grasses that can best survive the harsh conditions and at the same time provide multi-economic benefits. Such agricultural practices include deficit irrigation and irrigation scheduling, which reduce watering volumes, increase water-use efficiency and thus increase water productivity. Studies need to be done to determine an optimized amount (model) of irrigation schedule, in order to apply the minimum amount of water which returns in maximum possible yield considering the prevailing and expected change in climate $[32,39]$. 
Undoubtedly, it is very important to imitate the natural and original environment of the drought areas, through focusing on planting the indigenous grass species from the xerophytes and halophytes. Besides, the adoption of hardscaping and xeriscaping plays an essential role in reducing the heavy pressure on the limited available water resources $[5,13,32]$.

On the other hand, exotic grasses have to be restricted or even banned since most of these grasses require high amounts of irrigation water and labor for maintenance and fertilization; they thus pose very expensive environmental and economic costs. It is, therefore, recommended to replace these exotic grasses with salt and drought-tolerant species, which substantially reduce water requirements and sustainably maintain a balanced and healthy ecosystem [32].

New approaches are applied to reduce water loss and enhance plant soil-water uptake. One of these approaches is the application of hydrophobic sand, which is originally beach sand coated with chemically treated pure silica. According to Salem et al. [40], mixing the hydrophobic sand with the agricultural soil improves soil and plant characteristics and conserves water use without causing any adverse effects to the cultivated plants. Successful initiatives were reported with Bermudagrass (Cynodon dactylon L.), showing better growth rates, while keeping the plant mineral composition (e.g., $\mathrm{Cd}, \mathrm{Mo}, \mathrm{Pb}$, and $\mathrm{Se}$ ) within acceptable limits [40].

\section{Conclusion}

It is crucially needed to use each drop of expensive freshwater resource in drought regions cautiously and wisely. This could be done through focusing on cultivating the indigenous industrial gasses that can best adapt and mitigate the harsh environmental conditions, and still produce expensive raw materials of great applications (e.g., food and pharmaceuticals), offering potential ecological and/or landscaping services sustainably. Cultivating the indigenous grasses of drought lands should be synchronized with the best agricultural practices and the most recent innovations of soil-plant water use efficiency.

The demanding future of the greenery sector in the arid and semi-arid regions does not rely on how to enlarge the available freshwater resources (which are already limited and scarce), as much as relying on how to best employ such limited resources to gain maximum economic benefits to arid and semi-arid regions sustainably.

\section{Author details}

Suzan Shahin and Mohammed Salem*

*Address all correspondence to: mohammed.s@uaeu.ac.ae

Aridland Agriculture Department, United Arab Emirates University (UAEU), Al Ain, United Arab Emirates (UAE) 


\section{References}

[1] Iremonger S, Gerrand AM. Global Ecological Zones for FAO Forest Reporting, 2010. Rome: FAO; 2011. Unpublished report

[2] Ajaj R, Shahin S, Salem M. The challenges of climate change and food security in the United Arab Emirates (UAE): From deep understanding to quick actions. The Journal of Current Nutrition and Food Science. Bentham Science Publishers. 2018;14:1-8. DOI: $10.2174 / 1573401314666180326163009$

[3] Ajaj R, Shahin S, Kurup S, Cheruth J, Salem M. Elemental fingerprint of agriculture soils of Eastern Region of the Arabian Desert by ICP-OES with GIS mapping. The Journal of Current Environmental Engineering. Bentham Science Publishers. 2018;5(1):1-23. Accepted for Publication. BMS-CEE-2018-1

[4] Shahin SM, Salem MA. Review future concerns on Irrigation requirements of date palm tree in the United Arab Emirates (UAE): Call for quick actions. In: Proceedings of the 5th International Date Palm Conference, Date Palm Improvement Section; Abu Dhabi; 16-18 March, 2014. pp. 255-262. ISBN: 978-9948-22-868-4

[5] Shahin S, Salem M. The challenges of water scarcity and the future of food security in the United Arab Emirates (UAE). Natural Resources and Conservation. 2015;3(1):1-6. DOI: 10.13189/nrc.2015.030101. ISSN: 2331-6365. ISSN: 2331-6373

[6] Simons H, Soto X, Zhu Z, Singh KD, Bellan MF, Iremonger S, Hirvonen H, Smith B, Watson V, Tosi J, Morales L, Shvidenko A, Bohn U, Hettwer C, Barkoudah Y, Du Z, Tickle P. Global Ecological Zoning for the Global Forest Resources Assessment 2000. Final Report. Rome, Italy: Food and Agriculture Organization of the United Nations (FAO); 2001

[7] Shahin S, Kurup S, Cheruth J, Lennartz F, Salem M. Growth, yield, and physiological responses of Cleome amblyocarpa Barr. \& Murb. under varied irrigation levels in sandy soils. Journal of Food, Agriculture and Environment. Publisher: WFL Publisher Ltd. JFAE. 2018;16(2):124-134

[8] Ajaj R, Shahin S, Salem M. The challenges of climate change and food security in the United Arab Emirates (UAE): A critical review of the influence of UV-B radiation with future research perspectives. In: Proceedings of the Third International Conference on Global Warming: Food Security. United Arab Emirates: Publisher RAK Environment Protection and Development Authority; 2015. p. 33

[9] Ajaj R, Salem M. Estimating the potential negative effects of elevated ultraviolet-B (UV-B) radiation on global agricultural sustainability: Status, challenges and recommendations. In: The Annual Meeting of the American Society of Agronomy (ASA). ACSESS Digital Library; 2015

[10] World Bank. Total Population Data. The World Bank Group. Available from: https://data. worldbank.org/indicator/SP.POP.TOTL [Accessed: April 20, 2018] 
[11] Frenken K. FAO (Food and Agriculture Organization of the United Nations). Irrigation in the Middle East Region in Figures (Water Reports 34). Rome, Italy: Food and Agriculture Organization of the United Nations (FAO); 2008

[12] Shahin S, Ajaj R, Salem M. Climate change and food security: Bridging the interaction gaps for future integrity. In: Proceedings of The Transitioning Cereal Systems to Adapt to Climate Change. Minneapolis, USA; 13-14 November, 2015. p. 41

[13] Shahin S, Salem M. The innovative perspective of arid land agriculture: Essential oilbearing plants as factories for a healthy and sustainable future. Presented in the Annual Meeting of Crop Science Society of America (CSSA), Synergy in Science: Partnering For Solutions, Minneapolis, USA; 15-18 November. ACSESS Digital Library; 2015

[14] Sonwa MM, König WA. Chemical study of the essential oil of Cyperus rotundus. Phytochemistry. 2001;58(5):799-810

[15] Yang L, Chen HX, Gao WY. Advances in studies on chemical constituents in Euphorbia helioscopia and their biological activities. Chinese Traditional and Herbal Drugs. 2007; 38(10):1585

[16] Feizbakhsh A, Aghassi A, Naeemy A. Chemical constituents of the essential oils of Cyperus difformis L. and Cyperus arenarius Retz from Iran. Journal of Essential Oil-Bearing Plants. 2012;15(1):48-52

[17] Nassar MI, Yassine YM, Elshamy AI, El-Beih AA, El-Shazly M, Singab A. Essential oil and antimicrobial activity of aerial parts of Cyperus leavigatus L. (Family: Cyperaceae). Journal of Essential Oil-Bearing Plants. 2015;18(2):416-422

[18] Miyamoto S, Martinez I, Padilla M, Portillo A, Ornelas D. Landscape Plant Lists for Salt Tolerance Assessment. El Paso, Texas: University Agricultural Research and Extension Center; 2004

[19] Karim FM, Dakheel AJ. Salt-Tolerant Plants of the United Arab Emirates; 2006:1-161

[20] Albert-Baskar A, Ignacimuthu S. Chemopreventive effect of Cynodon dactylon (L.) Pers. extract against DMH-induced colon carcinogenesis in experimental animals. Experimental and Toxicologic Pathology. 2010;62(4):423-431

[21] Hameed M, Ashraf M, Naz N, Nawaz T, Batool R, Ahmad M, Ahmad F, Hussain M. Anatomical adaptations of Cynodon dactylon (L.) Pers. from the salt range (Pakistan) to salinity stress. II. Leaf anatomy. Pakistan Journal of Botany. 2013;1(45):133-142

[22] Huang B, Duncan RR, Carrow RN. Drought-resistance mechanisms of seven warmseason turfgrasses under surface soil drying: I. Shoot response. Crop Science. 1997;37(6): $1858-1863$

[23] Shonubi OO, Okusanya OT. The growth and physiological responses of Paspalum vaginatum Sw. and Paspalum scrobiculatum Linn. in relation to salinity. Asian Journal of Plant Sciences. 2007;6(6):949-956 
[24] Nawazish S, Hameed M, Naurin S. Leaf anatomical adaptations of Cenchrus ciliaris L. from the salt range, Pakistan against drought stress. Pakistan Journal of Botany. 2006;38(5): $1723-1730$

[25] Akram NA, Shahbaz M, Ashraf M. Nutrient acquisition in differentially adapted populations of Cynodon dactylon (L.) Pers. and Cenchrus ciliaris L. under drought stress. Pakistan Journal of Botany. 2008;40(4):1433-1440

[26] Goergen E, Daehler CC. Reproductive ecology of a native Hawaiian grass (Heteropogon contortus; Poaceae) versus its invasive alien competitor (Pennisetum setaceum; Poaceae). International Journal of Plant Sciences. 2001;162(2):317-326

[27] Shahid M, Rao NK. Saving the UAE's Halfa grass. Tribulus. 2017;25:69-70

[28] Hashim GM, Almasaudi SB, Azhar E, Al Jaouni SK, Harakeh S. Biological activity of Cymbopogon schoenanthus essential oil. Saudi Journal of Biological Sciences. 2017;24(7): $1458-1464$

[29] Rabe A, Aliero B, Maishanu H, Maikudi H. Influence of different water frequency on the growth and yield of Cymbopogon schoenanthus (Camel Grass). Asian Journal of Research in Agriculture and Forestry. 2018;1(1):1-9

[30] Akhter R, Arshad M. Arid rangelands in the Cholistan desert (Pakistan). Science et Changements Planétaires/Sécheresse. 2006;17(1):210-217

[31] Naz N, Hameed M, Ashraf M, Ahmad R, Arshad M. Eco-morphic variation for salt tolerance in some grasses from Cholistan Desert. Pakistan Journal of Botany. 2009;41(4): 1707-1714

[32] Pitman K, McDonnell R, Dawoud M. EAD (Environmental Agency of Abu Dhabi). Abu Dhabi Water Resources Master Plan. Abu Dhabi, United Arab Emirates: Environment Agency of Abu Dhabi (EAD); 2009

[33] Jongbloed M, Feulner G, Böer B, Western AR. The Comprehensive Guide to the Wild Flowers of the United Arab Emirates. Abu Dhabi, United Arab Emirates: Environmental Research and Wildlife Development Agency; 2003

[34] Western RA. The Flora of the United Arab Emirates: An Introduction. Al Ain, United Arab Emirates: United Arab Emirates University Publications; 1989

[35] Sakkir S, Kabshawi M, Mehairbi M. Medicinal plants diversity and their conservation status in the United Arab Emirates (UAE). Journal of Medicinal Plant Research. 2012;6(7): 1304-1322

[36] Khan TI, Dular AK, Solomon DM. Biodiversity conservation in the Thar Desert; with emphasis on endemic and medicinal plants. The Environmentalist. 2003;23(2):137-144

[37] Shahi AK, Tava A. Essential oil composition of three Cymbopogon species of Indian Thar desert. Journal of Essential Oil Research. 1993;5(6):639-643 
[38] Verón SR, Blanco LJ, Texeira MA, Irisarri JGN, Paruelo JM. Desertification and ecosystem services supply: The case of the Arid Chaco of South America. Journal of Arid Environments. 2017

[39] Schütze N, Kloss S, Lennartz F, Al Bakri A, Schmitz G. Optimal planning and operation of irrigation systems under water resource constraints in Oman considering climatic uncertainty. Environment and Earth Science. 2011;65(5):1511-1521. DOI: 10.1007/s12665-011-1135-4

[40] Salem MA, Al-Zayadneh W, Schulze HF, Cheruth AJ. Effect of nano-hydrophobic sand layer on Bermudagrass (Cynodon spp.) in urban landscaping. Urban Water Journal. 2014; 11(2):167-173 

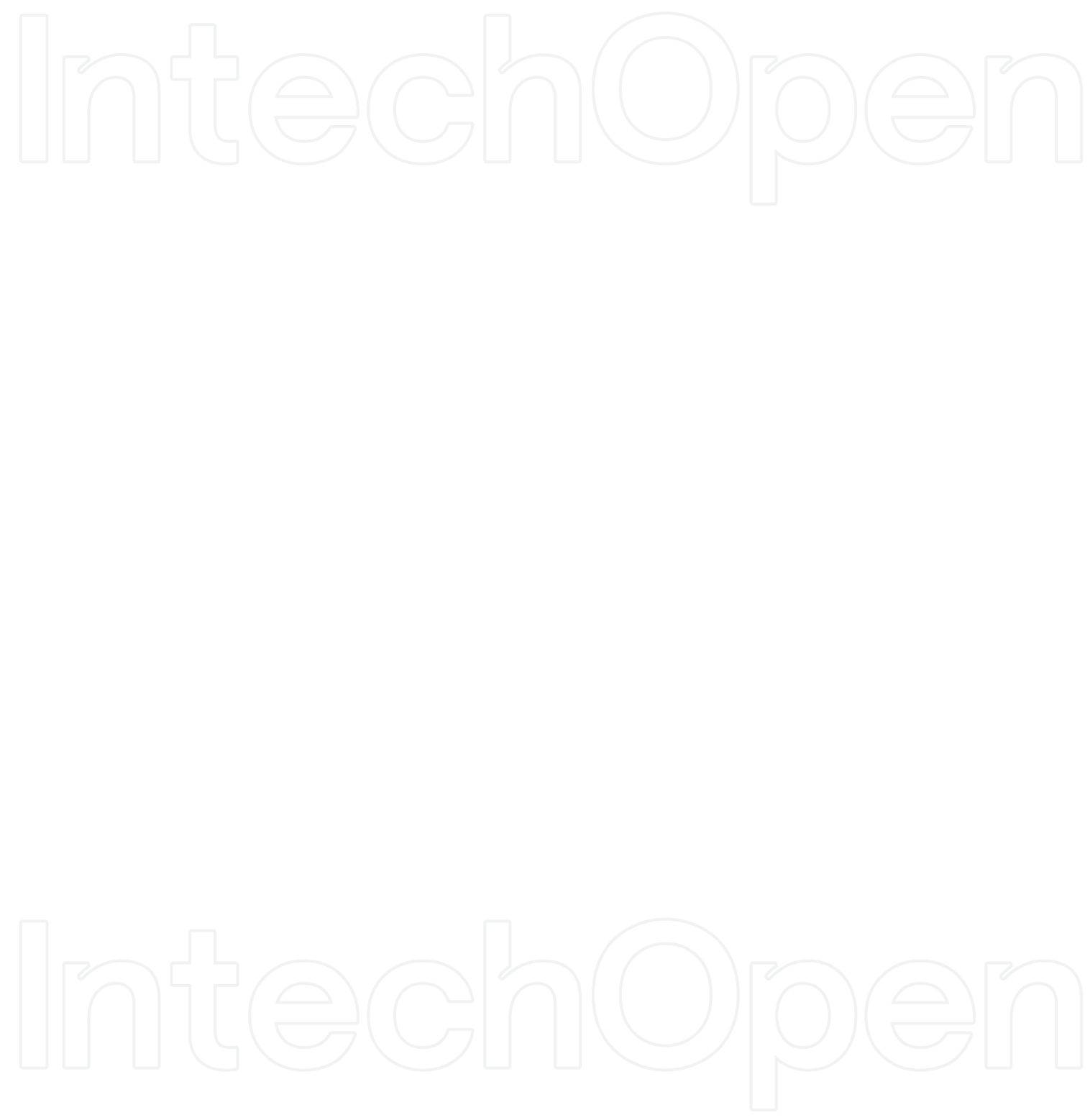


\title{
Potential for Use of a Perennial $\mathrm{C}_{3}$ Grass in a Warm- Temperate Region with Pastures Dominated by $\mathrm{C}_{4}$
} Grasses

\author{
Montgomery W. Alison, William D. Pitman, \\ Glen E. Aiken and Kun-Jun Han
}

Additional information is available at the end of the chapter

http://dx.doi.org/10.5772/intechopen.79231

\begin{abstract}
Tall fescue is a perennial cool-season forage grass utilized over an extensive area of the USA; however, adaptation is limited across the Coastal Plain region of the southeastern states including Louisiana. Stands of the original variety, Kentucky 31, from early plantings either failed to persist or were replaced as adverse effects on grazing livestock by an ergot alkaloid toxin from an association of tall fescue with an endophytic fungus were recognized. Management approaches can moderate the adverse effects allowing productive use of existing tall fescue pastures. Endophyte removal from tall fescue allowed development of useful cultivars for the primary tall fescue growing area, but these endophyte-free cultivars proved to be less persistent in marginal areas such as Louisiana. Recently available varieties with novel, nontoxin-producing endophytes have shown potential in northern Louisiana with stand persistence for 4 years on some sites. Coolseason perennial grass pastures can be realistic components of forage systems in areas such as northern Louisiana. Existing remnant stands can be beneficial with appropriate management, and, as indicated by ongoing research, new novel-endophyte varieties may prove useful on selected sites.
\end{abstract}

Keywords: pastures, cool-season grasses, tall fescue, adaptation, plant persistence, grazing management, fescue toxicosis 


\section{Introduction}

Across northern Louisiana USA, perennial grass pastures support beef cattle production on sites ranging from fertile bottomlands to leached sandy uplands. This area lies within $32-33^{\circ} \mathrm{N}$ and $91-94^{\circ} \mathrm{W}$ providing a long summer growing season for warm-season grasses and a winter dormant period for these grasses of about 5 months each year. The warm-season, perennial grasses bermudagrass (Cynodon dactylon) and bahiagrass (Paspalum notatum) are well adapted and provide the forage base for livestock production. Dormant season forage has typically been provided by hay and/or cool-season annual forages overseeded each autumn on dormant sod of the warm-season pasture grasses. To the north of this area, just above about $35^{\circ} \mathrm{N}$, the cool-season perennial grass, tall fescue (Lolium arundinaceum; synonym Schedonorus arundinaceus; formerly Festuca arundinacea) dominates as the primary pasture grass. From about 1945, the area of use of tall fescue in the United States expanded greatly with development of the variety Kentucky 31 as a widely adapted pasture plant [1]. By the 1960s, tall fescue was recognized as a useful perennial cool-season pasture plant on bottomland soils of northern Louisiana [2]. On sandy loam upland soils of northern Louisiana, evaluations of tall fescue varieties in repeatedly clipped plots resulted in yields of Kentucky 31 of $4400 \mathrm{~kg} / \mathrm{ha}$ per growing season over a 4-year period for a 1955 planting [3]. Average annual production over a 4-year period for Kentucky 31 from a 1958 planting was $5930 \mathrm{~kg} / \mathrm{ha}$. Stands from a 1967 planting of eight tall fescue varieties persisted for only 2 years with average annual yields for Kentucky 31, which was one of the two most productive varieties, of $9130 \mathrm{~kg} / \mathrm{ha}$. Failure to survive the summer period following repeated clipping to an 8-cm stubble height for a period of two to four growing seasons was a common result of the field plot evaluations [3]. Remnant tall fescue stands on sandy loam soils in the area, especially along the bottoms of the often strongly sloping landscape, have survived under grazing for decades. These stands are considered to be predominately of Kentucky 31, which was the primary variety available in the area when most of the tall fescue pasture planting occurred. As tall fescue pastures were developed, toxicity problems were increasingly recognized in the 1970s as documented for the neighboring state, Arkansas [4]. With recognition of this toxicity as a limitation to both calf-crop percentages and weaning weights in addition to the infrequent severe toxicity symptoms, use of tall fescue as a pasture plant in Louisiana decreased to only remnant stands. Management of these remnant tall fescue stands continues to present recurring management questions.

Recent contacts with area cattle producers regarding existing tall fescue in pastures have ranged from a desire to eliminate the plants to an interest in management approaches to improve existing partial stands. Observation of toxicity symptoms in one instance and lack of detectable negative effects in another of close proximity led to assessments of ergot alkaloid levels and seed head suppression in existing tall fescue stands. Ergovaline levels in seed heads of tall fescue in Missouri in late June of $1-5 \mathrm{mg} / \mathrm{kg}$ contrast with levels of $0.3-0.5 \mathrm{mg} / \mathrm{kg}$ for all other plant parts [5]. Thus, reproductive tillers with maturing seed heads can produce very high concentrations of alkaloid toxins. Use of plant growth regulators to seasonally decrease stem development has been identified as a management approach for control of fescue toxicity [6-8]. Applications of metsulfuron-containing herbicides to vegetative and bootstage tall fescue in the spring substantially reduced seed head production [6]. The herbicide 
Chaparral ${ }^{\boxplus \top M}$ suppressed tall fescue seed head emergence, reduced severity of fescue toxicosis [7], and contributed to a higher rate of gain by steers grazing herbicide-treated tall fescue compared to those grazing nontreated pastures [8].

Discovery of the detrimental effects of the endophyte alkaloids on the rate of gain by young growing cattle $[9,10]$ led to development of cultivars identified as endophyte free. Subsequently, reduced competitiveness and decreased plant persistence were found to be associated with reduced endophyte levels of tall fescue pastures in stressful environments [11]. As an approach to provide a useful cool-season perennial pasture option for the lower southeastern USA, Georgia-5 and Jesup were selected for superior persistence and released $[12,13]$ in the 1990s as cultivars with the endemic, toxin-producing endophyte contributing to stand survival. Following initial results in Louisiana verifying the endophyte effects [14], evaluations of these varieties along with their endophyte status and potential management approaches for northern Louisiana were evaluated.

Interest in the novel-endophyte tall fescue varieties in Louisiana increased with marketing of cultivars with the Max Q endophyte resulting in evaluations of Jesup Max Q. Recently, availability of several cultivars of tall fescue with novel, nontoxin-producing endophytes from the commercial seed industry along with marketing of these cultivars led to renewed interest in potential for persistent cool-season pastures in Louisiana. Positive results from evaluations of initial novel endophyte varieties in Louisiana [14] and the lack of negative effects reported for animal responses [15] further justified the continuing assessment of the available varieties of novel endophyte tall fescue.

\section{Materials and methods}

\subsection{Alkaloid levels}

At two farms in northern Louisiana where responses of grazing cattle to tall fescue forage differed, tillers were dug from just below the soil surface with individual tillers removed from the plant crown. When reproductive tillers were present, separate samples of vegetative and reproductive tillers were collected. At each farm, samples were collected from two distinct pasture areas. Each sample collected consisted of 20 individual tillers. Samples were immediately placed on ice and then frozen upon arrival at the lab. For assessment of ergot alkaloid effects, ergovaline, the widely recognized predominant alkaloid associated with fescue toxicosis $[5,16]$, which has been widely used as a measure of fungal endophyte toxin level in tall fescue, was analyzed. Analysis of ergovaline and its stereoisomer, ergovalinine, was by high-performance liquid chromatography fluorescence as described by Yates and Powell [17] and modified by Carter et al. [18].

\subsection{Seed head suppression}

Two locations in a large pasture in Claiborne Parish, Louisiana, USA, where fescue toxicosis symptoms had been observed, were selected for evaluation of effects of Chaparral herbicide on tall fescue seed head emergence. The pasture was stocked continuously with crossbred beef 
cattle during the evaluation period. Paired comparisons with and without application of the herbicide were made at each of the two locations within this pasture. Each of the four experimental units was 0.1 ha in size. Chaparral herbicide was applied to one 0.1 ha experimental unit in each of the two pairs of plots on April 22, 2016. Application rate was $1.46 \mathrm{ml} \mathrm{ha}^{-1}$ plus $0.25 \%$ nonionic surfactant in $187 \mathrm{~L}_{\text {water }} \mathrm{ha}^{-1}$. The number of seed heads was counted within a $0.25 \mathrm{~m}^{2}$ frame at five locations within each experimental unit. Height of mature inflorescences within each frame was also determined. Tillers were obtained from each experimental unit for determination of ergot alkaloid concentration as described above.

\subsection{Endophyte status and grazing management}

Potential for the tall fescue varieties Georgia-5, Jesup, and Kentucky 31 to persist as perennial pasture species in northern Louisiana was evaluated over 3 years from a 1988 drill seeding into a dormant bermudagrass sod. A split-plot treatment arrangement consisted of main plots of grazing management combinations differing during the cool and warm seasons. A factorial combination of either continuous or rotational stocking in the cool season and warm-season management of continuous stocking, rotational stocking, or hay production resulted in six main plot treatments. Each was split into six subplots of the factorial combination of three tall fescue varieties with either the endemic endophyte or no endophyte. These were established in a randomized complete block design with four replications. Warm-season treatments were applied from June through September each year. Cattle numbers were adjusted to maintain a minimal $6 \mathrm{~cm}$ forage stubble height. Stands were assessed each January by determining presence or absence of fescue plants every $3 \mathrm{~cm}$ along a 3-m transect in each plot.

\subsection{Jesup grazing management}

Plantings of Jesup Max $Q$ tall fescue on a seasonally waterlogged Latanier clay soil in northwest Louisiana and a Gigger silt loam soil in northeast Louisiana were subjected to grazing treatments. The planting in northwest Louisiana was drill-seeded in the autumn of 2008, while the northeast Louisiana stand was from a 2006 planting that had been lightly grazed periodically. Treatments imposed were a factorial combination of two spring grazing termination dates (May 1 and June 1) with grazing treatments of no summer grazing and periodic summer grazing to harvest growth of associated warm-season grass, primarily summer annuals dominated by crabgrass (Digitaria sanguinalis). Fertilization of tall fescue in this factorial arrangement of treatments was at $38 \mathrm{~kg} /$ ha of nitrogen each spring. In addition, three control treatments of no nitrogen fertilizer and $76 \mathrm{~kg} / \mathrm{ha}$ of nitrogen with the periodic summer grazing and a continuously grazed treatment with $38 \mathrm{~kg} / \mathrm{ha}$ of nitrogen fertilizer were also imposed. Cool-season grazing was from October through May in 2009-2010 and 2010-2011. Periodic tall fescue stand assessments were made by counting the number of $0.1 \times 0.1 \mathrm{~m}$ cells containing the grass in a 1- $\mathrm{m}^{2}$ divided sample quadrat. Stands were evaluated on March 22, 2010 and January 31, 2012 with herbage mass sampled on November 30, 2009.

\subsection{Tall fescue variety/novel endophyte evaluation}

On October 29, 2013, five commercially available novel-endophyte inoculated varieties of tall fescue were planted near the site of the Jesup grazing evaluation in northwest Louisiana. 
Along with the varieties DuraMax Gold tall fescue with Armor ${ }^{\circledast^{\mathrm{TM}}}$ endophyte, Estancia tall fescue with ArkShield ${ }^{\AA^{\mathrm{TM}}}$ Technology endophyte, Martin 2 tall fescue with Protek ${ }^{\otimes^{\mathrm{TM}}}$ endophyte, Texoma tall fescue with Max Q II ${ }^{{ }^{\mathrm{TM}}}$ endophyte, and Tower tall fescue with Protek ${ }^{{ }^{\mathrm{TM}}}$ endophyte, Kentucky 31 with the naturally occurring (endemic), toxin-producing endophyte was included as a check. Plantings were in a randomized complete block design with three replications of plots each $12 \times 80 \mathrm{~m}$ on an area dominated by Moreland silty clay loam soil with a substantial area of Latanier clay across much of one replication. The area was grazed periodically as forage was available over the next 4 years with grazing restricted to the cool season. To compare potential productivity among varieties, an area of $1 \mathrm{~m}^{2}$ was clipped to an 8-cm stubble height from each plot in a selected area with a dense stand on January 31, 2018 before grazing was initiated. Ratings of stand density were made on March 13, 2018 following an early season grazing period. Visual ratings of tall fescue stand density across only the Moreland soil area of each plot were based on a scale of 0 for no tall fescue to 9 for a complete, dense stand with no competing vegetation present.

\section{Results and discussion}

\subsection{Alkaloid levels}

Ergovaline concentrations in vegetative tillers from these Louisiana pastures ranged from a low of $0.08 \mathrm{mg} / \mathrm{kg}$ in April of 2017 to a high of $1.61 \mathrm{mg} / \mathrm{kg}$ in October of 2015 (Figure 1). Both of these divergent samples were from the pasture location where no fescue toxicity symptoms were observed. Ergovalinine concentration was consistently lower than that of ergovaline but followed a generally similar pattern of fluctuation throughout the sampling period. The average ergovaline concentrations of 0.65 and $0.70 \mathrm{mg} / \mathrm{kg}$ for the two pastures exceeded the highest level of $0.464 \mathrm{mg} / \mathrm{kg}$ reported by Belesky et al. [19] for tall fescue grown at Watkinsville, Georgia, USA. From evaluations at three Georgia locations during 2 years [20], only samples from Athens, Georgia in one of the 2 years produced a higher average ergovaline concentration than that of the Louisiana samples. Ergovaline concentration can be affected by environmental and management conditions including season of the year, nitrogen fertilizer, and moisture deficit [5, 19-21]. Defoliation intensity can also affect production of this toxin [22]. As illustrated in Figure 1, substantial variation in ergot alkaloid concentration occurred among sampling dates and between locations in the two Louisiana pastures. In contrast to the distinct seasonal pattern with peak ergovaline concentrations in spring and autumn reported by Belesky et al. [19], the variation in Louisiana pasture samples revealed no distinct seasonal pattern. Variation in ergot alkaloid production in these pastures is perhaps primarily influenced by the rather drastic weather conditions and stocking management which resulted in substantial variation in available forage and plant growth.

Consumption of ergovaline was estimated to range from 4.2 to $6.0 \mathrm{mg} /$ day during June in a Missouri evaluation before decreasing to a range of 1.1-2.8 mg/day in August [16]. Forage concentrations of ergovaline in Kentucky 31 tall fescue forage providing these daily intake levels ranged from 0.154 to $0.506 \mathrm{mg} / \mathrm{kg}$. Although clinical symptoms of toxicosis were not reported, reductions in milk production, calf gain, and cow body weight were reported, as 

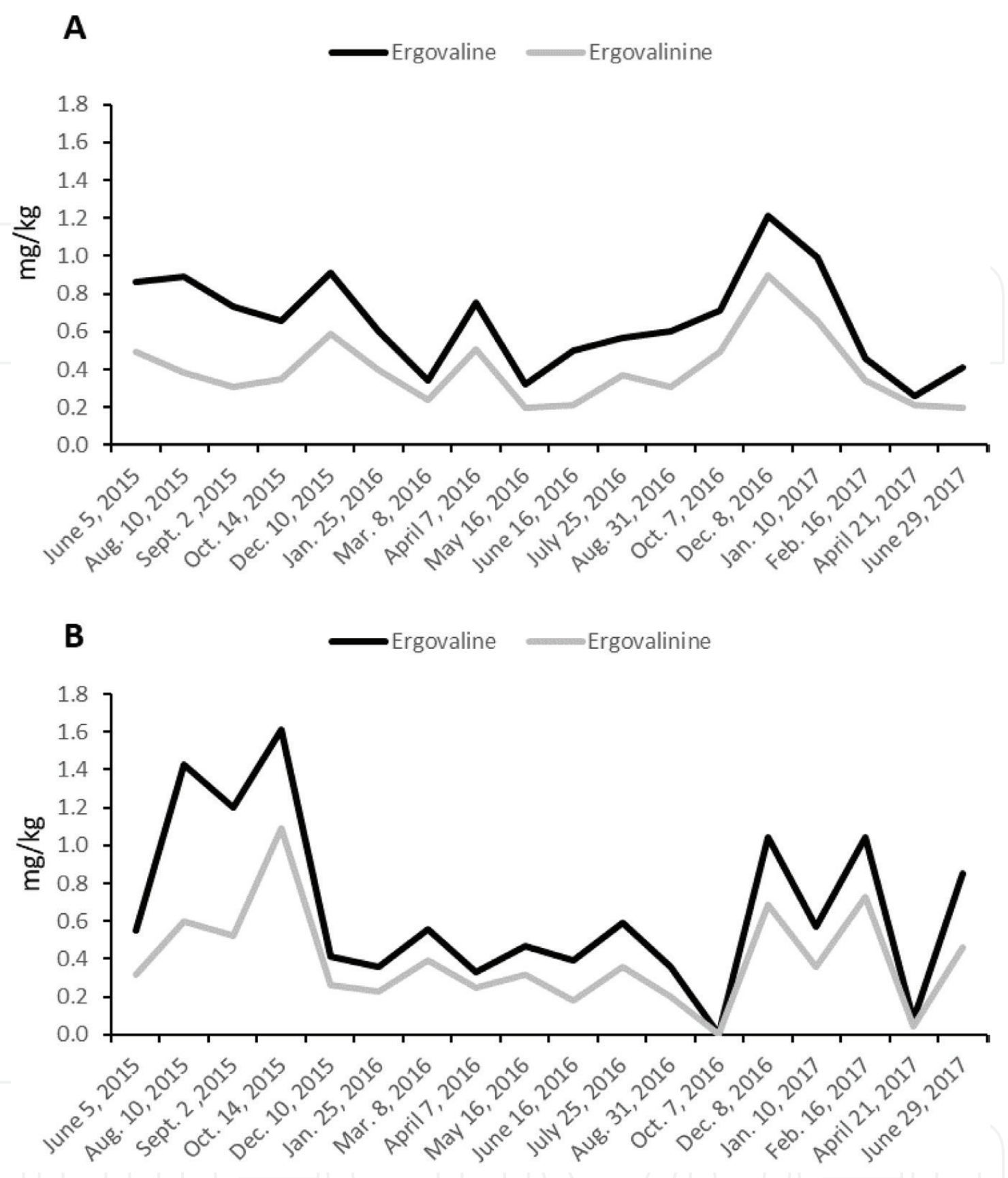

Figure 1. Ergot alkaloid concentrations in vegetative tillers from remnant tall fescue stands in (A) central and (B) southern locations in Claiborne Parish, Louisiana, USA.

well as reduced forage intake in August, in comparison to cattle grazing endophyte-free tall fescue pastures [16]. Some questions have been presented about the adequacy of ergovaline as the sole measure of ergot alkaloid concentration in tall fescue. Different patterns of concentration of ergovaline and total ergot alkaloids in distribution within a tall fescue canopy and with forage conservation methods have been reported [23, 24] with Roberts et al. [23] suggesting that ergovaline alone may not fully reflect animal performance responses to the endophyte. Rogers et al. [25] further determined that management to reduce effects of ergot alkaloids on livestock performance depended upon whether ergovaline or total alkaloids are the primary causative agents of fescue toxicosis. Potential for synergistic effects of multiple ergot alkaloid 
compounds on vasoconstriction was also reported [26]. Foote et al. [27] reported that vasoconstriction, a primary animal response to the toxin, was primarily a result of ergovaline concentration of forage consumed by grazing livestock. Levels of ergovaline and ergovalinine detected in both Louisiana pastures were at least periodically high enough to produce fescue toxicosis symptoms, even though other effective alkaloids may also have been present. The lack of visual toxicosis symptoms at one of the locations was not associated with lack of toxic alkaloid concentrations in the tall fescue forage, even though additional toxic alkaloid compounds may have been present.

With alkaloid levels periodically high in both Louisiana pastures and animal effects in only one of these, further assessment is needed. One location involved leased land which had not been recently grazed and tall fescue growth was mature and rank. This tall fescue forage was essentially the only grazing available during the initial cool season for these cattle, which were also alkaloid toxin-naïve (not previously exposed to such toxic forage). In addition, cattle in the pasture not visually affected by toxicity symptoms were crossbred cattle with a substantial proportion of Brahman breeding, while the herd where symptoms were observed was of less uniform breeding and generally less Brahman composition. Brahman cattle have been suggested to provide less susceptibility to fescue toxicosis associated with their greater heat tolerance $[28,29]$. Thus, both cattle aspects and pasture condition may have contributed to differences in toxicity symptoms observed. This is consistent with observations in Arkansas where "fescue foot" symptoms were reported in cattle stocked on previously ungrazed "soilbank program" land being returned to production, even though these symptoms were not frequently observed in most tall fescue pastures in the area [4].

\subsection{Seed head suppression}

Evaluations of Chaparral treatment of tall fescue produced visible decreases in tall fescue seed head emergence (Table 1) and changes in plant species composition of mixed tall fescue stands with diverse broadleaf weeds and bahiagrass, which were substantially reduced by the herbicide. In addition to the substantial reduction in number of seed heads emerging following treatment, height of seed heads was also reduced (Table 1) with greatly reduced production of stem material. Ergot alkaloid concentrations were similar between the two treatments in both vegetative and reproductive tillers (Table 2) but the reduction in number of reproductive tillers by herbicide application should reduce the amount of alkaloid ingested

\begin{tabular}{llll}
\hline & \multicolumn{2}{l}{ Range of seed head stem heights } \\
\hline & Seed head & Low & High \\
\hline Nhaparral $^{\circledR \mathrm{TM}}$ & No./m & $\mathrm{cm}$ & $32 \mathrm{a}$ \\
Not treated & $42 \mathrm{a}^{*}$ & $14 \mathrm{a}$ & $69 \mathrm{~b}$ \\
\hline
\end{tabular}

Chaparral $^{\circledast^{\mathrm{TM}}}$ (Trademark of the Dow Chemical Company) was applied on April 22, 2016 at the rate of $146 \mathrm{ml} \mathrm{ha}^{-1}+0.25 \%$ nonionic surfactant in $187 \mathrm{~L}$ water $\mathrm{ha}^{-1}$. Means within a column followed by a common letter do not differ significantly $\underline{(P<0.05)}$

Table 1. Effect of Chaparral ${ }^{\circledR \mathrm{TM}}$ herbicide on tall fescue seed head formation and development. 


\begin{tabular}{lllll}
\hline & Vegetative tillers & & \multicolumn{2}{l}{ Reproductive tillers } \\
\hline Treatment & Ergovaline & Ergovalinine & Ergovaline & Ergovalinine \\
\hline Chaparral $^{\mathbb{1}^{\mathrm{TM}}}$ & 0.42 & 0.27 & 0.54 & 0.29 \\
Not treated & 0.41 & 0.21 & 0.49 & 0.29 \\
\hline
\end{tabular}

Chaparral $^{\oplus \mathrm{TM}}$ (Trademark of the Dow Chemical Company) was applied on April 22, 2016 at the rate of $146 \mathrm{ml} \mathrm{ha}^{-1}+0.25 \%$ nonionic surfactant in $187 \mathrm{~L}$ water ha ${ }^{-1}$.

Table 2. Ergot alkaloid concentrations $\left(\mathrm{mg} / \mathrm{kg}\right.$ ) in response to Chaparral ${ }^{\circledR T M}$ herbicide application to tall fescue pasture (no significant differences between treatments, $\boldsymbol{P}>0.05$ ).

by grazing livestock. At an additional northern Louisiana location with a dense, ungrazed tall fescue stand, seed head density was reduced by this herbicide treatment of plants primarily in the boot stage. Seed heads were, however, still prevalent in the stand indicating that adequate opportunity for livestock consumption of toxin may persist in tall fescue pasture treated at this stage and allowed excessive deferment from grazing even with such seed head suppression.

\subsection{Endophyte status and grazing management}

At the end of 3 years, it was obvious that endophyte infection was necessary for stand persistence of the varieties Georgia-5, Jesup, and Kentucky 31 on this site as the endophyte-free varieties provided less than $10 \%$ stand survival. For the endophyte-infected varieties, both Georgia-5 and Jesup were more persistent than Kentucky 31 (Figure 2), with Jesup providing the highest level of persistence at a little more that $50 \%$ stand survival. Continuous stocking of endophyte-infected tall fescue during the summer period provided the best stand survival (Figure 3), although considerable stand loss occurred in all treatments. Continuous stocking was beneficial during the warm season because little grazing of tall fescue occurred and warm-season grass was highly competitive during periods without grazing. Warm-season grass height of $15-20 \mathrm{~cm}$ during the summer before each rotational grazing period or hay harvest resulted in substantial shading of the tall fescue, which produced only minimal growth during this period. Grazing management, either continuous or rotational stocking, during other periods of the year did not substantially affect tall fescue survival.

Even though both of the endophyte-infected varieties provided better persistence than did Kentucky 31 and Kentucky 31 had persisted for years on some sites, widespread use of these varieties did not occur, even on more favorable sites. Establishment difficulties were found to be limitations for plantings into existing warm-season grass sod under less-than-optimal conditions. Selection of the more moist Coastal Plain sites, management of competition, and soil fertility, particularly phosphorus, were reported to be critical aspects for establishment of Georgia 5 on sandy Coastal Plain sites in Louisiana [30]. Despite the potential for Georgia-5 and Jesup to fill a gap in pasture systems on appropriate sites in the region, these cultivars were not widely planted in Louisiana.

\subsection{Jesup grazing management}

At initiation of grazing in autumn 2009, the experimental areas at both locations were essentially complete stands of tall fescue with similar fescue growth between locations and among 


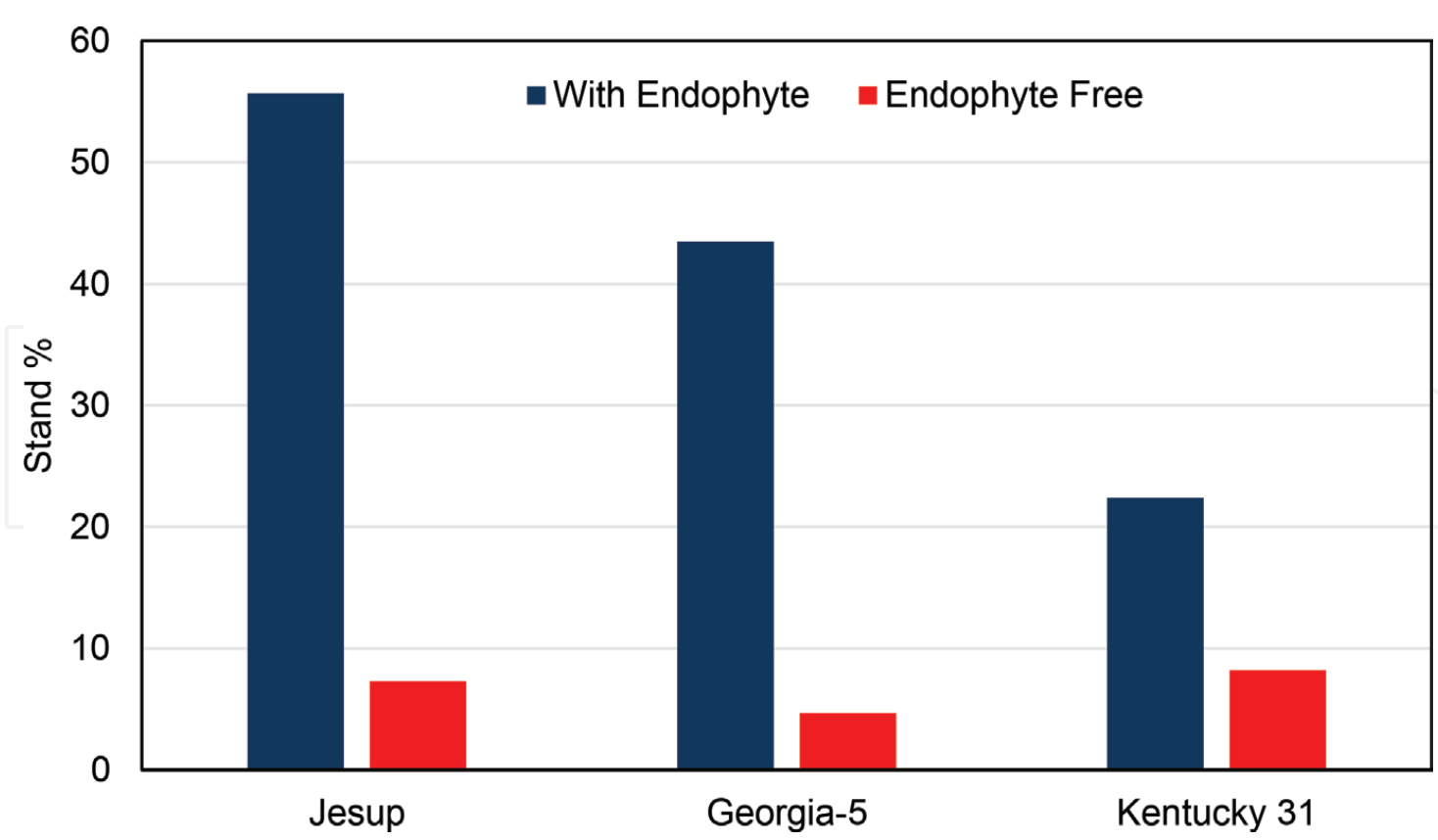

Figure 2. Effect of endophyte infection on stands of tall fescue varieties planted in a perennial warm-season grass sod and subjected to various grazing and hay management practices during the previous 3 years.

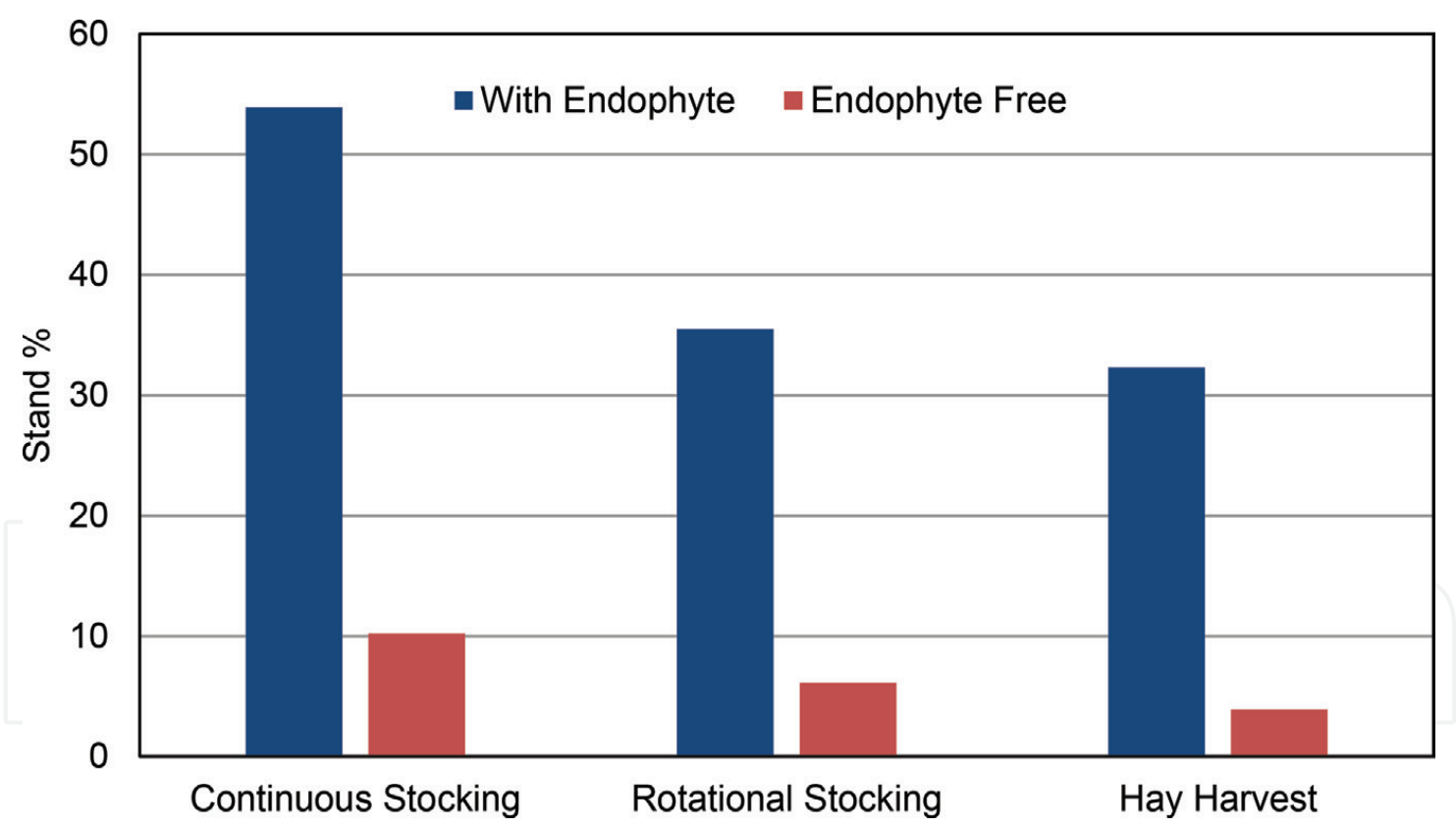

Figure 3. Effect of 3 years of light continuous stocking, rotational stocking, or hay harvests during the summer periods on stands of tall fescue planted in a perennial warm-season grass sod.

plots (Table 3). By March of 2010, very little change had occurred in these stands with no difference among treatments, which ranged from 95 to $98 \%$ tall fescue. Tall fescue stands decreased markedly at both locations during the relatively dry summer of 2011. Stands at the northwest location ranged from only 6 to 25\% tall fescue at the end of January 2012, even though no grazing occurred after September 2011. Both treatments at this location with grazing terminated on May 1 had lower tall fescue cover percentages (6\%) than did similar 


\begin{tabular}{lllll}
\hline Spring N (kg/ha) & Spring grazing terminated & Summer grazing* & \multicolumn{2}{l}{ Location (Louisiana, USA) } \\
\cline { 4 - 5 } & & & NW & \multicolumn{1}{l}{ NE } \\
\cline { 3 - 5 } & & & Forage mass (kg/ha) \\
\hline 0 & 1-Jun & Periodically stocked & 4915 & 5038 \\
38 & 1-Jun & None & 5698 & 4955 \\
38 & 1-Jun & Periodically stocked & 4960 & 4840 \\
\hline 38 & 1-May & None & 4719 & 4726 \\
38 & 1-May & Periodically stocked & 4905 & 4761 \\
38 & None & Continuously stocked & 4950 & 5237 \\
76 & 1-Jun & Periodically stocked & 5918 & 5314 \\
\hline
\end{tabular}

*Summer grazing describes grazing during the summer period (June-September). Periodically stocked refers to light stocking during various times to graze volunteer annual summer forages but minimize grazing of tall fescue.

*No significant differences $(P>0.05)$ in forage mass between locations or among grazing treatments.

Table 3. Forage dry matter production by late November from Jesup MaxQ tall fescue at two locations in Louisiana.

treatments with grazing terminated on June 1 (average of 19\% cover). The numerically highest tall fescue cover of $25 \%$ was on the ungrazed control treatment. Whether or not warm-season grass was grazed during the summer, the early grazing termination date was detrimental rather than beneficial as expected. Grazing until June 1 may have reduced competition from early growth of warm-season grass more than any adverse effects on the tall fescue during the month of May. None of the treatments evaluated provided sufficient stand survival at either location to indicate adaptation of Jesup Max $Q$ tall fescue to these sites. No survival response was detected over the range of $0-76 \mathrm{~kg} / \mathrm{ha}$ of nitrogen fertilizer annually.

\subsection{Tall fescue variety/novel endophyte evaluation}

Visual observation over the years indicated substantial stands of all entries of tall fescue persisting across most of the planted area. By the summer of 2017, a visually distinct demarcation of the boundary of the two soil types was apparent with all varieties persisting on the Moreland silty clay loam, except in some nondrained depressional areas, and very little of any variety persisting on the Latanier clay. Thus, both lack of drainage in depressional areas and the water-logging prone Latanier clay appear to provide unacceptable sites for tall fescue. This clay soil limitation may have been a key aspect of lack of survival by Jesup Max Q in the earlier evaluation of grazing and nitrogen fertilization treatments at this location.

Herbage mass available for grazing in January 2018 ranged from $1485 \mathrm{~kg} / \mathrm{ha}$ for Tower to $1970 \mathrm{~kg} / \mathrm{ha}$ for DuraMax; however, substantial variability among replications resulted in no significant difference among varieties (Table 4). It is noteworthy that the variety producing the numerically highest yield, DuraMax Gold, was developed from the winter-productive cultivar AU Triumph [31]. AU Triumph produced twice as much forage during the winter growth period on the Alabama gulf coast as did Kentucky 31 in early trials [32]. Thus, the 


\begin{tabular}{|c|c|c|c|c|c|}
\hline \multirow{3}{*}{ Tall fescue variety } & \multirow{3}{*}{ Endophyte } & \multirow{2}{*}{\multicolumn{2}{|c|}{$\begin{array}{l}\text { Forage mass } \\
\text { Jan. } 31,2018\end{array}$}} & \multicolumn{2}{|c|}{ Stand rating* } \\
\hline & & & & Mar & \\
\hline & & \multicolumn{4}{|c|}{$\mathrm{kg} / \mathrm{ha}$} \\
\hline DuraMax Gold & Armor $^{\circledast \mathrm{TM}}$ & 1970 & $a^{* *}$ & 7.7 & $\mathrm{a}$ \\
\hline Estancia & ArkShield $^{\oplus \mathrm{TM}}$ & 1510 & $\mathrm{a}$ & 6.7 & $\mathrm{ab}$ \\
\hline Kentucky 31 & Naturally occurring & 1635 & $\mathrm{a}$ & 7.5 & a \\
\hline Martin 2 & Protek $^{\oplus \mathrm{TM}}$ & 1593 & a & 7.0 & a \\
\hline Texoma & MaxQ II ${ }^{\oplus T M}$ & 1593 & $\mathrm{a}$ & 8.0 & $a$ \\
\hline Tower & Protek $^{\oplus \mathrm{TM}}$ & 1485 & a & 5.5 & $\mathrm{~b}$ \\
\hline
\end{tabular}

*Stand ratings were on a scale of 0 for no tall fescue to 9 for a complete, dense stand.

*Means within a column followed by a common letter do not differ significantly $(P<0.05)$.

Table 4. Forage mass and stand ratings of novel endophyte tall fescue varieties in early 2018 from a 2013 planting on bottomland soil in northwest Louisiana.

indication of potentially superior cool-season productivity for DuraMax requires further evaluation. As with herbage mass, Tower provided the lowest stand rating (5.5) on March 13, 1018 (Table 4). Four entries, DuraMax Gold, Kentucky 31, Martin 2, and Texoma, were similar in stand rating averaging 7.5. Estancia was intermediate with a stand rating of 6.7. The numerically highest stand rating for Texoma is also consistent with selection of this cultivar for persistence in a marginal environment for the species [33] with further evaluation of this planting expected to provide further detection of differences in persistence among varieties.

Fiber components and CP were similar among varieties from the January 2018 herbage samples (Table 5) indicating that forage quality is generally similar for these varieties. Increased $\mathrm{Mg}$ levels in herbage has been suggested as a possible means to reduce grass tetany potential, and HiMag Tall Fescue Germplasm was developed as a cool-season pasture option to reduce

\begin{tabular}{llllll}
\hline Variety $^{*}$ & Endophyte & CP & ADF & NDF & Mg \\
\hline & & $\%$ & & & \\
\hline DuraMax Gold & Armor $^{\circledR T M}$ & 12.9 & 33.41 & 60.84 & 0.29 \\
Estancia & ArkShield $^{\circledR T M}$ & 13.1 & 33.52 & 59.79 & 0.34 \\
KY31 & Endemic $^{*}$ & 12.8 & 34.02 & 60.11 & 0.30 \\
Martin2 & Protek $^{\oplus \mathrm{TM}}$ & 13.8 & 32.10 & 57.60 & 0.32 \\
Texoma & MaxQ II $^{\oplus \mathrm{TM}}$ & 12.7 & 34.44 & 60.38 & 0.32 \\
Tower & Protek $^{\oplus \mathrm{TM}}$ & 13.5 & 32.58 & 57.79 & 0.32 \\
\hline
\end{tabular}

"No significant differences $(P>0.05)$ in forage quality parameters were detected among varieties.

Table 5. Forage quality parameters of tall fescue varieties with novel endophytes from a winter harvest at the northwest Louisiana location. 
grass tetany hazard [34]. Estancia was developed from the HiMag germplasm [31], and was highest in Mg ranking among the varieties. Despite lack of statistically significant differences among varieties in $\mathrm{Mg}$ levels from our single harvest of growth, the limited results justify further evaluation.

\section{Implications for use of tall fescue in a warm-temperate environment}

While existing areas of tall fescue with potential to produce toxic alkaloid compounds provide distinct limitations for livestock production, management approaches for effective use of such pastures are available. Aiken and Strickland [22] provided several strategies to minimize adverse effects of such pastures. These include use of heavy grazing intensities, chemical suppression of seed head emergence, use of these pastures in seasons other than late spring and summer, and dilution of dietary alkaloids by interseeding clovers or feeding supplements. Variations of these strategies are perhaps the reason that adverse effects on grazing livestock from the few remaining Kentucky 31 pastures across northern Louisiana are only rarely observed. Thus, with appropriate management, existing pastures of Kentucky 31 tall fescue in the region can be productive components of pasture systems, even though improved options appear to be available for new plantings of perennial cool-season pasture on selected sites.

Endophyte-free tall fescue varieties have proven to be insufficiently adapted for planting as perennial pasture plants even on the better sites in Louisiana. Among the varieties with toxinproducing-endophytes, better adapted varieties than Kentucky 31 have been developed, but planting of these varieties has been very limited. In contrast to the recommendations for the primary tall fescue growing area not to graze tall fescue pastures during summer to reduce effects of the toxin-producing endophyte [22], in northern Louisiana, light stocking is beneficial because tall fescue growth is minimal and stocking rate can be managed to reduce competition from preferentially grazed warm-season grasses. The novel, nontoxin-producing endophytes appear to provide improved options for development of tall fescue varieties adapted to northern Louisiana.

Current information indicates that several varieties of tall fescue with different novel endophytes may provide useful options, at least on selected sites. Whether any of these varieties may be as persistent over periods of decades as Kentucky 31 has been on the most favorable sites has not been determined. Both drought-prone sandy uplands and seasonally waterlogged clay bottomlands do not appear to be suitable sites for tall fescue in this region. Loss of stands in clipping evaluations of several early varieties including Kentucky 31 on upland soils and subsequent survival of Kentucky 31 from plantings in nearby pastures indicate that both site and extent of defoliation may be important determinants of stand survival. With plantings planned for only a few years of productive life, such as may be appropriate for cropping systems including a soil health building phase, selection among appropriate varieties for yield potential would be useful. For long-term pasture plantings with no planned 
termination date, selection for persistence may be more beneficial than short-term differences in productivity among the generally productive varieties. Developing forage systems with perennial grass pastures available for grazing in both the warm season and cool season in this region appear to be realistic goals with selection of appropriate sites and the best adapted tall fescue variety. Several of the recently available novel-endophyte varieties provide promise but require additional evaluation.

\section{Author details}

Montgomery W. Alison ${ }^{1 *}$, William D. Pitman², Glen E. Aiken ${ }^{3}$ and Kun-Jun Han ${ }^{4}$

*Address all correspondence to: walison@agcenter.lsu.edu

1 Louisiana State University Agricultural Center, Macon Ridge Research Station, Winnsboro, Louisiana, USA

2 Louisiana State University Agricultural Center, Hill Farm Research Station, Homer, Louisiana, USA

3 Institute of Food and Agricultural Sciences, North Florida Research and Education Center, University of Florida, Quincy, Florida, USA

4 Department of Plant, Environmental, and Soil Sciences, Louisiana State University, Baton Rouge, Louisiana, USA

\section{References}

[1] Wheeler WA, Hill DD. Grassland Seeds. Princeton. New Jersey: D. Van Nostrand; 1957

[2] Rabb JL, Willis LD, Mondart CL. Miscellaneous feed, forage, and nursery crops. In: Annual Progress Report. Bossier City, Louisiana: Red River Valley Agricultural Experiment Station; 1966. pp. 47-49

[3] Eichhorn MM, Johns DM. Fescuegrass performance trials. In: 1981 Agronomy Research Report. Homer, Louisiana: North Louisiana Hill Farm Experiment Station; 1981. pp. 235-239

[4] Daniels LB. Historical perspective of fescue toxicosis in Arkansas. In: Proceedings of the Arkansas Fescue Toxicosis Conference. Fayetteville, Arkansas: Arkansas Agricultural Experiment Station; 1989. pp. 1-6

[5] Rottinghaus GE, Garner GB, Cornell CN, Ellis JL. HPLC method for quantitating ergovaline in endophyte-infested tall fescue: Seasonal variation of ergovaline levels in stems with leaf sheaths, leaf blades, and seed heads. Journal of Agricultural and Food Chemis-try. 1991;39:112-115. DOI: 10.1021/jf00001a022 
[6] Sather BC, Roberts CA, Bradley KW. Influence of metsulfuron-containing herbicides and application timings on tall fescue seedhead production and forage yield. Weed Technology. 2013;27:34-40. DOI: 10.1614/WT-D-12-00043.1

[7] Aiken GE, Witt WW, Kagan IA. Chaparral herbicide applications for suppression of seedhead emergence in tall fescue pastures and possible alleviation of fescue toxicosis. In: 2010 American Forage and Grasslands Council Conference Proceedings. Available from: www.afgc.org/proceedings/2010/5.pdf. [Accessed: 2018-03-30]

[8] Aiken GE, Goff BM, Witt WW, Kagan IA, Sleugh BB, Burch PL, Schrick FN. Steer and plant responses to chemical suppression of seedhead emergence in toxic endophyteinfected tall fescue. Crop Science. 2012;52:960-969. DOI: 10.2135/cropsci2011.07.0377

[9] Hoveland CS, Haaland RL, King CC, Anthony WB, Clark EM, McGuire JA, Smith LA, Grimes HW, Holliman JL. Association of Epichloe typhina fungus and steer performance on tall fescue pasture. Agronomy Journal. 1980;72:1064-1065. DOI: 10.2134/agronj1980.0 0021962007200060048x

[10] Hoveland CS, Schmidt SP, King CC, Odom JW, Clark EM, McGuire JA, Smith LA, Grimes HW, Holliman JL. Steer performance and association of Acremonium coenophialum fungal endophyte on tall fescue pasture. Agronomy Journal. 1983;75:821-824. DOI: 10.2134/agro nj1983.00021962007500050021x

[11] Read JC, Camp BJ. The effect of the fungal endophyte Acremonium coenophialum in tall fescue on animal performance, toxicity, and stand maintenance. Agronomy Journal. 1986;78:848-850. DOI: 10.2134/agronj1986.00021962007800050021x

[12] Bouton JH, Gates RN, Hill GM, Owsley M, Wood DT. Registration of 'Georgia 5' tall fescue. Crop Science. 1993;33:1405. DOI: 10.2135/cropsci1993.0011183X00330060059x

[13] Bouton JH, Duncan RR, Gates RN, Hoveland CS, Wood DT. Registration of 'Jesup' tall fescue. Crop Science. 1997;37:1011-1012. DOI: 10.2135/cropsci1997.0011183X003700030065x

[14] Hopkins AA, Alison MW. Stand persistence and animal performance for tall fescue endophyte combinations in the south central USA. Agronomy Journal. 2006;98:1221-1226. DOI: 10.2134/agronj2006.0007

[15] Burns JH, Fisher DS, Rottinghaus GE. Grazing influences on mass, nutritive value, and persistence of stockpiled Jesup tall fescue without and with novel and wild-type fungal endophytes. Crop Science. 2006;46:1898-1912. DOI: 10.2135/cropsci2005.09-0327

[16] Peters CW, Grigsby KN, Aldrich CG, Paterson JA, Lipsey RJ, Kerley MS, Garner GB. Performance, forage utilization, and ergovaline consumption by beef cows grazing endophyte fungus-infected tall fescue, endophyte fungus-free tall fescue, or orchardgrass pastures. Journal of Animal Science. 1992;70:1550-1561. DOI: 10.2527/1992.7051550x

[17] Yates SG, Powell RG. Analysis of ergopeptine alkaloids in endophyte-infected tall fescue. Journal of Agricultural and Food Chemistry. 1988;36:337-340. DOI: 10.1021/jf00091a040 
[18] Carter JM, Aiken GE, Dougherty CT, Schrick FN. Steer responses to feeding soybean hulls and steroid hormone implantation on toxic tall fescue pasture. Journal of Animal Science. 2010;88:3759-3766. DOI: 10.2527/jas.2009-2536

[19] Belesky DP, Stuedemann JA, Plattner RD, Wilkinson SR. Ergovaline alkaloids in grazed tall fescue. Agronomy Journal. 1988;80:209-212. DOI: 10.2134/agronj1988.0002196200800 $0020014 x$

[20] Agee CS, Hill NS. Ergovaline variability in Acremonium-infected tall fescue due to environment and plant genotype. Crop Science. 1994;34:221-226. DOI: 10.2135/cropsci1994.0 011183X003400010040x

[21] Arechavaleta M, Bacon CW, Plattner RD, Hoveland CS, Radcliffe DE. Accumulation of ergopeptide alkaloids in symbiotic tall fescue grown under deficits of soil water and nitrogen fertilizer. Applied and Environmental Microbiology. 1992;58:857-861

[22] Aiken GE, Strickland JR. Managing the tall fescue-fungal endophyte symbiosis for optimum forage-animal production. Journal of Animal Science. 2013;91:2369-2378. DOI: 10.2527/jas.2012-5948

[23] Roberts CA, Kallenbach RL, Rottinghaus GE, Hill NS. Ergovaline and ergot alkaloid concentrations change in conserved tall fescue. Online. Forage and Grazinglands. 2011. DOI:10.1094/FG-2011-1013-01-RS

[24] Kenyon SL, Roberts CA, Kallenbach RL, Lory JA, Kerley MS, Rottinghaus GE, Hill NS, Ellersieck MR. Vertical distribution of ergot alkaloids in the vegetative canopy of tall fescue. Crop Science. 2018;58:925-931. DOI: 10.2135/cropsci2017.03.0202

[25] Rogers WM, Roberts CA, Andrae JG, Davis DK, Rottinghaus GE, Hill NS, Kallenbach RL, Spiers DE. Seasonal fluctuation of ergovaline and total ergot alkaloid concentrations in tall fescue regrowth. Crop Science. 2011;51:1291-1296. DOI: 10.2135/cropsci2010.07.0402

[26] Klotz JL, Kirch BH, Aiken GE, Bush LP, Strickland JR. Effects of selected combinations of tall fescue alkaloids on the vasoconstrictive capacity of fescue-naïve bovine lateral saphenous veins. Journal of Animal Science. 2008;86:1021-1028. DOI: 10.2527/jas.2007-0576

[27] Foote AP, Harmon DL, Brown KR, Strickland JR, McLeod KR, Bush LP, Klotz JL. Constriction of bovine vasculature caused by endophyte-infected tall fescue seed extract is similar to pure ergovaline. Journal of Animal Science. 2012;90:1603-1609. DOI: 10.2527/ jas.2011-4513

[28] Browning R. Physiological responses of Brahman and Hereford steers to an acute ergotamine challenge. Journal of Animal Science. 2000;78:124-130. DOI: 10.2527/2000.781124x

[29] Browning R, Thompson FN. Endocrine and respiratory responses to ergotamine in Brahman and Hereford steers. Veterinary and Human Toxicology. 2002;44:149-154

[30] Pitman WD. Establishment of Tall Fescue on West Louisiana Coastal Plain Soils, Bulletin Number 859. Baton Rouge, Louisiana: Louisiana Agricultural Experiment Station 
[31] Smith SR, Phillips T. Novel Endophyte Varieties: What's the Difference. Lexington, Kentucky: University of Kentucky. Available from: https:uknowledge.uky.edu/cgi/viewcontent.cgi?article=1003\&context=forage_kca [Accessed 2018-03-19]

[32] Hoveland CS, Haaland RL, Berry CD, Pedersen JF, Schmidt SP, Harris RR. Triumph-A New Winter-Productive Tall Fescue Variety, Circular 260. Auburn, Alabama: Alabama Agricultural Experiment Station

[33] Hopkins AA, Young CA, Butler TJ, Bouton JH. Registration of 'Texoma' MaxQII tall fescue. Journal of Plant Registrations. 2010;5:14-18. DOI: 10.3198/jpr2010.02.0082crc

[34] Sleper DA, Mayland HF, Crawford RJ, Shewmaker GE, Massie MD. Registration of HiMag tall fescue germplasm. Crop Science. 2002;42:318-319. DOI: 10.2135/cropsci2002.3180 


\title{
Protein Supplementation Is Vital for Beef Cattle Fed with Tropical Pasture
}

\author{
Leilson R. Bezerra, Raimundo R. Ferreira, \\ Ricardo L. Edvan, Severino G. Neto, \\ Alex L. da Silva and Marcos J. de Araújo
}

Additional information is available at the end of the chapter

http://dx.doi.org/10.5772/intechopen.79813

\begin{abstract}
The production of beef on pasture is one of the potentials of Brazilian agriculture, mainly due to the territorial extension and climatic conditions. Therefore, the production of beef on tropical pastures mainly consists of the use of tropical forages; when correctly handled, forage plants show good productivity and improvement in the nutritive value. Among main factors that affect the performance of beef cattle fed on pastures, the availability and quality of the pasture stand first. In tropical regions, during the dry period of the year, the production of forage as well as its nutritive value is diminished. Hence, it is necessary to use protein supplements as a feed strategy to promote increased intake and improved nutrient utilization efficiency by animals. In view of this, by-products of biodiesel from oilseeds, such as peanuts, cottonseed and sunflower seeds, with high nutritional values can be used as an animal feed alternative to the protein sources commonly used for the formulation of supplements. Protein supplementation contributes to an increase in live weight gain as well as improvement in ruminal microbiota activity and, consequently, potentiates nutrient utilization efficiency in beef cattle fed with tropical pasture.
\end{abstract}

Keywords: ammonia, beef, biodiesel by-products, crude protein, grasses, supplement

\section{Introduction}

The production of beef on pasture is one of the potentials of Brazilian agriculture, mainly due to the territorial extension and its soil and climatic conditions, which are favorable for the cultivation and establishment of tropical pastures of high nutritional value offered to feed ruminant 
animals. However, in the transition period from the rainy season to the dry season, which marks the seasonality in forage production, the performance of tropical pastures declines in leaf/stem ratio, reduces in crude protein $(\mathrm{CP})$ content and increases in the proportion of dead material which makes them less palatable by animals due to low nutritional value [1].

Thus, in order to fill a gap resulting from the quantitative and qualitative production of tropical forage, supplementation with protein concentrates emerge as the main alternative in the supply of nutrients for the maintenance and maximization of the production of beef cattle in this productive system, which has as feed base, tropical grasses [2].

The potential of utilization of this feed strategy is evident, since animals supplemented with concentrates, regardless of the feeding strategy, demonstrate greater microbial efficiency when compared to the animals fed just pasture [3]. Corroborating with this work, another study was carried out by Batista and colleagues [4] to test whether a protein supplementation of beef cattle fed with tropical low quality pasture improves the efficiency of the use of nitrogen. Finally, concluding that the supplementation with proteins source with a higher proportion of degraded proteins in rumen favors the recycling of nitrogen and promotes increase in the synthesis of the microbial protein.

As a result of the growing world demand for biofuels, the biodiesel production chain uses oilseeds as raw material for the production of by-products and residues that, due to their nutritional value, have potential for use in animal nutrition, being characterized as protein and energy supplements. Thus, with a view to reducing the impact of the seasonality of forage production on pasture-based meat production systems, increasing the quantity and quality of nutrients and, consequently, maximizing the efficiency of their use, the practice of supplementing together with potential using of by-products from the biodiesel industry emerges as a strategy to increase the production of beef cattle to pasture.

\section{Production of beef in tropical pasture}

In beef cattle improvement, although the frequent use of confined production systems is very evident, pasture systems have been gaining prominence in their use due to lower feed costs and high response in animal performance (e.g., daily average gain and gain per area), resulting in higher profit margins.

The production of beef in tropical pastures consists mainly of the use of tropical forages. When properly managed, forage plants show high productivity, improvement in nutritional value and nutrient digestibility. In this case, the forage potential of tropical grasses on animal response was investigated by Maciel and colleagues [5] using three guandu grass cultivars (Massai, Tamani and Zuri) in the live weight gain of Nellore steers. The results showed that using grazing the average daily weight gain of cattle were $0.716,0.791$ and $0.883 \mathrm{~kg} / \mathrm{animal} /$ day for grass cultivars Massai, Tamani and Zuri, respectively.

The use of forage plants of tropical climate to compose a system of production of beef cattle occurs mainly due to its productive potential ( $\mathrm{kg} \mathrm{DM} / \mathrm{ha})$ and its anatomical and physiological characteristics, which are determinant in the choice as much as adoption of the type of pasture management. 
Tropical forage plants are grouped metabolically under C4, which possess greater advantage in the productive aspect, with morphological, anatomical and physiological characteristics that contribute to greater forage production per unit area compared to those in the temperate which are dominantly C3. Due to this, the characteristic of C4 tropical grasses becomes advantageous for breeding of bovines as it favors animal productivity by unit area, which can also increase the number of animals within the system.

In this context, De Araújo and colleagues [6] evaluated animal performance in a tropical pasture system with or without supplementation. This study showed that the Mombaça grass with $45 \mathrm{~cm}$ height at the end of the rainy season retains sufficient forage mass to maintain throughout the dry period, approximately 1.4 AU/ha, and moderate nutritive value (mean $8.1 \% \mathrm{CP}$ and $55.3 \%$ organic matter digestibility in vitro) to promote small gains. In conclusion, the researchers observed that such responses of quantitative and qualitative adaptability in the period of seasonality of production of forage species demonstrate the aptitude of this species for its use in meat production systems in tropical pastures.

When researching on the agronomic and structural characteristics of the Massai grass under grazing of sheep supplemented during the dry season, Fernandes and colleagues [7] verified that forage mass production considered satisfactory for the dry period of the year, regardless of the type of supplementation and grazing cycles.

Another study on the inherent characteristics of the plant (e.g., canopy structure, nutritional value) showed that the performance of the livestock was influenced by the type of grass management [8]. In this case, the pasture of Panicum maximum cv. Mombaça, which was managed at a height of $50 \mathrm{~cm}$ instead of $30 \mathrm{~cm}$ after grazing, resulted in high average daily gain of cattle (795 vs. $590 \mathrm{~g} /$ day of live weight) and high animal production per unit area (917 vs. $794 \mathrm{~kg} /$ ha of live weight).

According to Hodgson and Maxwell [9], the pasture management factor is related to the balance between animal production, maintenance of the pasture aiming at achieving higher productivity, improvement in nutritional value and consequent increase in the utilization efficiency of the accumulated forage without initiating the processes of senescence.

In an experiment carried out with forage grass Digitaria umfolozi submitted to different defoliation frequencies, the importance of pasture management on the productive characteristics and morphogenic and nutritional value was verified. Thus, in this study, it was found that the higher defoliation frequencies positively favored increasing number of leaf blades, stems + sheaths and total DM, characterizing this tropical forage with good potential for animal production [10]. The findings showed that the defoliation frequencies promote the growth of new Digitaria umfolozi grass plants with high concentrations of $\mathrm{CP}$ in leaf blades and stems + sheaths, indicating the need to identify appropriate management practices to efficiently harness the forage potential.

Production of meat in pasture refers to the dynamics between availability and the efficient use of forage. This is, animal production as a result of processes of soil-plant-animal interaction. Therefore, to achieve success using this production system, it is necessary to understand the importance and how these processes work until production is reached. According to Hodgson [11], animal production in pasture can be structured in three processes: Growth, Utilization and Conversion (Figure 1). 


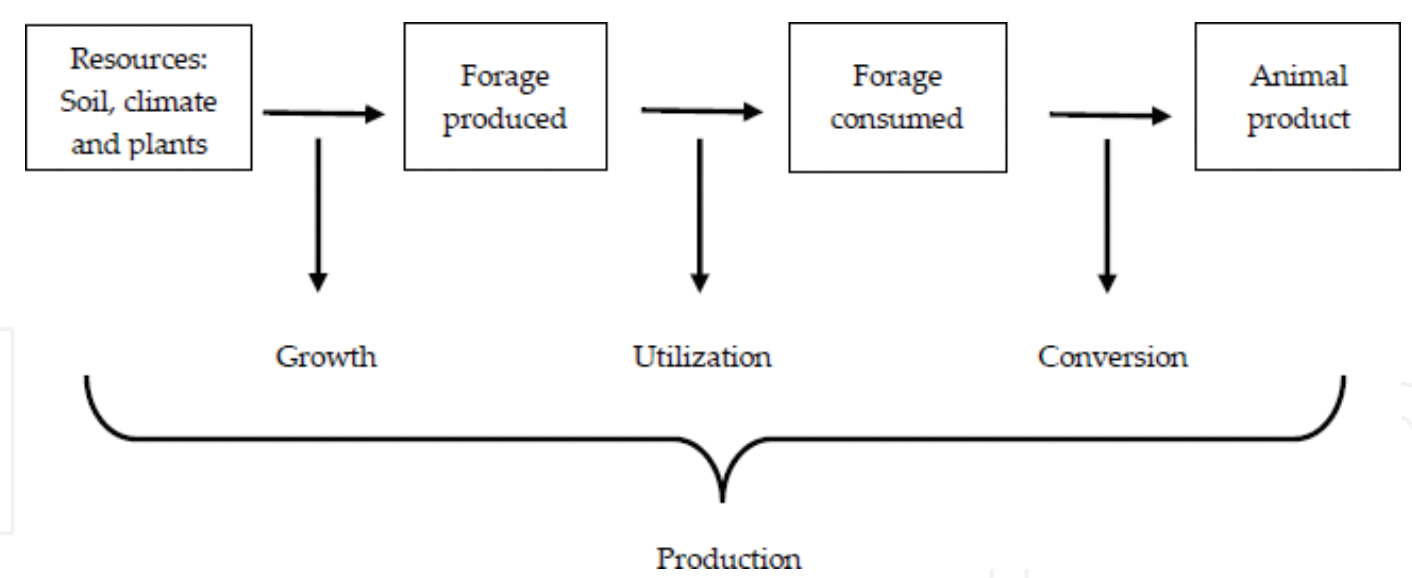

Figure 1. Schematic representation of animal production on pasture. Adapted from Hodgson [11].

At the stage of growth, the importance of natural and environmental resources in the development of the plant is observed, where fertile soil corrected for acidity and fertilization, presenting the availability of essential nutrients which together with climatic conditions (e.g., solar radiation, rainfall) favor the growth of the forage plant with greater vigor.

In the next step, which concerns the utilization, the forage produced under favorable climatic conditions will be in full qualitative force and available in the production system for the management of the pasture in which it will aim to improve and provide a greater "harvest" of the forage by animals.

Conversion, the last step, is the use of the forage consumed, that is, the ingestion of the forage is related to the efficiency of the use of the nutrients in the transformation to products of animal origin (e.g., beef).

Among major factors affecting the performance of beef cattle fed on pastures, the availability and quality of the pasture stand first. The involvement of meat production in pasture in tropical regions is related to the dry period of the year, in which there is a decrease in forage production and a reduction in nutritive value due to the elongation of the stems, increase in the fibrous fraction and decline in the crude protein of the plant. In this context, the study in the Brazilian savannas carried out by Maciel and colleagues [5] to investigate the effect of Guinean grass pastures on the seasonal live weight gain of beef cattle indicated a reduction in average daily gain (ADG) $(0.284 \mathrm{~kg} / \mathrm{head} /$ day $)$ of Nellore bulls in the dry season. This demonstrates that the seasonality in forage production directly reflects the performance of the animals.

Thus, the use of feed strategies (e.g., concentrated, roughage supplementation) that seek to complement and contribute to the maintenance and increase of meat production in tropical pasture is of great importance for the successful use of the tropical pasture production system.

\section{Protein supplementation for beef cattle in tropical pasture}

Protein supplementation for beef cattle in tropical pastures is due to the need to supplement the nutrients provided by forage, which is the main source of feed in this production system. 
Therefore, this feed strategy is necessary, mainly in the seasonality of the forage production, in which the tropical forage plants show a decline in the production, resulting in less availability of forage mass and elongation of the stems, negatively affecting leaf/stem ratio and consequent reduction of nutritional value.

The use of this feeding strategy in grazing livestock systems is an activity that can be applied to pasture management to increase support capacity as well as animal performance [12]. However, the efficiency of the use of protein supplements for beef cattle in pasture systems needs to increase the nutrient intake and to promote the improvement in the efficiency of using scarce resources in order to maximize the production of weight gain by the animals.

The study using different concentrations of protein supplementation on the nutritional and productive performance characteristics of grazing heifers during the rainy, dry and tropical dry seasons carried out by Cabral and colleagues [12] indicated that a maximum gain of $489.4 \mathrm{~g} / \mathrm{kg}$ body weight was obtained from $1.05 \mathrm{~kg}$ of protein supplement, which is equivalent to a $32 \%$ increase in average daily gain over those receiving only mineral supplement.

According to Brandão et al. [1], the practice of supplementation of cattle in tropical pastures provides benefits to the ruminal microorganisms since it generates substrates for the development of microorganisms, which in turn improves the digestibility of fibrous feeds and consequently increases the consumption of the forage. Sampaio et al. [13] investigated the consumption and digestibility of beef cattle fed with low-quality tropical forage supplemented with nitrogen compounds. According to their findings, concentrations of 5 and $10 \mathrm{mg} / \mathrm{dL}$ of ammoniacal nitrogen provided nitrogen substrates (e.g., ammonia, amino acids) sufficient to maintain the microbial activity in the rumen and improved voluntary intake.

In evaluating the performance and efficiency of nitrogen utilization in cattle fed pasture of tropical grasses with supplementation, Detmann and colleagues [14] showed that nitrogen supplementation enhanced forage intake and nitrogen utilization, which as a consequence improved digestibility. According to this work, the highest benefit of supplementation was observed in the efficiency of nitrogen metabolism in the animal.

The most limiting factor for achieving greater efficiency with protein supplementation is the balance between protein and energy. Protein supplied via supplement is rapidly degraded upon reaching the rumen, hence readily available to microorganisms. Hence, it is necessary to keep the balance between the protein and the energy of the feed.

As a base feed of the pasture system, forage plants when in the rainy season and well managed provide forage of good nutritional value and good digestibility which contribute to a better balance between the protein of the supplement and grass energy. However, in the dry season, tropical forages are markedly affected in the total production and proportion of morphological components (e.g., leaf/stem ratio), in proportion of fibrous fraction, nutritive value, which alters the balance between protein and energy.

Several studies showed the benefits of protein supplementation for beef cattle in tropical pasture systems. However, crude protein concentrations should be adjusted according to the nutritional requirements of the animals. This is important since supplements with high concentrations of crude protein in the diet formulation of animals can generate excess nitrogen 
in the animal metabolism which is directed to the liver for urea synthesis and subsequent excretion via feces and urine. Thus, in addition to the energy expenditure in the metabolism and conversion of nitrogen to urea, this metabolite is excreted to the environment causing a negative impact on the natural resources (e.g., groundwater).

Another study Ankole $\times$ Friesian crossbred steers carried out by Asizua and colleagues [15] supported the findings indicated above. These studies, therefore, strongly suggested to carefully adjust the amount of fermentative supplements of carbohydrates and proteins and monitor their influence on the dynamics of the ruminal environment.

\section{Use of biodiesel by-products in the supplementation of beef cattle in tropical pasture}

The use of biodiesel by-products in the supplementation of beef cattle on tropical pasture is an emerging trend within production systems, in which, although tropical pastures are considered as primary source of feed for ruminant animals raised on pasture, the production of animal products (e.g., meat, milk) in these systems today require an increase in the use of agro-industrial by-products and agricultural residues as an alternative way of providing nutrients for economic optimization [15].

In pasture production systems, the supplementation provided for beef cattle is generally formulated with traditional protein sources (e.g., soybean meal). However, by-products resulting from the biodiesel process of oilseeds, such as peanuts, cottonseed and sunflower seeds, have high nutritional values and hence can be used as animal feed as an alternative to the protein and energy sources commonly used in the formulation of supplements.

Table 1 presents the composition of different supplementary sources generated from the biodiesel production chain in terms of dry matter (DM), ash, crude protein $(\mathrm{CP})$ and other key nutritive elements. Neto et al. [16] indicated that using these products instead of conventional ingredients the cost of feeding is saved, without compromising nutritional quality and the efficiency of the beef production.

Based on the study on heifers fed on tropical grass and supplemented with glycerin, Silva and colleagues [17] concluded that the use of biodiesel by-products up to $14.3 \%$, equivalent to $50.5 \%$ substitution of the energy, did not alter the centesimal composition of the meat. However, these supplements improved the fatty acid profile of the longissimus lumborum muscle and therefore increased the quality of the meat, with benefits for human health.

In response to the effect of replacing soybean meal with cottonseed on supplements containing $15 \%$ and $30 \% \mathrm{CP}$, as well as evaluating the effect of supplementation on the performance and nutritional status of Nellore heifers, it was evident that supplementation with cottonseed meal containing 30\% CP promoted greater DM digestibility when compared to the supplement containing only $15 \% \mathrm{CP}$. Based on this, the authors stated that cotton meal can totally replace soybean meal during the rainy season [18]. 


\begin{tabular}{lllll}
\hline Nutrients & \multicolumn{2}{l}{ By-products of biodiesel, g/kg } & & \\
\cline { 2 - 5 } & Soybean meal & Groundnut cake & Sunflower cake & Palm kernel cake \\
\hline Dry matter & 958 & 958 & 972 & 966 \\
Ash & 59.8 & 47.5 & 54.5 & 55.8 \\
Crude protein & 467 & 44.5 & 24.3 & 13.1 \\
Ether extract & 22.2 & 81.2 & 58.0 & 112 \\
Neutral detergent fiber & 105 & 143 & 339 & 696 \\
\hline Acid detergent fiber & 95.0 & 123 & 272 & 401 \\
Non-fibrous carbohydrates & 346 & 283 & 305 & 4.60 \\
Hemicellulose & 9.90 & 20.0 & 66.4 & 295 \\
Acid detergent lignin & 34.8 & 56.1 & 135 & 289 \\
Total carbohydrates & 451 & 426 & 644 & 701 \\
\hline
\end{tabular}

Adapted from Neto et al. [16].

Table 1. Composition of biodiesel by-products used in ruminant animal production systems.

Another study by Trung et al. [19] investigated the effect of different concentrations of cassava root meal supplementation peanut butter on the intake and performance of beef cattle. The study concluded that the combination of $1000 \mathrm{~g}$ of cassava root meal with $700 \mathrm{~g}$ of peanut cake significantly increased live weight gain with a tendency to improve feed intake and digestibility of organic matter (OM), reducing feed conversion and the cost of the ration.

\section{Performance of beef cattle fed tropical pasture supplemented with crude protein}

In investigating the use of supplements with different concentrations of crude protein for beef cattle in tropical pasture, Da Silva-Marques et al. [20] found that the supplement with higher crude protein content $(601 \mathrm{~g} / \mathrm{kg}$ of $\mathrm{CP}$ based on DM) promoted higher metabolism and efficiency of nitrogen, improving the nutritional parameters of beef cattle during grazing in the rainy season. Another study which evaluated the frequency of protein-energy supplementation and mineral supplementation of Nellore bulls in Marandu grass pasture showed an increase in DM, CP and higher digestibility of $\mathrm{CP}$ and NDF of pasture for animals receiving protein-energetic supplement five times a day [21].

Similarly, Neves and colleagues [22] investigated the effect of increasing concentrations of concentrated supplementation on intake, nutrient digestibility and performance of crossbred steers during the dry period of the year. Based on the findings, the authors recommended protein supplementation of $0.5 \%$ body weight (BW) with $24 \%$ CP to obtain gains of up to $0.500 \mathrm{~kg} /$ day for steers in pasture systems during the post-weaning phase in the dry season of the year. 
Similar study evaluated the effect of different protein concentrations on performance and metabolism of Nellore cattle in tropical pasture during the transition period from dry season to the rainy season [23]. The results showed that the response to supplementation is related to forage plant characteristics (e.g., forage canopy), resulting in benefits only at the early stage of the transition period from dry to rainy season.

\section{Conclusions}

Protein supplementation to grasses increases the live weight gain and the ruminal microbiota activity of beef cattle, which consequently potentiating the nutrient utilization in beef cattle fed with tropical pasture. Studies also showed that by-products of biodiesel can be used as alternative sources of protein to improve beef supplementation in tropical regions.

\section{Conflict of interest}

The authors declare that there is no conflict of interest.

\section{Author details}

Leilson R. Bezerra ${ }^{1}$, Raimundo R. Ferreira2*, Ricardo L. Edvan ${ }^{3}$, Severino G. Neto ${ }^{2}$, Alex L. da Silva ${ }^{2}$ and Marcos J. de Araújo ${ }^{3}$

*Address all correspondence to: agroloiola@hotmail.com

1 Department of Animal Science, Federal University of Campina Grande, Paraíba, Brazil

2 Department of Animal Science, Federal University of Paraiba, Paraíba, Brazil

3 Department of Animal Science, Federal University of Piauí, Piauí, Brazil

\section{References}

[1] Brandão RK, de Carvalho GG, Silva RR, Dias DL, Mendes FB, Lins TODA, Pereira MMS, Guimarães JO, Tosto MSL, Rufino LMA, de Araújo MLGML. Correlation between production performance and feeding behavior of steers on pasture during the rainy-dry transition period. Tropical Animal Health and Production. 2018;50(1):105-111. DOI: 10.1007/s11250-017-1408-3

[2] Assad LVF, Zervoudakis JT, Cabral LS, Hatamoto-Zervoudakis LK, Da Silva-Marques RP, Koscheck JFW, Toledo ÉR, Micheletti MV. Proteína degradável no rúmen e frequência 
de suplementação para novilhos Nelore em pastejo: Desempenho produtivo e análise econômica. Semina: Ciências Agrárias. 2015;36(1):2119-2130. DOI: 10.5433/1679-0359. 2015v36n3Supl1p2119

[3] Rocha TC, de Alencar Fontes CA, da Silva RTS, Processi EF, do Valle FRAF, Lombardi CT, Oliveira RL, Bezerra LR. Performance, nitrogen balance and microbial efficiency of beef cattle under concentrate supplementation strategies in intensive management of a tropical pasture. Tropical Animal Health and Production. 2016;48(3):673-681

[4] Batista ED, Detmann E, Titgemeyer EC, Valadares Filho SC, Valadares RFD, Prates LL, Rennó LN, Paulino MF. Effects of varying ruminally undegradable protein supplementation on forage digestion, nitrogen metabolism, and urea kinetics in Nellore cattle fed low-quality tropical forage. Journal of Animal Science. 2016;94(1):201-216. DOI: 10.2527/ jas2015-9493

[5] Maciel GA, Braga GJ, Guimarães R, Ramos AKB, Carvalho MA, Fernandes FD, Fonseca CEL, Jank L. Seasonal liveweight gain of beef cattle on guineagrass pastures in the Brazilian cerrados. Agronomy Journal. 2018;110:480-487. DOI: 10.2134/agronj2017.05.0262

[6] De Araújo IMM, dos Santos Difante G, Euclides VPB, Montagner DB, da Costa Gomes R. Animal performance with and without supplements in Mombaça guinea grass pastures during dry season. Journal of Agricultural Science. 2017;9(7):145. DOI: 10.5539/jas. v9n7p145

[7] Fernandes LS, Difante GDS, Montagner DB, Emerenciano Neto JV, Araújo IMM, Campos NRF. Structure of massai grass pasture grazed on by sheep supplemented in the dry season. Grassland Science. 2017;63(3):177-183. DOI: 10.1111/grs.12165

[8] Euclides VPB, Carpejani GC, Montagner DB, Nascimento Junior D, Barbosa RA, Difante GS. Maintaining post-grazing sward height of Panicum maximum (cv. Mombaça) at $50 \mathrm{~cm}$ led to higher animal performance compared with post-grazing height of $30 \mathrm{~cm}$. Grass and Forage Science. 2018;73(1):174-182. DOI: 10.1111/gfs.12292

[9] Hodgson J, Maxwell TJ. Grazing research and grazing management. In: Hill Farming Research Organisation, Biennial Report. Penicuik, Midlothian, UK; 1981. pp. 169-187

[10] Araújo HR, de Albuquerque Rangel JH, Fagundes JL, Muniz EN, de Oliveira Santos D, Neto JAS, Castro Filho ES, de Arruda Santos GR. Productive characteristics of the grass Digitaria umfolozi subjected to defoliation frequencies. Semina: Ciências Agrárias. 2017;38(1):343-354. DOI: 10.5433/1679-0359.2017v38n1p343

[11] Hodgson J. Grazing Management: Science into Practice. London: Longman Scientific and Technical; 1990. $203 \mathrm{p}$

[12] Cabral CHA, Paulino MF, Detmann E, de Campos Valadares Filho S, de Barros LV, Valente ÉEL, Bauer MO, Cabral CEA. Levels of supplementation for grazing beef heifers. Asian-Australasian Journal of Animal Sciences. 2014;27(6):806. DOI: 10.5713/ ajas.2013.13542 
[13] Sampaio CB, Detmann E, Paulino MF, Valadares Filho SC, de Souza MA, Lazzarini I, Paulino PVR, de Queiroz AC. Intake and digestibility in cattle fed low-quality tropical forage and supplemented with nitrogenous compounds. Tropical Animal Health and Production. 2010;42(7):1471-1479. DOI: 10.1007/s11250-010-9581-7

[14] Detmann E, Valente ÉEL, Batista ED, Huhtanen P. An evaluation of the performance and efficiency of nitrogen utilization in cattle fed tropical grass pastures with supplementation. Livestock Science. 2014;162:141-153. DOI: 10.1016/j.livsci.2014.01.029

[15] Asizua D, Mpairwe D, Kabi F, Mutetikka D, Bareeba FB, Hvelplund T, Weisbjergc MR, Madsen J. Effects of feeding systems on rumen environment, degradability and passage kinetics in Ankole $\times$ Friesian crossbred steers. Livestock Science. 2018;210:47-54. DOI: 10.1016/j.livsci.2018.02.006

[16] Neto SG, Oliveira RL, de Lima FHS, de Medeiros AN, Bezerra LR, Viégas J, do Nascimento Júnior NG, de Freitas Neto MD. Milk production, intake, digestion, blood parameters, and ingestive behavior of cows supplemented with by-products from the biodiesel industry. Tropical Animal Health and Production. 2015;47(1):191-200. DOI: 10.1007/ s11250-014-0706-2

[17] Silva RR, Facuri LMAM, de Carvalho GGP, da Silva FF, Simionato JI, Sampaio CB, et al. Meat quality of heifers finished on pasture with tropical grass and supplemented with glycerin. Ciencia e Investigación Agraria. 2017;44(3):320-332. DOI: 10.7764/rcia. v44i3.1861

[18] Martins LS, Paulino MF, Marcondes MI, Rennó LN, de Almeida DM, Lopes SA, Marquez DEC, Manso MR, da Silva AG, Valente ÉEL. Cottonseed meal is a suitable replacement for soybean meal in supplements fed to Nellore heifers grazing Brachiaria decumbens. Animal Production Science. 2017;57(9):1893-1898. DOI: 10.1071/AN15709

[19] Trung NT, Berg J, Cuong VC, Kjos NP. Influence of varying levels of supplemental cassava root meal without or with groundnut cake on performance of growing Laisind cattle. Tropical Animal Health and Production. 2014;46(6):925-930. DOI: 10.1007/s11250014-0586-5

[20] Da Silva-Marques RP, Zervoudakis JT, Hatamoto-Zervoudakis LK, Da Rosa PIJL, Do Nascimento Matos NB, Feliciano AL, Da Silva Cabral L. Efficiency of nitrogen metabolism in beef cattle grazing pasture and supplemented with different protein levels in the rainy season. Tropical Animal Health and Production. 2018;50(4):715-720. DOI: 10.1007/ s11250-017-1485-3

[21] Da Silva-Marques RP, Zervoudakis JT, De Paula NF, Hatamoto-Zervoudakis LK, Silva PIJLR, Matos NBN. Effects of protein-energetic supplementation frequency on growth performance and nutritional characteristics of grazing beef cattle. Tropical Animal Health and Production. 2018;50(3):495-501. DOI: 10.1007/s11250-017-1458-6 
[22] Neves DSB, Silva RR, da Silva FF, Santos LV, Abreu Filh G, de Souza SO, et al.. Increasing levels of supplementation for crossbred steers on pasture during the dry period of the year. Tropical Animal Health and Production. 2018:1-6. DOI: 10.1007/s11250-018-1574-y

[23] Fernandes RM, De Almeida CM, Carvalho BC, Neto JAA, Mota VAC, De Resende FD, Siqueira GR. Effect of supplementation of beef cattle with different protein levels and degradation rates during transition from the dry to rainy season. Tropical Animal Health and Production. 2016;48(1):95-101. DOI: 10.1007/s11250-015-0925-1 

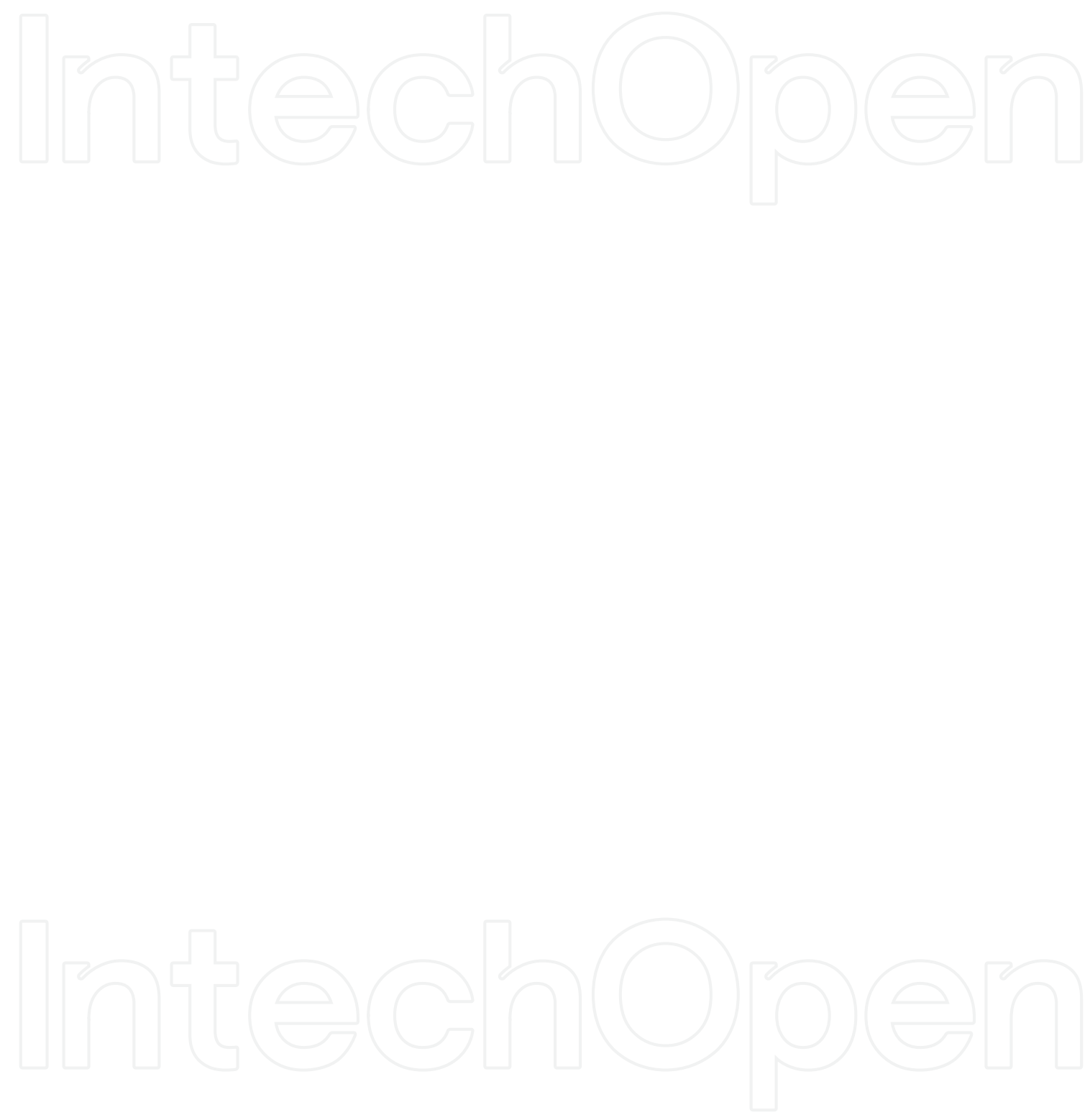


\title{
Planting Geometry and Herbicides for Weed Control in Rice: Implications and Challenges
}

\author{
Umair Ashraf, Saddam Hussain, Alam Sher, \\ Muhammad Abrar, Imran Khan and \\ Shakeel A. Anjum
}

Additional information is available at the end of the chapter

http://dx.doi.org/10.5772/intechopen.79579

\begin{abstract}
Weeds are one of the major biological threats to higher rice productivity worldwide. Various cultural, biological, physical and chemical practices affect the composition and intensity of weeds in rice fields. Generally, weeds can be controlled through herbicides; nevertheless, chemical weed control is not a sustainable option on a long term. Various agronomic practices such as the use of tolerant cultivars, adjusting sowing time, tillage permutations and plant geometry may reduce the weed pressure in rice. Integrated approaches for weed management, emphasizing on the combination of management practices and scientific knowledge, may reduce the economic costs and improve weed control owing to the complexity of the weed community. The present chapter reveals the role of planting geometry and herbicides as weed management strategies in rice, and discusses the issue of herbicide resistance associated with chemical weed control. Moreover, the research and knowledge gaps in rice weed management through planting geometry and herbicides were also highlighted.
\end{abstract}

Keywords: rice, planting geometry, herbicidal sprays, weed management, yield

\section{Introduction}

To declare a plant as a weed means to narrate it with the human environment. Their presence in crops, pastures, lawns, gardens, rangelands, along roads or thoroughfares, parks, recreational areas and other natural lands, interferes with human intensions by changing the native flora/natural vegetation of a region. Hence, human intentions are directly linked 
to define a weed and their activities endorse weed establishment and dissemination while weed persistence over a period, its type and density, emergence time and its interference period with the crop are directly related to the weed-related losses in crop yields [1]. Both ecological and biological factors of a specific region affect weed composition, distribution and propagation as well as its diversification and occupancy in that region. Interference to the environment often led to multiplication and colonization of plants in open space whose biological activities predispose them. Most of the weed species in annual cropping systems are those which rapidly colonized under disturbed environment [2]. Weed interference and species composition of an area are affected by various environmental and biological factors like soil type, soil moisture, $\mathrm{pH}$, light intensity, temperature, precipitation patterns, crop type, crop competitiveness, crop-weed interference and other flora and fauna of that area. Further, weed interference, its competitive ability and population dynamics changes with weed species composition which further affected by human efforts to control them.

Weeds being the most serious pests in agriculture have the ability to compete with the crop for nutrients through rapid growth and development. Competitive abilities of weeds developed through natural selection make them more vigorous even under severe conditions [3]. Weeds uptake available nutrients and compete with rice plants for water, light and space. Weeds under adverse conditions negatively affect plant growth cycle, plant developmental pattern, leaf architecture, tillering ability, as well as yield and yield attributes of rice [4]. Out of the other factors, poor weed management is also responsible for reduction in rice yield depending on weed type and their infestation [5]. Further, weed management in rice is one of the major causes that affect its crop yield. Normally the decrease in yield due to weeds ranges between 15 and $20 \%$, however; under severe conditions the losses may raise up to $50 \%$ or more depending upon the weeds species, types, pressure and intensity [3]. For example, up to $76 \%$ reduction in rice grown under puddle conditions is caused due to uncontrolled weeds [6]. The most problematic and common weeds in rice especially in Asia are Cyperus iria, Cyperus maritimus, Echinochloa glabrescens, Cyperus rotundus, Cyperus difformis, Paspalum distichum, Echinochloa colona, Echinochloa crus-galli, and Marsilea minuta [7-9].

Weed control in rice crop is always remaining a difficult task for successful crop production as their presence in the field cause severe reduction in yield and quality of crops and increase the cost of production [10]. The use of herbicides to control weeds is just in the introductory stage in most of the developing and under developed countries and farmers of these regions also behave rationally in herbicide usage. Among all the weed control methods, chemical weed control is commonly used to overcome weeds infestation which is easy, quick, time saving, cost effective and the most reliable method to control weeds in rice. There are diverse weed communities and types in rice fields. Hence the use of a single herbicide cannot give satisfactory and cost-effective results of weed control [11]. The use of herbicides gives effective control of weeds; hence care must be taken in the selection of herbicide that should be based on the target weed species in addition to their broader category of grass, sedge and broadleaf for planning of an effective weed control program for successful rice production [12]. No doubt, manual weed control is efficient method to control weeds but difficult to apply due to scarcity and rising wages of labor and its dependence on the prevailing weather conditions [13]. Azmi et al. [14] stated that use of herbicides seems a crucial part to control and manage weed infestation in rice. An effective and feasible weed management program is essential to overcome various 
types of weeds throughout the growing period of crop as manual control of weeds is not a quick method. It requires lot of time and labor as well whilst herbicides offer easy, economical and quick control of weeds if applied in proper dose and at a proper stage of the crop [15].

Not only the weeds pressure, but also the sub-optimal plant population also favors weeds to grow profusely which can be managed by spatial arrangement of crops [4]. The growth, development and the yield of rice as well as the intensity of weed infestation are greatly affected by plant spacing. Planting density in rice strongly influences the growth and development due to its inter-specific competition which affects grain yield [16]. Dense plant population may lead to intra-plant competition whereas lower plant population provides the space for off-types to grow easily [17]. Hossain et al. [18] reported that in too dense populated rice fields, interspecific competition starts which may cause lodging and gradual shading and results in yield penalty. Hence, it is necessary to adjust suitable plant spacing and plant population as a weed management tool and to get better economic returns.

Integrated weed management is the best option to control weeds whereas cultural weed control is a key component of it $[19,20]$. By manipulating the different weed management strategies, the competitive ability of crop over weeds for above and below ground resources can be enhanced [20-24]. This review comprehends the role of planting geometry and herbicide application as a viable tool for weed management in rice.

\section{Weed dynamics and control in rice}

Weeds are serious problem to rice production. It accounts for one third of the total crop yield losses due to various biotic factors. Simply, plants that compete and interfere with the desirable crop plants and compete with its growth and development are known as weeds [25]. Weeds are one of the main factors which are responsible for low production of field crops [26-28]. Weeds compete with crops for available resources like light, space, water as well as nutrients. During early growth stages weeds compete with crop plants vigorously than later growth stages and ultimately cause substantial reduction in growth and yield [29]. For instance, $16-48 \%$ grain yield of transplanted rice is reduced due to the occurrence of weed flora in rice field [4]. This weed infestation in rice disturbs the rice growth badly and may result in complete crop failure [30]. So to minimize the weed density, various weed control strategies have been evaluated in rice crop to get maximum output [20,30]. Moreover, weed competition is more severe in direct seeded than in transplanted rice [13, 31-33]. Reduction in grain yield of direct seeded rice (DSR), wet seeded rice (WSR) and transplanted rice due to uncontrolled weeds was $75.8,70.6$ and $62.6 \%$ respectively [31]. Wet seeded rice refers to the use of pre-germinated seeds as a planting material.

There are about 50 weed species found in rice field causing severe losses in productivity all over the world [33]. Asian sprangletop (Leptochloa chinensis L.) and barnyard grass (Echinochloa crus-galli) quickly establish formal in a very short duration especially where rice is produced by direct seeding [34]. Echinochloa colona L., known as a Jungle rice, grows vigorously in direct seeded rice whilst predominantly found in both direct-seeded and transplanted rice $[13,35,36]$. 


\begin{tabular}{|c|c|c|c|}
\hline $\begin{array}{l}\text { Sr. } \\
\text { No. }\end{array}$ & Family & Category & Weed species \\
\hline 1 & Poaceae & Grass & $\begin{array}{l}\text { Paspalum distichum, Echinochloa colona, Leptochloa chinensis, Echinichloa } \\
\text { crus-galli, Oryza sativa (weedy rice), Digitaria setigera, Digitaria ciliaris, } \\
\text { Eleusine indica, Ischaemum rugosum, and Digitaria ciliaris }\end{array}$ \\
\hline 2 & Cyperaceae & Sedge & Cyperus rotundus, Fimbristy lismiliacea, Cyperus difformis, and Cyperusiria \\
\hline 3 & Commelinaceae & Broadleaved & Commelina benghalensis \\
\hline 4 & Pontederiaceae & & Monochoria vaginalis \\
\hline 5 & Asteraceae & & Eclipta prostrata \\
\hline 6 & Convolvulaceae & & Ipomoea aquatica \\
\hline 7 & Onagraceae & & Ludwigia octovalvis \\
\hline 8 & Sphenocleaceae & & Sphenoclea zeylanica \\
\hline 9 & Onagraceae & & Ludwigia adscendens \\
\hline
\end{tabular}

Source: [37]

Table 1. The most common weed species in rice.

Juraimi et al. [37] observed that dominance of weed species vary significantly with weed control and different crop establishment methods and reported that E. crus-galli and E. colona are the most problematic weeds found in rice. Moreover, in the upland rice field, Cynodon dactylon and Cyperus rotundus are also serious weeds of rice. The list of most common weeds infesting rice fields are presented in Table 1.

Singh et al. [38, 39] reported a reduction of $12-98 \%$ in rice yield due to weed infestation. Threshold levels of Cyperus iria and Echinochloa crus-galli were estimated about 30 and 20 plants $\mathrm{m}^{-2}$ in transplanted rice [40, 41]. A competition study of C. iria in transplanted rice showed that 30 days competition caused $12.9 \%$ while a 40 day competition caused $43.5 \%$ yield loss in rice [42]. Similarly, about $25 \mathrm{~kg} \mathrm{ha}^{-1}$ yield is reduced in direct seeded rice for every day delay in weeding [43]. According to the same study, 35.2\% yield reduction was recorded by delaying the removal $C$. iria for a period of 30-40 days after tillering. At the seedling stage, E. colona and E. crus-galli are closely related to rice plant and may be called as "crop mimicry" that need to control in time [44]. While checking the efficacy of different weed control strategies, Cherati et al. [45] found weed control through herbicides as the best method followed by mechanical weeding without engine, three hand weeding and power mechanical weeding. Chemical and manual weed control measures resulted in similar effect under puddled rice [46]. Anaya [47] and Remington and Posner [43] reported that lack of weed control in fields shared about $12 \%$ of total waste production and suggested hand weeding, chemical or mechanical weeding or their combinations for better weed control.

\section{Planting geometry: role in weed management and rice yield}

In most crops, narrower row spacing can increase the competitiveness of a crop [48] whilst reduced crop spacing has also been found to favor the crop development at the expense of weeds. 
Weeds are the serious pest in rice production but these can be managed effectively by maintaining the critical periods of weed competition [11] as growth of the rice is greatly influenced by all the competition periods [49]. Chemical weed control is the most popular weed control method, however herbicide resistance, limited amount of available herbicides, weed population shifts and expensive herbicide products may limit its application in the future [50,51]. To control weeds more effectively and to minimize the complete reliance on herbicides, adoption of cultural approaches in integrated pest management by farmers has been increasing [14].

Weeds can be suppressed by enhancing the crop competitive ability [52]. Hand weeding is a cultural approach to control weeds but it is a very tedious, labor intensive and slow method [53]. Weed control through herbicides is effective but total dependence on chemical weed control with extensive use of hazardous farm chemicals has necessitated the new approaches to tackle the weeds problems [54]. In addition, the use of herbicides on a large scale has resulted serious ecological threats such as shifts in weed population and dominance of minor weeds [55].

Both yield and yield components of rice are affected by plant spacings as well as planting density [56]. Optimum plant density is necessary to obtain higher yields in rice [57]. The effect of both varied planting patterns and herbicides on weed dynamics in rice is presented

a)

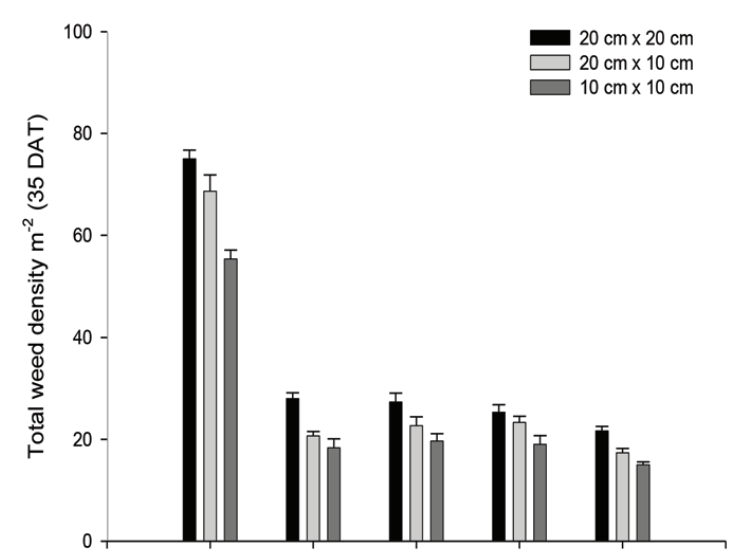

b)

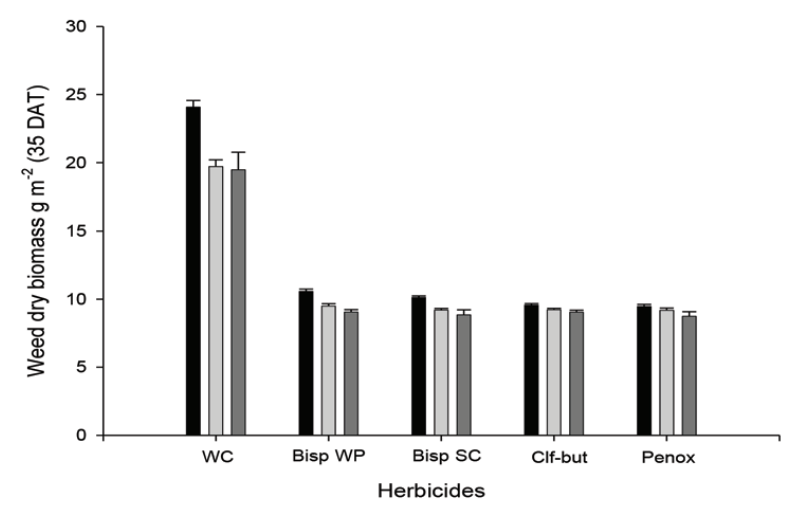

c)

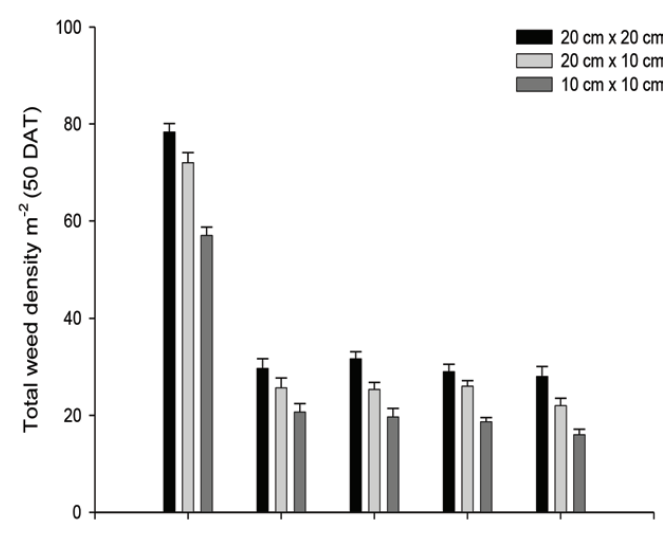

d)

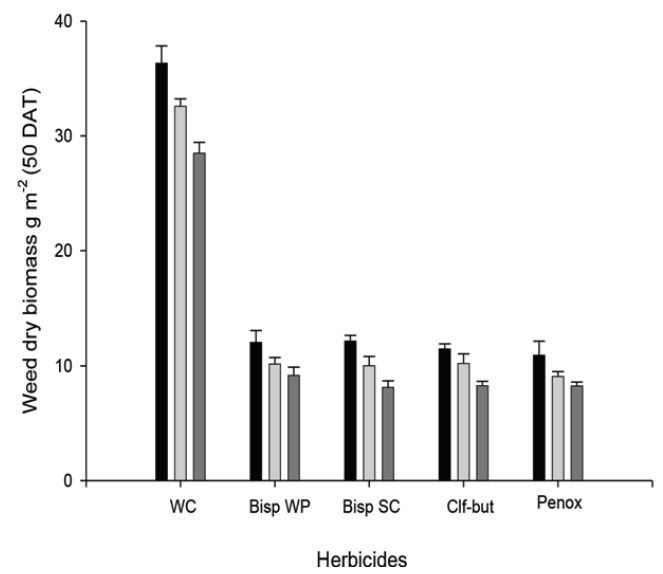

Figure 1. Effect of differnt planting patterns and early post emergence herbicides on total weed density, and weed dry biomass at 35 and 50 days after transplanting (DAT) (a-d). Bars above means represent S.E. of three replicates. WC: weedy check; Bisp WP: Bispyribac sodium 20\% WP at $39.50 \mathrm{~g}$ a.i. ha ${ }^{-1}$; Bisp SC: Bispyribac sodium $100 \mathrm{SC}$ at $39.50 \mathrm{~g}$ a.i. ha $^{-1}$; Clf-but: Cyhalofop-butyle 10\% EC at 49.50 g a.i. ha- ${ }^{-1}$; Penox: Penoxulam 240 EC at 15 g a.i. ha ${ }^{-1}$ [64]. 


\begin{tabular}{|c|c|c|c|c|}
\hline $\begin{array}{l}\text { Sr. } \\
\text { No. }\end{array}$ & $\begin{array}{l}\text { Rice } \\
\text { establishment } \\
\text { method }\end{array}$ & $\begin{array}{l}\text { Widest } \\
\text { spacing }\end{array}$ & $\begin{array}{l}\text { Narrowest } \\
\text { spacing }\end{array}$ & Remarks \\
\hline 1 & DSR & $20 \times 20 \mathrm{~cm}$ & $10 \times 10 \mathrm{~cm}$ & $\begin{array}{l}\text { Under weed free conditions, yield was } 29 \\
\text { higher in the plot with } 10 \mathrm{~cm} \text { row spacing } \\
\text { than } 20 \mathrm{~cm} \text { whereas grain yield } 87-88 \% \\
\text { higher than uncontrolled weedy plots. }\end{array}$ \\
\hline 2 & TR & $20 \times 20 \mathrm{~cm}$ & $15 \times 15 \mathrm{~cm}$ & $\begin{array}{l}24.31 \% \text { higher yield was recorded in wide } \\
\text { spacing of } 20 \times 20 \mathrm{~cm} \text { compared with } \\
\text { narrow spacing of } 15 \times 15 \mathrm{~cm} \text {. whilst } 36.63 \\
\text { increase in paddy yield was observed in } \\
\text { weed free treatment compared with weed } \\
\text { check. }\end{array}$ \\
\hline 3 & TR & $20 \times 10 \mathrm{~cm}$ & $30 \times 20 \mathrm{~cm}$ & $\begin{array}{l}\text { Among the spacing, the widest spacing } \\
\text { gave maximum weed control efficiency } \\
(55.30 \%) \text { at } 30 \text { DAT and lowest weed } \\
\text { control efficiency }(62.03 \%) \text { at } 60 \text { DAT. }\end{array}$ \\
\hline
\end{tabular}

TR $20 \times 10 \mathrm{~cm} \quad 20 \times 10 \mathrm{~cm}$

Adoption of $20 \times 10 \mathrm{~cm}$ spacing and pre emergence application of anilofos 2, 4-D at 6 days after transplanted supplemented with 2, 4-D Na salt at 20 days after transplanted generally enhanced rice yield from 58.13 to $70.41 \%$.

Rice spacing determines rice-weed competition and can play a decisive role to minimize weed pressure. Closer spacing could be considered as a vital tool in integrated weed management program for aerobic rice. 51.79 and $70.68 \%$ increase in weed dry biomass was observed for $10 \times 10 \mathrm{~cm}$ and $30 \times 30 \mathrm{~cm}$, respectively. Up to $50 \%$ increase in rice yield was recorded for narrow spacing compared with wide spacing

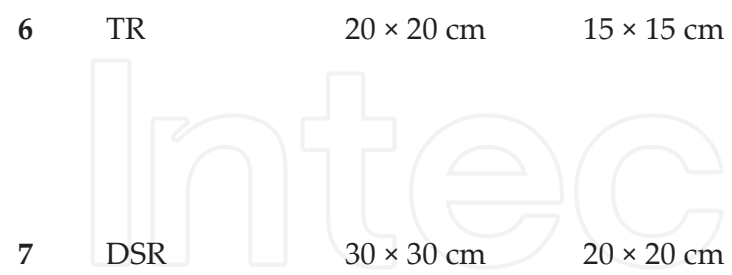

The maximum weed density and dry biomass was found in widest spacing, nevertheless, the yield was also remained higher in widest spacing with $19.55 \%$ more than the closest.

The weed population especially E. colona and E. crus-galli was $29 \%$ more in widely spaced crop than narrow spacing whilst 18.68 and $23.45 \%$ higher grain yield was recorded in narrowest spacing than wide spacing for E. colona and E. crus-galli, respectively.

DSR $30 \times 30 \mathrm{~cm} \quad 15 \times 15 \mathrm{~cm}$

Rice grown in $30 \mathrm{~cm}$ row spacing has

References

[3] less yield as compared with $15 \mathrm{~cm}$.

9 TR $25 \times 10 \mathrm{~cm} 20 \times 10 \mathrm{~cm}$

Short duration of 'aman' rice transplanted at $25 \times 15 \mathrm{~cm}$ with three hand weedings gives $193 \%$ total dry matter than $20 \times 10 \mathrm{~cm}$ with weedy control. 


\begin{tabular}{|c|c|c|c|c|c|}
\hline $\begin{array}{l}\text { Sr. } \\
\text { No. }\end{array}$ & $\begin{array}{l}\text { Rice } \\
\text { establishment } \\
\text { method }\end{array}$ & $\begin{array}{l}\text { Widest } \\
\text { spacing }\end{array}$ & $\begin{array}{l}\text { Narrowest } \\
\text { spacing }\end{array}$ & Remarks & References \\
\hline 10 & TR & $10 \times 10 \mathrm{~cm}$ & $10 \times 10 \mathrm{~cm}$ & $\begin{array}{l}\text { Grain yield was remained lower up to } 25 \% \\
\text { in narrowest plant spacing than widest } \\
\text { spacing. Lower grain yield could be due to } \\
\text { intra specific competition in rice. }\end{array}$ & {$[64]$} \\
\hline 11 & DSR \& TR & $25 \times 15 \mathrm{~cm}$ & $20 \times 10 \mathrm{~cm}$ & $\begin{array}{l}\text { Narrow row spacing in both DSR and TR } \\
\text { resulted in higher grain productivity from } \\
4.7 \text { to } 12.2 \% \text { with reduced weed density. }\end{array}$ & [65] \\
\hline 12 & SRI & $30 \times 30 \mathrm{~cm}$ & $25 \times 25 \mathrm{~cm}$ & $\begin{array}{l}\text { The rice yield in closer spacing was } 19.50 \% \\
\text { more than wider. Further, weed control } \\
\text { through anilophos at } 0.4 \mathrm{kh} \mathrm{ha}^{-1} \text { gave } \\
\text { higher yield than weedy check. }\end{array}$ & [66] \\
\hline
\end{tabular}

DSR: Direct seeded rice, TR: Transplanted rice, SRI: System of rice intensification

Table 2. Planting geometry-induced changes in weed density and yield of direct seeded and transplanted rice.

in Figure 1. According to Awan et al. [58], the yield of rice was much higher where nursery was transplanted in lines as compared to randomly transplanting. Bozorgi et al. [59] studied three levels of plant spacings i.e., $15 \times 15,20 \times 20$, and $25 \times 25 \mathrm{~cm}$ in interaction with number of seedlings per hill and found the highest grain yield from $15 \times 15 \mathrm{~cm}$. Furthermore, narrow plant spacing in rice significantly reduced weed pressure and weed dry biomass [60]. Hence, plant spacing in rice determines rice-weed competition and has a crucial role in reducing weed intensity and rice yield (Table 2). Among the three plant spacings $(20 \times 10,25 \times 15$, $30 \times 20 \mathrm{~cm}$ ), the efficiency of weed control was the highest $(62.03 \%)$ in $20 \times 10 \mathrm{~cm}$ at 30 days after transplanting (DAT), while the lowest (55.03\%) at 60 DAT [17]. Ehsanullah et al. [16] studied four rice sowing methods and concluded that the highest grain yield $\left(3.06 \mathrm{t} \mathrm{ha}^{-1}\right)$ was obtained from $20 \times 20 \mathrm{~cm}$ spacing while the lowest of $2.52 \mathrm{t} \mathrm{ha}^{-1}$ from direct seeding by broadcasting the seeds in the standing water. Rasool et al. [67] estimated the impacts of three plant spacings $(15 \times 15,15 \times 20,20 \times 20 \mathrm{~cm})$ on yield and yield components of rice and observed maximum plant height, total number of tillers, leaf area index (LAI) and total dry matter accumulation from $15 \times 15 \mathrm{~cm}$ which provided $8.97 \%$ higher yield than the $20 \times 20 \mathrm{~cm}$ spacing. Similarly higher grain yield was obtained in 50 hills $\mathrm{m}^{-2}$ and the paddy yield record obtained due to high planting density over 16.7, 22.2, 25 and 33.3 hills $\mathrm{m}^{-2}$ were $4.0,9.5,4.8$ and $6.0 \%$, respectively [68]. Moreover, number of panicle per plant and straw yield of rice increased significantly by raising planting density in rice [69]. Tari et al. [70] concluded that rice sown at the spacing of $20 \times 20 \mathrm{~cm}$ and the application fertilizer $\left(138 \mathrm{~kg} \mathrm{~N} \mathrm{ha}^{-1}\right)$ gave maximum yield. Out of three spacings investigated $(5 \times 15,15 \times 20$ and $15 \times 25 \mathrm{~cm})$, the highest yield and harvest index were recorded for rice from $15 \times 20 \mathrm{~cm}$ [71]. Sultana et al. [72] evaluated the effect of five hill to hill spacings viz. 2.5, 5, 10, 15 and $20 \mathrm{~cm}$ and two row spacings viz. 20 and $25 \mathrm{~cm}$ where the highest grain yield was recorded at $25 \times 15 \mathrm{~cm}$ and the lowest at $20 \times 2.5 \mathrm{~cm}$ spacing. Further studies using four row spacings $(10 \times 25,15 \times 25,20 \times 25$, and $25 \times 25 \mathrm{~cm})$ resulted in significant improvements in rice yield and related components from $15 \times 25 \mathrm{~cm}$ spacing with two seedlings per hill with four levels of seedlings per hill were assessed by Alam et al. [73]. In addition, vigorous growth and better yield of rice was harvested from the 
spacing of $22.5 \times 22.5 \mathrm{~cm}^{2}$ compared to that of $20 \times 20 \mathrm{~cm}^{2}$ and $25 \times 25 \mathrm{~cm}^{2}$ [74]. The yield of rice was found higher in widest plant spacing i.e., $20 \times 20 \mathrm{~cm}$ than the narrow plant spacings i.e., $20 \times 15 \mathrm{~cm}$ and $10 \times 10 \mathrm{~cm}$.

The performance of rice established under different planting geometries was investigated by Ashraf et al. [4] where a maximum yield of $5.87 \mathrm{t} \mathrm{ha}^{-1}$ was obtained using Machete 5G and GGR-6 under plant spacing $20 \times 20 \mathrm{~cm}$. Furthermore, Jacob et al. [75] concluded that $20 \times 10 \mathrm{~cm}$ spacing with the application of anilofos+2, 4-DEE (ready mix) $0.40+0.53 \mathrm{~kg} \mathrm{ha}^{-1}$ supplemented with 2, 4-D sodium salt $1 \mathrm{~kg} \mathrm{ha}^{-1}$ provided the maximum grain yield and minimum weed competition. Hence, spatial arrangement of crop plants is the best cultural practice to reduce weed competition and raise rice yield.

\section{Weed control in rice using herbicides}

Herbicides are chemicals that either kill or inhibit growth of plants. They can be classified in numerous ways viz; by crop (e.g., a soybean herbicide), by their application timing (e.g., pre- or post- emergence to the crop or weeds), by their chemical family (e.g., sulfonylureas, dinitroanilines), by their path of mobility in the plant (e.g., translocation by phloem, xylem, or both), and by their mode of action (MOA) (e.g., photosystem II inhibitors, ALS inhibitors). In the context of herbicide resistance in crops and weeds, MOA is the most relevant classifier because it best describes the means by which the herbicide imposes selection pressure on weeds, and its manipulation can be used for herbicide resistant weed management. More than 200 active ingredients are registered as herbicides around the world, and this estimate does not include compounds that are used exclusively as crop growth regulators or crop desiccants. There are, however, only 29 major mechanisms of herbicide action, including a group of herbicides for which the MOA is unknown [76]. The herbicides are very specific for their mode of action and differ in their weed control efficacy (Table 3).

Chemical weed control is becoming priority for farmers due to mainly shortage of labor for hand weeding [77]. Rising wages of labor and their non-availability at peak time discourage hand weeding and make it necessary to use alternative methods of weed control including herbicides [13, 33, 78]. Hence, the importance of herbicides cannot be ignored as it is the most effective, time saving and reliable weed control technology available today [79]. Weedicides can suppress weeds effectively and may provide a weed free environment if applied at proper stage and time [80]. Chemical weed control has an edge over cultural weed control as it is quick, cost effective and saves labor, time and money. So, it may be regarded as an economical method of weed control [81].

The doses of registered herbicides under changing weed composition and density as well as different growth stages may be overestimated to get maximum weed control [82]. Manufacturers recommend higher doses of herbicides than the optimum dose which controls the weed population at satisfactory level [83]. The rate of herbicide to be applied depends on the type of weed flora, the density of weed population, phenological development of both the weed and the crops and the prevailing environmental conditions of the location. Keeping the 


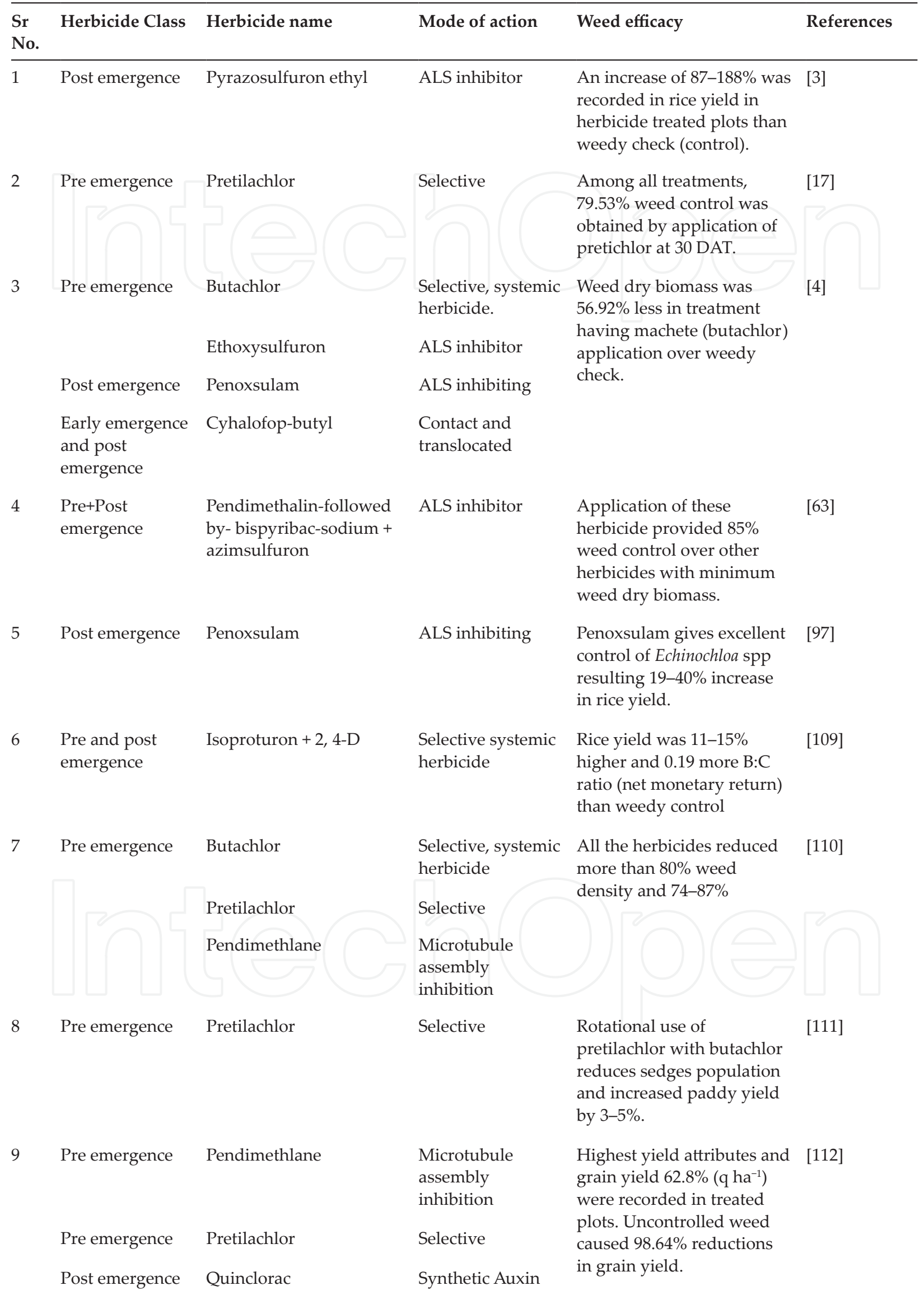




\begin{tabular}{|c|c|c|c|c|c|}
\hline $\begin{array}{l}\text { Sr } \\
\text { No. }\end{array}$ & Herbicide Class & Herbicide name & Mode of action & Weed efficacy & References \\
\hline 10 & Post emergence & Penoxsulam & ALS inhibiting & $\begin{array}{l}\text { In herbicide treated plots } \\
\text { grain yield was } 75-88 \% \text { and } \\
81-93 \% \text { better weed control } \\
\text { as compared to other } \\
\text { treatments }\end{array}$ & [113] \\
\hline 11 & $\begin{array}{l}\text { Early emergence } \\
\text { and post } \\
\text { emergence }\end{array}$ & Cyhalofop-butyl & $\begin{array}{l}\text { Contact, } \\
\text { translocated }\end{array}$ & $\begin{array}{l}\text { In herbicide treated plots } \\
27-41 \% \text { higher grain yield } \\
\text { was obtained as compared } \\
\text { to control providing } \\
75-93 \% \text { weed control }\end{array}$ & [113] \\
\hline
\end{tabular}

Table 3. Herbicides differ for their class, name, mode of action and weed control efficacy.

weed density below the threshold level instead complete removal is considered best as it is also an ecological approach of weed management [84]. Various herbicides give satisfactory weed control without reducing yield and increasing weed population pressure even if applied at lower rates [85-88]. Weed control efficiency at reduced dose of herbicide tend to be lower than recommended doses, although in many cases it may be $60-100 \%$ and acceptable commercially [82]. Application of both pre and post emergence herbicides at proper dose suppress weed flora effectively, however, the use of a single herbicide rarely gives an effective weed control in rice [78].

Rao et al. [13] suggested various herbicides packages like penoxsulam, bensulfuron, carfentrazone, molinate, bentazone, clomazone, pyrazosulfuron, fenoxaprop, propanil, bispyribacsodium and cyhalofop-butyl control weeds in rice. Further, Pacanoski and Glatkova [89] reported that herbicides i.e., propanil + bentazon, mefenacet + bensulfuron-methyl, penoxsulam, and azimsulfuron + adjuvant controlled Cyperus rotundus, Echinochloa crus-galli effectively in rice. Similarly, Kawana [90] indicated that weeds such as L. chinensis and I. rugosum can were effectively controlled using cyhalofop-butyl and bispyribac-sodium, respectively. Herbicide treatments applied with bispyribac-sodium substantially suppressed dry weight and density of weeds as compared to penoxsulam and resulted in maximum marginal rate of return [91]. Bispyribac-sodium is the most effective to the small and actively growing weeds especially against barnyard grass (alligator weed) when applied as an early post emergence herbicide applied at the 3-leaf stage of rice [92]. Both bispyribac-sodium and penoxsulam herbicides in suspension concentrate (SC) formulation were applied in combination with ethoxysulfuron as post emergence and found that bispyribac-sodium + ethoxysulfuron gave better weed control in rice [93]. Saini et al. [94] found that cyhalofop-butyl at $90 \mathrm{~g} \mathrm{ha}^{-1}$ caused significant reduction in dry matter accumulation and growth of weeds. Post-emergence application of bispyribac-sodium with metsulfuron methyl after pre-emergence application of oxyfluorfen gave the highest weed control index in fine rice [95]. Application of pendimethalin followed by bispyribac-sodium and penoxsulam reduced weed density up to $80 \%$ in rice [91], whereas application of cyhalofop-butyl at $80 \mathrm{~g} \mathrm{ha}^{-1}$ effectively controlled Echinochloa colona [96]. On the other hand, post emergence application of penoxsulam effectively controlled barnyard grass (Echinochloa crus-galli) but was inefficient in controlling broadleaf 
weeds. In contrary, the combination of penoxsulam and cyhalofop-butyl was ineffective in controlling grassy weeds [97]. Moreover, the total weed density was significantly reduced using bispyribac-sodium and cyhalofop butyl herbicides although the former caused a slight recoverable injury to the rice plant [98]. Bispyribac sodium at $30 \mathrm{~g}$ a.i. ha ${ }^{-1}$ reduced the density and biomass of weeds by up to 75 and $80 \%$, respectively; hence, its application as a post emergence herbicide proved as a viable strategy of weed control in rice [99]. In direct seeded rice, the lowest weed dry biomass was recorded using the combination of bispyribac-sodium and pretilachlor [100]. The use of bispyribac-sodium at $30 \mathrm{~g}$ a.i. $\mathrm{ha}^{-1}$ suppressed various types of weeds which includes broad leaf weeds, grasses and sedges; hence enhanced the grain and straw yield of rice by up to 17.45 and $12.30 \%$, respectively compared to the weedy check [101]. Application of herbicide mixtures proved better regarding weed control than single herbicide application at critical weed competition periods [102].

Chauhan et al. [103] evaluated the efficacy of different post emergence herbicides viz. penoxsulam + cyhalofop, fenoxaprop + ethoxy sulfuron (in combination) and bispyribac-sodium (alone) on four different types of weeds i.e., E. colona, Digitaria ciliaris, Leptochloa chinensis and E. crus-galli by applying it at four, six and eight-leaf stages. Fenoxaprop + ethoxy sulfuron gave more than $97 \%$ weed control in all weed species under study. Moreover, early application of post emergence herbicides provided high weed control than late application whilst fenoxaprop + ethoxy sulfuron controlled Digitaria ciliaris and Leptochloa chinensis, penoxsulam + cyhalofop controlled Leptochloa chinensis and bispyribac-sodium controlled E. colona effectively. Furthermore, both bispyribac-sodium and anilophos were effective against broadleaf and narrow leaf weeds. Bispyribac-sodium reduced the density of Alternanthera philoxeroides, Ammania sp.,Commelina diffusa, C. difformis, C. iria, and D. junceum while anilophos controlled Cyperus difformis, C. sanguinolentus, and C. iria effectively. However, high weed density led to significant reductions in tiller production and grain yield in rice [104]. Application of bensulfuron, bispyribac-sodium and cyhalofop-butyl at early growth stage followed by Bentazon/2methyl-4-chlorophenoxyacetic acid (MCPA) at mid growth stage control weeds effectively with increased productivity of rice [105]. Different herbicides viz. ethoxy sulfuron, cyhalofopbutyl, chlorimuron, metsulfuron, bispyribac-sodium and penoxsulam controlled different types of weeds effectively in dry seeded rice [37, 106, 107]. Hussain et al. [108] reported that bispyribac-sodium and ethoxy sulfuron were efficient with 90 and $87 \%$ weed control efficiency, respectively in rice. They further reported that maximum paddy yield and net benefits were obtained where bispyribac-sodium was applied followed by ethoxysulfuron while the lowest were recorded from weedy check.

Herbicides such as penoxsulam, ethoxysulfuron and butachlor, ethoxysulfuron were considered the most efficient with 93\% reduction in weed density in rice [109]. Bispyribac-sodium and penoxsulam at $25 \mathrm{~g} \mathrm{ha}^{-1}$ controlled weeds effectively in rice [107]. Penoxsulam (15 g a.i. $\left.\mathrm{ha}^{-1}\right)$ as post emergence was better in suppressing weed density and biomass than pendimethalin $\left(825 \mathrm{~g}\right.$ a.i. $\left.\mathrm{ha}^{-1}\right)$ as pre-emergence in rice [110].

On the other hand, the study by Khaliq et al. [91] using five pre- and post-emergence herbicides resulted in unexpected outcome. In this case, not only the germination rate of the two dominant weeds i.e., jungle rice and purple nut sedge were significantly reduced but also the 
germination and root-shoot growth of rice were negatively affected. This shows that these herbicides caused seedling mortality to both the weed and the crop irrespective of the time of application as a pre-emergence or post emergence.

Khaliq et al. [93] studied the efficacy of tank mixed pre- and post-emergence herbicides on weed control in rice. In this case, pendimethalin herbicide was tank mixed with ethoxy sulfuron ethyl at 1137 and $30 \mathrm{~g}$ a.i. ha ${ }^{-1}$ and applied as pre-emergence, respectively. Similarly, pyrazosulfuron ethyl, penoxsulam and bispyribac-sodium at 30, 15, $30 \mathrm{~g}$ a.i. ha ${ }^{-1}$ were also tank mixed with ethoxysulfuron ethyl at the same concentration, respectively and applied as post emergence. The findings of this work showed that the weed control was higher for ethoxy sulfuron with bispyribac-sodium combination than all other combinations. In general, different herbicide mixtures can be used for better weed control in rice.

\section{Weed resistance to herbicides}

Herbicide resistance is the heritable capacity for plants to grow and reproduce after herbicide treatment that would have been fatal to all but one or a very few progenitors in an antecedent population. Herbicide resistant weeds occur in both herbicide-resistant crops and conventional crops in response to selection pressure from a specific herbicide. A herbicide selects plants with natural genetic resistance to that MOA. The mechanism of herbicide MOA has been depicted in Figure 2. Those plants survive and reproduce, and if selection by the herbicide continues for several generations, the population of the resistant weed biotype increases until there is a noticeable population of weeds that herbicide will no longer control that biotype. On the other hand, both transgenic and non-transgenic herbicide-resistant crop cultivars are resistant to specific herbicides because they have been bred to survive the action of herbicide. Therefore, susceptible crop genotypes are killed by a specific herbicide while the resistant cultivars survive. When the identity of a conventional cultivar is mistaken for a resistant cultivar in the field, the conventional cultivar is killed or severely injured by the herbicide that the resistant cultivar resists without adverse effects.

Resistance of weeds to various herbicides is a well-known phenomenon but not as much focused as resistance to insecticides or fungicides [111]. Most often it is misunderstood that resistance is a problem caused by a particular active ingredient but it results from agronomic systems which totally depend on herbicides to control weeds [76]. Herbicides commonly used in rice mostly relate to acetyl co-enzyme A carboxylase (ACCase) inhibitors, acetolactate synthase (ALS), thiocarbamates, synthetic auxins and amides due to which herbicide resistance has become a serious problem in many regions [112]. Zein et al. [111] observed the evolutionary resistance of Echinochloa colonum during the years 2005-2007 against bispyribac-sodium when applied to both susceptible and resistant biotypes of Echinochloa colonum. Riar et al. [44] found some resistant populations of Echinochloa crus-galli to bispyribac-sodium and penoxsulam. El-Nady et al. [113] investigated the physiological and anatomical differences between the susceptible and resistant biotypes of Echinochloa colonum and resulted that $\mathrm{GR}_{50}$ of resistant biotype was 10.2 times greater than susceptible biotype of Echinochloa colonum where bispyribac-sodium was applied. Rahman et al. [114] tested cyhalofop-butyl, quinclorac and propanil against 10 populations of Echinochloa 


\section{*HRAC Herbicide Group}

\section{Mode of Action}

\section{Cellular Targets}

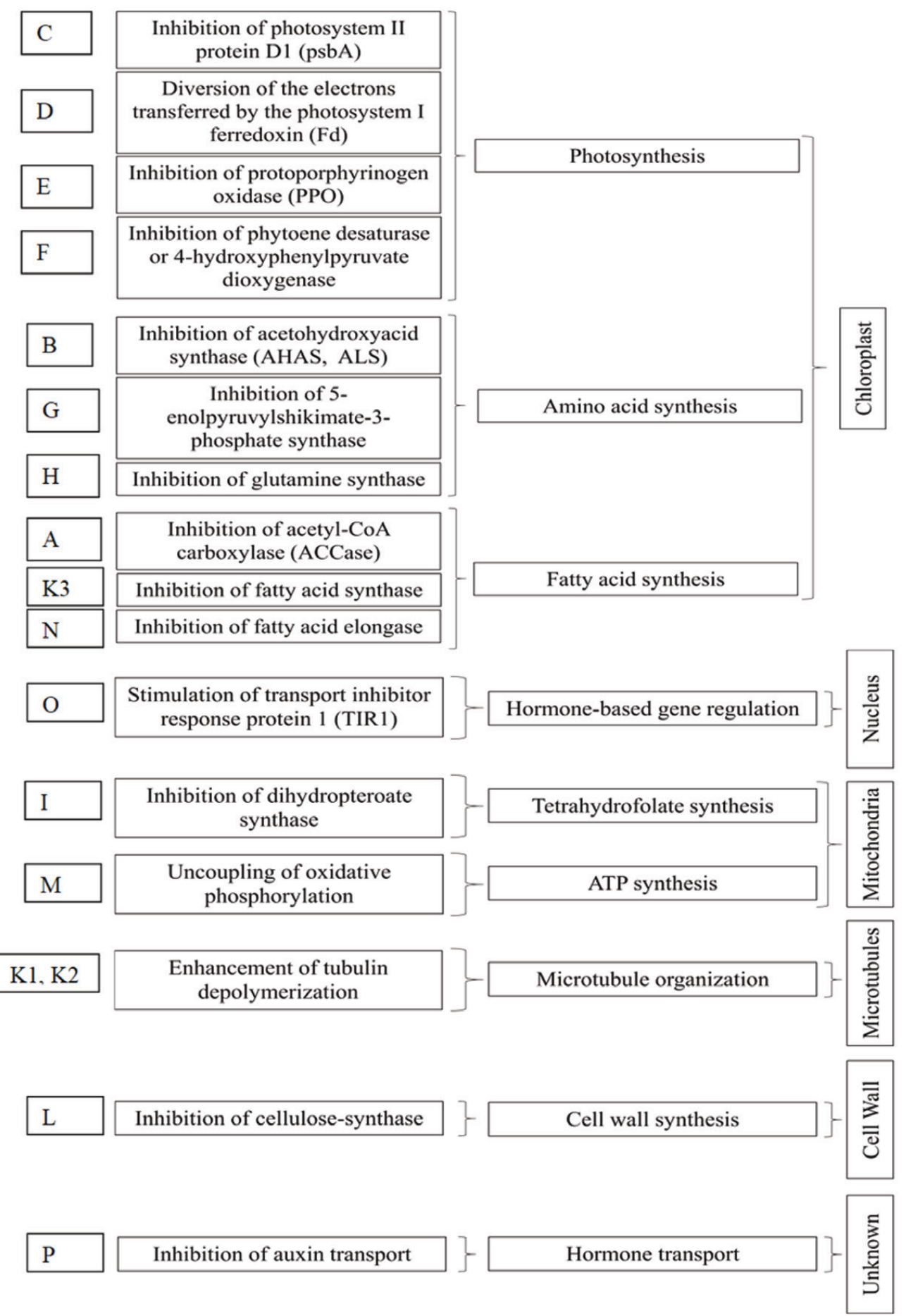

Figure 2. Herbicide class and its mode of action as defined by Herbicide Resistance Action Committee (HRAC; http:// www.hracglobal.com). Herbicides target different cellular strucures and functions and are very specific in their mechanism of action in plants. Source: [115].

crus-galli which were collected from rice field. They concluded from the ED50 values from the dose-response experiment that resistant biotypes were 4, 10 and 17 times resistant to propanil, quinclorac and cyhalofop-butyl, respectively. Regular monitoring and early 
detection of the evolution and mechanism of herbicide resistance and by adopting some suitable management strategies usefulness of herbicides may be enhanced otherwise weed control through herbicides might be at a high risk in future [116, 117].

\section{Conclusions and future needs}

Weeds being the most serious pests in agriculture have the ability to compete with the crop for available resources through rapid growth and development. Competitive abilities of weeds developed through natural selection make them more vigorous even under severe conditions. Weed control in rice crop is always remaining a difficult task for successful crop production as their presence causes severe reduction in yield and quality of crops thus increasing the cost of production. Among all the weed control methods, chemical weed control is commonly used to overcome weed infestation which is easy, quick, time saving, cost effective and the most reliable method to control weeds. There are diverse weed communities and types in rice fields. Hence, the use of a single herbicide cannot give satisfactory and cost-effective results of weed control. Not only the weeds pressure, but also the sub-optimal plant population favors weeds to grow profusely. Planting density significantly influences the growth and development as well as grain yield of rice due to its inter-specific competition. Dense plant population may lead to intra-plant competition whereas low plant population provides the space for off-types to grow easily. Integrated weed management is the best option to control weeds. By manipulating diverse weed management strategies, the competitive ability of crop over weeds for the above and below ground resources can be enhanced. Regular monitoring and early detection of the evolution and mechanism of herbicide resistance is necessary. The adoption of suitable management strategies on herbicide is also important. Hence, in the future, researchers need to develop integrated weed management strategies along with effective herbicides which do not only favor crop yield and reduce weed infestation but also discourage the resistance of weed flora to herbicides.

\section{Author details}

Umair Ashraf ${ }^{1,2,3 *}$, Saddam Hussain ${ }^{2}$, Alam Sher ${ }^{4}$, Muhammad Abrar ${ }^{5}$, Imran Khan ${ }^{2}$ and Shakeel A. Anjum²

*Address all correspondence to: umairashraf2056@gmail.com

1 Department of Botany, University of Education, Lahore, Faisalabad-Campus, Faisalabad, Punjab, Pakistan

2 Department of Agronomy, University of Agriculture, Faisalabad, Pakistan

3 Department of Crop Science and Technology, College of Agriculture, South China Agricultural University, Guangzhou, China

4 Department of Crop Cultivation and Farming System, College of Agronomy, Anhui Agriculture University, Anhui, China

5 State Key Laboratory of Grassland Agro-ecosystem, School of Life Sciences, Lanzhou University, Lanzhou, China 


\section{References}

[1] Fahad S, Hussain S, Chauhan BS, Saud S, Wu C, Hassan S, Tanveer M, Jan A, Huang J. Weed growth and crop yield loss in wheat as influenced by row spacing and weed emergence times. Crop Protection. 2015;71:101-108

[2] Rabbani N, Bajwa R, Javaid A. Interference of five problematic weed species with rice growth and yield. African Journal of Biotechnology. 2011;10:1854-1862

[3] Khaliq A, Matloob A, Chauhan BS. Weed management in dry-seeded fine rice under varying row spacing in rice wheat system of Punjab, Pakistan. Plant Production Science. 2014;17(4):321-332

[4] Ashraf U, Anjum SA, Ehsanullah KI, Tanveer M. Planting geometry induced alteration in weed infestation, growth and yield of puddled rice. Pakistan Journal of Weed Science Research. 2014;20(1):77-89

[5] Mustafa S, Sohail R, Muhammad A, Akash Z, Adeel M, Muhammad MJ. Weed management in transplanted rice through different weedicides at rice research station Bahawalnagar. Asian Journal of Plant Science and Research. 2017;7(3):11-13

[6] Singh VP, Govindra S, Mahendra S. Effect of fenoxaprop-p-ethyl on transplanted rice and associated weeds. Indian Journal of Weed Science. 2004;36:190-192

[7] Sandeep N, Singh S, Panwar KS, Malik RK, Narwal S, Singh S. Performance of acetachlor and anilofos+ethoxysulfuron for weed control in transplanted rice (Oryza sativa). Indian Journal of Agronomy. 2002;47:67-71

[8] Rekha KB, Raju MS, Reddy MD. Effect of herbicides on weed growth, grain yield and nutrient uptake in rain fed low land rice. Indian Journal of Weed Science. 2003;35:121-122

[9] Chin DV. Biology and management of barnyard grass, red sprangletop and weedy rice. Weed Biology and Management. 2001;1:37-41

[10] Mahmood K, Subhani S, Chaudhry MA, Ghafoor A. Impact of various packages of herbicides use on yield of transplanted rice. International Journal of Agriculture and Biology. 2000;2:141-143

[11] Khaliq A, Matloob A. Weed-crop competition period in three fine rice cultivars under direct-seeded rice culture. Pakistan Journal of Weed Science Research. 2011;17:229-243

[12] Rahman M, Juraimi AS, Jayasuria ASM, Man AB, Anwar P. Response of weed flora to different herbicides in aerobic rice system. Scientific Research and Essays. 2012;7:12-23

[13] Rao AN, Jhonson DE, Sivaprasad V, Ladha JK, Mortimer AM. Weed management in direct seeded rice. Advances in Agronomy. 2007;93:153-155

[14] Azmi M, Chin DV, Vongsaroj P, Johnson DE. Emerging issues in weed management of direct seeded rice in Malaysia, Vietnam and Thailand. In: Rice Is Life: Scientific Perspectives for the 21st Century, Proceedings of the World Research Conference; 4-7 November 2004; IRRI \& Tsukuba, Japan: International Research Center for Agricultural Sciences; 2005. pp. 196-198 
[15] Kumar M, Sharma G. Effect of herbicides alone and in combination on direct seeded rice. Indian Journal of Weed Science. 2005;37:197-201

[16] Ehsanullah AN, Jabran K, Habib T. Comparison of different planting methods for optimization of plant population of fine rice (Oryza sativa L.) in Punjab (Pakistan). Pakistan Journal of Agricultural Sciences. 2007;44:597-599

[17] Ali M, Sardar MSA, Biswas PK, Mannan AKMSB. Effect of integrated weed management and spacing on the weed flora and on the growth of transplanted aman rice. International Journal of Sustainable Crop Production (IJSCP). 2008;3:55-64

[18] Hossain MS, Mamun AA, Basak R, Newaj MN, Anum MK. Effect of cultivar and spacing on weed infestation and performance of transplanted aman rice in Bangladesh. Pakistan Journal of Agronomy. 2003;2:169-178

[19] Ghadiri H, Bayat ML. Effect of row and plant spacings on weed competition with pinto beans (Phaseolus vulgaris L.). Journal of Agricultural Science and Technology (JAST). 2004;6:1-9

[20] Chauhan BS, Migo T, Westerman PR, DE J. Post-dispersal predation of weed seeds in rice fields. Weed Research. 2010;50:553-560

[21] O'Donovan JT, Harker KN, Clayton GW, Newman JC, Robinson D, Hall LM. Barley seeding rate influence the effects of variable herbicide rates. Weed Science. 2001;49:746-754

[22] Weiner J, Gripenentrog HE, Kristensen L. Suppression of weeds by spring wheat (Triticum aestivum) increases with crop density and spatial uniformity. Journal of Applied Ecology. 2001;38:784-790

[23] Grichar WJ, Bessler BA, Brewer KD. Effect of row spacing and herbicide dose on weed control and grain sorghum yield. Crop Protection. 2004;23:263-267

[24] Shinggu CP, Dadari SA, Shebayan JAY, Adekpe DI, Mahadi MA, Mukhtar A, Asala $\mathrm{SW}$. Influence of spacing and seed rate on weed suppression in finger millet (Eleucine carocana). Middle East Journal of Scientific Research. 2009;4:267-270

[25] Qureshi R, Waheed A, Arshad M. Weed communities of wheat crop in district Toba Tek Singh, Pakistan. Pakistan Journal of Botany. 2009;41:239-245

[26] Jakhar GS, Mahar AQ, Abro SA, Qureshi R. Weed communities of wheat crop under diverse Edaphography of District Khairpur. Pakistan Journal of Botany. 2005;37:709-714

[27] Marwat SK, Khan MA, Ahmad M, Zafar M, Rehman FU. Ethnophyto medicines for treatment of various diseases in D. I. Khan District. Sarhad Journal of Agriculture (SJA). 2008;24:305-315

[28] Abbas RN, Tanveer A, Ali A, Zaheer ZA. Simulating the effect of Emex australis densities and sowing dates on agronomic traits of wheat. Pakistan Journal of Agricultural Sciences. 2010;47:104-110

[29] Jacob D, Syriac EK. Performance of transplanted scented rice (Oryza sativa L.) under different spacing and weed management regimes in southern Kerala. Journal of Tropical Agriculture. 2005;43:71-73 
[30] Phuong LT, Denich M, Vlek PLG, Balasubramanian V. Suppressing weeds in directseeded lowland Rice: Effects of methods and rates of seeding. Journal of Agronomy and Crop Science. 2005;191:185-194

[31] Singh S, Singh G, Singh VP, Singh AP. Effect of establishment methods and weed management practices on weeds and rice in rice-wheat cropping system. Indian Journal of Weed Science. 2005;37:51-57

[32] Savary S, Castilla NP, Elazegui FA, Teng PS. Multiple effects of two drivers of agricultural change, labour shortage and water scarcity, on rice pest profiles in tropical Asia. Field Crops Research. 2005;91:263-271

[33] Rao AN, Nagamani A. Available technologies and future research challenges for managing weeds in dry-seeded rice in India. In: Proceedings of the 21st Asian Pacific Weed Science Society Conference; 2-6 October 2007; Colombo, Sri Lanka: Asian Pacific Weed Science Society; 2007. pp. 391-401

[34] Allard JL, Kon KF, Morishima Y, Kotzian R. The crop protection industry's view on trends in rice crop establishment in Asia and their impact on weed management techniques. In: Rice Is Life: Scientific Perspectives for the 21st Century, Proceedings of the World Research Conference; 4-7 November 2004; Tsukuba, Japan; 2005. pp. 205-208

[35] Caton BP, Mortimer M, Hill JE, Johnson DE. A practical guide to weeds of rice in Asia. 2nd ed. Los Baños, Laguna, Philippines: International Rice Research Institute (IRRI); 2004. p. 58

[36] Dubey V. Ecology of jungle rice (Echinochloa colonum), a weed of rice agro-ecosystems: A case study in Bilaspur (Chhattisgarh). International Rice Research Notes. 2004;29:52-55

[37] Juraimi AS, Begum M, Yusuf MNM, Man A. Efficacy of herbicides on the control weeds and productivity of direct seed rice under minimal water conditions. Plant Protection Quarterly. 2010;25:19-25

[38] Singh Y, Singh VP, Singh G, Yadav DS, Sinha RKP, Jhonson DE, Mortimer AM. The implications of land preparation, crop establishing method and weed management on rice yield variation in the rice-wheat system in the indo-genetic plains. Field Crops Research. 2011;121:64-74

[39] Singh JKL, Guptaa RK, Bhushana L, Raob AN. Weed management in aerobic rice systems under varying establishment methods. Crop Protection. 2008;27:660-671

[40] Singh KP, Angaris NN. Ecophysiological studies of Cyperus irria L. in transplanted rice under mid hill conditions of Himachal Pradesh, Indian. Physiology and Molecular Biology of Plants. 2003;9:283-285

[41] Singh KP, Angaris NN. Studies on threshold level of Echinochloa crus-galli L. in transplanted rice under mid hill conditions of Himachal Pradesh. Advances in Plant Sciences. 2008;21:505-508

[42] Dhammu HS, Sandhu KS. Critical period of Cyperus iria L. competition in transplanted rice. In: Proceedings of 13th Australian Weeds Conference: Weeds "Threats Now and Forever?"; 8-13 September 2002; Perth, Western Australia: Plant Protection Society, Sheraton Perth Hotel; 2002. pp. 79-82 
[43] Remington TRJ, Posner L. On-farm evaluation of weed control technologies in direct seeded rice in the Gambia. In: Starkey P, Simalenga T, editors. Animal Power for Weed Control. Wageningen, the Netherlands: Technical Centre for Agricultural and Rural Cooperation, Animal Traction Network for Eastern and Southern Africa; 2000. pp. 255-261

[44] Riar DS, Norsworthy JK, Bond JA, Bararpour MT, Wilson MJ, Scott RC. Resistance of Echinochloa crus-galli populations to Acetolactate synthase-inhibiting herbicides. International Journal of Agronomy. 2012;2012:1-8

[45] Cherati FE, Bahrami H, Asakereh A. Evaluation of traditional, mechanical and chemical weed control methods in rice fields. Australian Journal of Crop Science. 2011;5: 1007-1013

[46] Prasad SM, Mishra SS, Sing SJ. Effect of establishment methods, fertility levels and weed management practices on rice (Oryza sativa). Indian Journal of Agronomy. 2001; 46:216-221

[47] Anaya AL. Allelopathy as a tool in the management of biotic resources. Critical Reviews in Plant Sciences. 2003;19:697-739

[48] Norsworthy JK, Oliveria MJ. Sicklepod (Senna obtusifolia) germination and emergence as affected by environmental factors and seeding depth. Weed Science. 2006;54(5):903-909

[49] Irshad A, Cheema ZA. Growth analysis of transplanted fine rice under different competition durations with barnyard grass. International Journal of Agriculture and Biology. 2002;4:123-126

[50] Buhler DD, Liebman M, Obrycki JJ. Review: Theoretical and practical challenges to an IPM approach to weed management. Weed Science. 2002;48:274-280

[51] Johnson DE, Mortimer AM. Issues for weed management in direct-seeded rice and the development of decision-support frameworks. In: Singh Y, Singh VP, Chauhan B, Orr A, Mortimer AM, Johnson DE, Hardy B, editors. Direct Seeding of Rice and Weed Management in the Irrigated Rice-Wheat Cropping System of the Indo-Gangetic Plains. Los Banos (Philippines)/Pantnagar (India): International Rice Research Institute/Directorate of Experiment Station, G.B Pant University of Agriculture and Technology; 2008. pp. 223-228

[52] Gibson KD, Fischer AJ, Foin TC, Hill JE. Implications of delayed Echinochloa spp. germination and duration of competition for integrated weed management in water-seeded rice. Weed Research. 2002;42:351-358

[53] Khan BM, Asif M, Hussain N, Iqbal M. Agro-economic impact of different weed management strategies in wheat. Journal of Research and Science. 2000;11:46-49

[54] Jodaugiene D, Pupaliene R, Urboniene M, Prankietis V, Prankietiene I. The impact of different types of organic mulches on weed emergence. Agronomy Research. 2006;4:197-101

[55] Heap I. Global perspective of herbicide-resistant weeds. Pest Management Science. 2014;70(9):1306-13015 
[56] Hassanuzzaman M, Rehman MI, Roy TS, Ahmed JU, Zobaer ASM. Plant characters, yield components, and yield of late transplanted aman rice as affected by plant spacing and number of seedlings per hill. Advances in Biological Research (ABR). 2009;3:201-207

[57] Kumar A, Mishra BN, Mishra PK. Effect of age of seedlings and plant density on growth and yield of hybrid rice. Annals of Agricultural Research. 2002;23(3):381-386

[58] Awan TH, Ahmad M, Ashraf MM, Ali I. Effect of different transplanting methods on paddy yield and its components at farmer's field in rice zone of Punjab. Journal of Animal and Plant Science. 2011;21:498-502

[59] Bozorgi HR, Faraji A, Danesh RK, Keshavarz A, Azarpour E, Tarighi F. Effect of plant density on yield and yield components of rice. World Applied Sciences Journal. 2011; 12:2053-2057

[60] Sunyob NB, Juraimi AS, Rahman MM, Anwar MP, Man A, Salamat A. Planting geometry and spacing influence weed competitiveness of aerobic rice. Journal of Food, Agriculture and Environment. 2012;10:330-336

[61] Chauhan BS, Johnson DE. Implications of narrow crop row spacing and delayed Echinochloa colona and Echinochloa crus-galli emergence for weed growth and crop yield loss in aerobic rice. Field Crops Research. 2010;117(2):177-182

[62] Chauhan BS, Johnson DE. Row spacing and weed control timing affect yield of aerobic rice. Field Crops Research. 2011;121:226-231

[63] Singh V, Jat ML, Ganie ZA, Chauhan BS, Gupta RK. Herbicide options for effective weed management in dry direct-seeded rice under scented rice-wheat rotation of western indo-Gangetic Plains. Crop Protection. 2016;81:168-176

[64] Ashraf U, Abbas RN, Hussain S, Mo ZW, Anjum SA, Khan I, Tang XR. Consequences of varied planting geometry and early post emergence herbicides for crop-weed interventions in rice under semi-arid climate. Planta Daninha. 2016;34:737-746

[65] Dass A, Shekhawat K, Choudhary AK, Sepat S, Rathore SS, Mahajan G, Chauhan BS. IWeed management in rice using crop competition-a review. Crop Protection. 2017;95:45-52

[66] Nain S, Dinesh K, Thenua OVS, Tyagi VK. Influence of spacing and weed management on rice (Oryza sativa) varieties under system of rice intensification. Indian Journal of Agronomy. 2012;57:138-142

[67] Rasool F, Habib R, Bhat MI. Evaluation of plant spacing and seedlings per hill on rice (Oryza sativa L.) productivity under temperate conditions. Pakistan Journal of Agricultural Sciences. 2012;49:169-172

[68] Asmamaw BA. Effect of planting density on growth, yield and yield attributes of rice (Oryza sativa L.). African Journal of Agricultural Research (AJAR). 2017;12(35):2713-2721

[69] Amin M, Khan MA, Khan EA, Ramzan M. Effect of increased plant density and fertilizer dose on the yield of rice variety ir-6. Journal of Research and Science. 2004;15:9-16 
[70] Tari DB, Pirdashti HA, Nasiri M. Investigation some agronomical traits of rice under different transplanting dates, planting spacing. World Applied Sciences Journal. 2009; 6:1021-1027

[71] Uddin MJ, Ahmed S, Rashid MH, Hasan MM, Zaman MA. Effect of spacings on the yield and yield attributes of transplanted aman rice cultivars in medium lowland ecosystem of Bangladesh. Journal of Agricultural Research. 2011;49:465-476

[72] Sultana MR, Rahman MM, Rahman MH. Effect of row and hill spacing on the yield performance of boro rice (cv. BRRI dhan45) under aerobic system of cultivation. Journal of the Bangladesh Agricultural University. 2012;10:39-42

[73] Alam MS, Baki MA, Sultana MS, Ali KJ, Islam MS. Effect of variety, spacing and number of seedlings per hill on the yield potentials of transplant aman rice. International Journal of Agronomy and Agricultural Research. 2012;2:10-15

[74] Baloch AW, Soomro AM, Javed MA, Ahmed M, Bughio HR, Bughio MS, Mastoi NN. Optimum plant density for high yield in Rice (Oryza sativa L.). Asian Journal of Plant Sciences. 2002;1:25-27

[75] Jacob D, Syriac EK, Pushpakumari R. Spacing and weed management in transplanted basmati rice. The Madras Agricultural Journal. 2005;92:224-229

[76] Senseman SA. Herbicide handbook. 9th ed. Lawrence, US: Weed Science Society of America; 2007. p. 493

[77] Al-Mamun MA, Shultana R, Bhuiyan MKA, Mridha AJ, Mazid A. Economic weed management options in winter rice. Pakistan Journal of Weed Science Research. 2011; 17:323-331

[78] Singh VP, Singh G, Singh RK. Integrated weed management in direct seeded spring sown rice under rain-fed low valley situation of Uttaranchal. Indian Journal of Weed Science. 2001;33:63-66

[79] Marwat KB, Khan IA, Hassan G. Efficacy of different pre and post-emergence for controlling weeds in chickpea. Pakistan Journal of Weed Science Research. 2004;10:51-54

[80] Gitsopoulos TK, Froud-Williams RJ. Effects of oxadiargyl on direct-seeded rice an Echinochloa crus-galli under aerobic and anaerobic conditions. Weed Research. 2004; 44:329-334

[81] Ahmed GJU, Mamun AA, Hossain SMA, Mridha AJ, Hossain ST. Agro-economic study of weed control in direct seeded Aus rice in the farmers' field. Annals of Bangladesh Agriculture. 2000;8(2):111-118

[82] Zhang J, Weaver SE, Hamill AS. Risks and reliability of using herbicides at below-labeled rates. Weed Tech. 2000;14:106-115

[83] Talgre L, Lauringson E, Koppel M. Effect of reduced herbicide dosages on weed infestation in spring barley. Zemdirbyste-Agriculture. 2008;95:194-201 
[84] Barroso J, Ruiz D, Escribano C, Barrios L, Fernandez-Quintanilla C. Comparison of three chemical control strategies for Avena sterilis ssp. ludoviciana. Crop Protection. 2009; 28:393-400

[85] Walker SR, Medd RW, Robinson GR, Cullis BR. Improved management of Avena ludoviciana and Phalaris paradoxa with more densely sown wheat and less herbicide. Weed Research. 2002;42:257-270

[86] Auskalnis A, Kadzys A. Effect of timing and dosage in herbicide application on weed biomass in spring wheat. Agronomy Research. 2006;4:133-136

[87] Barros JFC, Baschand G, Carvalho M. Effect of reduced doses of a post-emergence herbicide to control grass and broadleaved weeds in no-till wheat under Mediterranean conditions. Crop Protection. 2007;26:1538-1545

[88] Islam T, Bhowmic MK, Ghoshand RK, Sounda G. Effect of pretilachlor on weed control and yield of transplanted rice. Journal of Environment and Ecology. 2000;19:265-268

[89] Pacanoski Z, Glatkova G. The use of herbicides for weed control in direct wet-seeded Rice (Oryza sativa L.) in rice production regions in the republic of Macedonia. Plant Production Science. 2009;45:113-118

[90] Kawana Y. Control of Grass Weeds in Wet Direct-Seeded Rice. PhilRice, Muñoz, Nueva Ecija: Short-Term JICA Expert Report; 2000. pp. 32-33

[91] Khaliq A, Matloob A, Shafiq HM, Cheema ZA, Wahid A. Evaluating sequential application of pre and post emergence herbicides in dry seeded fine rice. Pakistan Journal of Weed Science Research. 2011;17:111-123

[92] Odero DC, Rainbolt C. Weed Management in Rice. Institute Food Agric. Sci. Univ. Florida, USA: Florida Cooperative Extension Service; 2011. pp. 1-5

[93] Khaliq A, Matloob A, Mahmood S, Abbas RN, Khan MB. Seeding density and herbicide tank mixtures furnish better weed control and improve growth, yield and quality of direct seeded fine rice. International Journal of Agriculture and Biology. 2012;14:499-408

[94] Saini JP, Angiras NN, Singh CM. Efficacy of cyhalofop-butyl in controlling weeds in transplanted rice (Oryza sativa). Indian Journal of Agronomy. 2001;46:222-226

[95] Gnanavel I, Anbhazhagan R. Bio-efficacy of pre and post-emergence herbicides in transplanted aromatic basmati rice. Research Journal of Agricultural Science. 2010;1:315-317

[96] Choubey NK, Kobe SS, Tripathi RS. Relative performance of cyhalofop butyl for weed control in direct seeded rice. Indian Journal of Weed Science. 2001;33:132-135

[97] 2003Ottis BV, Talbert RE, Malik MS, Ellis AT. Rice weed control with Penoxsulam (grasp). B.R. Wells Rice Research Studies;517:144-146

[98] Rao AS, Ratnam M. Evaluation of post emergence herbicides on weed control in rice nursery. Pakistan Journal of Weed Science Research. 2010;16:387-392 
[99] Khaliq A, Matloob A, Ahmad N, Rasul F, Awan IU. Post emergence chemical weed control in direct seeded fine rice. Journal of Animal and Plant Science. 2012;22:1101-1106

[100] Javier EF, Furuya S, Soriano R, Garcia F. Management of wet direct-seeded rice. II: Weed control by water \& herbicides. Philippine Journal of Crop Science. 2005;30:11-17

[101] Begum M, Juraimi A, Omar SS, Rajan A, Azmi M. Effect of herbicides for the control of Fimbristylis miliacea (L.) Vahl. In rice. Journal of Agronomy. 2008;7(3):251-257

[102] Shukor JA, Mahfuza B, Yusof M, Najib M, Azmi M. Efficacy of herbicides on the control of weeds and productivity of direct seeded rice under minimal water conditions. Plant Protection Quarterly. 2010;25:19-25

[103] Chauhan BS, Abugho SB. Effect of growth stage on the efficacy of postemergence herbicides on four weed species of direct-seeded rice. The Scientific World Journal. 2012;2012:1-7

[104] Ranjit JD, Suwanketnikom R. Response of weeds and yield of dry direct seeded rice to tillage and weed management. Weed Science. 2005;33:63-66

[105] Anwar MP, Juraimi AS, Puteh A, Man A, Rahman MM. Efficacy, phytotoxicity and economics of different herbicides in aerobic rice. Acta Agriculturae Scandinavica. 2012; 62(7):1-12

[106] Mann RA, Ahmad S, Hassan G, Baloch MS. Weed management in direct seeded rice crop. Pakistan Journal of Weed Science Research. 2007;13:219-226

[107] Mahajan G, Chauhan BS, DE J. Weed management in aerobic rice in northwestern indoGangetic plains. Journal of Crop Improvement. 2009;23:366-382

[108] Hussain S, Ramzan M, Akhter M, Aslam M. Weed management in direct seeded rice. Journal of Animal and Plant Science. 2008;18(2-3):86-88

[109] Ashraf MM, Awan TH, Manzoor Z, Ahmad M, Safdar ME. Screening of herbicides for weed management in transplanted rice. Journal of Animal and Plant Science. 2006;16:92-95

[110] Jabran K, Farooq M, Hussain M, Ehsanullah KMB, Shahid M, Lee DJ. Efficient weeds control with penoxsulam application ensures higher productivity and economic returns of direct seeded rice. International Journal of Agriculture and Biology. 2012;14:901-907

[111] Zein AA, Abd-El-Baky MA, Hassan SM, Derbalah AS, Hamza AM. Evolution and mechanism of Rice weeds resistance to herbicides I-resistance of Echinochloa colonum to Bispyribac-sodium herbicide with respect to its effect on chlorophyll content. Journal of Agricultural Research. 2010;36:480-494

[112] Valverde BE, Itoh K. World rice and herbicide resistance. In: Powles SB, Shaner DL, editors. Herbicide Resistance and World Grains. Boca Raton, Florida (USA): CRC Press LLC; 2001. pp. 195-249 
[113] El-Nady M, Hamza A, Derbalah A. Echinochloa colonum resistance to bispyribacsodium in Egypt-occurrence and identification. Journal of Plant Protection Research. 2012;52(1):139-145

[114] Rahman MM, Sahid IB, Juraimi AS. Study on resistant biotypes of Echinochloa crus-galli in Malaysia. Australian Journal of Crop Science. 2010;4:107-115

[115] Délye C, Jasieniuk M, Le Corre V. Deciphering the evolution of herbicide resistance in weeds. Trends in Genetics. 2013;21:649-58

[116] Fischer AJ, CMD A, Bayer E, Hill JE. Herbicide-resistant Echinochloa oryzoides and E. phyllopogon in California Oryza sativa fields. Weed Science. 2000;48:225-230

[117] Osuna MD, Vidotto F, Fischer AJ, Bayer DE, Prado R, Ferrero A. Cross-resistance to bispyribac-sodium and bensulfuron-methyl in Echinochloa phyllopogon and Cyperus difformis. Pesticide Biochemistry and Physiology. 2002;73:9-17 

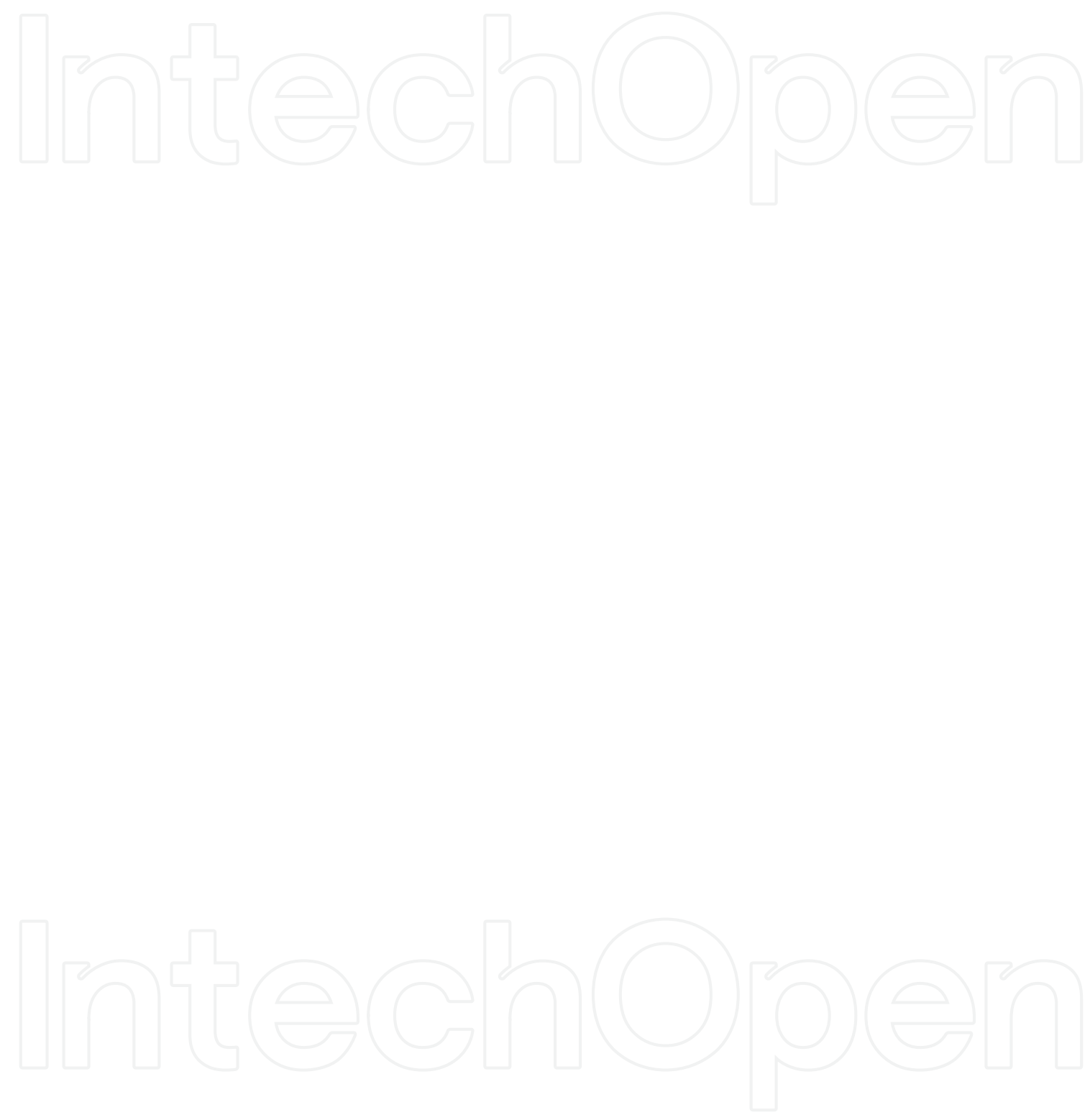


\title{
Roots of Perennial Grasses in the Recovery of Soils Degraded by Coal Mining in Southern Brazil
}

\author{
Lizete Stumpf, Otávio dos Anjos Leal, \\ Eloy Antonio Pauletto and \\ Luiz Fernando Spinelli Pinto
}

Additional information is available at the end of the chapter

http://dx.doi.org/10.5772/intechopen.79153

\begin{abstract}
Revegetation of degraded soils is crucial to prevent erosion and improve soil structure and quality. We aimed to elucidate the role of the root system of grasses on the reclamation of a soil constructed after coal mining. In Candiota city, in Brazil, perennial grasses (Hemarthria, Paspalum, Cynodon, and Brizantha) were cultivated for 103 months, when soil samples were collected from $0.00-0.30 \mathrm{~m}$ layer. The root development of these species substantially decreased in depth, reflecting soil restrictive conditions, as high soil penetration resistance, especially below $0.10 \mathrm{~m}$, assigned to the use of heavy machinery during soil construction. Below $0.10 \mathrm{~m}$ depth, fine and flattened roots were observed, which penetrated through the cracks of compacted soil layers. Regardless of the soil layer, all plant species had a greater proportion of roots $<0.49$ than $>0.50 \mathrm{~mm}$ diameter class, averaged 92 and $8 \%$, respectively. Below $0.10 \mathrm{~m}$ depth, Brizantha increased the proportion of roots $>0.50 \mathrm{~mm}$ diameter class, while the other grasses increased the proportion of roots $<0.49 \mathrm{~mm}$ diameter class. The highest root density, volume, and length observed for Brizantha along the soil profile indicate its high potential to improve physical attributes and therefore the quality of the constructed soil.
\end{abstract}

Keywords: surface mining, soil compaction, soil penetration resistance, root growth, Urochloa brizantha

\section{Introduction}

According to the World Coal Association, the global coal reserves are approximately 860 billion tons, with a useful lifetime of approximately 109 years. These reserves are located 
mainly in five countries, United States of America (USA), Russia, China, Australia, and India. Together, these countries possess $75 \%$ of the world's coal reserves. In Latin America, Brazil has one of the largest coal deposits [1], which are used to supply the following sectors: electric power $(81.1 \%)$, paper and cellulose $(4.9 \%)$, petrochemicals $(3.3 \%)$, food production $(2.9 \%)$, ceramics $(2.6 \%)$, metallurgy and cement $(1.3 \%)$, and others (2.7\%) [2]. In Brazil, the greatest coal deposits are located in Rio Grande do Sul (RS) State, approximately 28.6 billion tons. The Candiota Mine in southwest of RS alone contains 38\% of the national reserves [3]. Due to the shallow depth of the coal deposits in the Candiota Mine, which ranges from 10 to $25 \mathrm{~m}$ from the soil surface, it is exploited by opencast mining. First, the superficial soil horizons are removed and stored to be later used for the topographic recomposition of the area, covering the site previously mined. Thereafter, the rocks are removed to expose the coal deposits, which can be then exploited. Into the opened caves, the overburden (a mixture of rocks and discarded coal fragments) is deposited and leveled using tractors. Finally, the soil horizons, initially removed to expose the coal, are deposited on the surface of the soil under "construction," completing the topographic recomposition of the area and originating the so-called "constructed soil" or mine soil.

Constructed soils are young soils in terms of pedological processes and horizon development. These soils usually have high level of degradation and compaction as well as low levels of organic matter $(\mathrm{OM})$, as a result of the mining and topographic recomposition of the landscape, as previously mentioned, dramatically hindering the reclamation of the area $[4,5]$. Therefore, the utilization of the superficial soil horizons (topsoil), which concentrate OM and nutrients, to cover constructed soils followed by the revegetation of the area is crucial to accelerate the recovery of the soil quality [6]. However, it is important to mention that the irregular distribution of the topsoil material on the soil surface can aggravate the level of soil compaction [7], disfavoring the establishment of the cover crops used for revegetation, and increasing the vulnerability of the soil to erosion, hence retarding the reclamation of mine soils [8].

Due to the high perturbation of the ecosystem after surface mining activities and to the construction of a new soil profile, a time point "zero" of this soil with respect to soil development processes can be assumed. Within this scenario, the assessment and monitoring of the evolution of soil attributes is an extraordinary opportunity to improve our knowledge on the role of plant roots on the formation and stabilization of soil aggregates as well as on the accumulation and distribution of OM in the soil [9]. In the southeast of USA [10], similarities between the structure of a mine soil and that of a natural soil (unmined) were observed only after 23 years of reclamation.

In the southeast of Nigeria [11], higher bulk density was observed in a mine soil in comparison to that of a natural soil even after 30 years of revegetation. On the other hand, in the USA, the development of horizons of a constructed soil was observed in a relatively short time span of 10-15 years, with organic carbon accumulation, mainly within $0.00-0.10$ m layer, after 5-10 years of soil reclamation [12]. In the north of China [8], the effect of the root system of cover crops on the formation of aggregates in the constructed soil was more pronounced after 5-10 years of revegetation. In a study carried out in Germany [13], it was verified that in the first four years of revegetation, the physical attributes of a constructed soil were still highly variable, and the authors recommended the implantation of perennial grasses with deep root system in the area in order to improve the soil structure more efficiently and rapidly. 
In a previous work, we proposed a soil aggregation hierarchy for highly compacted constructed soils different from that hierarchy normally observed in unmined soils, as agricultural soils for example [14]. After coal mining in southern Brazil, the soil was revegetated with perennial grasses, and after 8.6 years of revegetation, we noticed first a root-induced disintegration of large cohesive aggregates formed by compression, followed by a re-aggregation process, with sequential formation and stabilization of the new aggregates. In this way, the interpretation of correlations between soil attributes usually observed for unmined soils cannot be, occasionally, directly transferred and applied to mine soils because they have different soil aggregation dynamics, at least at the beginning of soil revegetation. These findings reinforce the need and the opportunity to assume constructed soils as a new system, where monitoring of soil and plant attributes in the long term is a key to understand the formation of this new soil profile and moreover to anticipate strategies to improve soil quality [5].

The utilization of cover crops and the addition of OM to agricultural soils are known to promote the amelioration of soils poorly structured [15-17]. In this sense, special attention is given to grasses due to their high root density, which promotes the approximation of soil particles via water absorption along the soil profile, and therefore improves soil physical attributes. Additionally, root exudates increase the activity of soil microorganisms, consequently stimulating the aggregate formation and stabilization [18]. Hence, grasses have been considered indispensable plants in terms of soil preservation and reclamation [19].

Studies dedicated to investigate the root system development, its distribution, extension, and activity are extremely important to elucidate the effect of the plants, particularly the effect of the roots, on soil attributes, especially on attributes of unprotected and severely degraded soils, which are naturally more vulnerable to the intensification of the degradation processes. Despite the adverse plant growing conditions usually observed in constructed soils, especially in soils under early stage of reclamation, and the remarkable potential of grasses as regenerators of soil quality, few studies have been devoted to obtain direct measurements of root parameters of grasses in these soils [20].

This work is part of a long-term experiment that has been carried out for 15 years in Candiota, Brazil, to evaluate the potential of different grass species to improve the attributes of a soil constructed after surface coal mining. In our study, we focused to understand how the root system of the grasses develops and adapts when subjected to the severe soil compaction conditions of the constructed soil.

\section{Methodology}

The experimental site is located in Candiota city, in a coal mining area (31 $33^{\prime} 56^{\prime \prime} \mathrm{S}$ and $53^{\circ} 43^{\prime} 30^{\prime \prime}$ W), which is under concession of the Riograndense Mining Company. The soil was constructed in early 2003. The topsoil used to cover the overburden was composed mainly by the $\mathrm{B}$ horizon of the natural soil (prior to mining), a Rhodic Lixisol [21], with high clay content (466 g kg-1 clay), dark red color (2.5 YR 3/6), and lower OM content (12 $\mathrm{g} \mathrm{kg}^{-1}$ ) compared to the A horizon $\left(21 \mathrm{~g} \mathrm{~kg}^{-1}\right)$. The main steps of the coal extraction and soil construction were: (I) removal of A, B, and C horizons of the Rhodic Lixisol; (II) removal of saprolite and overburden 
with a dragline excavator; (III) coal extraction; (IV) filling of the caves with overburden spoils and leveling of these piles with heavy machinery aiming the topographic recomposition of the area; and (V) distribution of the topsoil (separated in step I) on the surface of the constructed soil. Illustration of the process of soil construction in Candiota was earlier reported [22].

The experiment was installed in November/December 2003 in a randomized block design with four replicates (each plot with $4 \mathrm{~m} \times 5 \mathrm{~m}=20 \mathrm{~m}^{2}$ ). Types of grasses and planting materials used as treatments consisted of perennial summer grasses: Hemarthria altissima (15 cuttings $\left.\mathrm{m}^{-2}\right)$, Paspalum notatum $\mathrm{cv}$. Pensacola $\left(50 \mathrm{~kg}\right.$ of seed ha $\left.{ }^{-1}\right)$, Cynodon dactylon $\mathrm{cv}$. Tifton (15 cuttings $\left.\mathrm{m}^{-2}\right)$, and Urochloa brizantha $\left(10 \mathrm{~kg}\right.$ of seed ha $\left.{ }^{-1}\right)$. Due to the severe soil compaction caused by the intense use of heavy machinery during the soil construction, prior to the implantation of the cover crops, the soil was chiseled with a bulldozer up to $0.15 \mathrm{~m}$ depth and also received dolomitic limestone equivalent to $10.4 \mathrm{Mg} \mathrm{ha}^{-1}$ effective calcium carbonate rating and $900 \mathrm{~kg} \mathrm{ha}^{-1}$ of NPK fertilizer, 5-20-20 (45 kg N, $180 \mathrm{~kg} \mathrm{P}_{2} \mathrm{O}_{5^{\prime}}$ and $\left.180 \mathrm{~kg} \mathrm{~K}_{2} \mathrm{O}\right)$. Annually, all plots received $250 \mathrm{~kg} \mathrm{ha}^{-1}$ of NPK fertilizer, 5-30-15 (12.5 kg N, $75 \mathrm{~kg} \mathrm{P}_{2} \mathrm{O}_{5^{\prime}}$, and $37.5 \mathrm{~kg} \mathrm{~K}_{2} \mathrm{O}$ ), and $250 \mathrm{~kg} \mathrm{ha}^{-1}$ of ammonium sulfate.

The root sampling was performed in July 2012, 103 months after the implantation of the grasses. Roots were sampled by the monolith method [23] using a nail board $(0.40 \mathrm{~m}$ length $\times 0.30 \mathrm{~m}$ height $\times 0.035 \mathrm{~m}$ wide), where the nails were set at equidistant positions of $0.05 \mathrm{~m}$ on the board. One monolith per plot was collected, totalizing 16 nail boards (four replicates per treatment). The monoliths were packed with plastic film and taken to the laboratory for washing and root separation. The washing consisted of soaking the plate for $24 \mathrm{~h}$ in a $0.2 \mathrm{M} \mathrm{NaOH}$ solution for soil dispersing and to facilitate the cleaning of the roots. Hereafter, they were washed in running water or with water jets to remove soil particles from the board. The nails allowed adequate fixation of the roots on the plate at the time of washing. In order to assure the fixation, one metal mesh at the bottom and other in front of the plate were used. After washing, the roots along the monolith were stratified in three layers, $0.00-0.10,0.10-0.20$, and $0.20-0.30 \mathrm{~m}$, cut and washed on a $1 \mathrm{~mm}$ mesh sieve, stored in plastic bags, and refrigerated at $2^{\circ} \mathrm{C}$ temperature. The roots were scanned on an HP Scanjet 3570C scanner, and the software SAFIRA [24] was used to analyze the images and to obtain root volume (RV), root length (RL), root area (RA), and mean root diameter (MRD). After scanning, the roots were oven-dried at $65^{\circ} \mathrm{C}$ for $72 \mathrm{~h}$, and the root dry mass (RDM) was determined. The root density (RD) of each layer was calculated by the ratio of RDM to the respective soil volume occupied by the root.

The soil mechanical penetration resistance (PR) was measured at the time of the root sampling at 48 points of the experimental area. The PR was evaluated up to 0.30 soil depth using an impact penetrometer [25].

\section{Results and discussion}

The qualitative evaluation of the root system of the cover crops was performed based on the monoliths showed in Figures 1-4. The monoliths allowed to observe overburden layers in some of the replicates, generally below $0.20 \mathrm{~m}$ depth, as shown in monoliths III and IV (Hemarthria altissima and Cynodon dactylon), monolith I (Paspalum notatum), and monoliths I 
and IV (Urochloa brizantha). The variability of the overburden layer thickness reflects the heterogeneous distribution of the topsoil material on the overburden surface at the time of the soil construction, as earlier discussed [5].

Although overburden layers were evidenced within $0.15-0.20 \mathrm{~m}$ soil layer, apparently they did not limit root development to $0.20-0.30 \mathrm{~m}$ layer, since roots of some plant species were observed at this depth. However, it is relevant to highlight that the presence of overburden becomes problematic if associated with pyrite, which is responsible for acid drainage processes that are potentially harmful to the environment. From the plant survival perspective, the deep root growth is beneficial in terms of plant water use strategies and anchoring, but from the environmental point of view, if the roots reach an overburden plus pyrite layer, they can intensify the sulfurization process, once the macro porous created by the roots increase the water infiltration into the soil and the migration of oxygen to subsurface layers [26].

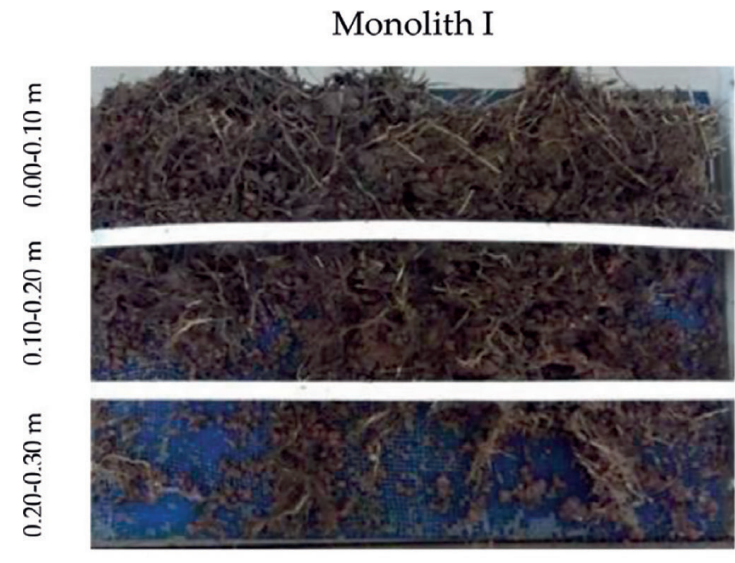

Soil layer: $0.00-0.30 \mathrm{~m}$

Overburden layer: absent

Monolith III

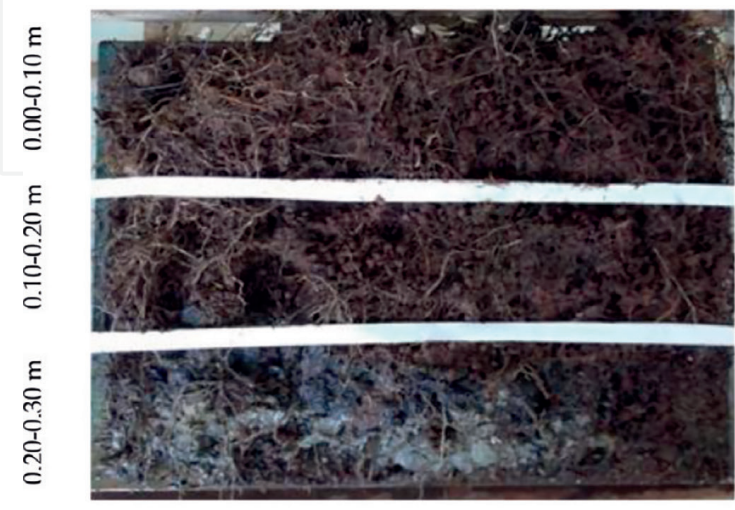

Soil layer: $0.00-0.20 \mathrm{~m}$

Overburden layer: $0.20-0.30 \mathrm{~m}$
Monolith II

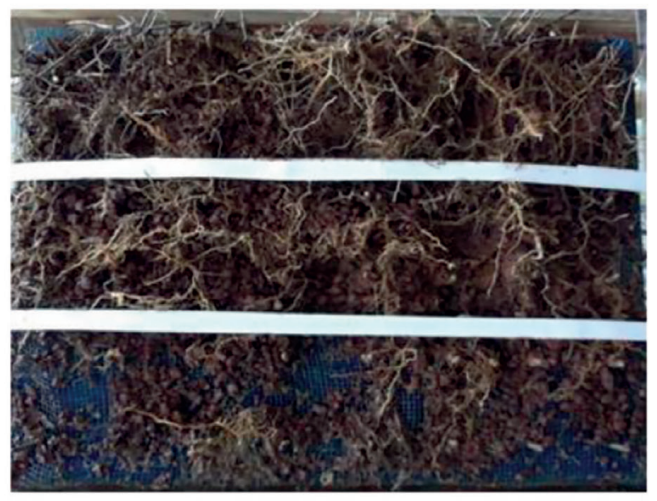

Soil layer: $0.00-0.30 \mathrm{~m}$

Overburden layer: absent

Monolith IV

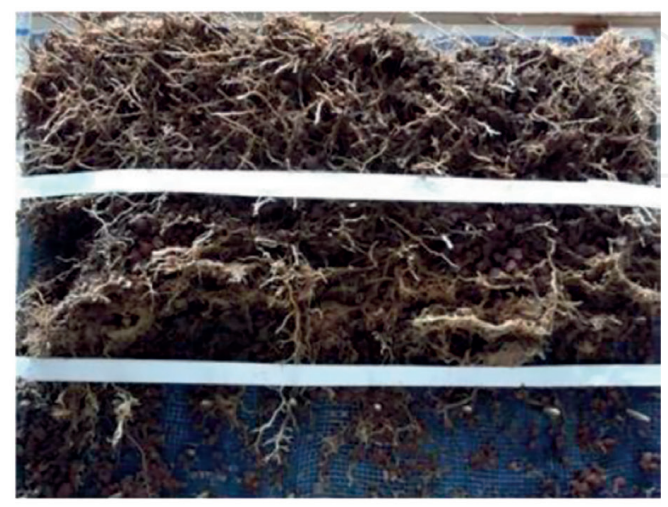

Soil layer: $0.00-0.20 \mathrm{~m}$

Overburden layer: $0.20-0.30 \mathrm{~m}$

Figure 1. Qualitative evaluation of Hemarthria altissima roots after washing of the soil monoliths and soil/overburden distribution within $0.00-0.30 \mathrm{~m}$ layer. 
Monolith I

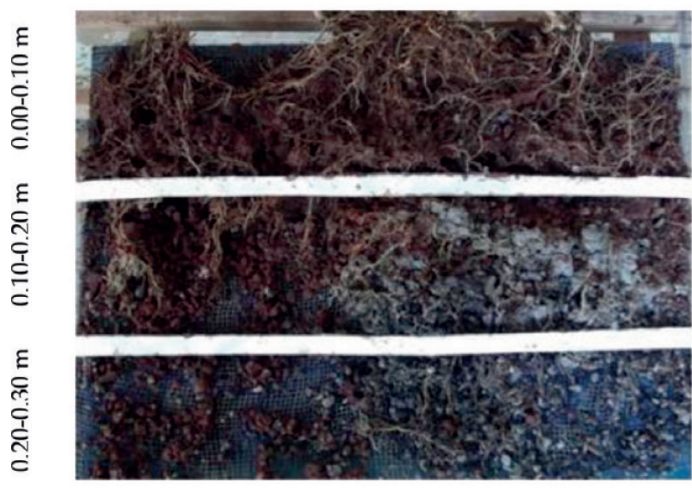

Soil layer: $0.00-0.18 \mathrm{~m}$

Overburden layer: $0.18-0.30 \mathrm{~m}$

Monolith III

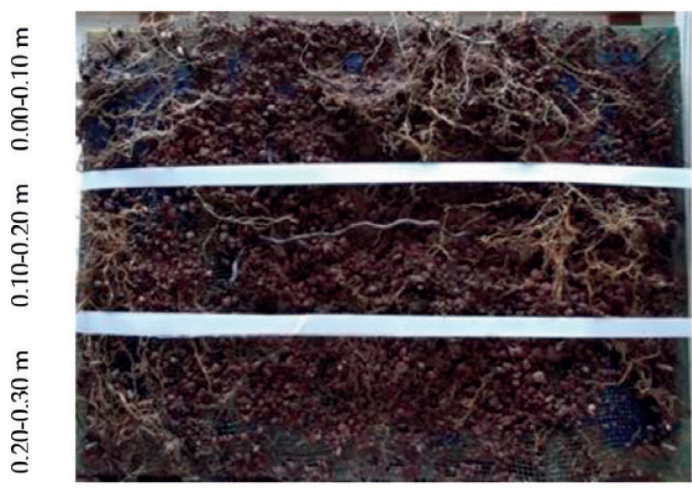

Soil layer: $0.00-0.30 \mathrm{~m}$

Overburden layer: absent
Monolith II
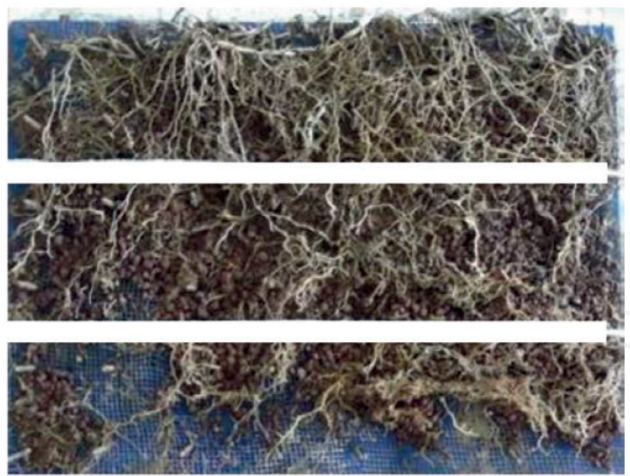

Soil layer: $0.00-0.30 \mathrm{~m}$

Overburden layer: absent

Monolith IV

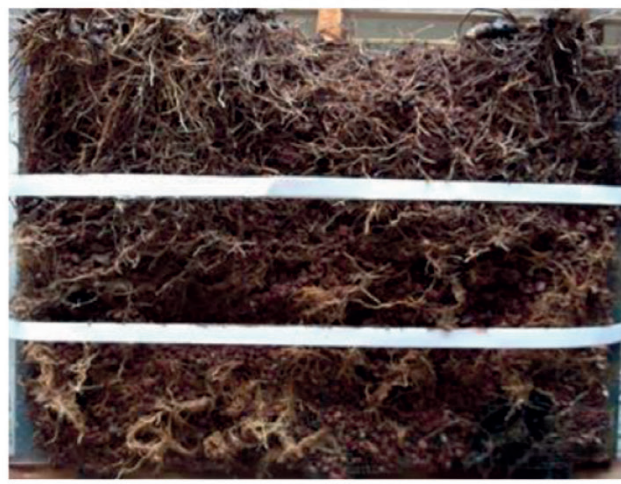

Soil layer: $0.00-0.30 \mathrm{~m}$

Overburden layer: absent

Figure 2. Qualitative evaluation of Paspalum notatum cv. Pensacola roots after washing of the soil monoliths and soil/ overburden distribution within $0.00-0.30$ m layer.

The depth of rooting is a valuable indicator of the root system quality [27]. In our study, we observed that the four plant species were able to develop roots up to $0.30 \mathrm{~m}$ depth, but most of the roots were concentrated at 0.00-0.10 m layer (Table 1). Overall, the proportion of the root system of Hemarthria altissima, Cynodon dactylon, and Urochloa brizantha substantially decreased from $0.10-0.20$ to $0.20-0.30 \mathrm{~m}$ layer. Interestingly, the root system of Paspalum notatum behaved differently from the other species and developed more uniformly within $0.10-0.30 \mathrm{~m}$ layer as evidenced by the RD, RV, RL, and RA proportions along the soil profile (Table 1). These findings indicate the ability of this species to establish its root system along the soil profile $(0.00-0.30 \mathrm{~m})$ even though the overburden layer and the higher PR observed near to $0.20 \mathrm{~m}$ depth in this treatment (Figures 2 and 5) could have hindered the root system deepening.

In general, approximately 44 and $75 \%$ of the root mass of grasses develops at $0.00-010$ and 0.00-0.30 m layer, respectively [28]. Similar data have also been observed for the root growth of an annual grass (Bromus tectorum) and a perennial grass (Agropyrom desertorum), and nearly 
Monolith I

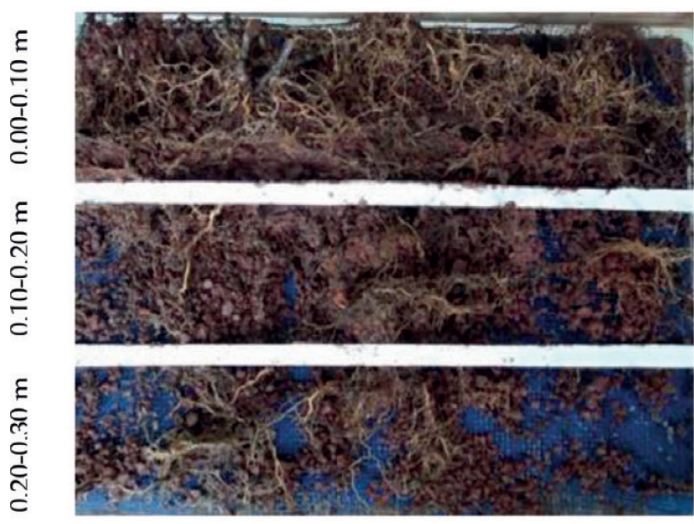

Soil layer: 0.00 - $0.30 \mathrm{~m}$

Overburden layer: absent

Monolith III

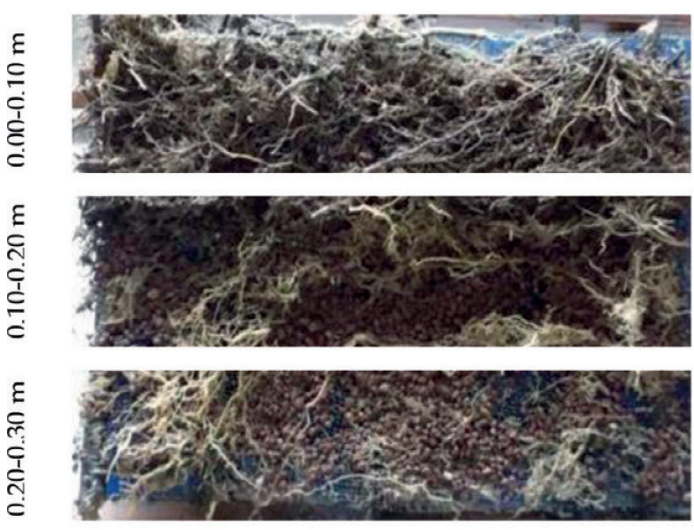

Soil layer: $0.00-0.25 \mathrm{~m}$

Overburden layer: $0.25-0.30 \mathrm{~m}$
Monolith II
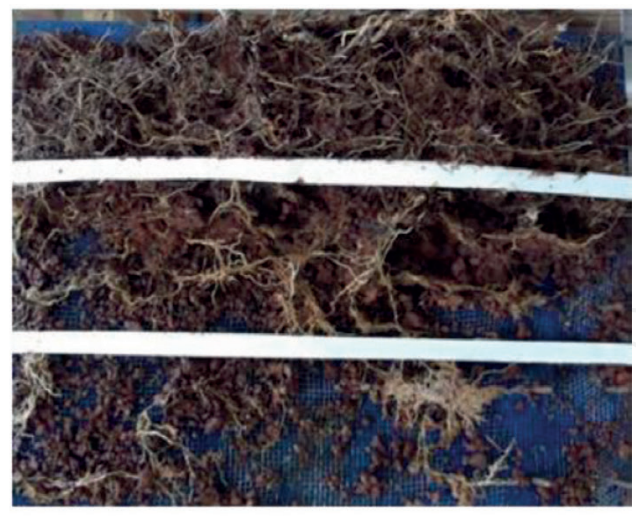

Soil layer: $0.00-0.30 \mathrm{~m}$

Overburden layer: absent

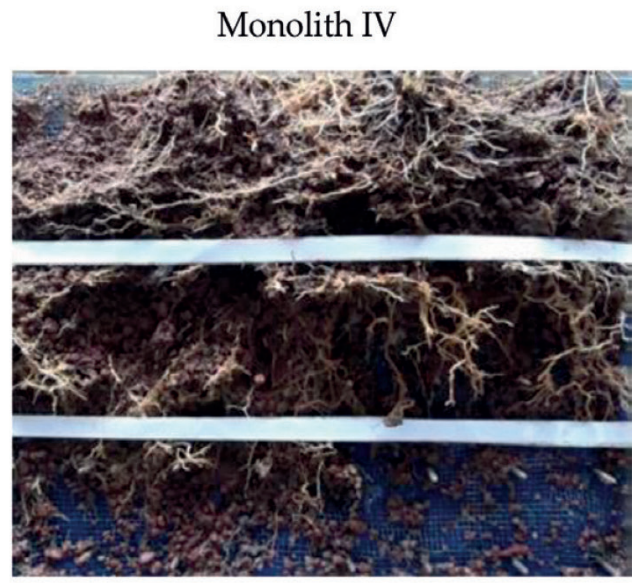

Soil layer: $0.00-0.20 \mathrm{~m}$

Overburden layer: $0.20-0.30 \mathrm{~m}$

Figure 3. Qualitative evaluation of Cynodon dactylon cv. Tifton roots after washing of the soil monoliths and soil/ overburden distribution within $0.00-0.30$ m layer.

$75 \%$ of the root biomass was distributed within the first $0.30 \mathrm{~m}$ depth [29]. In our study, the concentration of roots at $0.00-0.10 \mathrm{~m}$ layer was substantially higher than those reported earlier. The proportion of root parameters for the four grasses for the upper $0.10 \mathrm{~m}$ ranged from 62 to $68 \%$ for RD, from 54 to $63 \%$ for RV, from 52 to $61 \%$ for RL, and from 53 to $61 \%$ for RA (Table 1). Around $95 \%$ of the plant species develop a deeper root system in sandy soils than in clayey soils [30]. Considering that the clay content of the constructed soil is considerably high along the soil profile ( $453 \mathrm{~g} \mathrm{~kg}^{-1}$ at $0.00-0.10 \mathrm{~m}, 478 \mathrm{~g} \mathrm{~kg}^{-1}$ at $0.10-0.20 \mathrm{~m}$, and $467 \mathrm{~g} \mathrm{~kg}^{-1}$ at $0.20-0.30 \mathrm{~m}$ ), it may explain the shallower root system of the grasses observed in our experiment when compared to that of other authors. In addition, high RD values are commonly associated to the development of plants under suboptimal growing conditions [31], such as that of high PR found in our soil, especially below $0.10 \mathrm{~m}$ depth (Figure 5). The roots of most of the plant species can hardly grow in deep soil depths subjected to high compaction levels [32], 
Monolith I

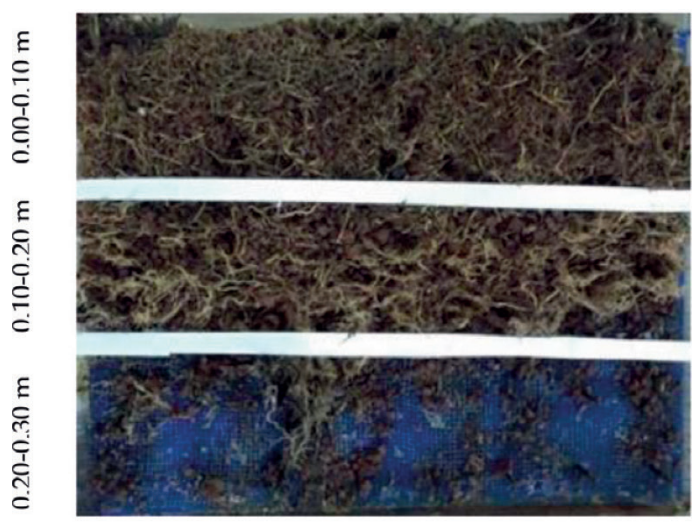

Soil layer: $0.00-0.17 \mathrm{~m}$

Overburden layer: 0.17 - $0.30 \mathrm{~m}$

Monolith III

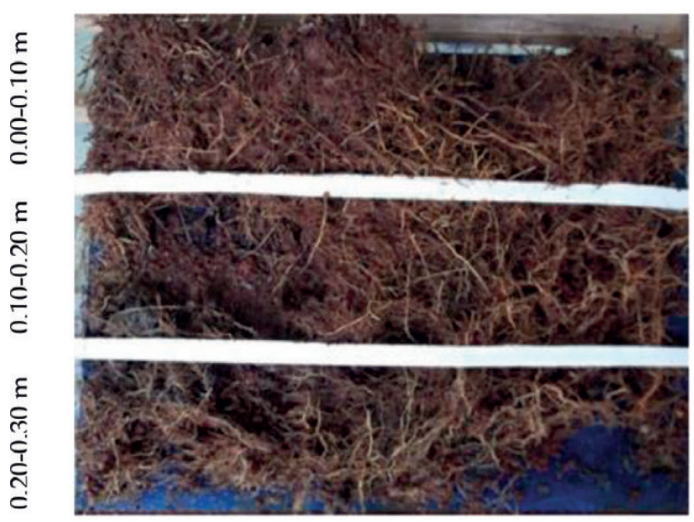

Soil layer: $0.00-0.30 \mathrm{~m}$

Overburden layer: absent
Monolith II

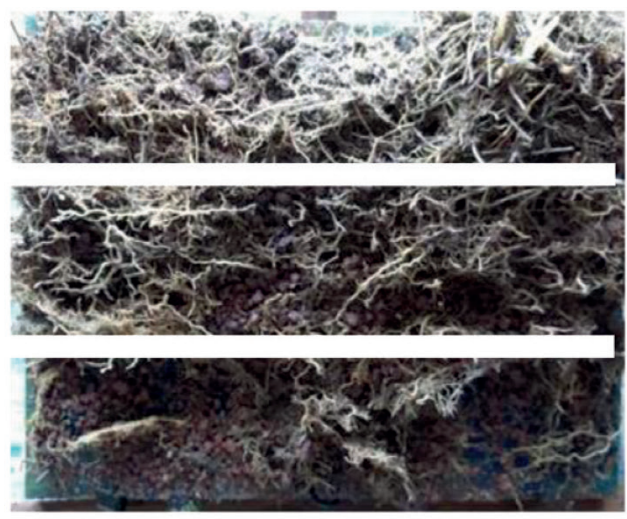

Soil layer: $0.00-0.30 \mathrm{~m}$

Overburden layer: absent

Monolith IV

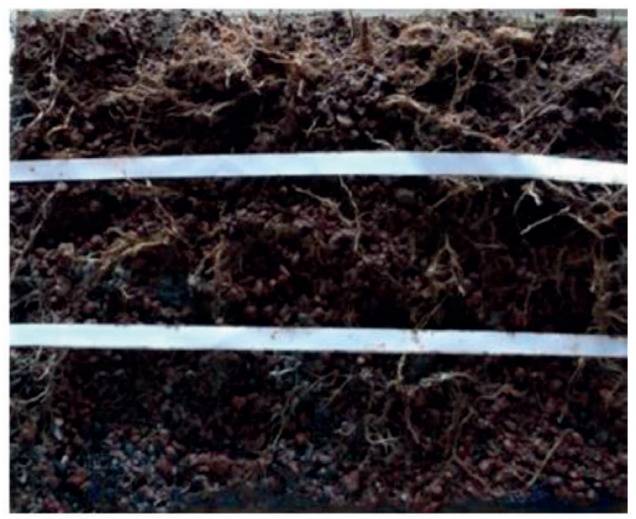

Soil layer: $0.00-0.20 \mathrm{~m}$

Overburden layer: $0.20-0.30 \mathrm{~m}$

Figure 4. Qualitative evaluation of Urochloa brizantha roots after washing of the soil monoliths and soil/overburden distribution within $0.00-0.30 \mathrm{~m}$ layer.

and thus these plants become more susceptible when subjected to extreme climatic events. In agricultural soils, this problem has been reported repeatedly, such as greater concentration of roots of cereals (Eleusine coracana and Pennisetum americanum) observed near the surface of a clayey soil due to the compaction of the subsurface soil layers [33]. These findings corroborate authors that reported the concentration of maize roots (Zea mays) within 0.00-0.07 m layer $(64 \%)$ of an Oxisol [34]. The results were assigned to the physical degradation of the subsurface soil layers, which limited root movement to the lower soil layer.

The main reason for the root thickening in different plant species is related to soil compaction. Deformed and flattened roots [20] as well as thick roots and the concentration of roots near to the soil surface [17] were reported in agricultural soils with compaction problems. In our study, greater proportion of the root system biomass of the grasses, independently on the 


\begin{tabular}{|c|c|c|c|c|c|}
\hline \multirow[t]{2}{*}{ Grasses } & \multirow[t]{2}{*}{ Layer } & \multicolumn{4}{|c|}{$\%$ Layer $^{-1}$} \\
\hline & & RD & RV & RL & RA \\
\hline \multirow[t]{3}{*}{ Hemarthria altissima } & $0.00-0.10 \mathrm{~m}$ & 67.82 & 62.77 & 58.79 & 60.74 \\
\hline & $0.10-0.20 \mathrm{~m}$ & 25.29 & 27.59 & 28.67 & 28.12 \\
\hline & $0.20-0.30 \mathrm{~m}$ & 6.89 & 9.64 & 12.54 & 11.14 \\
\hline \multirow[t]{3}{*}{ Paspalum notatum } & $0.00-0.10 \mathrm{~m}$ & 62.44 & 63.25 & 60.99 & 62.98 \\
\hline & $0.10-0.20 \mathrm{~m}$ & 19.45 & 17.83 & 19.49 & 18.12 \\
\hline & $0.20-0.30 \mathrm{~m}$ & 18.11 & 18.92 & 19.52 & 18.90 \\
\hline \multirow[t]{3}{*}{ Cynodon dactylon } & $0.00-0.10 \mathrm{~m}$ & 61.98 & 53.73 & 51.84 & 53.28 \\
\hline & $0.10-0.20 \mathrm{~m}$ & 29.25 & 36.59 & 33.08 & 34.47 \\
\hline & $0.20-0.30 \mathrm{~m}$ & 8.77 & 9.68 & 15.08 & 12.26 \\
\hline \multirow[t]{3}{*}{ Urochloa brizantha } & $0.00-0.10 \mathrm{~m}$ & 64.72 & 60.91 & 60.12 & 60.42 \\
\hline & $0.10-0.20 \mathrm{~m}$ & 29.24 & 32.56 & 31.59 & 32.14 \\
\hline & $0.20-0.30 \mathrm{~m}$ & 6.04 & 6.53 & 8.29 & 7.44 \\
\hline
\end{tabular}

Table 1. Proportion of root density (RD), root volume (RV), root length (RL), and root area (RA) values of four perennial grasses distributed at $0.00-0.10,0.10-0.20 \mathrm{~m}$, and $0.20-0.30 \mathrm{~m}$ layers of a constructed soil after 103 months of revegetation.

soil layer, was composed of fine roots ( $<0.49 \mathrm{~mm}$ diameter class) (Table 2). Grasses preferably invest in fine roots, but the residence time of the roots in the soil depends on the environmental conditions and on the plant species [35]. In this way, we observed that as Hemarthria altissima, Paspalum notatum, and Cynodon dactylon deepen their root system they proportionally invested more in roots $<0.49 \mathrm{~mm}$ diameter class, while Urochloa brizantha proportionally decreased roots within this same diameter class and slightly invest more in thicker roots (Table 2).

The proportion of roots $>0.50 \mathrm{~mm}$ diameter class was equal or lower than $10 \%$ in all plant species, regardless the soil layer (Table 2). Nevertheless, the proportion of roots within this diameter class along the soil profile increased in Urochloa brizantha and decreased in Hemarthria altissima, Paspalum notatum, and Cynodon dactylon (Table 2).

With respect to the color of the roots, white roots are classified as active, brown roots as senescent and darkened roots as dead [36]. Overall, we observed predominance of brown roots at $0.00-0.10 \mathrm{~m}$ layer, a balance between brown and white roots at $0.10-0.20 \mathrm{~m}$ layer, and predominance of white roots at $0.20-0.30 \mathrm{~m}$ layer, indicating that the plants were able to surpass the highly compacted soil layers, especially at $0.20 \mathrm{~m}$ (Figure 5) and are actively exploring the soil below $0.20 \mathrm{~m}$.

In general, the highest RDM, RV, and RL values were noticed in Urochloa brizantha, mainly within 0.00-0.20 m layer, while the lowest values were observed in Paspalum notatum. Below $0.20 \mathrm{~m}$, differences between the grasses were less pronounced (Figure 6a-c). The inherent vigorous root system of Urochloa brizantha together with its great adaptation to the constructed 


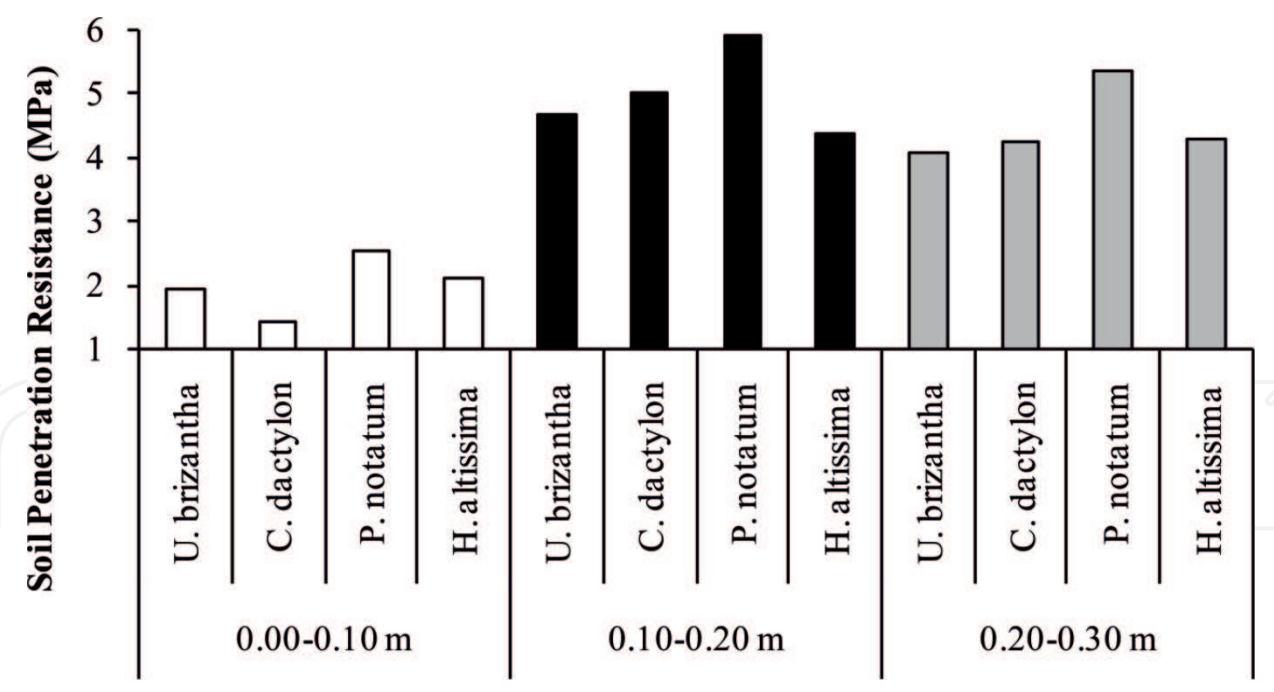

Figure 5. Soil penetration resistance at $0.00-0.10,0.10-0.20 \mathrm{~m}$, and $0.20-0.30 \mathrm{~m}$ layers of a constructed soil after $103 \mathrm{months}$ of revegetation with four perennial grasses.

soil as observed in the present study may have boosted the potential of this species to promote the amelioration of soil physical attributes as reported in a previous work [37].

The roots tend to occupy very low proportions of the soil volume, less than $1 \%$ of the arable layer [38]. At 0.00-0.20 m layer, the soil volume occupied by the roots of the grasses decreased

\begin{tabular}{llll}
\hline Grasses & Layer & \multicolumn{2}{l}{ \% of roots in diameter classes } \\
\hline Hemarthria altissima & & $<0.49 \mathbf{~ m m}$ & $>\mathbf{0 . 5 0 ~} \mathbf{~ m m}$ \\
\hline Paspalum notatum & $0.00-0.10 \mathrm{~m}$ & 90.93 & 9.07 \\
& $0.10-0.20 \mathrm{~m}$ & 91.22 & 8.78 \\
& $0.20-0.30 \mathrm{~m}$ & 93.51 & 6.49 \\
\hline Cynodon dactylon & $0.00-0.10 \mathrm{~m}$ & 90.11 & 9.89 \\
& $0.10-0.20 \mathrm{~m}$ & 91.01 & 8.99 \\
\hline & $0.20-0.30 \mathrm{~m}$ & 92.32 & 7.68 \\
\hline & $0.00-0.10 \mathrm{~m}$ & 91.87 & 8.13 \\
\hline & $0.10-0.20 \mathrm{~m}$ & 92.24 & 7.76 \\
\hline & $0.20-0.30 \mathrm{~m}$ & 96.01 & 3.99 \\
\hline
\end{tabular}

Table 2. Perennial grass roots distribution in diameter classes at $0.00-0.10,0.10-0.20 \mathrm{~m}$, and $0.20-0.30 \mathrm{~m}$ layers of a constructed soil after 103 months of revegetation. 
a)

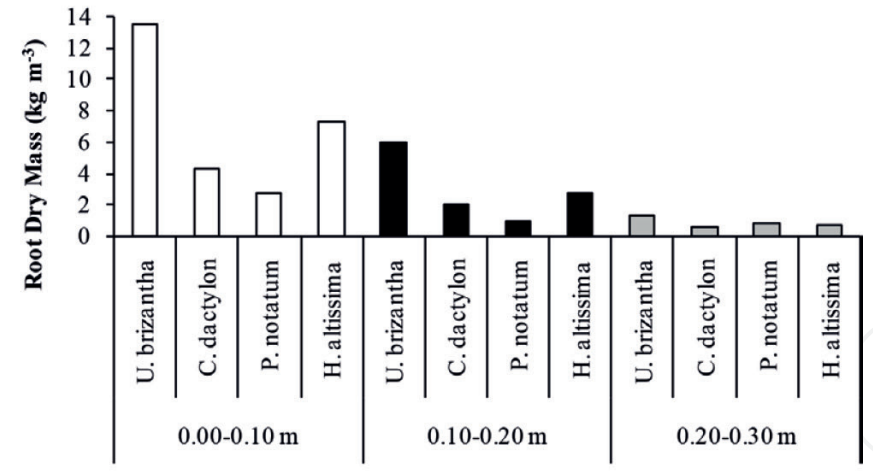

b)

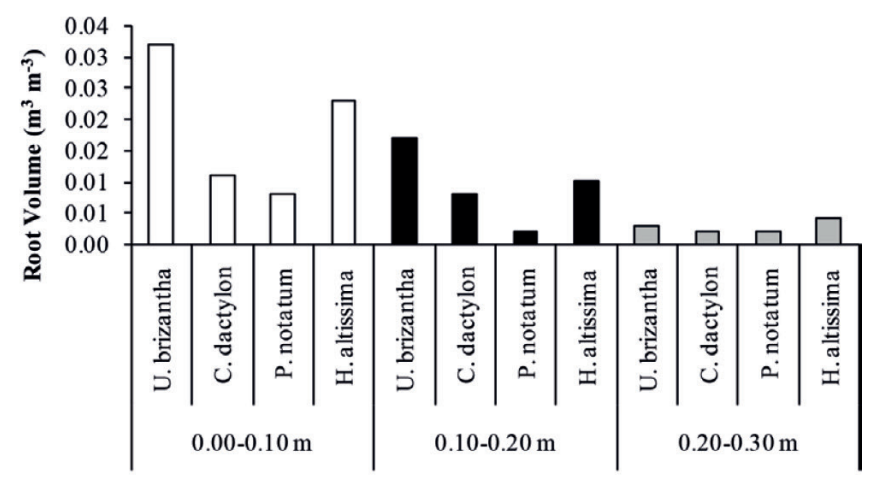

c)

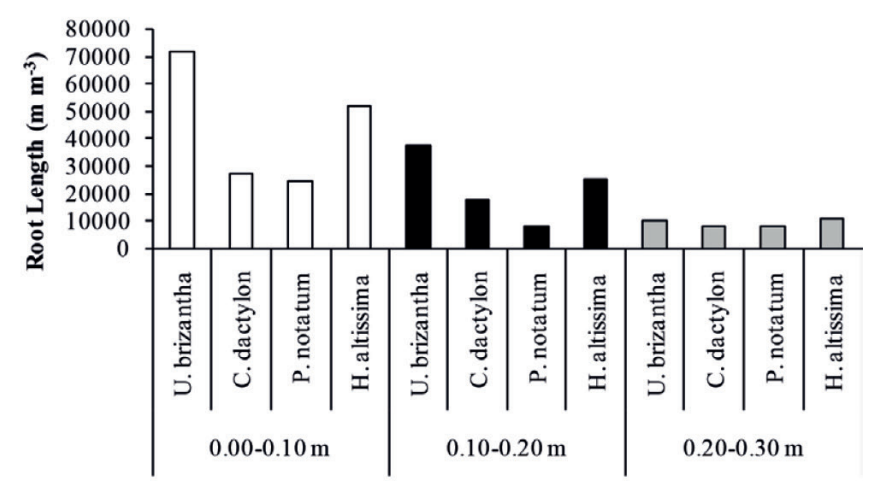

d)

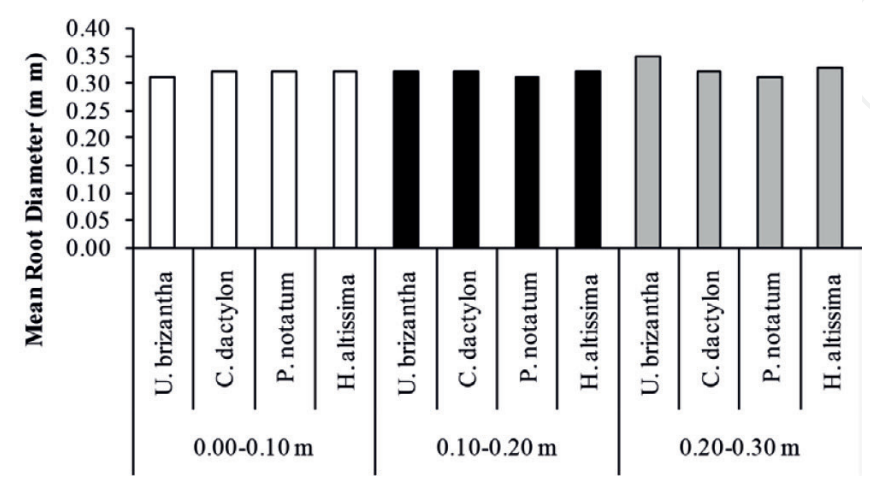

Figure 6. Root dry mass (a), root volume (b), root length (c), and root diameter (d) of four perennial grasses at 0.00-00.10, $0.10-0.20$, and $0.20-0.30 \mathrm{~m}$ depth of a constructed soil after 103 months of revegetation. 
as follows: Urochloa brizantha, 2.45\%; Hemarthria altissima, 1.65\%; Cynodon dactylon, 0.95\%; and Paspalum notatum, $0.50 \%$ (Figure 6b). Additionally, it is important to give attention to the high RV of Urochloa brizantha at $0.00-0.10 \mathrm{~m}$ layer, $3.2 \%$.

Combining the data of Figures 5 and $\mathbf{6}$, the effect of the soil PR on the roots of the grasses can be highlighted as:

a. Hemarthria altissima-when PR increased $107 \%$, from 2.12 to $4.39 \mathrm{MPa}$, RV and RL were decreased by 56.5 and $51.2 \%$, respectively;

b. Paspalum notatum-when PR increased $135 \%$, from $2.52 \mathrm{MPa}$ to $5.92 \mathrm{MPa}$, RV and RL were decreased by 75.0 and $68.0 \%$, respectively;

c. Cynodon dactylon-when PR increased $256 \%$, from 1.41 to $5.04 \mathrm{MPa}$, RV and RL were decreased by 27.3 and $36.2 \%$, respectively;

d. Urochloa brizantha - when PR increased 143\%, from 1.92 to $4.66 \mathrm{MPa}$, RV and RL were decreased by 46.9 and $47.5 \%$, respectively.

The data above reveal the ability of Cynodon dactylon to tolerate highly compacted soil conditions. At the same time that this species was subjected to the highest proportional increase in PR, it was less sensible than the other species with regard to RV and RL. However, the PR below $0.10 \mathrm{~m}$ depth is expected to decrease more consistently over time, as the roots disrupt the compacted layer, similarly to what is observed in agricultural soils under conservation tillage systems, for example, no tillage [39].

Similar MRD was observed for all grasses, ranging from 0.31 to $035 \mathrm{~mm}$ (Figure 6d). However, along the soil profile, the MRD of the plant species behaved differently. The MRD of Hemarthria altissima and particularly that of Urochloa brizantha increased in depth, while the MRD of Cynodon dactylon and Paspalum notatum was constant or decreased along the soil profile, respectively (Figure 6d). Although the root thickening is generally associated to unfavorable soil compaction conditions, at the same time, it indicates the adaptation of Urochloa brizantha and Hemarthria altissima to the dramatic conditions of the constructed soil. In fact, the RV, RL, and RDM values of these species were superior than that of the other species, not only near to the soil surface where growing conditions are more reasonable, but also below $0.10 \mathrm{~m}$ depth in general (Figure 6a-c). In this way, we can expect that the soil physical attributes of subsurface soil layers will be improved more rapidly by Hemarthria altissima and Urochloa brizantha than by Paspalum notatum and Cynodon dactylon.

\section{Conclusions}

After surface coal mining, construction of the soil and its revegetation with perennial grasses for 103 months, we conclude that:

1. The root system of all grasses was markedly concentrated within $0.00-0.10$ m layer, most probably due to impeditive physical conditions of the soil below $0.10 \mathrm{~m}$. 
2. The qualitative analysis of the soil monoliths evidenced that the plants explored the soil below $0.10 \mathrm{~m}$ depth via fine and flattened roots mainly, which penetrated through the cracks of the compacted soil layer.

3. Regardless the soil layer, the roots of all grass species were predominantly $<0.49 \mathrm{~mm}$ diameter class, classified as very fine roots. However, below $0.10 \mathrm{~m}$ depth, Urochloa brizantha increased the proportion of roots $>0.50 \mathrm{~mm}$ diameter class, while Hemarthria altissima, Paspalum notatum, and Cynodon dactylon rather increased the proportion of roots $<0.49 \mathrm{~mm}$ diameter class.

4. The root system of Urochloa brizantha developed more consistently along the soil profile compared to the other species, indicating the greater potential of this species to surpass compacted layers and moreover to improve soil physical attributes not only above $0.10 \mathrm{~m}$ but also below $0.10 \mathrm{~m}$ as well, where soil conditions are more critical.

5. Once the roots of the plant species tested in this work can potentially reach deep depths and overburden layers, the recommendation of these species to the reclamation of soils constructed after coal mining should consider the thickness of the topsoil used to cover the overburden and the presence of pyrite in order to avoid acid drainage.

\section{Acknowledgements}

To Companhia Riograndense de Mineração (CRM), Brazilian Coal Network, CAPES e CNPq for logistical and financial support.

Dr. Leal thanks Alexander von Humboldt Foundation for the "Return Fellowship" provided which supported this work.

\section{Conflict of interest}

The manuscript is original, has not been published before, and is not being considered for publication elsewhere in its final form neither in printed nor in electronic format and does not present any kind of conflict of interests. The publication has been approved by all coauthors as well as by the responsible authorities at the institute where the work has been carried out.

\section{Author details}

Lizete Stumpf ${ }^{1 *}$, Otávio dos Anjos Leal ${ }^{2}$, Eloy Antonio Pauletto ${ }^{1}$ and Luiz Fernando Spinelli Pinto ${ }^{1}$

*Address all correspondence to: zete.stumpf@gmail.com

1 Federal University of Pelotas, Pelotas, Rio Grande do Sul, Brazil

2 Federal University of Santa Maria, Santa Maria, Rio Grande do Sul, Brazil 


\section{References}

[1] CGEE-Centro de Gestão e Estudos Estratégicos. Roadmap tecnológico para produção, uso limpo e eficiente do carvão mineral nacional: 2012 a 2035 [Internet]. 2013. Available from: www.cgee.org.br/atividades/redirect/7877 [Accessed: March 20, 2018]

[2] DNPM - Departamento Nacional de Produção Mineral. Carvão Mineral [Internet]. 2013. Available from: http://www.dnpm.gov.br/dnpm/sumarios/carvao-mineralsumariomineral-2014/view [Accessed: March 20, 2018]

[3] CPRM-Serviço Geológico do Brasil [Internet]. 2014. Available from: http://www.cprm. gov.br/publique/cgi/cgilua.exe/sys/start.htm?sid=59 [Accessed: March 20, 2018]

[4] Leal OA, Castilhos RMV, Pauletto EA, Pinto LFS, Pillon CN, Penning LH, Santos DC. Organic matter fractions and quality of the surface layer of a constructed and vegetated soil after coal mining II-Physical compartments and carbon management index. Revista Brasileira de Ciência do Solo. 2015;39:895-902. DOI: 10.1590/01000683rbcs20140784

[5] Stumpf L, Leal OA, Pauletto EA, Pinto LFS, Reis DA, Pinto MAB, Tuchtenhagen IK. Tensile strength and organic matter fractions in aggregates of a grass-covered mined soil under early stage recovery. Soil and Tillage Research. 2018;176:69-76. DOI: 10.1016/j. still.2017.11.006

[6] Mukhopadhyay S, Maiti SK, Masto RE. Development of mine soil quality index (MSQI) for evaluation of reclamation success: A chronosequence study. Ecological Engineering. 2014;71:10-20. DOI: 10.1016/j.ecoleng.2014.07.001

[7] Borůvka L, Kozák J, Mühlhanselová M, Donátová H, Nikodem A, Němeček K. Effect of covering with natural topsoil as a reclamation measure on brown-coal mining dumpsites. Journal of Geochemical Exploration. 2012;113:118-123. DOI: 10.1016/j.gexplo.2011.11.004

[8] Zhao Z, Shahrour I, Bai Z, Fan W, Feng L, Li H. Soils development in opencast coal mine spoils reclaimed for 1-13 years in the West-Northern Loess Plateau of China. European Journal of Soil Biology. 2013;55:40-46. DOI: 10.1016/j.ejsobi.2012.08.006

[9] Wick AF, Daniels WL, Nash WL, Burger JA. Soil aggregation, organic matter and microbial dynamics under different amendments after 27 years of mine soil development. In: National Meeting of the American Society of Mining and Reclamation; 5-11 June 2010; Pittsburgh. Lexington: ASMR; 2010. pp. 364-1386

[10] Thomas KA, Sencindiver JC, Skousen JG, Gorman JM. Soil horizon development on mountaintop surface mine in Southern West Virginia. Green Lands. 2000;30:41-52

[11] Onweremadu EU. Chronosequential pedon development on a mined landscape. Journal of American Science. 2007;3:16-22 
[12] Akala VA, Lal R. Soil organic carbon pools and sequestration rates in reclaimed minesoils in Ohio. Journal Environmental Quality. 2001;30:2098-2104. DOI: 10.2134/jeq2001.2098

[13] Krümmelbein J, Raab T. Development of soil physical parameters in agricultural reclamation after brown coal mining within the first four years. Soil and Tillage Research. 2012;125:109-115. DOI: 10.1016/j.still.2012.06.013

[14] Stumpf L, Pauletto EA, Pinto LFS. Soil aggregation and root growth of perennial grasses in a constructed clay minesoil. Soil and Tillage Research. 2016;161:171-178. DOI: 10.1016/j. still.2016.03.005

[15] Lima VMP, Oliveira GC, Serafim NE, Curi N, Evangelista AR. Intervalo hídrico ótimo como indicador de melhoria da qualidade estrutural de Latossolo degradado. Revista Brasileira de Ciência do Solo. 2012;36:71-78. DOI: 10.1590/S0100-06832012000100008

[16] Debiasi H, Levien R, Trein CR, Conte O, Mazurana M. Capacidade de suporte e compressibilidade de um Argissolo influenciadas pelo tráfego e por plantas de cobertura de inverno. Revista Brasileira de Ciência do Solo. 2008;32:2629-2637. DOI: 10.1590/S01001802/180214066004

[17] Reinert DJ, Albuquerque JÁ, Reichert JM, Aita C, Andrada MMC. Limites críticos de densidade do solo para o crescimento de raízes de plantas de cobertura em Argissolo Vermelho. Revista Brasileira de Ciência do Solo. 2008;32:1805-1816. DOI: 10.1590/S010006832008000500002

[18] Silva IF, Mielniczuk J. Ação do sistema radicular de plantas na formação e estabilização de agregados do solo. Revista Brasileira de Ciência do Solo. 1997;20:113-117

[19] Ralisch R, Almeida E, Silva AP, Pereira Neto OC, Guimarães MF. Morphostructural characterization of soil conventionally tilled with mechanized and animal traction with and without cover crop. Revista Brasileira de Ciência do Solo. 2010;34:1795-1802. DOI: 10.1590/S0100-06832010000600003

[20] Costa F, Paciomik S, Abreu JBR. Distribuição vertical de características morfológicas do sistema radicular de Brachiaria humidicola. Pastures Tropicales. 2000;24:14-20

[21] IUSS-WORKING GROUP WRB. World Reference Base for Soil Resources 2014. International Soil Classification System or Naming Soils Creating Legends for Soils Maps FAO, Rome (World soil resources reports, 106). 2015

[22] Leal OA, Castilhos RMV, Pinto LFS, Pauletto EA, Lemes ES, Kunde RJ. Initial recovery of organic matter of a grass-covered constructed soil after coal mining. Revista Brasileira de Ciência do Solo. 2016;40:1-16. DOI: 10.1590/18069657rbcs20150384

[23] Böhm W. Methods of Studying Root Systems Ecological Studies. Vol. 33. New York: Springer-Verlag; 1979. 183p 
[24] Jorge LA, Crestana S. Processamento de imagens em ciência do solo: raízes, morfologia e cobertura do solo. In: Martin neto L, Vaz CMP, Crestana S, editors. Instrumentação avançada em ciência do solo. São Paulo: Embrapa Instrumentação Agropecuária; 2007. pp. 341-438

[25] Stolf R. Teoria e teste experimental de fórmulas de transformação dos dados de penetrômetro de impacto em resistência do solo. Revista Brasileira de Ciência do Solo. 1991;15:229-235

[26] Johnson DB, Hallberg KB. Biogeochemistry of the compost bioreactor components of a composite acid mine drainage passive remediation system. Science of the Total Environment. 2005;338:81-93. DOI: 10.1016/j.scitotenv.2004.09.008

[27] Libardi LL, Van Lier Q. Atuação dos fatores físicos do solo no desenvolvimento do sistema radicular. In: Workshop sobre sistema radicular: metodologias e estudo de casos; 15-17 November 1999; Aracajú: EMBRAPA - Tabuleiros Costeiros; 1999. pp. 47-56

[28] Jackson RB, Canadel J, Ehleringer JR, Mooney HA, Sala OE, Schulze ED. A global analysis of root distributions for terrestrial biomes. Oceologia. 1996;108:389-411. DOI: 10.1007/ BF00333714

[29] Peek MS, Leffler AJ, Ivans CY, Ryel RJ, Caldwell MM. Fine root distribution and persistence under field conditions of three co-occurring Great Basin species of different life form. New Phytology. 2005;165:171-180. DOI: 10.1111/j.1469-8137.2004.01186.x

[30] Schenk HJ, Jackson RB. Rooting depths, lateral root spreads, and belowground/aboveground allometries of plants in water limited ecosystems. Journal of Ecology. 2002;90: 480-494. DOI: 10.1046/j.1365-2745.2002.00682.x

[31] Fontoura RC. Variação estacional de atributos funcionais de Paspalum notatum em diferentes níveis de fertilidade do solo [thesis]. Porto Alegre: Universidade Federal do Rio Grande do Sul; 2014

[32] Sheoran V, Sheoran AS, Poonia P. Soil reclamation of abandoned mine land by revegetation: A review. International Journal of Soil, Sediment and Water. 2010;3:2-13

[33] Gonçalves WG, Jimenez RL, Araújo Filho JV, Assis RL, Silva GP, Pires FR. Sistema radicular de plantas de cobertura sob compactação do solo. Engenharia Agrícola. 2006;26: 67-75. DOI: 10.1590/S0100-69162006000100008

[34] Nunes MR. Mitigação da compactação do solo em plantio direto $125 \mathrm{f}$ Dissertação (Mestrado em Agronomia). Universidade Federal de Pelotas; 2014

[35] Hendrick RL, Pregitzer KS. The dynamics of fine root length, biomass, and nitrogen content in two northern hardwood ecosystems. Canadian Journal of Forest Research. 1993;23:2507-2520. DOI: 10.1139/x93-312

[36] Comas LH, Eissenstat DM, Lakso AN. Assessing root death and root system dynamics in a study of grape canopy pruning. New Phytologist. 2000;147:171-178 
[37] Stumpf L, Pauletto EA, Fernandes FF, Suzuki LEAS, Silva TS, Pinto LFS, Lima CLR. Perennial grasses for recovery of the aggregation capacity of a reconstructed soil in a coal mining area in southern Brazil. Revista Brasileira de Ciência do Solo. 2014;38:327-335. DOI: 10.1590/S0100-06832014000100033

[38] Anghinoni I, Meurer EJ. Eficiência de absorção de nutrientes pelas raízes. In: Workshop sobre sistema radicular: metodologias e estudo de casos; 15-17 November 1999; Aracajú: EMBRAPA - Tabuleiros Costeiros; 1999. pp. 57-87

[39] Ralisch R, Miranda TM, Okumura RS, Barbosa GM, Guimarães MF, Scopel E, Balbino LC. Resistência à penetração de um Latossolo Vermelho-Amarelo do Cerrado sob diferentes sistemas de manejo. Revista Brasileira de Engenharia Agrícola e Ambiental. 2008;12:381-384. DOI: 10.1590/S1415-43662008000400008 

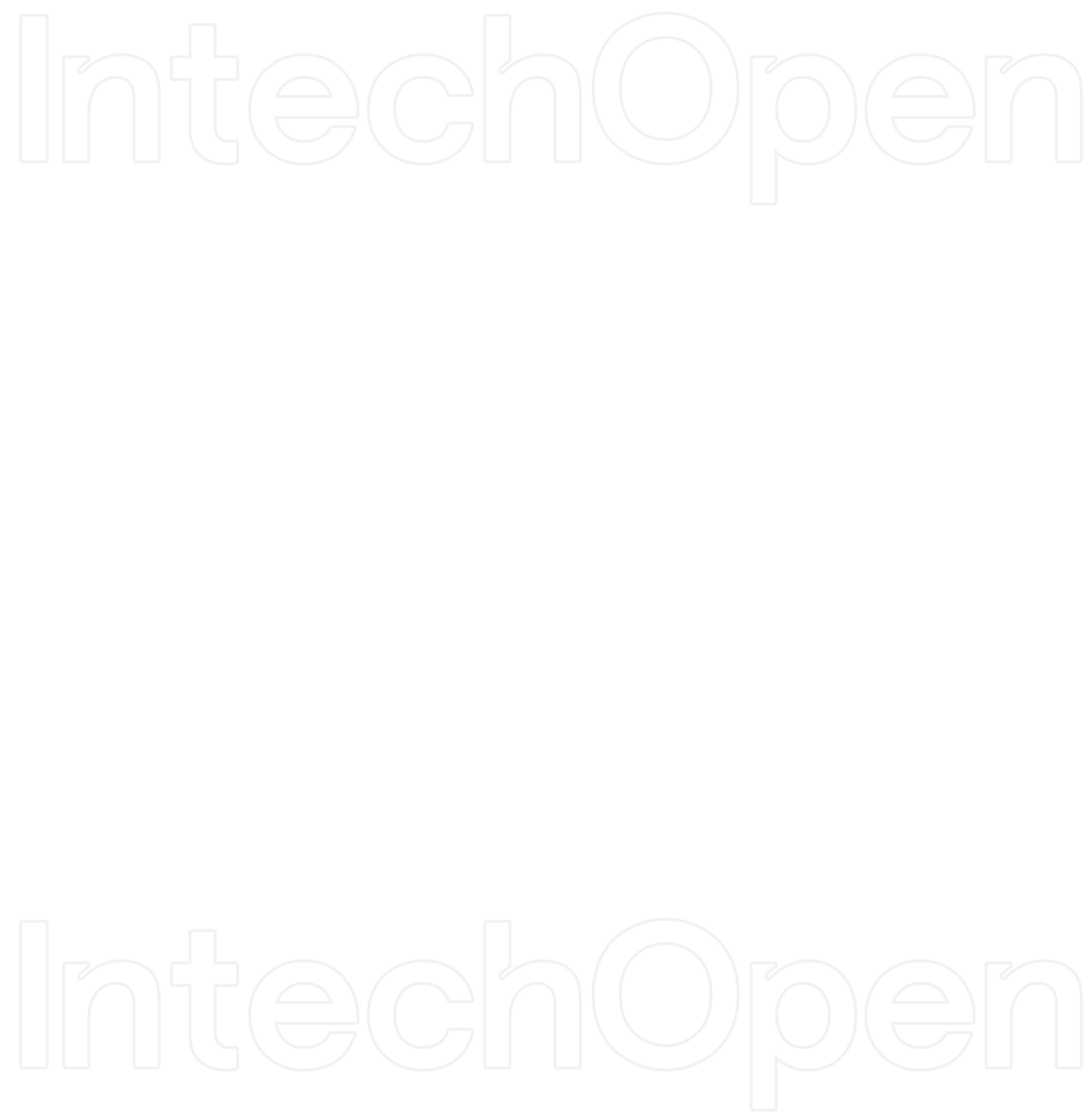


\title{
Presowing with Bacteria Improved the Productivity and Resistance to Fungal Root Pathogen in Wheat and Barley
}

\author{
Natalia Tereshchenko, Elena Akimova, \\ Oksana Minaeva, Alexandra Kravets and \\ Tatyana Zyubanova
}

Additional information is available at the end of the chapter

http://dx.doi.org/10.5772/intechopen.80084

\begin{abstract}
It is well known that reducing the extent of damage to grain crops by root rot causing agents is one of the most effective ways to increase the yield of agricultural grain crops and improve their quality. These diseases are especially harmful for hard wheat, barley, soft spring wheat, and winter rye. Yield losses due to these diseases may reach $19-20 \%$ or more for wheat and $25-30 \%$ or more for barley. In order to assess the effectiveness of the bacteria isolated from earthworm coprolites as biological control agents, we conducted a series of field tests in Western Siberia from 2011 to 2015. We compared growth and development indicators of spring wheat (Triticum aestivum L., Irgina variety) and barley (Hordeum vulgare L., Acha variety) where seeds were treated with Bacillus cereus and two strains of Pseudomonas. The results showed that the inoculation increased the grain yield by $0.2-1.0 \mathrm{t} \mathrm{ha}^{-1}$ for spring wheat and by $0.3-1.8 \mathrm{t} \mathrm{ha}^{-1}$ for barley. In addition, the prevalence of the disease in spring wheat plants was significantly reduced from $18.1-61.1 \%$ in the control plots to $6.4-50.2 \%$ in the inoculated plots. Similarly, the index of root rot development decreased from $18.2-23.0 \%$ in the control plots to $13.2-15.8 \%$ in the inoculated plots. To understand the mechanism that induces the spring wheat resistance to fungal root rots under the influence of rhizobacteria, we investigated the effect on the guaiacol-dependent peroxidase activity. There was an inverse relationship between the peroxidase activity in wheat tissues and damage of plants caused by root rot agents indicating that the response of peroxidase enzymes to plant inoculation is a meaningful indicator that can be used to assess the potential of a particular strain as a biological agent for protecting spring wheat.
\end{abstract}

Keywords: bacteria inoculation, barley, Bipolaris sorokiniana, Hordeum vulgare, peroxidase, root rot, Triticum aestivum, wheat 


\section{Introduction}

It is well known that in soil and climatic conditions of the West Siberian region, reducing the extent of damage to grain crops by root rot causing agents is one of the most effective ways to increase the yield of agricultural grain crops and improve their quality. Unstable weather factors, high probability of spring frosts, high humidity, and heavy soil texture create the most favorable conditions for the rapid development of root rots caused by soil phytopathogenic fungi. A review of literature data [1] and results of annual phytosanitary inspections of grain plantings by responsible federal services indicates that the most destructive diseases of grain crops in the West Siberian region are root rots caused by Bipolaris sorokiniana (Sacc.) Shoemaker and Fusarium oxysporum Schlecht. These diseases are especially harmful for hard wheat, barley, soft spring wheat, and winter rye. Yield losses due to the diseases may reach $19-20 \%$ or more for wheat and $25-30 \%$ or more for barley $[2,3]$.

The concept of "high farming culture" implies not only scientifically based and environmentfriendly application of chemical fertilizers and pesticides, but also their partial replacement with biological preparations with a similar spectrum of action. Therefore, the development and use of biological preparations for plant protection is one of the key priorities of modern agrobiotechnology. Search for new strains of antagonistic bacteria that can be effectively used as biological control agents and research of antifungal mechanisms of the bacteria are both important tasks.

Long-term studies of microbiological aspects of vermiculture demonstrate that the percentage of Pseudomonas and Bacillus bacteria significantly increases in the microbial community of earthworm coprolites. These bacteria are known to be one of the most active producers of plant growth stimulants and, at the same time, antagonists of lower soil fungi. Also, the studies show an increased antifungal activity of the bacteria isolated from coprolites of Eisenia fetida worms compared to the strains isolated from the original organic substrate [4].

Many rhizosphere bacteria are well known to have fungistatic properties, since this feature provides bacteria with a significant trophic advantage when growing on substrates populated with a mixed (bacterial and fungal) flora. There are a number of mechanisms through which bacteria inhibit the growth of lower soil fungi, for example, competition for nutrients and production of siderophores, antibiotics, enzymes, and a number of other compounds [5-8].

A number of studies also indicate that growth-stimulating and antifungal activities of the bacteria in vitro usually positively correlate with the metabolic activity of bacteria in field experiments $[5,9,10]$. However, there is also abundant evidence that the metabolic activity of the bacteria revealed in the laboratory conditions cannot always be reproduced in practical application of the biological preparations based on them [11, 12]. In order to assess the effectiveness of the bacteria isolated from earthworm coprolites as biological control agents, we conducted a series of field tests from 2011 to 2015. 


\section{Materials and methods}

\subsection{Materials}

The main objects of our research were spring wheat (Triticum aestivum L., Irgina variety) and spring barley (Hordeum vulgare L., Acha variety). We compared growth and development indicators of spring wheat plants and barley whose seeds were treated with enrichment cultures of microbial strains with a titer of $10^{6}-10^{7}$ cells per $1 \mathrm{ml}$. In this experiment, one Bacillus cereus strain and two Pseudomonas (Ps.sp.GS4 and Ps.sp.PhS1) strains were tested. Bacterial strains were isolated from coprolites of earthworms Eisenia fetida. All strains are producers of plant growth stimulants. In addition, one of the strains (PhS1) is capable of phosphate mobilization. Bacterial preparations were used at a dose of $100 \mathrm{ml} / 10 \mathrm{~kg}$ of grain. Seeding rates were 6.5 million seeds per hectare for wheat and 5.5 million seeds per hectare for barley. Bacteria were used both as a monoculture of each strain (separately) and as a mixed culture of all the three strains.

\subsection{Field experiments}

Field experiments were conducted on gray podzolic medium-loamy soil with the following physical and chemical properties: $\mathrm{pH}-5.0$; humus content $-4.87 \%$; total absorbed bases$24.9 \mathrm{mg}$ per $100 \mathrm{~g}$ of soil on a dry weight basis; and $\mathrm{N}-\mathrm{NH}_{4^{\prime}} \mathrm{N}-\mathrm{NO}_{3^{\prime}} \mathrm{P}_{2} \mathrm{O}_{5}$, and $\mathrm{K}_{2} \mathrm{O}-2.66,8.48$, 236.5 , and $99.2 \mathrm{mg} / \mathrm{kg}$ dry weight of soil on a dry weight basis, respectively. Each experiment was repeated three times in all years of the tests. The variants were arranged in a systematic way. The total area of the plot was $40 \mathrm{~m}^{2}$. The area of the record plot was $32 \mathrm{~m}^{2}$. In order to optimize the mineral background, mineral fertilizers were applied to the soil at a dose of $\mathrm{N}_{45} \mathrm{P}_{30} \mathrm{~K}_{30}$. The effectiveness of bacterial application was assessed in terms of field germination, some morphometric parameters of plants (height and green mass of plants), content of photosynthetic pigments in leaves, the extent of damage caused by root rot causing agents, as well as grain yield, yield structure, and grain quality. Morphometric parameters of the plants were taken into account in the flowering stage, and the extent of disease damage in the tillering and early flowering stage. The total protein content in the grain was determined with an Infrared FT-10 IR spectrometer. In order to determine the content of photosynthetic pigments in the leaves in the flowering stage, we analyzed alcohol extracts from the leaves with a UV-1601 SHIMADZU spectrophotometer at wavelengths of 665,649 , and $440.5 \mathrm{~nm}$, and then made calculations using the Vernon formula [13]. The statistical validity of the estimated effects was tested by the Student's test and the nonparametric Mann-Whitney test using Statistica 10.0 for Windows.

\subsection{Weather and soil conditions}

Throughout the field test period, there were significant fluctuations in temperature and precipitation. While the growing season of 2011 could be described as moderately warm and humid, the season of 2012 in the south of Western Siberia was characterized by extremely 
unfavorable weather conditions: June was abnormally hot, with precipitation of $48 \%$ below normal. The average monthly air temperature was $5.3^{\circ} \mathrm{C}$ above normal. The topsoil under spring grain crops was insufficiently moistened (5-22 $\mathrm{mm})$. High temperatures and lack of moisture caused the accelerated development of grain crops at different stages. The weather conditions in the growing season of 2013 were not sufficiently favorable for the growth and development of crops as well. The beginning and end of the growing season were characterized by low temperatures with frequent and heavy precipitation, while late July and early August were hot and dry. The early growing season both in 2013 and 2014 was characterized by unfavorable weather conditions for field work, growth, and development of crops: cold May and early June with frequent and heavy precipitation. The weather conditions of the entire growing period of 2015 were relatively favorable, with high total precipitation between April and September, above-normal precipitation in May, July, August, and September, and a short dry period in June.

\subsection{Inoculation study in model experiments}

The model experiments were based on a liquid 24-hour culture of the bacteria grown in $250 \mathrm{ml}$ flasks with $100 \mathrm{ml}$ of GRM broth at $+28 \ldots+29^{\circ} \mathrm{C}$ to a titer of $1-9 \times 10^{9}$ cells $/ \mathrm{ml}$. The experiments were carried out in laboratory conditions. We studied the effect of seed inoculation on the peroxidase activity in the presence of phytopathogen using a model of the simplest terrestrial ecosystem consisting of four links: sand-host plant-bacterial strain-phytopathogenic fungus [12]. Seeds pretreated for $3 \mathrm{~min}$ with $70 \%$ ethanol were washed with sterile water and germinated in a wet chamber at $+18 \ldots+20^{\circ} \mathrm{C}$. After the appearance of a germ $(1 \mathrm{~mm})$, the seeds were inoculated with suspensions of the experimental strains for $20 \mathrm{~min}$ at the rate of $10^{4}$ cells per seed. In the control variant, the seeds were soaked in distilled water. After treatment, the seeds were placed in plastic containers $(1200 \mathrm{ml}, 45$ seeds per container) filled with coarse sterile river sand $(800 \mathrm{ml})$, and evenly moistened with a sterile Knop's solution for hydroponic and sandy cultures: $\mathrm{Ca}\left(\mathrm{NO}_{3}\right)_{2}-1.0 \mathrm{~g} / \mathrm{l}, \mathrm{KH}_{2} \mathrm{PO}_{4}-0.25 \mathrm{~g} / \mathrm{l}, \mathrm{MgSO}_{4} \times 7 \mathrm{H}_{2} \mathrm{O}-0.125 \mathrm{~g} / \mathrm{l}$, $\mathrm{KNO}_{3}-0.25 \mathrm{~g} / \mathrm{l}, \mathrm{FeCl}_{3}-0.012 \mathrm{~g} / \mathrm{l}$.

In order to create infection background, we used agar strips with a 6-day mycelium of Bipolaris sorokiniana (Sacc.) Shoemaker, grown on potato-glucose agar at $+22 \ldots+24^{\circ} \mathrm{C}$. This micromycete is a common agent of root rots in grain crops. The B. sorokiniana culture was provided by employees of the Faculty of Agronomy of the Novosibirsk State Agrarian University. The agar strips with the fungus mycelium were placed in rows with the plant seeds and embedded in the sand.

\subsection{Model experiment in growth chamber}

The plants were grown in an environmental chamber (Growth Chamber GLK-300, Korea) under fluorescent lamps with an illumination intensity of $12 \mathrm{klux}\left(200 \mu \mathrm{mol}\right.$ quanta/ $\mathrm{m}^{2} \times \mathrm{sec}$, PAR) with a 16 -hour photoperiod at $+18 \ldots+20^{\circ} \mathrm{C}$ (daytime temperature),$+14 \ldots+16^{\circ} \mathrm{C}$ (nighttime temperature), and $75 \%$ humidity. The total duration of the experiments was 12 days. At the end of the experiment, the germination capacity, plant length, peroxidase activity in the leaves and roots of the plants, as well as the prevalence of the disease and index of root rot development (disease index) were determined [14]. 
The guaiacol-dependent peroxidase activity was determined spectrophotometrically in the total protein extract (centrifugate) produced from wheat leaves and roots (concentration in the hydrogen peroxide reaction mixture $-7.35 \mathrm{mM}$ and guaiacol $-0.672 \mathrm{mM}$ ). The enzyme activity was calculated by the Boyarkin's method [15], taking into account the molar extinction coefficient of tetraguaiacol and expressed in $\mathrm{mM}$ of guaiacol/( $\mathrm{min} \times \mathrm{g}$ of fresh weight).

\section{Results and discussion}

\subsection{Effects on morphology of plants}

The results of field experiments for different years show that the inoculation usually stimulates the growth of wheat and barley plants, which is expressed in the accelerated development at main plant development stages and a statistically significant increase in the basic morphometric parameters of plants, such as height, the number of productive stems, the number of leaves, as well as the dry green mass compared to the control variant (non-inoculated plants treated with water before planting).

In different years, the height of wheat and barley plants increased, respectively, by $8-14 \%$ and $6-40 \%$ under the influence of bacteria monocultures and by $6-16 \%$ and $5-20 \%$, respectively, under the influence of complex inoculation. On average over all years, the flag leaf area of wheat increased by $5-6 \%$, while the sub-flag leaf area of barley increased by $5-15 \%$. On average over all years, the dry mass of wheat and barley plants increased, respectively, by $10-40 \%$ and $15-73 \%$, for monoculture variants, and by $7-54 \%$ and $23-63 \%$ for the variants with complex inoculation. In general, the plants responded to the inoculation by increasing not so much their length as their green mass, which contributed to an increase in the stem thickness and, therefore, indicated an increased lodging resistance of the plants.

The analysis of the moisture content in the green mass of wheat and barley shows that the water content of the inoculated plants tends to be higher compared to the control plants, which suggests a positive effect of the bacteria on the development of the root system. Rhizobacteria are known to be capable of controlling parameters of the root system by producing a wide range of hormone-like metabolites. Therefore, they contribute to an increase in length of both main and lateral roots, thereby increasing the catchment area [16].

These physiological effects are especially important in the context of the recent climate changes that increase the risk of extreme weather events (sudden changes in air temperature and humidity, increased dry periods during vegetation, etc.). It was no coincidence that the positive effects from the inoculation of spring grain crops were most noticeable in 2012-the year marked by an extremely dry summer period. The moisture content in the inoculated wheat plants was significantly $(8-10 \%)$ higher than that of the control plants. Notably, the differences with the control variant are most noticeable at the flowering and tillering stages where the need of spring wheat for soil moisture is maximal and the water consumption makes up $50-60 \%$ of the total water consumption for the entire growing season. 
For barley, the differences with the control variant are also most noticeable at the tillering (booting) stage when this crop has the maximum need for soil moisture. The root system of the inoculated barley plants absorbed $18.5-28.4 \%$ more moisture compared to the control plants. Lack of soil moisture in this period is known to lead to an increased number of sterile spikelets in a barley ear, thereby significantly reducing its yield. The more noticeable response of barley to the inoculation, compared to spring wheat, may be attributed to a less developed root system of barley and, therefore, to a larger "compensatory effect" of inoculation.

\subsection{Effects on physiology and productivity of plants}

Stimulation of the root system with the bacteria increased the feeding area and, therefore, the total content of nitrogen and phosphorus in the green mass of both tested crops. Improvement of nitrogen and phosphorus nutrition of the plants under the influence of inoculation is noted by many researchers $[17,18]$. In our studies, the complex inoculation of spring wheat increased the total nitrogen content by $10-12 \%$ and the total phosphorus content by $50-54 \%$ on average over all years. The inoculation of barley contributed to a significant increase in the total nitrogen (24-30\%) and phosphorus (11-13\%).

Photosynthesis processes, along with mineral nutrition processes, are known to be decisive factors of grain maturing. At the same time, optimization of mineral nutrition is known to have a positive effect on photosynthetic activity of plants [19]. It is probably for this reason that the inoculation has also contributed to a significant increase of photosynthetic pigments in wheat and barley leaves. The inoculation of wheat with the Bacillus cereus monoculture contributed to a significant average increase in chlorophyll $a$ and $b$ contents in the leaves: $19-20 \%$ and $21-23 \%$, respectively. Application of the Pseudomonas sp. monoculture (PhS1 and GS4 strains) increased the chlorophyll $a$ and $b$ contents in the leaves by $22-27 \%$ and $31-33 \%$, respectively. The greatest effect was demonstrated by the PhS1 strain, which was capable of phosphate mobilization. The use of the bacteria in combination with bacilli did not provide a significant additional effect: an average increase in the contents of chlorophyll $a$ and $b$ was $28-31 \%$ and $32-34 \%$ over the years.

The assessment of presowing seed treatment of spring wheat and barley conducted from 2011 to 2015 showed that, with rare exceptions, the inoculation in the climatic conditions of Western Siberia increased the grain yield of spring wheat by $8-37 \%$ compared to the control variant. It is equivalent to $0.2-1.0$ tonnes per ha. The greatest increase was provided by the inoculation of wheat with a monoculture of Pseudomonas strains. In different years, the inoculation of barley increased the grain yield by $8-26 \%$, which was equivalent to $0.3-1.8$ tonnes per ha. The complex inoculation demonstrated the best results (Table 1).

In addition to the increased yield of the grain crops per hectare, the inoculation contributed to improving its quality. For example, in different years, the inoculation of spring wheat contributed to an increase in the protein content in the grain from $15.3-17.4 \%$ in the control variant to $16.5-17.7 \%$ in the experimental variants (Table $\mathbf{1}$ ).

The analysis of the yield structure shows that the bacteria contribute, first of all, to an increase in the productive tillering capacity and grain content. For example, on average over the years, 


\begin{tabular}{|c|c|c|c|c|c|c|c|c|}
\hline \multirow[t]{3}{*}{ Variant } & \multicolumn{8}{|c|}{ Research period, year } \\
\hline & \multicolumn{2}{|l|}{2011} & \multirow{2}{*}{$\begin{array}{l}2012 \\
\begin{array}{l}\text { Grain yield } \\
\text { (ton/ha) }\end{array} \\
\end{array}$} & \multirow{2}{*}{$\begin{array}{l}2013 \\
\begin{array}{l}\text { Grain yield } \\
\text { (ton/ha) }\end{array} \\
\end{array}$} & \multicolumn{2}{|l|}{2014} & \multicolumn{2}{|l|}{2015} \\
\hline & $\begin{array}{l}\text { Grain yielc } \\
\text { (ton } / \text { ha) }\end{array}$ & $\begin{array}{l}\text { Protein } \\
\text { content (\%) }\end{array}$ & & & $\begin{array}{l}\text { Grain yield } \\
\text { (ton/ha) }\end{array}$ & $\begin{array}{l}\text { Protein } \\
\text { content (\%) }\end{array}$ & $\begin{array}{l}\text { Grain yield } \\
\text { (ton/ha) }\end{array}$ & $\begin{array}{l}\text { Protein content } \\
(\%)\end{array}$ \\
\hline \multicolumn{9}{|l|}{ Wheat } \\
\hline Control (water treatment) & $2.7 \pm 0.1$ & $16.2 \pm 1.2$ & $0.9 \pm 0.04$ & $2.5 \pm 0.1$ & $3.4 \pm 0.2$ & $15.3 \pm 1.4$ & $2.3 \pm 0.1$ & $17.4 \pm 1.1$ \\
\hline $\begin{array}{l}\text { Bacterization of Bacillus } \\
\text { cereus }\end{array}$ & $3.0 \pm 0.1$ & $16.5 \pm 1.2$ & $1.2 \pm 0.1$ & - & - & - & - & - \\
\hline Bacterization of Ps.sp. GS4 & $3.7 \pm 0.2^{*}$ & $16.6 \pm 1.3$ & $1.0 \pm 0.1$ & $2.7 \pm 0.3$ & - & - & - & - \\
\hline Bacterization of Ps.sp. PhS1 & - & - & $1.2 \pm 0.1$ & $2.8 \pm 0.3$ & $3.6 \pm 0.1$ & $16.8 \pm 0.9$ & $3.3 \pm 0.2^{*}$ & $17.5 \pm 0.8$ \\
\hline $\begin{array}{l}\text { Complex bacterization } \\
\text { (mixed culture) }\end{array}$ & $3.1 \pm 0.1^{*}$ & $16.9 \pm 1.3$ & - & $3.2 \pm 0.2^{*}$ & $3.4 \pm 0.03$ & $17.0 \pm 1.2$ & $2.5 \pm 0.2$ & $17.7 \pm 0.9$ \\
\hline \multicolumn{9}{|l|}{ Barley } \\
\hline Control (water treatment) & $8.1 \pm 0.4$ & $8.2 \pm 0.5$ & $1.5 \pm 0.2$ & $3.9 \pm 0.3$ & $7.5 \pm 0.2$ & $11.8 \pm 1.1$ & $3.9 \pm 0.2$ & $12.5 \pm 0.7$ \\
\hline $\begin{array}{l}\text { Bacterization of Bacillus } \\
\text { cereus }\end{array}$ & $9.5 \pm 0.3^{*}$ & $9.3 \pm 0.3^{*}$ & $2.4 \pm 0.3$ & - & - & - & - & - \\
\hline Bacterization of Ps.sp. GS4 & $9.7 \pm 0.3^{*}$ & $9.1 \pm 0.2$ & $2.4 \pm 0.2$ & $4.2 \pm 0.2$ & - & - & - & - \\
\hline Bacterization of Ps.sp. PhS1 & - & - & $2.5 \pm 0.1$ & $4.3 \pm 0.3$ & $7.8 \pm 0.3$ & $11.5 \pm 1.0$ & $4.4 \pm 0.3$ & $12.6 \pm 0.6$ \\
\hline $\begin{array}{l}\text { Complex bacterization } \\
\text { (mixed culture) }\end{array}$ & $9.9 \pm 0.4^{*}$ & $9.4 \pm 0.2^{*}$ & - & $4.3 \pm 0.1$ & $8.0 \pm 0.3^{*}$ & $11.5 \pm 1.1$ & $4.9 \pm 0.2^{*}$ & $12.7 \pm 0.7$ \\
\hline
\end{tabular}

*The difference with the control by the Mann-Whitney test is reliable for $\mathrm{p}<0.5$.

Table 1. Effect of presowing treatment of spring wheat and barley seeds with bacterial strains on yield and grain quality. 
the productive tillering capacity of spring wheat increased from 1.04-1.37 in the control variant to 1.12-1.55 in the inoculated variants. The grain content of spring wheat increased from 23-26 grains per year in the control variant to 24.4-32.4 grains per year in the experimental variants. The inoculation with the monoculture of phosphate-mobilizing strain Ps.spPhS1 or the complex with these bacteria turned out to be the most effective solution. Weight of 1000 grains, another important indicator of the yield structure, also slightly increased under the influence of inoculation - from 27.9-34.0 $\mathrm{g}$ in the control variant to 29.1-35.4 $\mathrm{g}$ in the experimental variants.

\subsection{Effects on the resistance of plants to pathogens}

One of the most important factors that makes a significant contribution to grain crop yield is the development of diseases on plants, including root rots. Five-year field tests showed that the inoculation enhanced the resistance of spring wheat and barley plants to agents of root rots. Except for the dry year of 2012, the prevalence of the disease in spring wheat plants was significantly reduced - from $18.1-61.1 \%$ in the control variant to $6.4-50.2 \%$ in the inoculated variants. Severity of the disease was also significantly reduced in most cases. For example, in different years, the index of root rot development decreased from 18.2-23.0\% in the control variants to $13.2-15.8 \%$ in the inoculated variants (Table 2).

The capability of rhizobacteria to increase the resistance of plants to phytopathogens is widely discussed in the scientific literature. However, mechanisms responsible for increasing this resistance remain understudied. Most researchers have come to the conclusion that nonpathogenic rhizobacteria can activate resistance mechanisms of plants in the same way as phytopathogens, in particular through the synthesis of PR proteins, including peroxidase $[7,20,21]$.

To clarify the mechanism that induces the spring wheat resistance to the agent of Helminthosporium root rots under the influence of rhizobacteria, we studied the effect of inoculation of spring wheat seeds on the guaiacol-dependent peroxidase activity in the presence of artificial infection background. The main test objects were wheat plants (Triticum aestivum L., Iren variety, susceptible to root rots) and two Pseudomonas sp. (GS4 and PhS1) strains isolated from earthworm coprolites. These strains showed significant antifungal and growth-stimulating activities in laboratory conditions and confirmed this activity in field experiments [4].

It was no coincidence that microorganisms of the Pseudomonas genus were selected for inoculation. Researchers have paid particularly close attention to Pseudomonas. The capability of these bacteria to increase the resistance of a host plant to phytopathogens is demonstrated in studies by Choudhary et al. [22] Van Loon [23], and other researchers. This type of induced resistance is known as rhizobacteria-induced systemic resistance of plants [24].

Bacteria are known to have a positive effect only if they successfully colonize the rhizosphere $[22,25]$. The effectiveness of wheat inoculation in our model experiment was assessed in terms of decreased development and prevalence of root rot agents in variants with and without infection background. The prevalence of the disease in the experimental variant without infection background and inoculation was at the level of $26 \%$. In variants with artificial B. sorokiniana 


\begin{tabular}{|c|c|c|c|c|c|c|c|c|c|}
\hline \multirow[t]{3}{*}{ Variant } & \multicolumn{9}{|c|}{ Research period, year } \\
\hline & \multirow{2}{*}{$\begin{array}{l}2011 \\
\text { Prevalence } \\
\text { of the } \\
\text { disease (\%) }\end{array}$} & \multicolumn{2}{|l|}{2012} & \multicolumn{2}{|l|}{2013} & \multicolumn{2}{|l|}{2014} & \multicolumn{2}{|l|}{2015} \\
\hline & & $\begin{array}{l}\text { Prevalence } \\
\text { of the } \\
\text { disease }(\%)\end{array}$ & $\begin{array}{l}\text { Index of } \\
\text { disease } \\
\text { development } \\
(\%)\end{array}$ & $\begin{array}{l}\text { Prevalence } \\
\text { of the } \\
\text { disease }(\%)\end{array}$ & $\begin{array}{l}\text { Index of } \\
\text { disease } \\
\text { development } \\
(\%)\end{array}$ & $\begin{array}{l}\text { Prevalence } \\
\text { of the } \\
\text { disease } \\
(\%)\end{array}$ & $\begin{array}{l}\text { Index of } \\
\text { disease } \\
\text { development } \\
(\%)\end{array}$ & $\begin{array}{l}\text { Prevalence } \\
\text { of the } \\
\text { disease (\%) }\end{array}$ & $\begin{array}{l}\text { Index of disease } \\
\text { development }(\%)\end{array}$ \\
\hline \multicolumn{10}{|l|}{ Wheat } \\
\hline Control (water treatment) & $18.1 \pm 3.4$ & $53.1 \pm 10.7$ & $23.0 \pm 3.0$ & $51.7 \pm 3.6$ & $19.9 \pm 3.8$ & $56.4 \pm 10.5$ & $18.2 \pm 3.4$ & $61.1 \pm 17.4$ & $21.7 \pm 7.1$ \\
\hline Bacterization of Bacillus cereus & $14.3 \pm 1.2$ & $43.3 \pm 6.4$ & $21.7 \pm 3.9$ & - & - & - & - & - & - \\
\hline Bacterization of Ps.sp. GS4 & $6.4 \pm 0.8^{*}$ & $45.2 \pm 7.1$ & $14.7 \pm 2.9^{*}$ & $44.4 \pm 2.6^{*}$ & $15.8 \pm 3.1^{*}$ & - & - & - & - \\
\hline Bacterization of Ps.sp. PhS1 & - & $50.2 \pm 11.4$ & $21.1 \pm 2.1$ & $36.7 \pm 5.7^{*}$ & $13.2 \pm 2.6^{*}$ & $39.4 \pm 12.4$ & $13.9 \pm 1.7^{*}$ & $50.0 \pm 17.8$ & $15.8 \pm 3.3$ \\
\hline $\begin{array}{l}\text { Complex bacterization } \\
\text { (mixed culture) }\end{array}$ & $10.0 \pm 2.2^{*}$ & - & - & $38.3 \pm 6.7^{*}$ & $11.2 \pm 0.6^{*}$ & $47.2 \pm 9.8$ & $16.0 \pm 2.5$ & $26.6 \pm 15.8^{*}$ & $9.2 \pm 1.7^{*}$ \\
\hline \multicolumn{10}{|l|}{ Barley } \\
\hline Control (water treatment) & $13.9 \pm 1.7$ & $79.2 \pm 17.3$ & $45.5 \pm 6.1$ & $44.4 \pm 2.9$ & $14.7 \pm 2.6$ & $87.0 \pm 11.3$ & $41.2 \pm 9.7$ & $66.7 \pm 16.8$ & $28.3 \pm 2.7$ \\
\hline Bacterization of Bacillus cereus & $5.8 \pm 1.3^{*}$ & $71.5 \pm 10.7$ & $31.6 \pm 2.7^{*}$ & - & - & - & - & - & - \\
\hline Bacterization of Ps.sp. GS4 & $11.7 \pm 2.7$ & $73.7 \pm 11.0$ & $33.7 \pm 2.3^{*}$ & $24.4 \pm 8.07^{*}$ & $8.3 \pm 2.5^{*}$ & - & - & - & - \\
\hline Bacterization of Ps. sp. PhS1 & - & $61.9 \pm 8.8$ & $30.6 \pm 1.8^{*}$ & - & - & $73.1 \pm 11.6$ & $34.3 \pm 5.1^{*}$ & $46.6 \pm 7.8^{*}$ & $14.2 \pm 2.0^{*}$ \\
\hline $\begin{array}{l}\text { Complex bacterization } \\
\text { (mixed culture) }\end{array}$ & $6.5 \pm 1.9^{*}$ & - & - & $41.0 \pm 7.8$ & $13.3 \pm 2.5$ & $71 \pm 6.7$ & $30.1 \pm 3.4^{*}$ & $57.7 \pm 12.6$ & $20.8 \pm 3.7^{*}$ \\
\hline
\end{tabular}

*The difference with the control by the Mann-Whitney test is reliable for $\mathrm{p}<0.5$.

Table 2. Influence of presowing treatment of spring wheat and barley seeds with bacterial strains on the infection of plants with root rot. 
infection background, there was a significant increase in the number of wheat seedlings with signs of the disease. This finding demonstrates the effectiveness of the infection background method. In case of inoculation, we observed 1.4- to 2.5-fold decrease in the prevalence of disease and disease index compared to the control variant with and without infection background, with the greatest decrease demonstrated by the inoculation with the Pseudomonas sp. PhS1 bacteria. The same strain provided the maximum (2- to 4-fold) decrease in the disease index compared to the control variant with and without infection load (Figure 1).

\subsection{Effects on peroxidase activity in model experiment with an artificial infectious load}

According to some authors, the peroxidase activity can be used as a marker of plant resistance to phytopathogens [26, 27]. Since roots (rather than stems and leaves) are the first to contact the phytopathogenic fungus when the plants are infected with root rots, a separate assessment of oxidative stress enzyme activity in roots and aerial parts of plants is a matter of scientific interest.

The results of the peroxidase activity analysis showed that, in general, the inoculation significantly increased the enzyme activity in wheat leaves, both with and without the B. sorokiniana phytopathogen in the system. The maximum increase in the peroxidase activity was induced by the Pseudomonas sp. PhS1 strain in the variants without infection load and by the Pseudomonas sp. GS4 strain with infection load. Similar effects were found by Manikandan et al. [28] after the treatment of tomato plants with a liquid Ps. fluorescence Pf1 culture, which significantly increased peroxidase and polyphenol oxidase activities, and inhibited the development of Fusarium oxysporum f. sp. lycopersici in plant roots. Garcia-Cristobal et al. [25] demonstrated

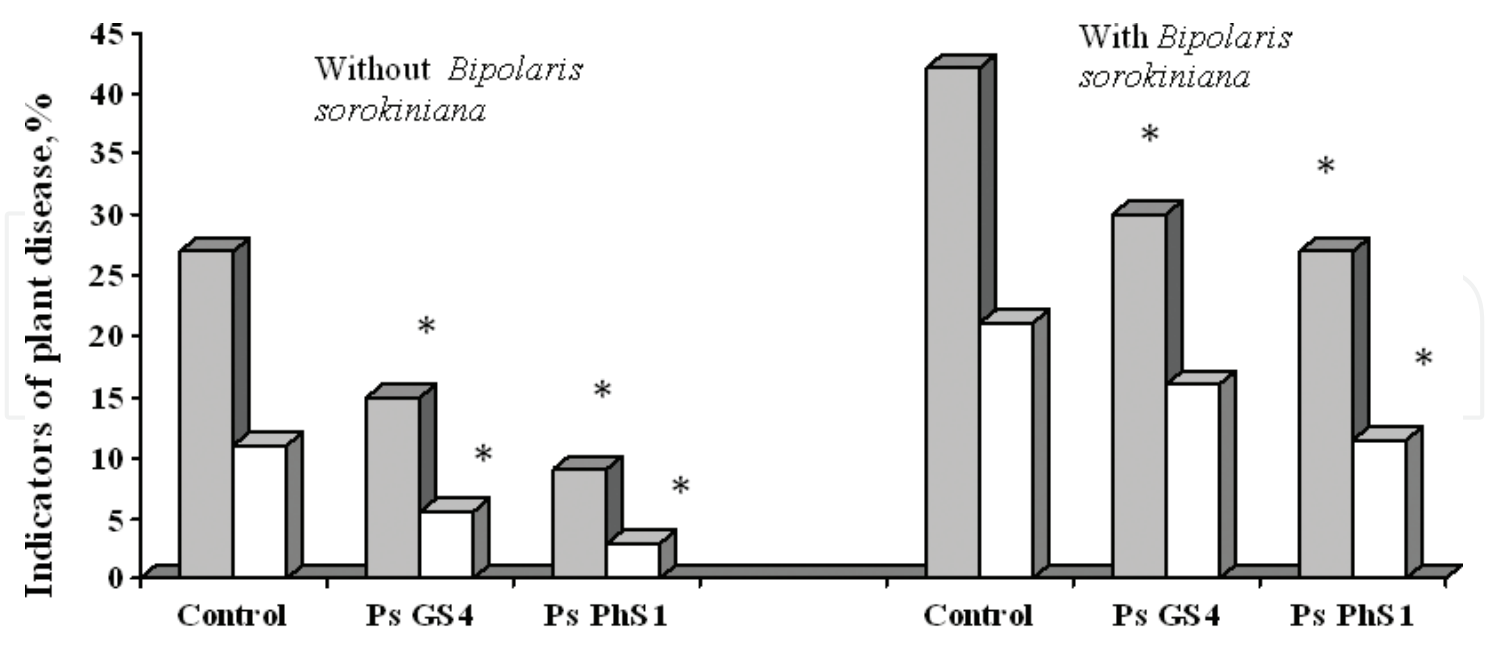

$\square$ Prevalence of the disease $\square$ Disease Index

Figure 1. The prevalence of root rot and the disease index in a model experiment with the bacterization of wheat seeds with and without Bipolaris sorokiniana. Control-without bacterization; Ps.sp.GS4-bacterization of Pseudomonas sp. strain GS4; Ps.sp.PhS1-bacterization of Pseudomonas sp. strain PhS1, * - statistically significant difference with the corresponding control by the Mann-Whitney test $(\mathrm{p}<0.05)$. 
an increase in germination and resistance of rice plants to Xanthomonas campestris after seed treatment with the Bacillus sp. L81 strain and, at the same time, increased peroxidase activity as early as the first 48 hours after the treatment.

In our experiment, wheat plants responded to the infection with B. sorokiniana by significantly $(11 \%)$ increasing the peroxidase activity in their roots (Figure 2 ). The analysis of the enzyme response to plant inoculation revealed an interesting relationship: the response of the peroxidase activity to seed inoculation without a phytopathogen was insignificant ( $4 \%$ increase in the enzyme activity when using the Pseudomonas sp. PhS1 strain). The inoculation with $B$. sorokiniana increased the enzyme activity in plant roots by $14 \%$ when the seeds were treated with the Pseudomonas sp. GS4 strain and by more than $40 \%$ when the Pseudomonas sp. PhS1 was used (Figure 2).

A comparison of the peroxidase activity in leaves and roots of uninfected and infected plants showed that the free peroxidase activity in the plant roots was, respectively, 60 and 23\% higher than that in the leaves. At the same time, the response of enzyme systems to the inoculation in the presence of the causing agent was found to be much higher in the roots than the response of free peroxidase in the leaves. For example, the inoculation of wheat seeds with Pseudomonas increased the peroxidase activity by $29-58 \%$ in the roots and only by $4-20 \%$ in the leaves of the infected plants (Figure 2). This pattern was not identified in the uninfected plants.

The correlation analysis of the data obtained in the variants without a causing agent B. sorokiniana revealed a direct relationship between the peroxidase activity in the roots and tissues of wheat leaves, as well as a feedback between the peroxidase activity in the leaves and roots of wheat, disease index, and prevalence of the disease, that is, the parameters reflecting the

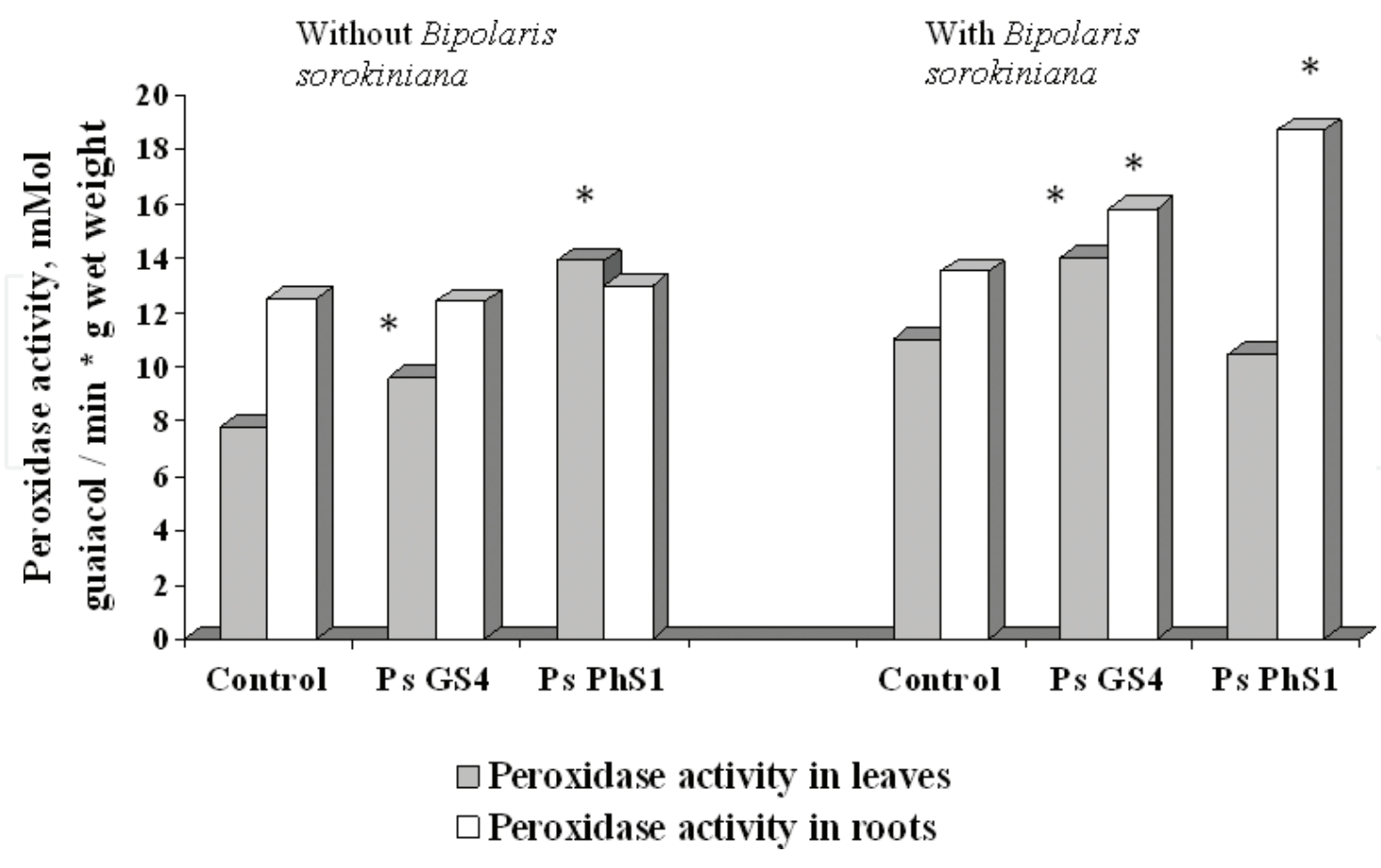

Figure 2. Peroxidase activity in wheat leaves and roots in a model experiment with seed bacterization with and without Bipolaris sorokiniana. 
susceptibility of plants to root rots $(r=-0.833$ and -0.889 , respectively). These findings suggest that, with increasing peroxidase activity in plant tissues, the resistance to root rot causing agents increases significantly. This confirms the available data on a relationship of peroxidase activity and content with the plant resistance to phytopathogens [25, 28-30].

The $B$. sorokiniana infection background significantly changed the relationship between the peroxidase activity in roots and tissues of wheat leaves. The coefficient of correlation between these parameters became negative and statistically insignificant $(r=-0.330)$. This may be associated with a change in the plant's strategy in response to its contact with the phytopathogen: the peroxidase activity significantly increases in the roots and decreases in the leaf tissues. The lignification catalyzed by peroxidase is known to play an extremely important role in protecting plant tissues from phytopathogens. The resulting mechanical barrier limits the water exchange and supply of nutrients to the zone of penetration of pathogenic microorganisms $[22,31]$. Since the root rot causing agents, including $B$. sorokiniana, penetrate a plant through its roots and root neck, similar rearrangement of the activity can play a decisive role in inducing the systemic resistance of plants to this group of diseases.

Thus, the experimental findings suggest that there is an inverse relationship between the peroxidase activity in wheat tissues and damage of plants caused by root rot agents, and that the response of peroxidase enzymes to plant inoculation is a meaningful indicator that can be used to assess the potential of a particular strain as a biological agent for protecting spring wheat.

\section{Conclusion}

The results of a series of field tests in the climatic conditions of Western Siberia showed that the inoculation of spring wheat seeds with three bacterial strains isolated from earthworm coprolites increased the grain yield of spring wheat by $0.2-1.0 \mathrm{t} \mathrm{ha}^{-1}$. In different years, the inoculation of barley increased the grain yield by $0.3-1.8 \mathrm{t} \mathrm{ha}^{-1}$. In addition, the inoculation contributed to improving grain quality where the inoculation of spring wheat contributed to an increase in the protein content in the grain from 15.3-17.4\% in the control variant to $16.5-17.7 \%$ in the variants with bacterization. Besides, field experiments showed that the grain bacteria inoculation enhanced the resistance of spring wheat and barley plants to root rots. For example, the prevalence of the disease in spring wheat plants subjected to bacterization was reduced from 18.1-61.1 to $6.4-50.2 \%$. Severity of the disease was also significantly reduced in most cases where the index of root rot development decreased from 18.2-23.0\% in the control variants to $13.2-15.8 \%$ in the inoculated variants. The results of model experiment clarified a number of mechanisms for increasing the plants' resistance to root rots under the influence of rhizobacteria in the presence of artificial infection load (Bipolaris sorokiniana (Sacc.) Shoemaker). The experimental findings suggest that there is an inverse relationship between the peroxidase activity in wheat tissues and damage of plants caused by root rot agents, and that the response of peroxidase enzymes to plant inoculation is a meaningful indicator that can be used to assess the potential of a particular strain as a biological agent for protecting spring wheat. 


\section{Author details}

Natalia Tereshchenko ${ }^{1,2 *}$, Elena Akimova ${ }^{1}$, Oksana Minaeva ${ }^{1}$, Alexandra Kravets ${ }^{2}$ and Tatyana Zyubanova ${ }^{2}$

${ }^{*}$ Address all correspondence to: ternat@mail.ru

1 Department of Ecology, Nature Management and Environmental Engineering, Tomsk State University, Tomsk, Russia

2 Siberian Federal Scientific Center of Agrobiotechnologies, Russian Academy of Sciences, Tomsk, Russia

\section{References}

[1] Kozhemyakov AP, Belobrova SN, Orlova AG. Creating and analyzing a database on the efficiency of microbial preparations of complex action. Sel'skohozyaistvennaya biologiya (Agricultural Biology). 2011;3:112-115

[2] Chulkina VA, Konyaeva NM, Kuznetsova TT. Bor'ba s boleznyami sel'skokhozyaistvennykh kul'tur v Sibiri. Moscow: Rossel'hozizdat; 1987. p. 252

[3] Toropova EYu, Vorob'eva IG, Chulkina VA, Marmuleva EY. About a role of biological diversity in the phytosanitary optimization of agrarian landscapes. Sel'skohozyaistvennaya biologiya (Agricultural Biology). 2013;3:12-17

[4] Tereshchenko NN, Kravets AV, Akimova EE, Minayeva OM, Zotikova AP. Effectiveness of applying microorganisms isolated from earthworm coprolites in increasing yielding capacity of grain crops. Siberian Herald of Agricultural Science. 2013;5:10-17

[5] Compant S, Duffy B, Nowak J, Clement C, Barka EA. Use of plant growth-promoting bacteria for biocontrol of plant diseases: Principles, mechanisms of action, and future prospects. Applied and Environmental Microbiology. 2005;71(9):4951-4959. DOI: 10.1128/ AEM.71.9.4951-4959.2005

[6] Raupach GS, Kloepper JW. Mixtures of plant growth-promoting rhizobacteria enhance biological control of multiple cucumber pathogens. Phytopathology. 1998;88(11):1158-1164. DOI: 10.1094/PHYTO.1998.88.11.1158

[7] Johnson KB. Pathogen refuge: A key to understanding biological control. Annual Review of Phytopathology. 2010;48:141-160. DOI: 10.1146/annurev.phyto.112408.132643

[8] Gupta G, Parihar SS, Ahirwar NK, Snehi SK, Singh V. Plant growth promoting rhizobacteria (PGPR): Current and future prospects for development of sustainable agriculture. Journal of Microbial and Biochemical Technology. 2015;7:096-102. DOI: 10.4172/1948-5948.1000188 
[9] Berg G, Fritze A, Roskot N, Smalla K. Evaluation of potential biocontrol rhizobacteria from different host plants of Verticillium dahlia Kleb. Journal of Applied Microbiology. 2001;91:963-971. DOI: 10.1046/j.1365-2672.2001.01462.x

[10] Georgakopoulos DG, Fiddaman P, Leifert C, Malathrakis NE. Biological control of cucumber and sugar beet damping-off caused by Pythium ultimum with bacterial and fungal antagonists. Journal of Applied Microbiology. 2002;92:1078-1086. DOI: 10.1046/ j.1365-2672.2002.01658.x

[11] Smyth EM, McCarthy J, Nevin R, Khan MR, Dow JM, O'Gara F, et al. In vitro analyses are not reliable predictors of the plant growth promotion capability of bacteria; a Pseudomonas fluorescens strain that promotes the growth and yield of wheat. Journal of Applied Microbiology. 2011;111(3):683-692. DOI: 10.1111/j.1365-2672.2011.05079.x

[12] Minaeva OM, Akimova EE. Effectiveness of applying bacteria Pseudomonas sp., strain B-6798, for anti-phytopathogenic protection of crops in Western Siberia. Journal of Biology. Tomsk State University. 2013;3(23):19-37

[13] Shlyk AA. Opredelenie khlorofillov i karotinoidov v ekstraktakh zelenykh list'ev. Biokhimicheskie metody v fiziologii rasteniy. M.: Nauka; 1971. pp. 154-170

[14] Cooke BM. Disease assessment and yield loss. In: Cooke BM, Jone DG, Kaye B, editors. The Epidemiology of Plant Diseases. 2nd ed. Dorchert: Springer; 2006. pp. 43-80

[15] BoyarkinAN. Bystryjmetodopredeleniyaaktivnostiperoksidazy. Biohimiya (Biochemistry). 1951;16(4):352

[16] Dodd IC, Zinovkina NY, Safronova VI, Belimov AA. Rhizobacterial mediation of plant hormone status. Annals of Applied Biology. 2010;157:361-379

[17] Khamova OF, Ledovsky EN, Tukmacheva EV, Shuliko NN. Influence of bacterial fertilizer on the biological activity of leached chernozem and cereal crops productivity. Vestnik Omskogo gosudarstvennogo agrarnogo universiteta (Bulletin of Omsk State Agrarian University). 2016;3(23):44-48

[18] Vacheron J, Desbrosses G, Bouffaud ML. Prigent-combaret plant growth-promoting rhizobacteria and root system functioning. Frontiers in Plant Science. 2013;4:356-361

[19] Priadkina GA, Stasik OO, Mikhalskaya LN, Shvartau VV. A relationship between chlorophyll photosynthetic potential and yield in winter wheat (Triticum aestivum L.) at elevated temperatures. Sel'skohozyaistvennaya biologiya (Agricultural Biology). 2014;5:88-95

[20] Zaharenko VA. Biopesticidyisredstvazashchityrastenij s nebiocidnojaktivnost'yu v integrirovannomupravleniifitosanitarnymsostoyaniemzernovyhagroehkosistem. Agrohimiya (Agrochemistry). 2015;6:64-76

[21] Schisler DA, Slininger PJ, Bothast RJ. Effects of antagonist cell concentration and two strain mixtures on biological control of Fusarium dry rot of potatoes. Phytopathology. 1997;87:177-183. DOI: 10.1094/PHYTO.1997.87.2.177 
[22] Choudhary DK, Kasotia A, Jain S, Vaishnav A, Kumari S, Sharma KP, et al. Bacterialmediated tolerance and resistance to plants under abiotic and biotic stresses. Journal of Plant Growth Regulation. 2016;35:276-300. DOI: 10.1007/s00344-015-9521-x

[23] Van Loon LC. Plant responses to plant growth-promoting rhizobacteria. European Journal of Plant Pathology. 2007;119:243-254. DOI: 10.1007/s10658-007-9165-1

[24] Jankiewicz U, Kotonowicz M. The involvement of Pseudomonas bacteria in induced systemic resistance in plants (review). Prikladnayabiohimiyaimikrobiologiya (Applied Biochemistry and Microbiology). 2012;48(3):276-281

[25] Garcia-Cristobal J, Garcia-Villaraco A, Ramos B, Gutierrez-Manero J, Lucas JA. Priming of pathogenesis related-proteins and enzymes related to oxidative stress by plant growth promoting rhizobacteria on rice plants upon abiotic and biotic stress challenge. Journal of Plant Physiology. 2015;188:72-79. DOI: 10.1016/j.jplph.2015.09.011

[26] Van Lelyveld LJ, van Vuuren SP. Peroxidase activity as a marker in greening disease of citrus for assessment of tolerance and susceptibility. Journal of Phytopathology. 1988;121:357-362. DOI: 10.1111/j.1439-0434.1988.tb00979.x

[27] Reuveni R. Biochemical markers for disease resistance. In: Singh RP, Singh US, editors. Molecular Methods in Plant Pathology. Boca Ratton, FL, USA: Lewis Publisher; 1995. pp. 99-114

[28] Manikandan R, Raguchander T. Fusarium oxysporum f. sp. lycopersici retardation through induction of defensive response in tomato plants using a liquid formulation of Pseudomonas fluorescens (Pf1). European Journal of Plant Pathology. 2014;140:469-480. DOI: 10.1007/s10658-014-0481-y

[29] Pieterse CMJ, Zamioudis C, Berendsen RL, Weller DM, Van Wees SCM, Bakker PAHM. Induced systemic resistance by beneficial microbes. Annual Reviews of Phytopathology. 2014;52:347-375. DOI: 10.1146/annurev-phyto-082712-102340

[30] Jain A, Das S. Insight into the interaction between plants and associated fluorescent Pseudomonas spp. International Journal of Agronomy. 2016. 4269010, 8 pages $10.1155 / 2016 / 4269010$

[31] Maksimov IV, Valeev AS, Cherepanova EA, Yarullina LG. Hydrogen peroxide production in wheat leaves infected with the fungus Septoria nodorum Berk. Strains with different virulence. Applied Biochemistry and Microbiology. 2009:45(4):433-438. DOI: 10.1134/S0003683809040152 

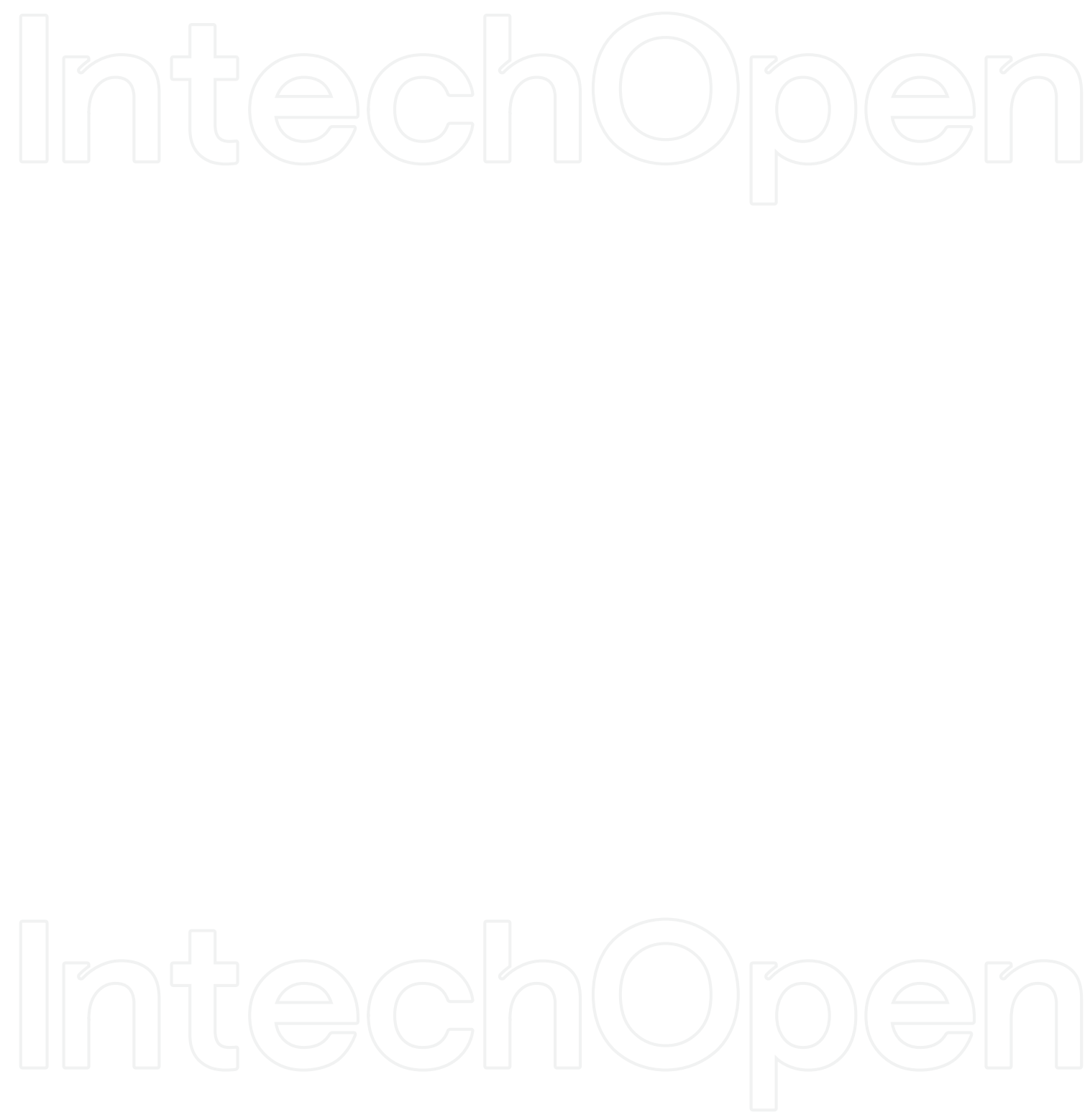